FAIXA PIANCÓ-ALTO BRÍGIDA: TERRENOS TECTONOESTRATIGRÁFICOS SOB REGIMES METAMÓRFICOS E DEFORMACIONAIS CONTRASTANTES

Sheila Maria Bretas Bittar

Orientador: Prof. Dr. Mario da Costa Campos Neto

TESE DE DOUTORAMENTO

Programa de Pós-Graduação em Geoquímica e Geotecônica

SÃO PAULO

1998 
UNIVERSIDADE DE SÃO PAULO

INSTITUTO DE GEOCIENNCIAS

\title{
FAIXA PIANCÓ-ALTO BRÍGIDA: TERRENOS TECTONO- ESTRATIGRÁFICOS SOB REGIMES METAMÓRFICOS E DEFORMACIONAIS CONTRASTANTES
}

\author{
SHEILA MARIA BRETAS BITTAR
}

Orientador: Prof. Dr. Mario da Costa Campos Neto

TESE DE DOUTORAMENTO

COMISSÃO JULGADORA

Nome

Assinatura

Presidente: Prof. Dr. Mario da Costa Campos Neto

Examinadores: Prof. Dr. Antenor Zanardo

Prof. Dr. Benjamim Bley de Brito Neves

Prof. Dr. Carlos José Archanjo

Prof Dr $^{\mathrm{a} \cdot}$ Ignez de Pinho Guimarães

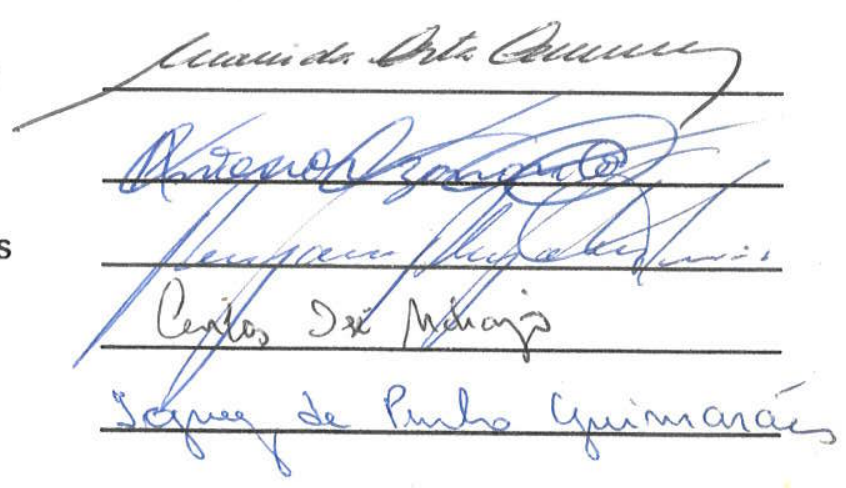

SÃO PAULO

1999 


\title{
UNIVERSIDADE DE SÃO PAULO INSTITUTO DE GEOCIEENCIAS
}

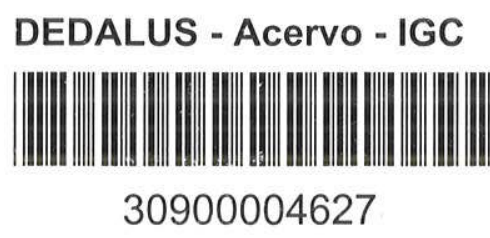

FAIXA PIANCÓ-ALTO BRÍGIDA: TERRENOS TECTONOESTRATIGRÁFICOS SOB REGIMES METAMÓRFICOS E DEFORMACIONAIS CONTRASTANTES

\author{
Sheila Maria Bretas Bittar
}

Orientador: Prof. Dr. Mario da Costa Campos Neto

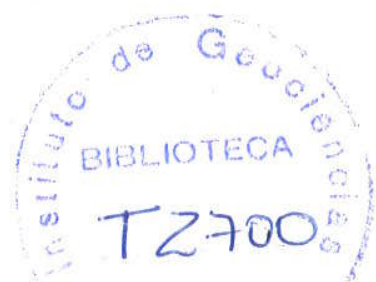

TESE DE DOUTORAMENTO

Programa de Pós-Graduação em Geoquímica e Geotecônica

SÃO PAULO

1998 
PARA

MARCOS, LUCAS E NINA 
FAIXA PIANCÓ-ALTO BRIGIDA: TERRENOS TECTONO-ESTRATIGRÁFICOS SOB REGIMES METAMÓRFICOS E DEFORMACIONAIS CONTRASTANTES

\section{SUMÁRIO}

I. INTRODUÇÃO

1.1 Localização, Acessos e Aspectos Físicos 1

1.2 Objetivos

1.3 Métodos 4

1.4 Trabalhos Anteriores $\quad 5$

II. COMPARTIMENTAÇÃO ESTRATIGRÁFIACA 20

II.1 Complexo Serra Talhada $\quad 22$

II.2 Xistos Sertânia $\quad 26$

II.3 Complexo Riacho Gravatá $\quad 26$

Il.3.1 Amêndoa Serra da Pinheira $\quad 27$

II.3.2 Amêndoa Macacos-Piaus $\quad 34$

II.3.3 Amêndoa Mocambo 36

11.4 Complexo Cachoeirinha $\quad 40$

II.4.1 Sequência Santana dos Garrotes $\quad 41$

II.4.2 Sequência Piancó $\quad 42$

II. 5 Sequência Serra do Olho D’Água 44

II.5.1 Litofácies Conglomerático 46

II.5.2 Litofácies Arenoso e Pelítico-Arenoso 48

III. SUITES PLUTÓNICAS 49

III.1 Suítes Plutônicas Brasilianas $\quad 49$

III.1.1 Granitos tipo Conceição 49

III.1.2 Granitos tipo Itaporanga $\quad 52$

III.1.3 Granitos tipo Catingueira/Triunfo $\quad 55$

III.1.4 Gabro tipo Taperoá $\quad 56$

III.1.5 Granitos tipo S $\quad 56$

III.2 Ortognaisses Cariris Velhos $\quad 57$

IV. METAMORFISMO

IV.1 Microestruturas e Texturas $\quad 58$

IV.2 Química Mineral $\quad 65$

IV.2.1 Química Mineral dos Metassedimentos $\quad 65$

IV.2.2 Química Mineral das Metabásicas $\quad 74$

IV.3 Geotermometria e Geobarometria .83

IV.3.1 Revisão dos Geotermômetros e Geobarômetros Aplicados 83

IV.4 Consideraçōes $\quad 94$

V. GEOLOGIA ESTRUTURAL

V.1 Organização e Cronologia das Estruturas 98

V.2 Domínio Estrutural Serra da Pinheira 103 
V.3 Domínio Estrutural Serra do Mocambo 105

V.4 Domínio Estrutural Macacos-Piaus $\quad 105$

$\begin{array}{ll}\text { V.5 Domínio Estrutural Serra Talhada } & 108\end{array}$

V.6 Domínio Estrutural Santana dos Garrotes $\quad 109$

V.7 Domínio Estrutural Piancó 111

V.8 Domínio Estrutural Serra do Olho D’Água 111

$\begin{array}{ll}\text { VI. CONCLUSÖES } & 113\end{array}$

$\begin{array}{ll}\text { VII. REFERENCIAS BIBLIOGRÁFICAS } & 118\end{array}$

\section{ANEXOS}

Mapa Geológico Simplificado da Faixa Piancó-Alto Brígida na Área de Serra Talhada-PiancóItaporanga (anexo 1)

Perfis Geológicos Estruturais da Área Serra Talhada-Piancó-Itaporanga (anexos 2, 3 e 4) 


\section{INDICE DAS FIGURAS}

Fig. 1) Mapa de acessos à área do presente trabalho, com a localização da área estudada. 1

Fig. 2) Esboço geotectônico do Domínio Tectônico Rio Pajeú e adjacências.

Fig.3) Esboço geológico localizando os terrenos tectono-estratigráficos da Faixa Piancó-Alto Brígida.

Fig. 4) Coluna estratigráfica do Complexo Riacho Gravatá na Amêndoa Serra da Pinheira. 34

Fig. 5) Coluna estratigráfica do Complexo Riacho Gravatá na Amêndoa Serra do Mocambo. 39

Fig. 6) Coluna estratigráfica da Sequência Deposicional Serra do Olho D'Água.

Fig. 7) Esboço geológico localizando as suítes plutônicas observadas na área.

Fig. 7) Esboço geológico localizando as suítes plutônicas observadas na área.

Fig. 9) Representação gráfica das biotitas analisadas no presente trabalho.

Fig. 10) Representação dos feldspatos analisados em metassedimentos no diagrama AlbitaOrtoclásio-Anortita.

Fig. 11) Representaçăo das granadas em metassedimentos da área do presente nos diagramas Almandina-Piropo-Espersartita e Almandina-Piropo-Grossulária.

Fig. 12) Classificação das micas brancas, segundo Deer et al (1978).

Fig. 13) Representaçăo dos feidspatos das metabásicas do Complexo Riacho Gravatá no diagrama Albita-Ortoclásio-Anortita.

Fig 14) Classificação dos anfibólios dos Complexo Riacho Gravatá (Leake et al, 1997).

Fig 15) Anfibólios do Complexo Riacho Gravatá plotados nos gráfico AllV $x(\mathrm{Na}+\mathrm{K}) \mathrm{A}(\mathrm{A})$ e AllV $\times$ Ti (B) e AllV X AIVI(C).

Fig. 16) Representação das granadas em metabásicas nos diagramas Almandina-PiropoEspersartita e Almandina-Piropo-Grossulária.

Fig. 17) Gráfico $T \times P$ evidenciando o contraste metamórfico entre os distintos terrenos tectonoestratigráficos estudados.

Fig 18) Mapa simplificado mostrando os domínios estruturais, seus limites e as direção de transporte observadas nas foliações $\mathrm{S} 2$ e S3.

Fig. 19) Estereograma dos elementos estruturais associados a F2 e F3, do domínio antiformal Serra Talhada, obtidos no perfil homônimo

Fig. 20) Estereogramas dos elementos de F2 e F3, para o domínio Santana dos Garrotes nos perfis Macacos-Piaus (A) e Piancó-Tavares (B). 


\section{INDICE DE FOTOGRAFIAS}

Foto 1) Biotita-gnaisse bandado cinza mostrando niveis anfiboliticos (A) e migmatização. Observa-se em (B) o leucossoma cortando o bandamento do gnaisse. Ocorre ainda schilliren no mesossoma (C).

Foto 2) Hornblenda-biotita-gnaisse bandado migmatizado. Placas de hornblenda e biotita mais desenvolvidas são observadas no contato entre leucossoma e o gnaisse. Granito (diatexito) ocorre paralelo A direção da transcorrência (S3).

Foto 3) Xenólito (restito ?) da anfibolito em diatexito.

Foto 4 ) Augen-gnaisse em núcleo de dobra da terceira fase de deformação (D3) que dobra o biotita-gnaisse bandado e desenvolve no augen-gnaisse uma foliação $S 3$.

Foto 5) Diatexito gerado a partir de intensa migmatização dos gnaisses bandados.

Foto 6) Estrutura sedimentar do tipo cut-and-fill côncava para cima observada em quartzito laminado (A) sobreposto por quartzito médio com grânulo decrescência ascendente (B) do Complexo Riacho Gravatá na Amêndoa Serra do Mocambo. Observa-se veio de quartzo cortando as estruturas.

Foto 7) Estratificação cruzada unidirecional desenvolvida em quartzito fino laminado do Complexo Riacho Gravatá na Amêndoa Serra do Mocambo.

Foto 8) Waves ripples em quartzito fino laminado do Complexo Riacho Gravatá na Amêndoa Serra do Mocambo.

Foto 9) Aspecto do metaconglomerado polimítico da Sequência Serra do Olho D'Água. Observa-se seixo anguloso, com cerca de $15 \mathrm{~cm}$ de comprimento, de metarritimito envolto em matriz metagrauváquica e contendo foliação metamórfica pretérita.

Foto 10) Aspecto geral do metagonglomerado da Sequência Serra do Olho D'Água). Observar seixos angulosos de variadas litologias.

Foto 11) Granito tipo Conceição, localizado a sul de Santana dos Garrotes. Observa-se enclaves básicos ligeiramente alongados e orientados segundo a foliação magmática, dada pela orientação preferencial de fenocristais de feldspatos e minerais máficos.

Foto 12) Afloramento do granito Itaporanga, localizado a este da cidade homônima, mostrando cumulatos de fenocristais de K-feldspato.

Foto 13) Granito Itaporanga (mesmo afloramento da foto anterior) apresentando foliação magmática dada pele orientação preferencial de minerais máficos e de fenocristais de Kfeldspatos, nos quais pode-se observar estrutura de entelhamento sugerindo movimentação sinistral.

Foto 14) Batólito Tavares: observa-se fluxo magmático convectivo e cumulatos de feldspatos (A). 
Foto 15) Xenólito de ortognaisse Cariris Velhos, com textura milonítica, no granito tipo Itaporanga. Localização a norte da cidade de Tavares.

Foto 16) Granada-muscovita-clorita-biotita xisto quartzoso do Complexo Riacho Gravatá (Amêndoa Serra do Mocambo). Observa-se granada com Si ondulada, possiveimente um representando estágio precoce da crenulação D2, sem continuidade com $\$ 2$ externa.

Foto 17) Granada-muscovita-biotita xisto do Complexo Riacho Gravatá (Amêndoa Serra da Pinheira). Observa-se granada (GR) com foliação interna (Si) disrupta da foliação externa (S2), definida como uma clivagem de crenulação transposta. Observar muscovita $(M)$ e biotita $(B)$ pós-S2.

Foto 18) Muscovita-biotita xisto quartzoso do Complexo Riacho Gravatá (Amêndoa Serra da Pinheira), com foliação $S 2$ milonitica, com venulas de quartzo paralelas ao plano $S$, crenuladas por D3. ( $A$ - nicóis $X ; B$ - nicóis $/ /$ )

Foto 19) Muscovita-biotita xisto do Complexo Riacho Gravatá (Amêndoa Serra da Pinheira) mostrando foliação S2 transposta por S3 milonítica. (nicóis X)

Foto 20) Granada-muscovita-biotia gnaisse do Complexo Riacho Gravatá (Amêndoa MacacosPiaus). Observa-se porfiroclásto tardio de biotita apresentando kinks bands. (nicóis /I)

Foto 21) Muscovita-biotita xisto fino cinza do Complexo Cachoeirinha (Sequência Santana dos Garrotes), onde pode-se observar granada com foliação Si e foliação externa S2 desviando-se ao redor desta, e desenvolvendo sombra de pressão, local. (nicóis $/ /$ )

Foto 22) Granada-estaurolita-muscovita-biotita xisto do Complexo Cachoeirinha (Sequência Piancó). Observa-se estaurolita com foliação interna $\mathrm{Si}$, interpretada como foliação $\mathrm{S1}$, crenulada abertamente por S2; a foliação externa S2, representada por uma clivagem de crenulação, e charneiras relictas D2 locais. (nicóis II)

Foto 23) Corona de reação (textura quelifítica) envolvendo granada (GR), anfibólio (A) e plagiociásio $(P)$ em granada anfibolito do Complexo Serra da Pinheira, Amêndoa Serra da Pinheira-sul. (A - nicóis $X, B$ - nicóis $/ I$ )

Foto 24) Xisto cinza fino da Sequência Santana dos Garrotes, localizado a oeste de Lagoa do Arroz. Observa-se (A) dobras D4 com plano axial sub-horizontal, deformando o bandamento diferenciado $\$ 3$, que crenula a foliação $\$ 2$, observada em detalhe na fotografia (B) 103

Foto 25) Quartzito com mica verde da unidade $C$ do Complexo Riacho (a norte de Manaíra) onde pode-se observar foliação $\mathrm{S}-\mathrm{C}_{2}$ sub-horizontal.

Foto 26) Tremolita-clorita xisto da unidade A do Complexo Riacho Gravatá (Amêndoa Serra da Pinheira, a norte de Manaira), onde pode-se observar dobras em bainha na foliação S2 subhorizontal.

Foto 27) Granada-muscovita-biotita xisto mostrando foliação milonítica $S-C_{3}$, onde se observa vênulas de quartzo orientadas paralelas a direção $S$, e o truncamento da foliação por zonas de cisalhamentos tardias.

Foto 28 ) Foliação S2 preservada em anfibolito bandado. No nível menos competente S2 está transposta para S3 (A). Nestes locais são comuns dobras em bainhas (B). 
Foto 29) Dobra D3 com plano axial em leque. Observar charneiras reliquiares D2 isoclinais. Metarritimito da unidade E do Complexo Riacho Gravatá (Amêndoa Macacos-Piaus), localizado na parte norte do perfil homônimo.

Foto 30) Muscovita-biotita gnaisse da Sequência Piancó, localizado no flanco sul da antiforme, onde observa-se zonas de cisalhamentos desenvolvidas no plano axial de dobras D3. Nestes locais são comuns dobras redobradas e dobras em bainha. 


\section{LISTA DE TABELAS}

Tabela 1) Dados geocronológicos do embasamento na área do presente trabalho e proximidades.

Tabela 2) Dados geocronológicos das supracrustais da Faixa de Dobramentos Piancó-Alto Brigida, localizadas na área do presente trabalho.

Tabela 3) Dados geocronológicos dos granitóides da área do presente trabalho e adjacências, localizados a sul da ZC Serra do Cabocto.

Tabela 4) Dados geocronológicos dos granitóides da área do presente trabalho e adjacências, localizados a norte da ZC Serra do Caboclo.

Tabela 5) Dados geocronológicos dos ortognaisses Cariris Velhos na área do presente trabalho e adjacências.

Tabela 6) Paragêneses descritas na área estudada.

Tabela 7) Dados de química mineral das cloritas estudadas, calculadas com base em 14oxigênios com todo $\mathrm{Fe}=\mathrm{Fe}^{2+}$.

Tabela 8) Análise química de biotitas realizadas no presente trabalho, calculadas com base em 11-oxigênios com todo $\mathrm{Fe}=\mathrm{Fe}^{2+}$.

Tabela 9) Dados da química mineral dos feldspatos das rochas metassedimentares, calculados com base em 8-oxigênios comFe $=\mathrm{Fe}^{2+}$.

Tabela 10) Análise quimica de granadas em metassedimentos dos Complexo Riacho Gravatá, Cachoeirinha e Sertânia, na área do presente trabalho, calculados para 12-oxigênios, com todo $\mathrm{Fe}=\mathrm{Fe}^{2+}$.

Tabela 11) Análise química das micas brancas em metassedimentos dos complexos Riacho Gravatá, Cachoeirinha e Xistos Sertânia, calculados com base em 11-oxigênios com $\mathrm{Fe}=\mathrm{Fe}^{2+}$.

Tabela 12) Dados de química mineral de feldspatos em anfibolitos e granada-anfibolitos do Complexo Riacho Gravatá, calculados com base em 8-oxigênios com $\mathrm{Fe}=\mathrm{Fe}^{2+}$.

Tabela 13) Análise química em metabásicas do Complexo Riacho Gravatá, calculados com base em 23-oxigênios, com $\mathrm{Fe}=\mathrm{Fe}^{3+}$ médio.

Tabela 14) Análise química de granadas em granada-anfibolitos do Complexo Riacho Gravatá, calculados para 12-oxigênios, com todo $\mathrm{Fe}=\mathrm{Fe}^{2+}$.

Tabela 15) Dados de geotermometria e geobarometria. 


\section{RESUMO}

A Faixa Piancó Alto Brígida, localizada no Domínio Tectônico Rio Pajeú é constituída por distintos terrenos tectono-estratigráficos, desenvolvidos sob regimes metamórficos e deformacionais contrastantes, justapostos durante a Orogênese Brasiliana (750 a $580 \mathrm{Ma}$ ).

Dentro deste contexto são definidas as seguintes sequências estratigráficas: Complexo Serra Talhada, ortognaisses e migmatitos paleoproterozóicos, remobilizados no Brasiliano; Complexo Riacho Gravatá, sequência metavulcânossedimentar, desenvolvida em regime extensional crustal no Mesoproterozóico, que mostra caracteristicas de deposição plataformal e sopé de talude continental; Complexo Cachoeirinha, sequência metavulcânossedimentar neoproterozóica, com afinidade vulcânica de arco magmático; Sequência Serra do Olho D’Água, sequência sedimentar tipo molássa neoproterozóica superior; e Xistos Sertânia, sequência metavuicânossedimentar correlata ao Complexo Sertânia, de idade mesoproterozóica. Estas sequências possuem como traço comum de união, a foliação metamórfica principal gerada durante a segunda fase de deformação, originalmente subhorizontal.

Seis suites plutônicas distintas, sendo cinco delas Brasilianas (granitóides tipo Conceição, tipo Itaporanga, tipo Catingueira/Triunfo, tipo Taperoá e graniłos tipo S) e uma da idade Cariris Velhos (ortognaisses Cariris Velhos) foram identificadas na área em apreço.

A estruturação da Faixa Piancó-Alto Brigida está associada a este sistema de cisalhamentos transcorrentes que definem diferentes domínios estruturais. Definiu-se uma foliação principal (S2), desenvolvida durante a segunda fase de deformação, associado a qual ocorreu o pico do metamorfismo. Localmente, a foliação $\$ 2$ é milonítica, apresentando um arranjo do tipo S-C, desenvolvido em zonas de cisalhamentos sub-horizontais, que definem sistemas de cavalgamentos, com transporte para sudeste. Estas estruturas estão deformadas por uma terceira fase de deformação que dobra a foliação $\$ 2$, transpondo-a localmente, e gera zonas de cisalhamentos sub-verticais de caráter transcorrente, que adquire expressão regional.

Dados de geotermometria e geobarometria indicam condições metamórficas contrastantes, apontando para distintos ambientes tectônicos, sugerindo distintos regimes deformacionais e um grande transporte lâminas crustais quando da extrusão e justaposição dos terrenos tectôno-estratigráficos definidos. 
O baixo gradiente térmico impresso nas rochas do Complexo Riacho Gravatá, na Amêndoa Macacos-Piaus, é compativel com o metamorfismo em zonas de subducção, por outro lado na Amêndoa (antiformal) Piancó e nos Xistos Sertânia, as condiçöes metamórficas admitem paleogeotermas comprimidas e paleogradiente térmico abrupto, típicos de crosta adelgaçada, sob alto fluxo térmico, encontrado em bacias extensionais. Os registros comparáveis a ambientes de subducção, preservados na Amêndoa Macacos-Piaus devem estar ligadas a um processo de underthrust, dirigido para noroeste, de crosta continental relativamente fria, à profundidades de $30 \mathrm{~km}$. 


\section{ABSTRACT}

The Piancó-Alto Brigida Belts is located in the Rio Pajeú Tectonic Domain. It comprises various tectono-stratigraphic terranes, which were developed under contrasting metamorphic and deformational conditions, and put together during the Brasiliano Orogeny (750 to $580 \mathrm{Ma}$ ).

The following stratigraphic sequence has been defined: Serra Talhada Complex, comprising Paleoproterozoic orthogneisses and migmatites, reworked during the Brasiliano Orogeny; Riacho Gravatá Complex, comprising a metavolcano metasedimentary sequence, developed during a Mesoproterozoic crustal extensional regime, showing characteristics of both platform and continental slope sedimentation; Cachoeirinha Complex, comprising a Neoproterozoic metavolcano metasedimentary sequence with a magmatic arc affinity; Serra do Olho D'Água Sequence, comprising by a Late Neoproterozoic molasse; Sertânia Shists, comprising by a metavolcano metasedimentary sequence correleted to the Mesoproterozoic Setânia Complex. These sequences show the same main metamorphic foliation, originally subhorizontal, which was generated during the second deformational phase.

Six plutonic suites have been identified in the study area: five of them show Brasiliano age (Itaporanga-type, Catingueira-type, Triunfo-type, Taperoá-type, S-type and Conceição type granitoids) and the other comprised by orthogneisses of Cariris Velhos age.

The Piancó-Alto Brigida Belt structural frame is related to a system of transcurrent shear zones which define differen structural domains. These shear zones overprint older structures related to the generation of the sub-horizontal foliation (S2), during the second deformational phase. The peak of metamorphism occurred synchronously to the genesis of the $\mathrm{S} 2$ foliation. Localiy the S2 foliation is milonitic, with S-C type arrangement, developed in the subhorizontal shear zones, which define thrust systems with transport to the southeast. These were also deformed during a third phase which folded the $\$ 2$ foliation, transposed it locally, generating local sub-vertical shear zones. These later structures gain a regional importance and a transcurrent character delimiting the above mencioned terranes.

Geothermometry and geobarometry suggest contrasting metamorphic conditions, pointing to different tectonic environments, and suggesting different deformational regimes and large transportation of crustal segments during the escape tectonic and juxtaposition of the various tectono-stratigraphic terranes.

The low thermal gradient printed in the Riacho Gravatá Complex rocks (Amêndoa Macacos-Piaus) shows values which are compatible with metamorphism above subduction zones. On the other hand, in the Amêndoa Piancó and the Sertânia Schists the metamorphic 
conditions suggests the occurence of compressed paleogeotherms and abrupt thermal gradients. These thermal regimes are typical of thin crusts under high thermal heat flow which allow, on a regional scale, the ascension of heat to higher crustal levels, commonly found in extensional basins. The record discussed above, which is preserved in the Macacos-Piaus, is typical of subduction related environmental, and suggest na underthrust process of cold continental crust to a deepness of $30 \mathrm{Km}$ and towards the NW. 


\section{INTRODUÇÃO}

\section{I.1 LOCALIZAÇÃO, ACESSOS E ASPECTOS FISIOGRÁFICOS}

A área estudada localiza-se na Região Nordeste do Brasil, na divisa entre os estados de Pernambuco e Paraíba, entre os meridianos de $7^{\circ} 00^{\prime}-8^{\circ} 00^{\prime}$ de longitude sul e $37^{\circ} 30^{\prime}$ $38^{\circ} 30^{\prime}$ de latitude oeste. Estas coordenadas compreendem as folhas topográficas, da SUDENE/DRM, na escala de 1:100.000, Serra Talhada, SB-24-ZC-V, Itaporanga, SB-24-ZC-II, Piancó, SB-24-ZC-III, e Afogados da Ingazeira, SB-24-ZC-VI, as quais foram parcialmente mapeadas no presente trabalho. (Anexo 1)

O acesso a área pode ser feito a partir da Cidade de Recife, pela BR-232, atravessando - Estado de Pernambuco chegando-se às cidades de Serra Talhada e Afogados da Ingazeira, ou pela BR-230, através do Estado da Paraíba até a Cidade de Patos e dai pegando-se a BR361 em direção as cidades de Piancó e ltaporanga. (Fig. 1)

Geomorfológicamente, esta área está inserida no Planalto da Borborema, constituindo a porção central do Polígono das Secas, sendo cortada pela Bacia Hidrográfica do Rio Pajeú e pela Bacia Hidrográfica do Rio Piancó.

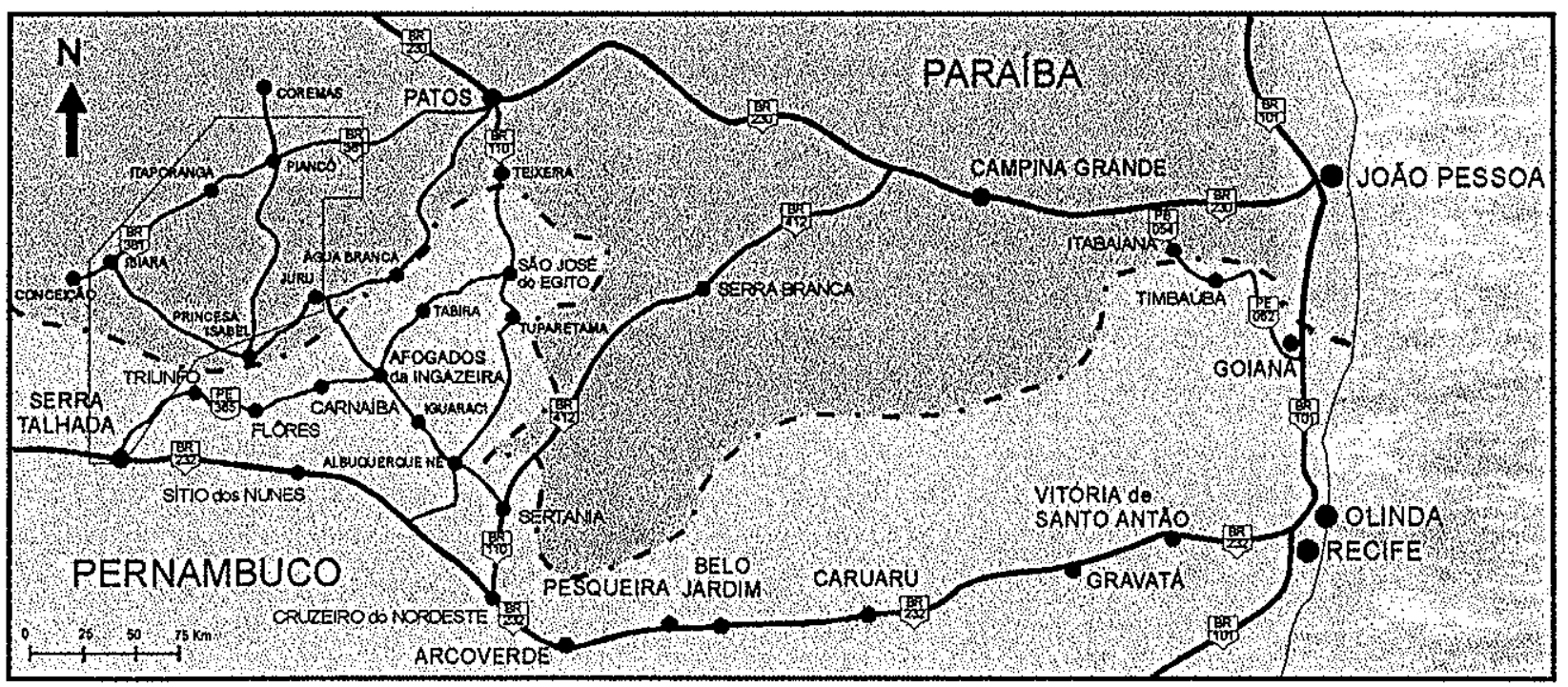

Fig. 1) Mapa de acessos à área do presente trabalho, com a localização da área estudada. 


\section{I.2 OBJETIVOS}

O presente trabalho tem como objetivo principal, fornecer subsídios para a elucidação da evolução geotectônica da Faixa de Dobramentos Piancó-Alto Brígida (Brito Neves, 1983), a qual, devido ao posicionamento geográfico e geotectônico, é de suma importância para o entendimento da evolução da Província Borborema.

$\mathrm{Na}$ tentativa de atingir este objetivo, utilizou-se o mapeamento geológico-estrutural de uma área pré-selecionada dentro da Faixa Piancó-Alto Brígida (Fig. 2). A este mapeamento foram associados: 1) estudos litoestratigráficos das sequências metavulcânicas $e$ metassedimentares mapeadas, na tentativa de se estabelecer o "tipo" de bacia sedimentar onde tais sequências foram depositadas; 2) análise estrutural e cinemática, buscando caracterizar a orientação, geometria e superposição das estruturas observadas, além do sentido de transporte tectônico a elas relacionados; 3) estudos microtectônicos, para tentar correlacionar os fenômenos de deformação e metamorfismo, e organizar temporalmente as transformaçōes observadas; e 4) estudos termobarométricos, visando quantificar as condições de temperatura e pressão do metamorfismo observado nas diversas unidades mapeadas, a partir das associações mineralógicas observadas em lâminas delgadas, e do uso de geotermômetros e geobarômetros compatíveis com as mesmas.

A compilação de datações geocronológicas e isotópicos existentes na literatura, associados aos dados acima citados, permitiu tentativamente a reconstituição paleogeográfica nos seus grandes traços e a caracterização dos eventos tectônicos geocronológicamente reconhecidos: Cariris Velhos e Brasiliano (Campos Neto et al, 1994a e 1994b; Brito Neves et al, 1995). 


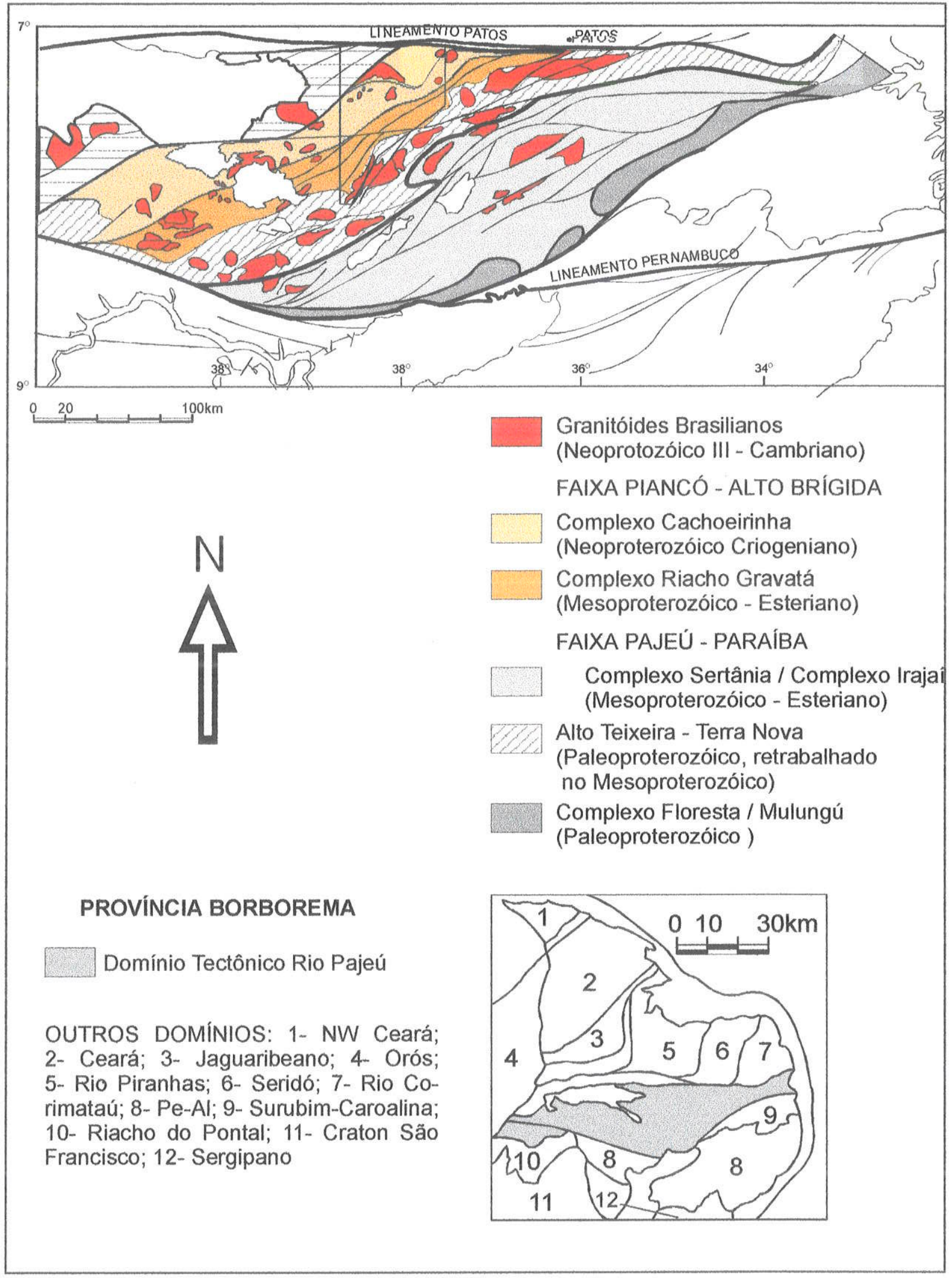

Fig. 2) Esboço geotectônico do Domínio Tectônico Rio Pajeú e adjacências, (Campos Neto et al, 1994a, modificado). 


\section{I.3 MÉTODOS}

Além de pesquisas bibliográficas, visando a interação com a problemática existente na geologia da Província Borborema, e também de assuntos inerentes as metodologias aplicadas, o desenvolvimento da presente tese contou com o trabalho de fotointerpretação de fotografias aéreas, na escala de 1:40.000, do Serviços Aerofotogramétricos da Cruzeiro do Sul (1965), disponiveis no DEGEO-UFPE e na CRPM - PE. Os dados de fotointerpretação foram compilados para os mapas topográficos na escala de 1:100.000, da SUDENE/DRM, folhas Serra Talhada, Itaporanga, Piancó e Afogados da Ingazeira.

A partir de perfis litoestruturais detalhados, realizados no campo, associados à fotointerpretação, confeccionou-se o mapa geológico final na escala de 1:250.000, de parte das quatro fothas topográficas citadas. (Anexo 1)

Mapas geológicos preexistentes, como os das folhas Serra Talhada, Itaporanga, Piancó e São José do Belmonte (Silva Fitho et al, 1985), o da Folha Afogados da Ingazeira (Veiga Junior et al, 1990), o mapa de Medeiros (1995), onde granitóides brasilianos da Faixa PiancóAlto Brígida estäo cartografados, o de Mariano (1989) onde se tem a cartografia do granito Itaporanga e adjacências, o mapa de Cunha (1996) com a cartografia dos granitos de Boa Ventura, Pedra Branca e Conceição, foram consultados e juntamente com comunicaçóes verbais de Ignês do $P$. Guimarães e Vladimir $C$. de Medeiros, auxiliaram, principalmente, no que tange a cartografia de alguns corpos ígneos existentes na área da presente tese.

O mapeamento geológico-estrutural, as análises cinemáticas e os estudos microtectônicos, seguiram as técnicas de uso comum, amplamente referidas na literatura.

O estudo das condiçőes de temperatura e pressão a que uma rocha esteve submetida envolve, além da petrografia e microtectônica, a análise química de minerais em para gênese. Estas análises foram realizadas no Laboratório de Microssonda e Microscopia Eletrônicas do Departamento de Mineralogia e Petrologia - IG/USP.

A quantificaçăo da temperatura e da pressão contou com o uso dos geotermômetros, granada-biotita (Ferry \& Spear, 1978; Lavrenteva \& Perchuck i 1981; Aranovich, 1983), granada-clorita (Perchuck (1991), granada-hornblenda (Graham \& Powell, 1984; Perchuck, 1991) e hornblenda-plagioclásio (Blundy \& Holland, 1990; Holland \& Blundy, 1994: Spear, 1981), e dos geobarômetros, granada-biotita-plagioclásio-muscovita (Ghent \& Stout, 1981), granada-plagioclásio-aluminossilicato-quartzo (Hodges \& Spear, 1982), granada-hornblendaplagioclásio-quartzo (Kohn \& Spear, 1989 e 1990) e do geotermobarômetro plagioclásioanfibólio (Plyusnina, 1982), cujas consistência serão discutidas no capítulo IV. 


\section{I.4 TRABALHOS ANTERIORES}

Dentre os trabalhos existentes na literatura, que remontam desde o final do século XIX, destacam-se aqueles referentes a geologia local e os cunho regional e/ou geotectônico, os quais julgamos serem importantes para a compreensão do exposto no presente trabalho.

Um dos mais antigos registros geológicos é o de Derby (1881), onde o autor descreve: "uma linha contínua de montanhas entre a qual e o rio" (São Francisco), "ficam numerosos serrotes destacados. Esta linha parece estabelecer-se para norte, em Pernambuco e Paraíba, e forma o sistema da Borborema" (posteriormente, designada Província Borborema).

Dombre (1893) cita, dentre outras litologias, a presença de gnaisses miloníticos e granulitos em Calumbi (leste de Serra Talhada) e um granito porfiróide na região de Flores.

Crandall (1910) que descreve ao norte da cidade de Serra Talhada um granito porfiróide.

Os trabalhos de Ebert $(1955,1957,1964,1969 a$ e 1969b) calcado em dados litoestratigráficos, estruturais e metamórficos, por vezes associados a datações radiométricas merecem destaque. Dentre estes o de 1964, onde o autor descreve a existência de dois ciclos orogênicos principais: um Arqueano (1,1 Ga, correspondente a Orogênese Laurenciana), onde são frequentes magmatitos básicos a intermediários, raros metassedimentos quartzíticos $\mathrm{e}$, extremamente raros os carbonatos; e o outro ciclo, Algonquiano (550 Ma, correspondente a Orogênese Assintica), com metassedimentos formando extensas camadas passíveis de subdivisão estratigráfica, ausência de magmatismo básico inicial, raras intercalações ultramáficas, frequentes zonas de xistos micáceos e paragnaisses, quartzitos comuns, e conglomerados nos horizontes inferiores.

Ebert (1964) descreve três compartimentos tectônicos, com base no estilo tectônicoestrutural gerado durante a orogênese de $550 \mathrm{Ma}$. O compartimento mais setentrional, abrangendo os estados do CE e RN, apresentando uma estrutura em dobras com planos axiais verticais e linhas estruturais de direção NE-SW a NNE-SSW. O compartimento meridional de mesma direção, porém com uma estrutura em escamas com vergência para NW e diminuição no grau metamórfico para NW, situando o ante-país situado a nordeste e a zona central da orogênese, a sudeste. $O$ terceiro compartimento, designado de a zona transversal (abrangendo os estados de PB e PE), com direções ENE-WSW a E-W, cuja estruturação interna é caracterizada por deformaçăo mais intensa, limitado a norte pelo Lineamento Paraiba (de movimento destral, posteriormente designado Lineamento Patos) e a sul pelo Lineamento Pernambuco. 
Ainda em 1964, Ebert conclui, com base na identidade entre a estruturação litológica e cronológica do Pré-Cambriano das Guianas e do Brasil, que estes devem estar relacionados a um único escudo, e observa que o Lineamento Pernambuco entra pelo Atlântico e segue para a África ("Linha de Camerum"), com correlação das direções estruturais em ambos os lados, respaldando a teoria de Wegner.

Barbosa (1970) define para a zona transversal de Ebert (1964) uma estratigrafia que, da base para o topo, apresenta: Grupo Uauá, arqueano (?), predominantemente, constituído por para-metamorfitos, localmente, migmatizado, representados por: biotita-gnaisses, biotitaxistos feldspáticos, metagrauvacas, muscovita-xistos, leptinitos, muscovita-gnaisses, muscovita-quartzitos, quartzitos puros, quartzo-itabiritos, anfibolitos (localmente com granadas), calcáreos sacaróides lenticulares (por vezes dolomítico), mármores e esteatitos, aos quais intercalam-se gnaisses porfiróides não metassomáticos); Grupo Salgueiro, constituído por biotita-xistos, xistos duas micas e quartzitos; e Grupo Cachoeirinha, designação provisória para xistos menos metamórficos que os do Grupo Salgueiro, dentro do qual constam mica-xistos finos, filitos, clorita-xistos, anfibolitos, itabiritos e quartzitos prateados e, localmente, metaconglomerados com seixos de quartzito fino maciço (São José do Belmonte). Barbosa (1970) descreve corpos granitóides intrusivos nos três grupos e observa que os contatos entre as rochas dos grupo Salgueiro e Cachoeirinha com as do Grupo Uauá são transicionais.

Sadowski (1972) descreve o maciço intrusivo da Serra da Baixa Verde, localizado próximo a Cidade de Triunfo, como um quartzo-augita sienito tardi-tectônico de idade EoCambriana, resultante de diferenciação magmática.

Segundo Brito Neves (1975) a Regiấo Nordeste do Brasil é o "produto da tectogênese ao final do Pré-Cambriano de uma região geossinclinal em mosaico, de preenchimento essencialmente terrigeno, entre as porções cratônicas do São Francisco (Congo), ao sul, e São Luís/Gurupi (Nordeste da África), ao norte". Dentro deste esquema cinco elementos geotectônicos são definidos: núcleos cratônicos (São Francisco, São Luís), lineamentos e falhas profundas (Pernambuco, Paraíba, Sobral Pedro II), maciços medianos (PernambucoAlagoas, Rio Piranhas, Tróia, Santa Quitéria, Granja), zonas geoanticlinas (Propriá, Teixeira, Nova Floresta) e as faixas ou sistemas de dobramentos (Sergipana, Riacho do Pontal, PajeúParaíba, Piancó-Alto Brígida, Seridó, Jaguaribeana, Médio Coreaú).

Brito Neves (1975), baseado em dados geocronológicos (K-Ar e Rb-Sr), sugere os seguintes eventos tectônicos: o Ciclo Guriense/Jequié $(2.800 \pm 200 \mathrm{Ma})$ responsável pela formação de núcleos antigos na área dos atuais craton do São Francisco e Maciço PE-AL; o Ciclo Transamazônico $(2.000 \pm 200 \mathrm{Ma})$, associado a principal etapa de cratonização do embasamento da regiáo dobrada, ao rejuvenescimento isotópiç, ao retrabalhamento de áreas 
consolidadas no ciclo anterior e ao magmatismo granítico, básico e ultrabásico; o ciclo de $1.100 \pm 150 \mathrm{Ma}$ (comparado ao ciclos Uruaçuano e Guriense), responsável pela etapa termotectônica regional, salientada pelo rejuvenescimento isotópico nos maciços medianos (especialmente nas bordas) e na área do craton de São Luis, e pela instalação da região geossinclinal, ocasionando a intensa diferenciação tectônica da protoplataforma, acompanhada por modificações no gradiente térmico, e pelas primeiras manifestações magmáticas; e, por fim o Ciclo Brasiliano. Este último ciclo é subdividido por Brito Neves (1975) em: etapa principal, de $650 \pm 30 \mathrm{Ma}$, quando ocorreu a finalização da deformação, metamorfismo e granitização sin-tectônica, e o rejuvenescimento tectônico e termal de grande parte das rochas do embasamento e dos maciços medianos; etapa de $540 \pm 30 \mathrm{Ma}$, constituida por um evento tardio, com a instalação de inúmeros corpos graníticos e sieníticos circunscritos, remobilização de rochas preexistentes e movimentação ao longo dos lineamentos; e etapa de 510 - $460 \mathrm{Ma}$, onde ocorreu o posicionamento de intrusivas fissurais e veios hidrotermais, soerguimento e resfriamento gradativo da região dobrada, sedimentação molássica nas depressões tectônicas residuais com magmatismo associado, ativação dos lineamentos e incorporação da região dobrada à plataforma.

Na Faixa de Dobramentos Piancó-Alto Brígida, Brito Neves (1975) descreve no embasamento, o predomínio de migmatitos, gnaisses graníticos, gnaisses listrados e augengnaisses associados a intrusões graníticas, que podem ser confundidos com a sequência superior migmatizada. Sobre o embasamento, Brito Neves (1975) descreve a sequência superior, onde reconhece uma sequência terrigena basal e uma sequência mais superior, que mostram contatos gradacionais entre si. A sequência terrígena basal, designada de Grupo Salgueiro, mostra metamorfismo do fácies xisto verde ao anfibolito, localmente migmatizada. Constitui uma sequência psamítica média a fina (gnaisses quartzo feldspáticos) com intercalações de pelitos (gnaisses micáceos e xistos), sedimentos químico-clásticos (anfibolitos e escarnitos) e químicos (calcáreos e dolomitos), com pequenos corpos irregulares de ortoanfibolitos e metadioritos observados localmente. A sequência terrigena superior, designada de Grupo Cachoeirinha, apresenta na base lentes descontínuas de quartzitos, seguidos por sedimentos pelíticos a psamíticos finos, metamorfoseados no fácies xisto verde, localmente, chegando ao fácies anfibolito. São filitos e metasiltitos com horizontes quartzíticos subordinados, com ocorrências restritas de quartzo-itabiritos, calcários e conglomerados. Sobre a sequência superior (grupos Salgueiro e Cachoeirinha), em discordância, ocorre localmente uma sequência molássica, com siltitos, grauvacas e brechas pelíticas.

Na Faixa de Dobramentos Pajeú-Paraíba, Brito Neves (1975) reconhece um embasamento onde predominam rochas gnáissicas de compoșiçäo granítica a granodiorítica e 
migmatitos com paleossoma biotítico e anfibolítico, expostos ao longo dos grandes geoanticlinais e nas zonas marginais da faixa. Sobre o embasamento são descritas duas sequências: a sequência inferior sedimentar terrigena marinha imatura (psamítica a psamopelítica com níveis carbonáticos e niveis quartzíticos passando no topo a xistos) metamorfisada no fácies anfibolito e localmente migmatizada; e a sequência superior, constituída por sedimentos clásticos de ambiente marinho mais profundo (representada por um fácies argiloso, níveis carbonáticos mais expressivos, e níveis quartzíticos na base), metamorfisada no fácies anfibolito, chegando a anatexia e, localmente, no fácies xisto verde.

Separando as duas faixas acima descritas, Brito Neves (1975) define o Alto, Zona, Geoanticlinal ou Maciço do Teixeira, com uma extensão de cerca de $480 \mathrm{~km}$ e com largura entre 15 e $20 \mathrm{~km}$ que separa as Faixa de Dobramentos Piancó-Alto Brígida e Faixa de Dobramentos Pajeú-Paraiba. O Alto do Teixeira se estende, na direção NE, desde Barro da Silva (PE), até Teixeira (PB) e apartir daí, com direção $E-W$, projeta-se até a zona costeira. $\mathrm{Na}$ região oriental, o Alto Teixeira é mais largo $(60 \mathrm{~km})$ e se bifurca, apresentando características de um autêntico maciço mediano, com grabens preservando frações de cobertura tipo geossinclinal, ao mesmo tempo que funciona como um bloco rígido para o qual se divergem as vergências das faixas dobradas. As faixas separadas pelo Alto do Teixeira (faixas Piancó-Alto Brígida e Pajeú-Paraiba) tiveram evolução distintas em termos de sedimentação, tectogênese e grau de metamorfismo. A presença de quartzitos nos flancos do Alto do Teixeira é interpretada como reflexo da posição paleogeográfica elevada, nos estágios inicias do seu assoreamento. Nos estágios principais de dobramento, o Alto de Teixeira teria se comportado em grande parte como antepaís. Brito Neves (1975), seguindo a classificação de Almeida (1967), reconhece corpos graníticos sin-cinemáticos (tipo ltaporanga, tipo Conceição) e tarditectônicos (tipo "baixa Verde e tipo Itapetim) e pós-tectônicos (diques sieníticos).

Brito Neves (1975) descreve núcleos mais antigos, principalmente, na porção oriental do Alto do Teixeira. São migmatitos, gnaisses graníticos e granitóides de idades transamazônicas $\left(1.85 \pm 70 \mathrm{Ga}\right.$, e razão inicial ${ }^{87} \mathrm{Sr} /{ }^{86} \mathrm{Sr}$ de $\left.0.706 \pm 0.002\right)$ ou mais antiga (2.5 $\pm 93 \mathrm{Ma}$, e mesma razão inicial) com rejuvenescimento parcial ou total durante o Brasiliano. Rochas básicas das bordas do Alto do Teixeira apresentaram idades convencionais da ordem de $1.15 \mathrm{Ga}$ (e razão inicial de $0.703 \pm 0.001$ ). Esta idade, que segundo Brito Neves (1975), poderia representar a idade aproximada da formação destas rochas em função de razão inicial assumida e do bom alinhamento isocrônico, foi por ele interpretada como idade de rejuvenescimento, causada por potassificação e deformação, em parte em função de seu contexto geológico (núcleos reliquiares). Dados KIAr destas amostras são interpretados da mesma forma: rejuvenescimento de rochas, provavelmente, transamazônicas (ou mais 
antigas) parcial (1253 $\pm 64 \mathrm{Ma}$ ) ou total ( $764 \pm 20 \mathrm{Ma}$ ) ao longo dos eventos inerentes aos diferentes processos metamórficos do Brasiliano, sem entretanto excluir totalmente a hipótese da formação destas rochas a 1150 Ma conforme a isócrona da referência.

Para a zona geoanticlinal de Camalau-Aroeira (aftoramentos próximo a Coxixola, $P B$ ), Brito Neves (1975) obteve idades convencionais entre 710 e $900 \mathrm{Ma}$ (razão inicial de $0.708 \pm$ 0.001) e num diagrama isocrônico duvidoso, obteve uma isócrona de referência de $950 \mathrm{Ma}$ (razão inicial de 0.704). No Maciço PE-AL a idade de isocrônica de referência dá $650 \pm 30$ Ma e é interpretada como reflexo do rejuvenescimento brasiliano.

Santos (1977), mapeando a Folha Arco Verde, identificou um conjunto de rochas constituída por migmatitos, gnaisses graníticos e granitóides do Pré-Cambriano Médio a Inferior, designados de Sequência Mulungu, e um outro conjunto de rochas, do Pré-Cambriano Superior, que foram subdivididas em: xistos do tipo Caroalina e Complexo Alto Moxotó. Este último é constituído por gnaisses migmatíticos subdivididos, com base no protólito, nas sequências Dom Feliciano (protólito máfico-ultramáfico), Sertânia (pelítico) e São Caetâno (protólito psamo-pelítico).

Gomes et al (1981) apresentam para a "Região de Dobramentos Nordeste" uma subdivisão em províncias geológicas de similar história evolutiva (as províncias: São Francisco, da Borborema, Sergipana, Riacho do Pontal, do Paraíba e Costeira). Neste trabalho, além de uma boa revisão bibliográfica cerca da estratigrafia do Pré-Cambriano do Nordeste, é definido - Complexo Monteiro, como uma sequência, essencialmente, constituída por gnaisses e migmatitos, de idade pré-cambriana inferior a média, correlacionável aos grupos Uauá e Caicó. Os referidos autores utilizam a subdivisão do Grupo Cachoeirinha proposta por França et al (1980), constituído por: sequência basal (micaxistos as vezes manganesíferos, filitos, filitos grafitosos, quartzitos, rochas carbonáticas, metarritmitos e metavulcânicas intermediárias), sequência inferior (metaconglomerado, sotoposto por filitos, filitos grafitosos, xistos, lentes de quartzitos, metassiltitos e metavulcânicas básicas e ácidas, depositadas em ambiente redutor), sequência média (mica-xistos e filitos, com metassiltitos, lentes de quartzitos, metacalcáreos, itabiritos e de rochas ortoderivadas associadas) e sequência superior (predomínio de filitos e mica-xistos, com quartzitos, ardósias, metacarbonatos e metavulcânicas associadas, que mostram, localmente, contatos gradacionais com a sequência média). Dados $\mathrm{Rb} / \mathrm{Sr}$ e K/Ar das rochas do Grupo Cachoeirinha fornecem idade de metamorfismo no Ciclo Brasiliano (580 Ma) e uma fase tardi-tectônica a $470 \mathrm{Ma}$ (no Cambriano) obtida em rochas próximas a falhamentos e em rochas granitóides intrusivas nesta sequência. O Grupo Salgueiro é interpretado (Gomes et al, 1981) como correlato ao Grupo Cacheirinha, sendo às vezes de difícil distinção. Estas conceituações são basicamente seguidas por Gava et al (1983). 
Jardim de Sá \& Hackspacher (1981) introduziram para a Província Borborema o conceito de evolução policíclica para algumas faixas de dobramento.

Brito Neves (1983) define na Província Borborema dois tipos fundamentais de terrenos Pré-Cambrianos sem quaisquer implicações geotectônicas: os terrenos gnáissico-migmatíticogranítico e os terrenos metassedimentares e metavulcanossedimentares ou cinturões metamórficos, e divide estes terrenos em cinco domínios geológicos distintos: (a) domínio externo (em número de dois) por ser proximal aos núcleos cratônicos e constituído por metassedimentos de baixo grau, ricos em níveis carbonáticos; (b) domínio central (subdividido em três subdomínios), onde predominam rochas epi e mesozonais, cortadas por granitóides; e (c) o domínio de posição intermediária entre os dois anteriores (em número de dois), onde predomina a exposição de terrenos gnáissico-migmatíticos e migmatítico-graníticos, tidos como rochas da infra-estrutura, que afloram como feições reliquiares entre metamorfitos, e designados de "sistemas vestigiais". Os domínios central e externo são também designados "sistemas convencionais" ou faixas orogênicas. Os terrenos metassedimentares ou cinturões metamórficos são também designados de sistemas de dobramentos, os quais foram denominados sistemas: Pajeú-Paraíba, Riacho do Pontal, Piancó-Alto Brigida, Seridó, Jaguaribeano e Rio Jurú / Independência.

Sial et al (1983) dividem as rochas da Faixa de Dobramentos Piancó-Alto Brígida em duas unidades: a) Complexo Riacho Pequeno e b) Complexo Cachoeirinha-Salgueiro, esta última agrupando os grupos Cachoeirinha e Salgueiro.

Santos et al. (in Schobbenhaus, 1984) subdividem o Pré-Cambriano do Nordeste em domínios estruturais mais genéricos, sem conotação geotectônica, a saber os domínios: Médio Coreaú, Cearense, Transnordestino (com os subdomínios Seridó, Piancó-Alto Brígida e Riacho do Pontal), Extremo Nordeste e Sergipano, que em muito se assemelham aos domínios propostos por Brito Neves (1983).

Silva Filho et al (1985) subdividem, com base no padrão deformacional, conteúdo metalogenético e grau metamórfico, as rochas da Faixa de Dobramentos Piancó-Alto Brígida, em quatro unidades litológicas: o "Pré-Cambriano indiferenciado"; com milonitos e gnaisses miloníticos derivados de granitóides ou de migmatitos; o "grupo inferior", correlacionado ao Grupo Uauá (Proterozóico Inferior); o "Grupo Salgueiro" (Proterozóico Médio), com cinco subunidades, formado por uma sequência metavulcanossedimentar com vulcanismo bimodal; - Grupo Seridó (correlacionável ao Grupo Salgueiro do qual difere pelo grau metamórfico mais elevado), e o "Grupo Cachoeirinha", com três subunidades, constituído, predominantemente, por metassedimentos, que jazem discordantemente sobre o Grupo Salgueiro. No topo, disposto em discordância sobre todas estas unidades, é descrito como "grupo superior", um 
conjunto de rochas imaturas tipo molássa. O metamorfismo diminui do grupo inferior, de grau médio a alto, localmente, de pressão alta (São José do Belmonte), até a sequência molássica, com grau fraco a incipiente. Nos grupos inferior e Salgueiro foram caracterizadas 3 fases de metamorfismo e 4 fases de deformação, não observadas no Grupo Cachoeirinha e na sequência molássica. Cortando tais sequências são descritas diversas rochas plutônicas, para as quais é proposto o seguinte esquema evolutivo: (a) intrusões básicas (plutons básicos, intermediários e ultrabásicos) as quais teriam sido a fonte de calor necessária para provocar fusão, resultando em um líquido híbrido, dentro do qual cristalizavam pequenas frações imissíveis de magma básico; (b) evolução do processo palingenético com diferenciação do magma granítico em várias frações dando origem a suíte alcalina que ocorre nesta área. Segundo os autores referidos, este modelo geodinâmico, poderia ter evoluido tanto a partir de junções destrutivas de placas como nas construtivas.

Marques e Souza (1985) utilizando 18 mostras de rochas metabásicas, concluem que 13 destas representavam basaltos toleiiticos e, sugerem um ambiente tectônico do tipo rifte para a sequência metavulcanossedimentar do Domínio Estrutural Central. A análise de 35 amostras de rochas plutônicas da porção central do mesmo domínio, definem um ambiente tectônico distensivo, com geração de magmas a grandes profundidades. Os referidos autores sugerem ainda, que a sequência metavulcânica pode ser de idade arqueana devido seu caracter komateítico.

Ferreira (1986) estudando as rochas peralcalinas de provável idade brasiliana que intrudem nos metassedimentos dos Grupos Cachoeirinha-Salgueiro, observa a existência de dois grupos: ultrapotássicas saturadas em sílica (alcali-feldspato-sienito) e ultrapotássicas supersaturadas em sílica (quartzo-alcali-feldspato-sienito a alcali-feldspato-granito com fluorita e cassiterita). O primeiro grupo forma batólitos e diques alinhados, adjacentes aos bordos SE e SW do "cinturão Cachoeirinha-Salgueiro", descrevendo um "cordão sienitóide" e enxame de diques intrusivos nos metassedimentos do Grupo Cachoeirinha. A maioria dos corpos do cordão sienitóide contém inclusões alcali-piroxeníticas e no bordo sudoeste, sienitos ocorrem intercalados com gabros, metamorfisados no fácies anfibolito. Corpos do segundo grupo ocorrem como batólitos, stocks e diques, que cortam metassedimentos do cinturăo Cachoeirinha-Salgueiro. A partir de dados de isótopos ${ }^{18} \mathrm{O} /{ }^{16} \mathrm{O}$, Ferreira (1986), sugere que o batólito Triunfo (grupo saturado) foi gerado pela diferenciação de magma basáltico derivado do manto, que se separou em dois magmas de composição contrastantes (sienítico e piroxenítico) por um processo de imiscibilidade de líquidos, e que as rochas do grupo supersaturado sofreram alteração posterior por água meteórica interagindo com feldspato. $O$ intenso fracionamento inicial, de piroxênio, a partir de um magma máfico alcalino, enriquecimento em 
elementos incompatíveis, gerado no manto superior, foi responsável pela geração dos sienitos do cordão sienitóide, estando o posicionamento destes corpos relacionados ao desenvolvimento inicial de um rifte no Proterozóico. Os plutons saturados receberam maior contribuição crustal em sua evolução e constituem um evento de atividade peralcalina mais recente, que o evento que formou as rochas peralcalinas do cordão sienitóide.

Jardim de Sá (1984, 1988 e 1994) e Jardim de Sá et al (1990 e 1992), com base no conceito de evolução policíclica $X$ evolução monocíclica para as faixas de dobramentos, sugerem que as faixas de dobramentos adjacentes aos cratons e o magmatismo abundante na Província Borborema teriam sido gerados no Neoproterozóico, enquanto as faixas de dobramentos mais interiores teriam sua evolução iniciada no Ciclo Transamazônico com retrabalhamento no Ciclo Brasiliano, e propõem uma subdivisão para a província, retomando o termo "Zona Transversal" de Ebert (1964).

Beurlen (1988) estudando rochas metamáficas das regiões de Floresta e Bodocó (limite sul do Domínio Estrutural Central), determinou, através de química mineral, um evento metamórfico em regime de alta pressão (13 2 kb e $580 \pm 60 \mathrm{C}$ ), no fácies eclogito.

Silva Filho (1989) sugerem uma tectônica de baixo ânguio associada a um processo de colisão e encurtamento crustal durante a intrusão da suíte ultrapotássica da área de Terra Nova, PE.

Guimarães et al (1989), com base no estudo petrogenético do complexo intrusivo Bom Jardim, admite natureza shoshonítica deste complexo e seu posicionamento associado a falhas de baixo ângulo, são evidências de magmatismo relacionado a colisão de blocos continentais.

Vários autores estudaram diversos corpos granitóides do Faixa Piancó-Alto Brígida e Sial (1986 e 1987) e Sial et al (1989 e 1990) apresentam uma sintese sobre os vários corpos granitóides do Sistema Piancó-Alto Brígida, propondo a seguinte classificação: granodioritos a tonalitos calcioalcalinos, "tipo Conceição", posicionados, principalmente dentro do Grupo Cachoeirinha (Emas, Ouricuri, Conceição, Diamante e Ipueiras); granitos porfiríticos Kcalcioalcalinos, "tipo Itaporanga" (Itaporanga, Bodocó, Serra da Lagoinha, Brejinho, Prata e Sumé); sienitóides peralcalinos "tipo Catingueira / Triunfo" (Catingueira, Triunfo, Campo Grande, Urtiga, Bom Nome, Casé, Serra do Man, Serra da Penha e Passagem da Borborema); tonalitos e granodioritos leucocráticos com afinidades trondhjemíticas "tipo Serrita" (Serrita, Salgueiro e Teixeira); granitóides com afinidades shoshoníticas (parte do batólito de Terra Nova, porção central e leste do Teixeira, Serra do Arapuá, Serra Grande, Flores e Solidão).

Lima (1989) apresenta um quadro evolutivo tectono-metamórfico para as rochas proterozóicas de parte do segmento mediano do Domínio Estrutural Central, as quais 
constituem os xistos do Grupo Cachoeirinha. Química de rocha total nestas litologias indicam um protólito pelítico a semi-pelítico, provavelmente, depositado em um ambiente de margem continental ativa. As condições $P / T$ para estas rochas variam do fácies xisto verde ao anfibolito, com pressões e temperaturas estimadas entre $2-4 \mathrm{kbars}$ e $400^{\circ}-700^{\circ} \mathrm{C}$, apontando para um gradiente metamórfico de $30^{\circ}-40^{\circ} \mathrm{C} / \mathrm{km}$. Análise destes parâmetros, segundo Lima (1989), apontam para uma evoluçăo tectônica durante o Proterozóico, em ambiente de margem continental ativa, com consumo de crosta oceânica e posterior colisão continental. A associação mineral e feições estruturais das rochas do Grupo Cachoeirinha são explicadas através de uma evolução $P / T$, onde o pacote rochoso foi submetido a pressões moderadas, gerando um fábrica penetrativa proeminente $(S p)$ e cristalização e rotação de porfiroblástos de granada e estaurolita. Este evento teria ocorrido entre 1150 e $928 \mathrm{Ma}$. Uma vez atingida a pressão máxima, crescimento estático ocorre e temperatura máxima favorece as reações de desidratação, que teriam ocorrido entre 833 - $550 \mathrm{Ma}$, corroborado pela intensa atividade magmática no final do Proterozóico. Com a razão de erosão maior que o soterramento, todo pacote rochoso ascende e fábricas mais frágeis são formadas neste percurso.

Mariano (1989) estudando o Batólito Itaporanga de composição calcio-alcalina de alto potássio, intrusivo na região de contato entre os grupos Salgueiro e Cachoeirinha, interpreta seu posicionamento como um diápiro, segundo uma abertura pull-apart ao longo de uma falha direcional curva. Química de rocha total sugere que processos de mistura de magmas (magma quartzo monzonítico-granítico e magma K-diorítico) atuaram durante a evolução do batólito Itaporanga, apesar de processos de fracionamento e assimilaçăo magmáticas também terem ocorrido. Foliação subcircular sugere posicionamento diapírico final e que o nivel atual de exposição é a zona de raiz do diápiro, onde intensa interação entre magmas pode ocorrer. Idade isocrônica Rb-Sr de $620 \pm 20 \mathrm{Ma}$ (razão inicial de 0.7058 ), para o fácies porfirítico é apresentada por Mariano (1989), que a considera como a idade máxima de posicionamento. Idade Ar-Ar em hornblenda e biotita fornecem idade entre 580 e $540 \mathrm{Ma}$ (respectivamente). A idade Ar-Ar em hornblenda é interpretada como idade mínima de posicionamento ou de resfriamento e a idade Ar-Ar em biotita é a idade de resfriamento. Logo, o Batólito ltaporanga mostra uma taxa de resfriamento de $5^{\circ} \mathrm{C} / \mathrm{Ma}$ (taxa baixa) ou o registro de regime termal abaixo de $500^{\circ} \mathrm{C}$ e acima de $300^{\circ} \mathrm{C}$, que poderia estar associado zonas de cisalhamentos (Falha dos Cochos). Relações de campo levaram Mariano (1989) a sugerir que granitóides dos tipos Conceição e Itaporanga sejam cogenéticos, sendo o tipo Conceição mais novo. Dados de química mineral sugerem que o Batólito Itaporanga começou a se cristalizar a uma profundidade de $18-15 \mathrm{~km}$ (pressão de $5 \pm 1 \mathrm{kbar}$ ) e temperatura de $558^{\circ} \mathrm{C}$ (gradiente termal estimado de $30^{\circ} \mathrm{C}$ ), tendo seu posicionamento ocorrido durante o evento tectono-termal 
relacionado a Zona de Cisalhamento de Cochos que promoveu a mistura mecânica dos magmas.

Veiga Júnior et al (1990) descrevem na Folha Afogados da Ingazeira um complexo gnáissico-migmatítico, constituído por ortognaisses e gnaisses bandados, geralmente, migmatizados de composição granítica a granodiorítica, com leptinitos e ortoanfibolitos, tidos como as rochas mais antigas da regiẫo, além de outros três complexos, de provável idade proterozóica inferior, que congregam a Faixa de Dobramentos Pajeú-Paraíba. O Complexo São Caetano constituído por uma sequência terrígena psamo-pelítica, com gnaisses, xistos, leptinitos e quartzitos. O Complexo Irajaí que constitui um complexo metavulcânicometassedimentar com paragnaisses feldspáticos com intercalaçōes de calcários e anfibolitos e rochas metavulcânicas de natureza toleítica oceânica, associadas a arco de ilhas, compreendendo ortoanfibolitos e metatufos básicos, além de metacherts e de rochas calciossilicáticas. O Complexo Sertânia formado por uma sequência psamo-pelítica, constituida por gnaisses com intercalações de metacalcários e de rochas calciossilicáticas. Além desses complexos são descritos os grupos Cachoeirinha e Salgueiro na Faixa de Dobramentos Piancó-Alto Brígida, e rochas plutônicas, estas agrupadas em três suítes graníticas de acordo com seu posicionamento: aquelas relacionadas à deformação tangencial (Proterozóico Médio), as associadas a deformação transcorrente (Proterozóico Superior) e o plutonismo sin a póstranscorrência.

Brito Neves et al (1990) fornecem idades U-Pb em zircões de rochas metavulcânicas ácidas, da região de Macacos-Piaus $(\mathrm{Pb})$ e Manaira-Poço do Cachorro $(\mathrm{Pb})$, na Faixa de Dobramentos Piancó-Alto Brígida, de $1.1 \mathrm{Ga}$, interpretando esta como idade de erupção das rochas vulcânicas, enquanto as idades $\mathrm{Rb} / \mathrm{Sr}$ nas mesmas rochas, de $950 \mathrm{Ma}$, são interpretadas como idade do metamorfismo regional.

Bittar et al (1992), em um trabalho de reconhecimento, questionam a existência dos grupos Salgueiro e Cachoeirinha conforme descritos na literatura

Vauchez et al (1992) interpretam a estruturação da Província da Borborema como resultado da orogenia Brasiliana, a qual gerou uma complexa rede de zonas de cisalhamentos transcorrentes de escala continental, resultando em um sistema mecanicamente coerente ao longo de um único evento tectônico final, o Sistema de Zonas de Cisalhamento Borborema (SZCB), resultado de uma colisão obliqua na margem noroeste. O sistema teria se desenvolvido numa crosta quente e altamente plástica. Sugerem, a partir de estudos de petrofábricas que a atividade principal do SZCB é contemporânea ao metamorfismo de baixa pressão-alta temperatura e fusão crustal, e que tanto as zonas de cisalhamentos de direção NE-SW como as de direção E-W possuem movimento dextral. Ramos de direção $N$ a $N E$ 
mostram evidências de transpressão, enquanto zonas de cisalhamentos de direção $E-W$ são preenchidas por magmas sintectônicos, sugerindo transtensão.

Figueiredo et al (1992) interpretam os sistemas de cisalhamentos dextrais Patos-Seridó e Campina Grande como controladores dos processos orogênicos (deformação, metamorfismo e magmatismo, durante o ciclo Brasiliano, a 700 - $450 \mathrm{Ma}$ ), que afetaram distintos níveis estruturais do embasamento gnaissico-migmatítico arqueano e transamazônico e da cobertura sedimentar proterozóica. Baseado em dados geotermobarométricos e datações, estes autores descrevem dois eventos tectono-metamórficos descontínuos no tempo e espaço. Um de idade mínima $544 \pm 3$ Ma caracterizado pelo funcionamento sincrônico dos sistemas cisalhante litosféricos Patos-Seridó e Campina Grande, que durante esta fase estavam dispostos en relais e não apresentam continuidade estrutural. A deformação dos diferentes fácies datados é sin-metamórfica e de alta temperatura (fácies anfibolito, com temperaturas entre $550^{\circ}$ e $650^{\circ} \mathrm{C}$ ). No segundo evento termo-tectônico, de idade mínima de $505 \mathrm{Ma}$, os sistemas cisalhantes Patos-Seridó e Campina Grande são reativados simultaneamente e a deformação dúctil intensa, ao longo de bandas métricas de cisalhamento, é associada a um metamorfismo dinâmico no fácies xisto verde/anfibolito, com temperaturas entre $400^{\circ}-500^{\circ} \mathrm{C}$.

Accioly (1993), estudando as rochas metavulcânicas e metapelíticas a norte da Cidade de Serra Talhada, observou que estas foram metamorfoseadas em condições $P / T$ do fácies xisto verde baixo (zona da clorita) até o fácies anfibolito (zona da granada), com temperatura máxima da ordem de $550^{\circ} \mathrm{C}$, atingida durante a segunda fase de deformação (D2), e metamorfismo hidrotermal associado a cisalhamentos da terceira fase de deformação (D3). As rochas metavulcânicas foram subdivididas, com base na composição químico-mineralógica e posicionamento em relação a deformação principal (D2), nos grupos: (I) metariolitos e metariodacitos pré-D2; (II) microsienitos pós-D2; (III) metabasaltos, metandesitos e metatufos (actinolita xistos, clorita-epidoto-actinolita xistos) pré-D2; e (IV) metagabros. Para as rochas metavulcânicas básicas duas tendências geoquímicas são observadas: uma alcalina e a outra sub-alcalina toleiítica, apresentando enriquecimento em $\mathrm{K}, \mathrm{Rb}, \mathrm{Ba}$, e ETR leves, similares aos de toleiítos continentais recentes de ambientes intra-placa, com os padrões de ETR sugerindo enriquecimento crustal, o que é corroborado pela análises das rochas metavulcânicas ácidas e dos metassedimentos. Um modelo envolvendo deposição da sequência em ambiente distensivo do tipo rifte continental, com possivel formação de assoalho oceânico, fechamento da bacia durante as fases compressivas D1 e D2 e intrusão dos metabasitos sub-alcalinos dos grupo IV. Segue-se a fase transtencional com posicionamento de rochas sub-vulcânicas peralcalinas do grupo II. 
Silva Filho (1993) propõe uma subdivisão estatigráfica para as rochas da Faixa de Dobramentos Piancó-Alto Brígida, iniciando com os Grupo Uauá, Grupo Bom Nome e Complexo Sertânia, de idade mesoproterozóica, constituido por supracrustais e ortoderivadas de médio a alto grau metamórfico, sobre as quais, em discordância, depositou-se as rochas do Grupo Salgueiro, no final do Proterozóico Médio, constituído por filitos, grauvacas e metavulcânicas ácidas, intermediárias e básicas, interpretadas como depósitos relacionados a bacia extensional associada a arco vulcânico ou rifte. No topo, ocorre o Grupo Cachoeirinha, correspondendo a depósitos plataformais do Proterozóico Superior, em discordância sobre o Grupo Salgueiro.

Campos Neto et al (1994a e 1994b) propõem a designação de Domínio Tectônico Rio Pajeú (DTRP) para uma região situada entre os lineamentos Patos e Floresta, constituída pela Faixa de Dobramentos Piancó-Alto Brígida (FDPAB), Faixa de Dobramentos Pajeú-Paraíba (FDPP) e pelo Alto do Teixeira, que separa as faixas de dobramento. Na FDPAB descrevem informalmente: o Complexo Metavulcanossedimentar Riacho Gravatá (metavulcânicas ácidas, metagrauvacas e metarritimitos), Complexo Metavulcanossedimentar Poço dos Cachorros (predomínio de metabásicas), Complexo Meta-Turbidítico Serra do Olho D'Água (metaconglomerados polimíticos, metarritimitos, metapelitos e metagrauvacas depositados sob regime de correntes de turbidez) e Nappe Piancó (metagrauvacas e metapelitos). Na FDPP descrevem o Complexo Irajaj-Sertânia (metaplutônicas e metavulcânicas calcio-alcalinas e metagrauvacas vulcanoclásticas) e complexos metamórficos de alto grau (descritos por Beurlen, 1988; Beurien et al, 1990, 1991 e 1992; Santos et al, 1993).

Campos Neto et al (1994a e 1994b) propõem para o DTRP a seguinte evolução: (1) regime de adelgaçamento crustal de uma massa paleoproterozóica (Alto Teixeira); (2) estágio rifte $(1.1 \mathrm{Ga})$ representado pelo Complexo Metavulcanossedimentar Riacho Gravatá, com sedimentação e vulcanismo bimodal típicos; (3) Orogênese Cariris Velhos (1.0 Ga), com a inversão da tectônica distensiva para compressiva, com convergência de placas, deposição do Complexo Meta-Turbiditico Serra do Otho D'Água sobre o Complexo Metavulcanossedimentar Poço dos Cachorros, na FDPAB, e estabelecimento, na FDPP, de um arco magmático plutonovulcânico calcio-alcalino (onde o vulcanismo grada para sequências vulcanoclásticas do Complexo Irajaí-Sertânia) e pelos complexos metamórficos de alto grau relacionados à colisão; (4) Orogênese Transnordestina, sem registros de sedimentação no DTRP, representada por expressivo magmatismo plutônico a $620 \mathrm{Ma}$, com zoneamento químico que sugere uma origem relacionada a subducção, possivelmente para SE, com o arco magmático localizado na FDPAB. Granitos do tipo-S e tipo-I Caledonianos e uma granitogênese peralcalina associada a uma intensa deformação dúctil-rúptil associada a colisões oblíquas no Cambriano Inferior (545 
Ma). A deformação desenvolvida durante o estágio colisional transnordestino seria caracterizada por cavalgamentos oblíquos para NE, em domínios transpressivos entre zonas de cisalhamento dextrais. A transição para o estágio pós-orogênico no Cambriano Superior, seria marcada por magmatismo peralcalino e ultrapotássico associados a regimes distensivos. Segundo Campos Neto et al (1994a e 1994b) o DTRP deve representar uma microplaca com margem ativa à sudeste e, provável margem passiva à noroeste, no final do Esteniano.

Santos (1995 e 1996) descreve a Provincia da Borborema como uma faixa móvel Mesoproterozóica desenvolvida na parte norte do Craton do São Francisco, a qual evoluiu através de um mecanismo de "colagem" de terrenos. O Terreno Alto Pajeú representaria um segmento relativamente jovem, de idade meso a neoproterozóica, enquanto os terrenos de Alto Moxotó e Pernambuco-Alagoas (em parte) possuiriam uma evolução mesoproterozóica, com remanescentes paleoproterozóicos.

Lima et al (1996) obtiveram idades $\mathrm{Rb} / \mathrm{Sr}$ na ordem de $2700 \pm 100 \mathrm{Ma}$, com razão inicial de 0.701 e de $1990 \pm 10 \mathrm{Ma}$, com razão inicial de 0.720 , em ortognaisses bandados do Complexo Floresta, além de um dado KJAr em rocha total em anortosito também no Paleoproterozóico.

Medeiros (1995), a partir de dados de sensoriamento remoto, apresenta um mapa do Domínio Estrutural Central onde os grandes lineamentos e principais corpos graníticos brasilianos são cartografados, sugerindo que o padrão de encurvamento dos fotolineamentos $e$ as formas dos corpos graníticos podem ser utilizados como marcadores cinemáticos. A partir destes dados, observa que os cisalhamentos transcorrentes NE-SW, geralmente, apresentam movimento sinistral e os de direção E-W, dextrais (zonas de cisalhamentos Patos e Coxixola), em concordância com modelo em dominó, proposto por de Jardim de Sá (1995). Medeiros (1995) ressalta ainda o alinhamento de rochas shoshoniticas/peralcalinas ao longo do Lineamento Pernambuco e em uma outra faixa orientada NE, correspondente a sienitoide line de Sial (1986), Ferreira et al (1986), Sial et al (1988) e Ferreira (1991). Os granitóides estudados por Medeiros (1995) caem no campo dos granitóides de arco vulcânico póscolisional, com exceção do Itaporanga, que mostra assinatura geoquímica de granito intraplaca e das peralcalinas tipo Triunfo, que plotam tanto no campo de arco vulcânico como no campo sin-colisional. A maioria das amostras representam suítes calcio-alcalinas/alcalinas de colisão continental, poucas com assinatura geoquímica de arco oceânico-margem continental ativa.

Van Schmus et al (1994 e 1995) interpretam a Província Borborema como parte central do cinturão orogênico Pan-Africano-Brasiliano, formada durante uma convergência neoproterozóica tardia e a colisão dos cratons São Luís-África Ocidental e São FranciscoCongo-Kansai. Subdividem a Província Borborema, com base em dados isotópicos $\mathrm{Sm} / \mathrm{Nd}$ e 
$\mathrm{U} / \mathrm{Pb}$, e em função de sua história pré-colisional em três domínios geotectônicos. $\mathrm{O}$ primeiro, localizado a norte do Lineamento Patos, corresponde aos maciços Rio Piranhas e Caldas Brandão e por supracrustais de idade neoproterozóica. $O$ outro, a sul da província, engloba o Craton do São Francisco e, entre eles, o domínio estrutural central, de evolução mais complexa, que seria constituído por blocos do embasamento paleoproterozóico ou arqueano, alternado com faixas móveis mesoproterozóicas e neoproterozóicas.

Lima et al (1995), com base em dados geoquímicos, subdividem as rochas metavulcânicas da Faixa de Dobramentos Piancó-Alto Brígida (xistos verdes, anfibolitos e gnaisses félsicos) em três grupos distintos de metabásicas e em um grupo de metafélsicas. As rochas metabásicas foram subdivididas em: grupo $\mathbf{A}$, basaltos intra-placas; grupo $\mathbf{B}$, basaltos de cadeias meso-oceânicas e/ou N-MORB; e grupo $C$, basaltos de arco vulcânico. As metafélsicas são alcalinas e subalcalinas, apresentando padrões spidergrams similares às rochas vulcânicas calcio-alcalinas de arco. Observam que os dados geoquímicos sugerem ambiente de back-arc, conforme proposto por Campos Neto et al (1994a e 1994b). Propõem uma evolução a partir de um registro extencional a $1,1 \mathrm{Ga}$, com intrusão de metabásicas do grupo $A$, que se associadas às metavulcânicas alcalinas do grupo $D$ poderiam indicar um vulcanismo bi-modal do estágio rifte. As rochas do grupo B com características de MORB seriam consistentes com uma bacia extensional com contaminação crustal, e algumas destas (metagabro) poderiam representar remanescentes de crosta oceânica. As metabásicas do grupo $C$ e algumas metavulcânicas félsicas do grupo $D$ poderiam representar vulcânismo associado a convergência de placas, pode poderia ter ocorrido a 1,05 $\mathrm{Ga}$.

Almeida (1995) estudando as rochas metamáficas toleíticas de Itatuba (Pb), localizadas na Faixa de Dobramentos Pajeú-Paraiba, provavelmente, originadas por fusão parcial de um manto enriquecido localizado abaixo de uma zona de subducção, identificou uma evolução litosférica complexa, com um estágio de evolução no fácies eclogito, um evento no fácies granulito e um último no fácies anfibolito. A temperatura estimada varia de $726^{\circ}$ a $1185^{\circ} \mathrm{C}$ e a pressão de 4,8 a 8,2 kbars, que representam condiçőes de reequilibro parcial nos fácies anfibolito e granulito, respectivamente.

Brito Neves et al (1995) formalizam a orogênese Cariris Velhos, observada a sul do Lineamento Patos, que compreende um ciclo de Wilson completo iniciado no Mesoproterozóico (abertura) e que se prolongou até o Neoproterozóico (colisão).

Fonseca (1996) descreve a sequência metavulcanossedimentar mesoproterozóica do Complexo Irajaí, próximo ao município de Sertânia, como constituída por paragnaisses com intercalações de anfibolito e mármores (sequência sedimentar), ortoanfibolitos, metatufos (componentes vulcânicos), diques e sills de metagabros e dioritos, e niveis de metachert. Dois 
estágios metamórficos são observados: o mais antigo do fácies anfibolito alto, com temperatura da ordem de $720^{\circ} \mathrm{C}$, e um segundo estágio retrógrado para o fácies xisto verde. Quimicamente os ortoanfibolitos são basaltos a basaltos andesíticos de baixo $\mathrm{K}$, semelhantes aos basaltos toleiitos de arcos de ilhas oceânicas, as metapiroclásticas são semelhantes aos traquitos de alto-K a traquiandesitos, enquanto as rochas metavulcanoclásticas es os metagabro/diorítos são semelhantes as rochas calcio-alcalina de arco de ilha. Os paragnaisses são interpretados como gerados em ambientes de arco, com uma clara contribuição continental.

Sales (1997) estudando as rochas do complexos Irajai (metavulcanossedimentar) e Sertânia (metassedimentar) na área de Afogados da Ingazeira, observa que as análises químicas de rochas metassedimentares indicam uma composição litoarenítica e arcosiana para o primeiro e grauváquica para o segundo, despositados em ambiente de arco vulcânico, sendo que o Complexo Irajai mostraria uma componente subordinada de margem continental ativa. Dados estruturais e de geotermometria e geobarometria indicam que os referidos complexos estiveram em niveis crustais diferentes $\left(650^{\circ} \mathrm{C}\right.$ e $6,5 \mathrm{kbar}$ para o metamorfismo associado a principal fase de deformação, no Complexo Irajaí e de $600^{\circ} \mathrm{C}$ e $3,7 \mathrm{kbar}$ para o Complexo Sertânia. A justaposição destes niveis crustais distintos foi interpretada como associada a movimentação dextral, da Zona de Cisalhamento Afogados da Ingazeira, durante o Brasiliano.

Kozuch et al (1997a e 1997b), estudando rochas localizadas em uma faixa que passa a nordeste de Serra Talhada e a sul da cidade de Teixeira, concluem que a maioria das rochas tidas como embasamento gnáissico representam, juntamente com depósitos metavulcânicos, um mesmo ciclo magmático com idades similares no limite Mesoproterozóico/Neoproterozóico (cerca de 1,0 Ga). Dados de $\varepsilon N d$ sugerem derivação de um manto litosférico enriquecido ou, de uma mistura envolvendo manto empobrecido e crosta enriquecida. Os valores $T_{D M}$ obtidos, segundos os referidos autores, seriam mais sugestivos para a segunda possibilidade. Nova atividade magmática teria ocorrido há cerca de $750 \mathrm{Ma}$ (tufos de Iguaraci), admitindo assinaturas isotópicas para protólitos tipo Cariris Velhos. 


\section{COMPARTIMENTAÇÃO ESTRATIGRÁFICA}

No presente trabalho foram definidos, a partir dos dados estratigráficos e geocronológicos cinco diferentes conjuntos estratigráficos (Fig. 3): Complexo Serra Talhada, Xistos Sertânia, Complexo Riacho Gravatá, Complexo Cachoeirinha e a Sequência Serra do Olho D'Água.

O Complexo Serra Talhada compreende ortognaisses e migmatitos que ocorrem no núcleo, em forma de amêndoa, de uma estrutura antiformal. Constitui-se dominantemente por rochas plutônicas paleoproterozóicas e mesoproterozóicas, intensamente deformadas e migmatizadas no Neoproterozóico. Ocorrem, juntamente com os Xistos Sertânia, no extremo sudoeste da área e no domínio do Alto Teixeira-Terra Nova (Brito Neves et al, 1995). O Complexo Riacho Gravatá, composto por rochas metavulcânicas e metassedimentares mesoproterozóicas ocorre no interior de três amêndoas orientadas nordeste, duas das quais encontram-se separadas pela extensão dextral da Zona de Cisalhamento Jurú e limitadas, a noroeste, pela zona de cisalhamento dúctil-rúptil e lateral dextral Serra do Caboclo. O noroeste da área (entre a Zona de Cisalhamento Boqueirão dos Cochos, a noroeste, que inflete a leste na direção do Lineamento Patos, e Zona de Cisalhamento Serra do Caboclo, a sudeste) é dominado pela faixa de ocorrência do Complexo Cachoeirinha que contem metariolitos e metadacitos neoproterozóicos. A Sequência Serra do Olho D'Água representa um sistema turbiditico que ocorre de forma descontinua no noroeste da Zona de Cisalhamento Serra do Caboclo.

Essas distintas unidades estratigráficas possuem, como traço comum de união, a foliação metamórfica principal, originalmente sub-horizontal. Essa foliação, nas rochas de maior cristalinidade, representa uma estrutura $S 2$ devido ao registro continuo da recristalização mineral organizada nos estádios cedo, sin e tardi-cinemáticos da deformação tangencial. 


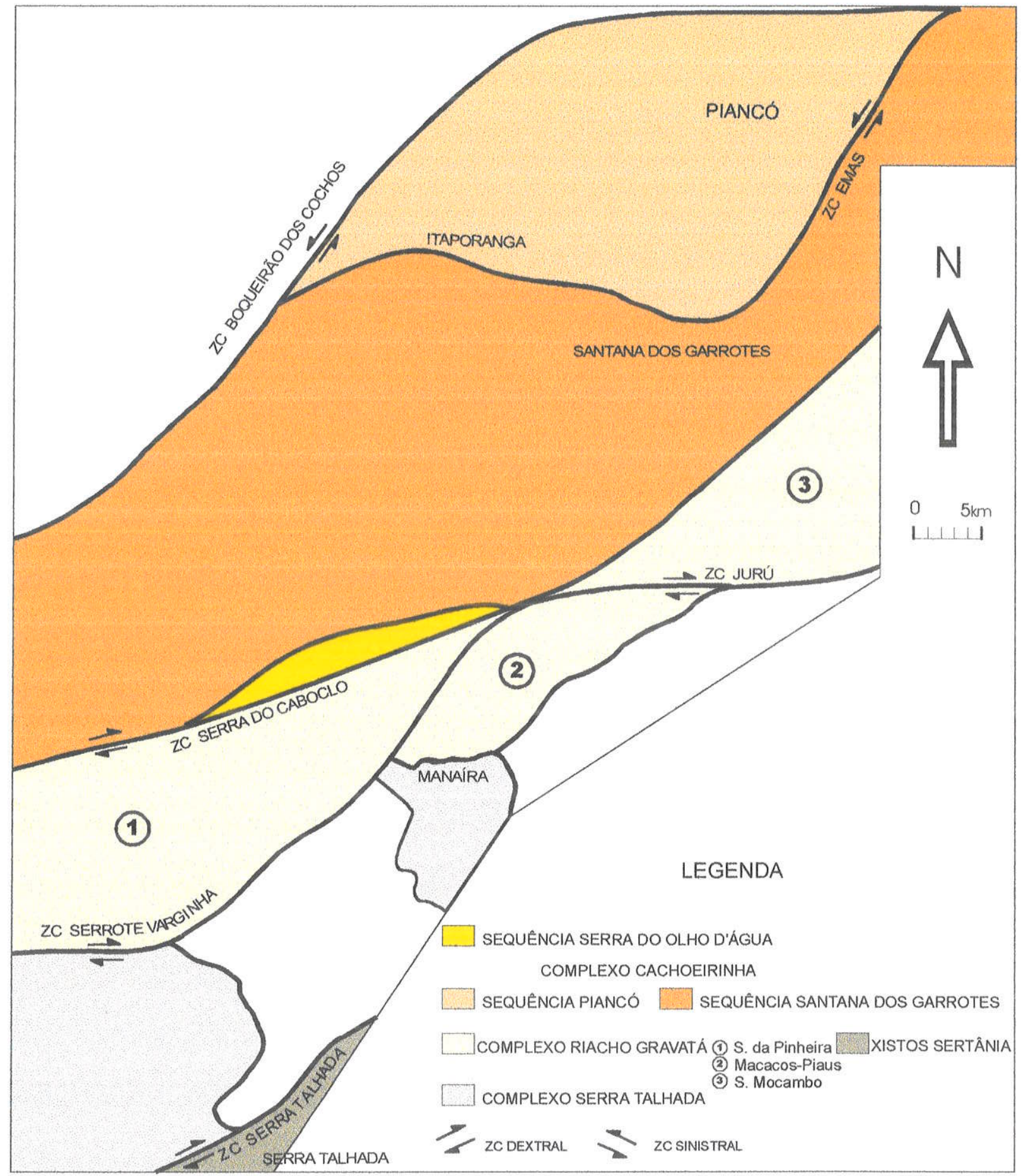

Fig.3) Esboço geológico localizando os terrenos tectono-estratigráficos da Faixa Piancó-Alto Brígida. 


\section{II.1 COMPLEXO SERRA TALHADA}

Os ortognaisses do Complexo Serra Talhada săo rochas acinzentadas (cinza médio e cinza escuro), com textura granoblástica a protomilonítica e granulação média (Foto 1). São biotita granito-tonalito gnaisses contendo bandas lenticulares e decimétricas, locais, de anfibolito (Foto $1 \mathrm{~A}$ ) e um fino bandamento (sub-centimétrico) contínuo e retilíneo a quartzo e plagioclásio de granulação média. Um hornblenda-biotita tonalito gnaisse de granulação média a grossa também ocorre. Corpos alongados, de pouca expressão lateral, de biotita granitognaisse cinza-rosado, com porfiroclástos róseos de feldspato potássico ocorrem tectônicamente paralelos aos ortognaisses. Os ortognaisses apresentam um bandamento estromático sin-cinemático, sub-centimétrico a decimétrico, lenticular e de contornos irregulares, boudinados ou em estruturas tipo pintch-and-swell, composto por um leucossoma quartzo-feldspático emoldurado por um melanossoma e enriquecido em biotitas grossas (Foto 2). Estas estruturas gradam e são invadidas por migmatitos diatexíticos cinza claros, por vezes oblíquos ao bandamento original dos ortognaisses (Foto 1B), guardando restitos de anfibolitos (Foto 3). Xenólitos do granito gnaisse cinza-rosado, porfiroclástico e grosso, com biotita e minerais opacos oxidados, também são frequentes (Foto 5).

Nos gnaisses bandados e migmatitos observa-se uma foliação principal do tipo $\$ 2$, gerada durante o pico do metamorfismo regional, definida pela orientação preferencial de minerais máficos dispostos paralelamente ao bandamento gnáissico. Esta foliação pode estar transposta para uma foliação milonítica de alto ângulo de mergulho relacionada à terceira fase de deformação, penecontemporânea as zonas de cisalhamento transcorrentes.

Os ortognaisses e migmatitos são cortados por: a) hornblenda-biotita granodiorito cinza, de granulometria média a grossa e, foliação de fluxo magmático conferida pela orientação preferencial dos minerais máfico; b) diques de até 5 metros de largura de sienito fino, associado à intrusão do Batólito Triunfo; c) diques centimétricos a decimétricos de diorito fino e de biotita granito fino.

Biotita ortognaisses bandados foram datados pelo método $\mathrm{Rb}$-Sr em rocha total em 2,1 Ga (razăo inicial de 0,7026 ), enquanto que as rochas granito-gnáissicas porfiroclásticas sugerem, pelo mesmo método, valores isocrônicos em 1,0 Ga (Tabela 1- Brito Neves, inédito). Esses valores situam os ortognaisses constituintes deste complexo no Paleoproterozóico (ou mais antigos) e apontam idades mesoproterozóicas para o granito porfirítico.

A anatexia parcial sin-cinemática grada a intensa fusão e geração, sin a tardicinemática, de material diatexítico que engloba xenólitos dos granitos pofiroclásticos. Assim, 
esse processo metamórfico e deformacional, de alto gradiente térmico e gerador de rochas, pode ser correlacionado aos processos neoproterozóicos que precederam as intrusões dioríticas e sieníticas.

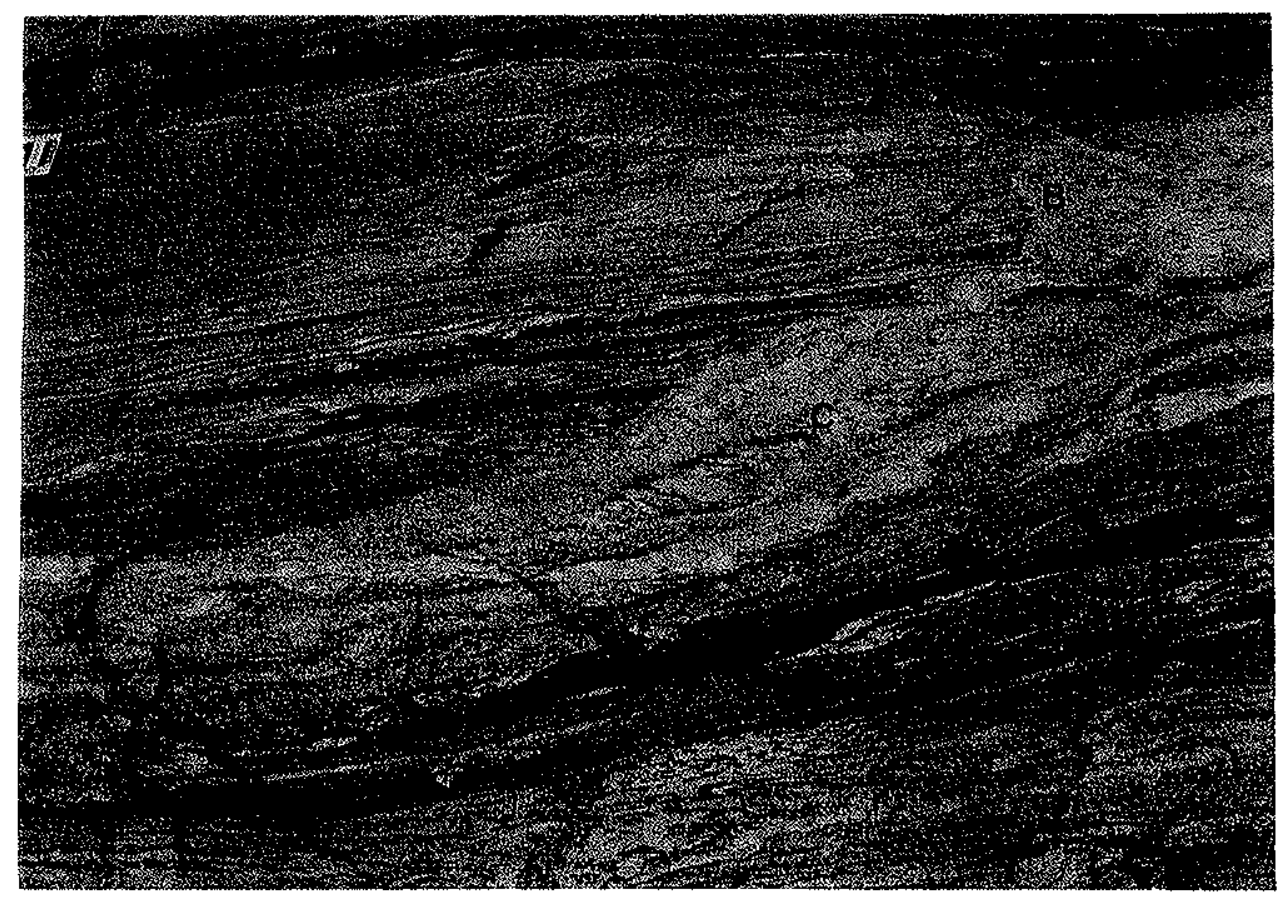

Foto 1) Biotita-gnaisse bandado cinza mostrando niveis anfibolíticos (A) e migmatização. Observa-se em (B) o leucossoma cortando o bandamento do gnaisse. Ocorre ainda schilliren no mesossoma $(\mathrm{C})$. 


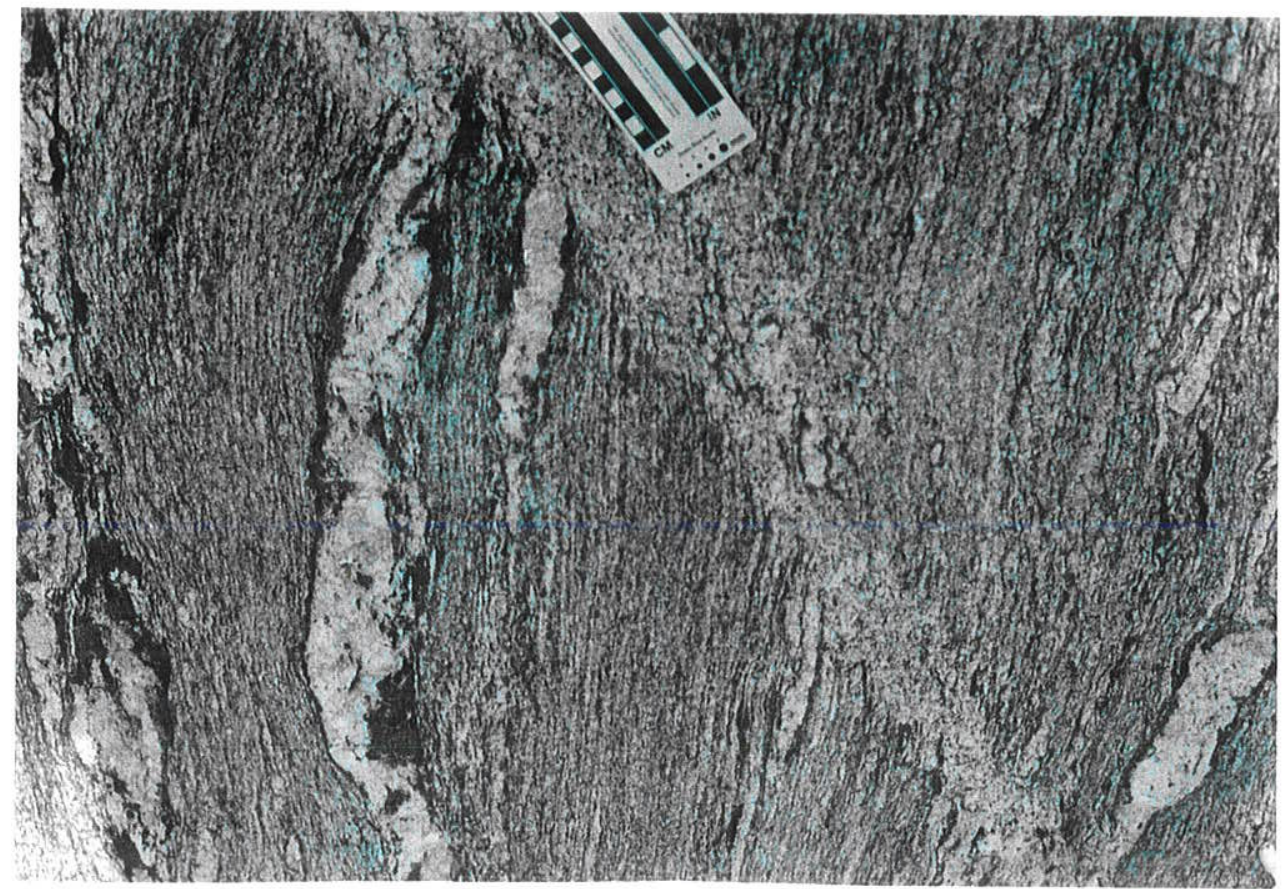

Foto 2) Hornblenda-biotita-gnaisse bandado migmatizado. Placas de hornblenda e biotita mais desenvolvidas são observadas no contato entre leucossoma e o gnaisse. Granito (diatexito) ocorre paralelo A direção da transcorrência (S3).

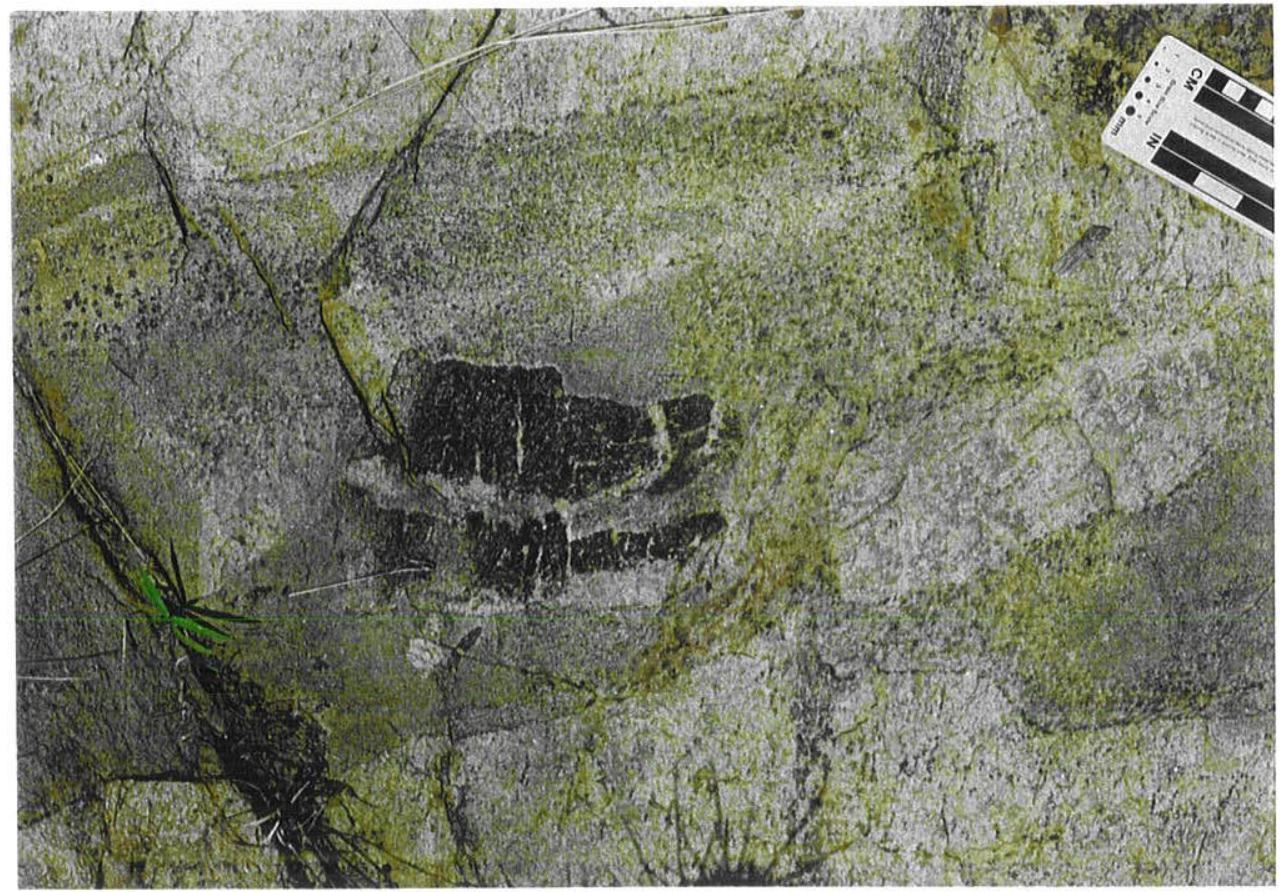

Foto 3) Xenólito (restito ?) da anfibolito em diatexito. 


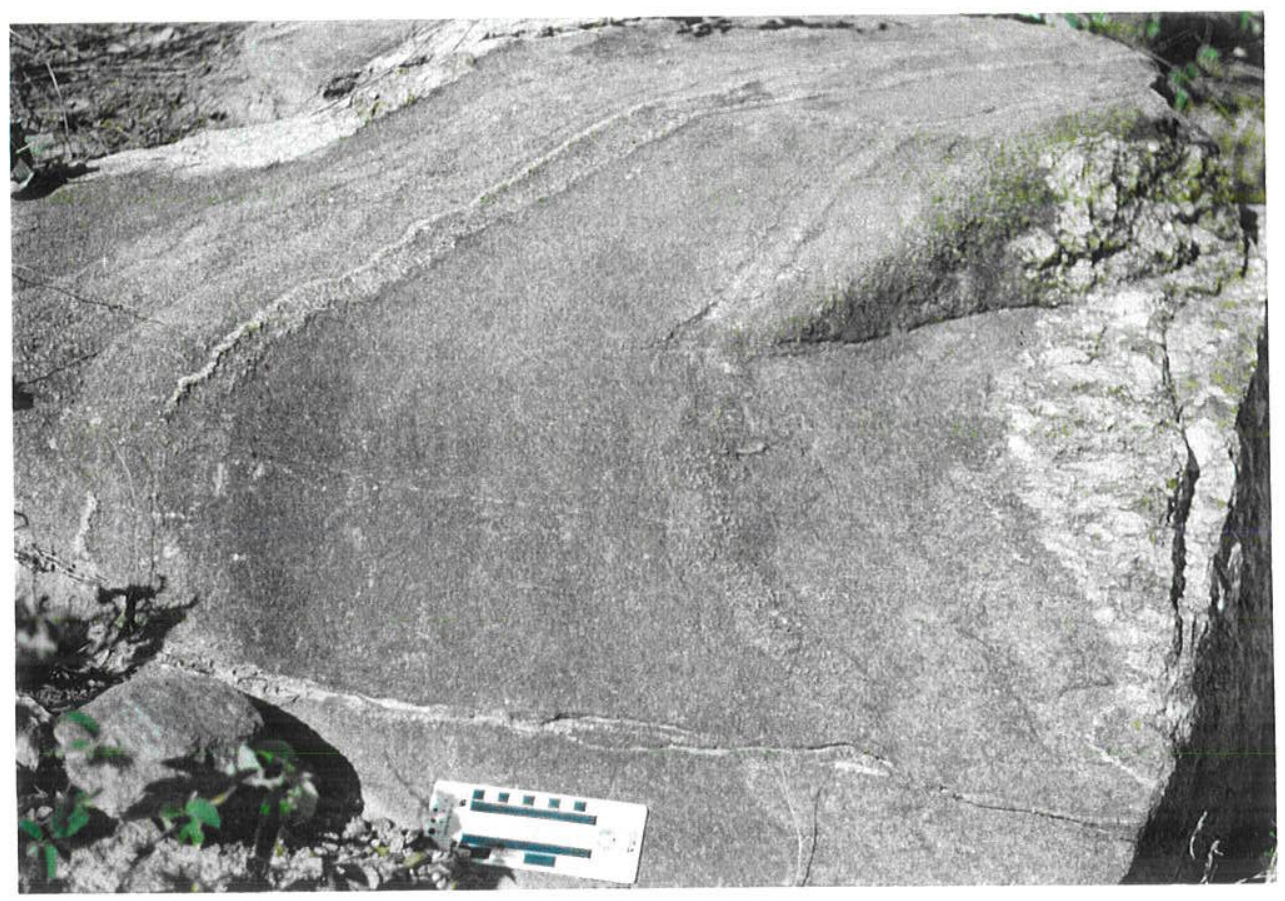

Foto 4 ) Augen-gnaisse em núcleo de dobra da terceira fase de deformação (D3) que dobra o biotita-gnaisse bandado e desenvolve no augen-gnaisse uma foliação S3.

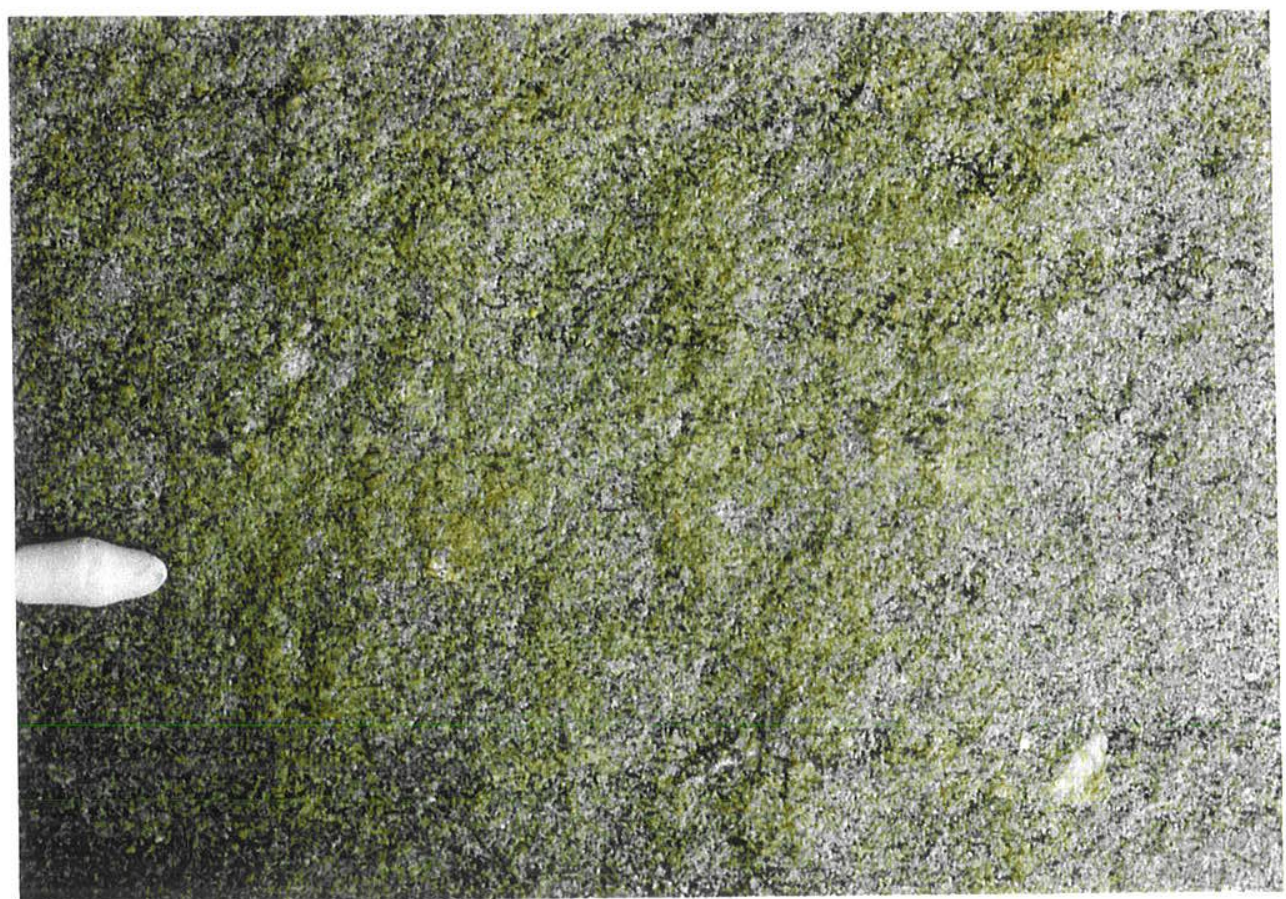

Foto 5 - Diatexito gerado a partir de intensa migmatização dos gnaisses bandados. 


\section{II.2 XISTOS SERTÂNIA}

A noroeste da cidade de Serra Talhada, aflora muscovita-biotita xisto cinza, feldspático e grosso, possivelmente oriundo de metagrauvacas. Veios centimétricos sub-concordantes de quartzo e quartzo-feldspáticos são comuns. Os xistos grauváquicos possuem porfiroblastos centimétricos de granada ricos em inclusões poiquiloblásticas de quartzo, biotita, allanita e de minerais opacos, que nas borda parece sobrecrescer a foliação principal. O plagioclásio no geral é zonado (oligoclásio-andesina) e a biotita sin-cinemática mostra pleocroísmo variando de amarronada a tonalidades marrom-avermeihadas. Apatita, zircão, turmalina e minerais opacos são os acessórios, frequentemente, observados.

Esses xistos afloram na borda sul do Alto Teixeira-Terra Nova e têm suas ocorrências limitadas na área do presente trabalho. Foram relacionados às metagrauvacas do Complexo Sertânia e tidos como contemporâneos ao vulcanismo do Mesoproterozóico Esteniano no sistema de dobramentos Pajeú-Paraíba (Santos, 1995; Brito Neves et al, 1995).

\section{II.3 COMPLEXO RIACHO GRAVATÁ}

O termo Complexo Riacho Gravatá é aqui empregado para designar um conjunto de rochas que ocorre numa faixa de direção NE-SW, limitada a Norte pela Zona de Cisalhamento Serra do Caboclo e a sul pelo Alto Teixeira-Terra Nova. Este complexo ocorre, na área estudada, geometricamente em três amêndoas, limitadas por zonas de cisalhamentos e constituídas por diferentes litofácies, de oeste para leste: Amêndoa Serra da Pinheira, Amêndoa Macacos Piaus e Amêndoa Serra do Mocambo.

O Complexo Riacho Gravatá compreende cinco unidades litodêmicas distintas: unidade $A$, constituída dominantemente por metavulcânicas básicas, às quais podem estar associadas metavulcânicas ultrabásicas, ácidas e intermediárias, metapelitos, metapsamitos, formações ferríferas bandadas (BIF), metacherts e metamargas; unidade B, constituída por rochas metavulcânicas e/ou metaplutônicas de composição ácida a intermediária; unidade C, constituída por metapsamitos e metavulcânicas ácidas, com metapelitos e metatufos subordinados; unidade $\mathrm{D}$, constituida predominantemente por metapelitos e metapsamitos, muitas vezes em alternâncias rítmicas (metarritmitos), com metagrauvacas e metatufos; e a 
unidade $\mathrm{E}$ ou unidade indivisa, assim designada pela ausência de litotipos predominantes. Estas unidades dispöem-se litoestratigraficamente nas diferentes amêndoas.

Datações pelo método U-Pb em zircões em rochas metavulcânicas ácidas (Tabela 2), interpretadas como resultantes de magmatismo distensivo intraplaca (Lima et al, 1996; Accioly, 1994), fornecem idades (intercepto superior) variando entre 930 a $1.100 \mathrm{Ma}$ (Brito Neves et al, 1990; Brito Neves et al, 1995; Kozuck et al, 1997). Isócrona Rb-Sr em rocha total das metavulcânicas ácidas e xistos associados, fornecem idades de $948 \pm 6 \mathrm{Ma}$ (Brito Neves et al, 1995). Esta idade $\mathrm{Rb}-\mathrm{Sr}$ é questionada pelos próprios autores devido a forte dispersão apresentada, mas aceita em função da diversidade dos litotipos utilizados e da coerência com os dados U-Pb em zircões. As idades U-Pb são interpretadas pelos referidos autores, como idade da intrusão associada a um rifte, enquanto os valores $\mathrm{Rb}$ - $\mathrm{Sr}$ foram relacionados a um metamoriismo. Segundo Brito Neves (1995), os dados Sm-Nd em rochas metavulcânicas do Complexo Riacho Gravatá, com idades modelos ( $T_{D M}$ ) variando de 2,08 a $1,7 \mathrm{Ga}$ e $\varepsilon_{\mathrm{ND} 600}$ variando de $-9,6$ a $-10,1$ (Tabela 2), evidenciam um protólito crustal.

\section{II.3.1 Amêndoa Serra da Pinheira}

Esta amêndoa localiza-se na porção oeste da faixa de ocorrência do Complexo Riacho Gravatá, a noroeste da cidade de Manaíra. Neste contexto três perfis litoestruturais (anexos 2, 3 e 4) permitiram a reconstituição da estratigrafia local deste complexo.

No perfil Manaíra-Santana da Mangueira (Perfil A-A', anexo 2) o Complexo Riacho Gravatá encontra-se metamorfisado no fácies xisto verde, zona da biotita, localmente com granada. As unidades litodêmicas A, B, C, D e E sucedem-se ao longo deste perfil, em contatos tectônicos entre si, através de lascas de cavalgamento para SE. Os cavalgamentos foram posteriormente truncados por zonas de cisalhamento de direção SW-NE, dificultando o entendimento do empilhamento estratigráfico.

Na unidade A, com predomínio de metavulcânicas básicas, são descritos xistos finos da aspecto homogêneo, cor esverdeada e xistosidade marcante, frequentemente manganesíferos, constituídos por clorita magnesiana, anfibólios da série tremolita-actinolita, biotita localmente cloritizada, quartzo e plagioclásio podendo conter ainda, minerais opacos muitas vezes associados à titanita (hipidiomórfica a idiomórfica, geralmente), epidoto, apatita, zircão e carbonatos (localmente), que guardam proporções diferentes entre si. O plagioclásio 
de composição albita-oligoclásio ocorre via de regra zonado, em grãos euedrais a subeuedrais (relíctos ígneo ?).

Um tipo especial de metabásica (com composição gabróide), descrito somente na unidade A, ocorre como diques paralelos a foliação principal (S2) e, no geral, apresenta uma deformação mais acentuada nas bordas. Trata-se de uma rocha subvulcânica, de aspecto homogêneo, granulometria média, constituida por augens de anfibólios (tremolita-actinolita), envolvidos por uma matriz composta, essencialmente de plagioclásio, parcialmente alterados. Microscopicamente o "metagabro" apresenta textura nematogranobástica, com cristais microblasto porfiríticos formados por agregados de actinolita e clorita e envoltos numa matriz de plagioclásio, interpretados por Accioly (1994) como pseudomórfos de piroxênio. Além do anfibólio e do plagioclásio ocorrem minerais opacos, titanita, epidoto e mica branca.

As metavulcânicas ultrabásicas ocorrem subordinadamente dentro da unidade A. São xistos finos com tremolita-actinolita podendo conter proporçōes variadas de talco, clorita, biotita e minerais opacos.

As metavulcânicas ácidas a intermediárias descritas na unidade $A$ são xistos e gnaisses de textura, essencialmente, granoblástica e granulometria fina, com plagioclásio (albita-oligoclásio) e, localmente, K-feldspato (por vezes apresentando intercrescimentos micropertíticos), biotita, clorita, titânita, epidoto, zircão, muscovita e minerais opacos. Mostram um bandamento definido por bandas estreitas compostas, essencialmente, por feldspatos e quartzo recristalizados, alternados com bandas de filossilicatos paralelo a xistosidade principal. Também nestas rochas, Accioly (1994) descreve texturas ígneas preservadas, tais como embainhamentro primário em feldspatos hipidiofórficos a idiomórficos. São ainda descritos na unidade A, no perfil Manaira-Santana da Mangueira, rochas metasedimentares: xistos finos com clorita, muscovita e biotita, filito grafitosos, quartzito fino e quartzito ferrífero bandado.

A unidade B, com metavulcânicas e/ou metaplutônicas ácidas, neste perfil é constituída, essencialmente, por gnaisses de granulometria fina a média, cor cinza, bandados centimétricamente, que podem conter porfiroclásticos de plagioclásio, K-feldspatos ou de quartzo (mais raros), envoltos numa matriz de plagioclásio, K-feldspato, quartzo e biotita. Clorita, muscovita e anfibólio da série tremolita-actinolita, também podem estar presentes. Apatita, zircão e minerais opacos são os minerais acessórios que ocorrem em proporções variadas. São anfibólio-biotita gnaisse médio bandado, muscovita-biotita gnaisse fino, magnetita-muscovita gnaisse fino, muscovita-biotita gnaisse fino bandado e granito de aspecto homogêneo, cor cinza, granulometria fina e foliado. A nível microscópico os gnaisses via de regra, apresentam textura granoblástica e blastoporfirítica com cristais de plagioclásio (albitaoligoclásio) elou K-feldspatos (por vezes micropertíticos) de tamanho variando entre $1 \mathrm{~mm}$ a 
$0,5 \mathrm{~cm}$ em média. $O$ bandamento é conferido pela concentração preferencial de minerais félsicos, paralelos a xistosidade principal (S2).

A unidade C no perfil Manaíra-Santana da Mangueira é representada por metapsamitos e metavulcânicas ácidas intrusivas, aflorantes em áreas topográficamente elevadas, desenhando pequenos serrotes na topografia. Os metapsamitos são, predominantemente: quartzito fino laminado, com finas lâminas micáceas; quartzito cinza bandado, com bandas de espessuras centimétricas constituídas por muscovita, biotita e minerais opacos; quartzitos feldspáticos (metarenito lítico); quartzito microconglomerático com turmalina, biotita, muscovita e feldspatos (metarcóseo) e, quartzito com mica verde (fucksita). O quartzo nestas rochas ocorre por vezes como porfiroclástos milimétrico, ora arredondados (grânulos) ora alongados mostrando fortes indícios de deformação. A muscovita ocorre sempre em proporções secundárias ao quartzo, podendo estar dispersa na rocha, ou concentrada em niveis preferenciais, descrevendo um bandamento composicional paralelo à foliação principal. Subordinadamente, são descritas em algumas destas rochas, clorita, turmalina, granada milimétricas, biotita e mais raramente, grãos de feldspatos alterados de até $2 \mathrm{~mm}$, interpretados como grânulos, além de minerais opacos, zircão e apatita. As metavulcânicas ácidas na unidade C são representadas por: "quartzitos feldspáticos" a duas micas, de aspecto homogêneo, com bandamento discreto conferido pela concentração de feldspatos; clorita-biotita gnaisse cinza esverdeado, granoblástico fino, com níveis de poucos centímetros de cor rosada; gnaisse leucocráticos de granulometria fina e foliação marcante. Em algumas destas rochas observa-se, localmente, em lâmina delgada, texturas indicativas de protólito ígneo, tais como, embainhamento primário de K-feldspatos (meta-estável), zonação do tipo normal em plagioclásio e a presença de intercrescimento mimerquítico, além da presença de quartzo e plagioclásio, por vezes hipdiomórficos. São constituídas por plagioclásio (oligoclásio), K-feldspatos, quartzo, com alguma biotita, clorita, minerais opacos, epidoto, zircão e allanita. Associado subordinadamente aos metapsamitos e metavulcânicas ácidas intrusivas da unidade C, ocorrem ainda turmalinito bandado de granulação grossa, filito cinza laminado, localmente contendo granada, filitos grafitosos, e filitos carbonáticos:

A unidade D, constituída por metagrauvacas (vulcanoclásticas?), metapelitos intercalados à metapsamitos (metaritmitos), metapelitos carbonáticos e metatufos, tem como litotipos mais representativos no Perfil Manaíra-Santana da Mangueira, biotita-clorita xisto fino, muscovita-biotita xisto feldspático, filito negro grafitoso, filito cinza, quartzo-filito, sericita filito com porfiroclástos de feldspatos, muscovita-clorita-biotita xisto fino, filitos de cor ocre (máficos?) e granada-bioțta xisto feldspático. Estas litologias ocorrem em intercalações decimédricas até quase métricas mostrando, localmente, um caráter transicional. 
A unidade E, indivisa, que ocorre na porção mais a sul do perfil Manaíra-Santana da Mangueira, é constituída por filito ocre (metavulcânicas básicas), filito cinza algo grafitoso, quartzito micáceo fino de cor cinza, biotita-muscovita xisto fino de cor cinza claro e muscovita biotita xisto feldspático. Neste perfil, a unidade $E$ é de difícil distinção da unidade $D$, em função do nível da exposição e do baixo grau metamórfico.

No Perfil Serra Talhada-Tabuleiro (Perfil B-B', anexo2) as rochas que compõem o Complexo Riacho Gravatá, na parte mais a sul, encontram-se metamorfisadas no fácies anfibolito zona da granada, localmente migmatizadas. Estas rochas foram enquadradas na unidade E, indivisa. São granada-muscovita-biotita xistos de granulometria média a grossa, granada anfibolito, anfibólio xisto, gnaisse médio a grosso bandado, localmente migmatizado; e muscovita-biotia xisto acinzentado intercalado com níveis, que variam de poucos milimetros a dezenas de centimetros, de quartzito micáceo, que constituem metarritmitos (raros e alterados nesta parte do perfil). Granada-muscovita-biotita xistos descritos nesta localidade, apresentam níveis, de poucos centímetros, de quartzo e quartzo-feldspatos subparalelos à xistosidade principal (S2, localmente, transposta para S3). Microscopicamente são constituidos por proporções variadas de quartzo; plagioclásio (albita-andesina) zonados e algo alterados para sericita e epidoto; biotita de cor marrom-avermelhada ora orientada paralela à foliação principal S2, ora como porfiroblástos obliquos à esta; muscovita orientada paralela a foliação principal (em áreas onde não ocorre anatexia). A granada é milimétrica e anédrica, poiquiloblástica apresentando inclusões de quartzo, biotita, allanita, e minerais opacos, e um certo sobrecrescimento à foliação principal. Além desse minerais são descritos turmalina, apatita e zircão.

O gnaisse de granulometria média a grossa bandado é caracterizado por níveis, variando de alguns centímetros a quase um metro, máficos (biotita) e félsicos (quartzofeldspáticos), localmente migmatizados, com concentrações de minerais máficos acompanhando os bordos dos níveis félsicos e remobilizados, os quais ora são discordantes ora subconcordante ao bandamento. Bandas anfiboliticas ocorrem localmente. Este gnaisse bandado estéril é interpretado como tendo origem metavulcânica.

Os anfibolitos, descritos neste perfil dentro da unidade E, são granoblásticos, de granulometria grossa a média e, geralmente possuem bandamento centimétrico. A nível microscópico, apresentam anfibólio, via de regra, com extinção ondulante, podendo ocorrer em grãos hipidiomórficos a idiomórficos, localmente como porfiroclástos. Estes estão orientados e definem a xistosidade principal; possuem pleocroismo verde a verde-claro e podem conter inclusões de anfibólio com pleocroísmo variando de verde-escuro a verde-amarronnado. $O$ plagioclásio (albita-andesina) apresenta-se, via de regra, zonado e orientado segundo a folição. 
Microclina hipdiomórfica é observada localmente. Granada pode estar presente ocorrendo parcialmente alterada para biotita e clorita, e por vezes poiquiloblástica com inclusões de quartzo, epidoto, zircão e, mais raramente, anfibólio. Também ocorrem quartzo e titanita (esta tende a ser arredondada em rochas com granada $e$, em rochas sem granada, variam de hipidiomórfica a idiomórfica), minerais opacos, zircão, apatita, epidoto. A biotita e/ou clorita ocorrem substituindo granada e anfibólios. O carbonato é um produto secundário. Estes minerais ocorrem em proporções variadas, definindo deste um anfibólio xisto até um granadaepidoto anfibolito.

À Norte da localidade de Santa Rita, ainda no Perfil Serra Talhada-Tabuleiro, ocorrem rochas da unidade $\mathrm{C}$ metamorfisadas no fácies anfibolito, zona da granada. Além de metarritmitos, constituídos por muscovita-biotita xisto acinzentado, localmente contendo granada milimétrica, intercalado a bancos milimétricos a centimétricos de quartzito micáceo, ocorrem gnaisse bandado, xisto feldspático a duas micas (metagrauvacas), granadamuscovita-biotita gnaisse e raros níveis anfibolíticos.

O xisto feldspático a duas micas e os gnaisse são microscopicamente constituídos por proporções variadas de: quartzo; plagiociásio, por vezes zonado (albita-oligoclásio); muscovita orientada palalela à xistosidade principal ou, como porfiroblástos, de até $5 \mathrm{~mm}$, obliquos a xistosidade e localmente com kinks; biotita (com as mesmas características) associada à muscovita, granada arredondada (parcialmente alterada para clorita e biotita) e em porfiroblástos, de até $1 \mathrm{~cm}$, contendo inclusões orientadas (minerais opacos e quarzto) que definem uma foliação interna disrupta da foliação externa; sillimanita do tipo fribolita; turmalina zonada; e minerais opacos, os quais chegam a formar porfiroblástos poiquiloblésticos alongados, de até $3 \mathrm{~mm}$, paralelos a xistosidade, com inclusões orientadas de quartzo, apatita anédrica, zircão com bordas arredondadas e epidoto.

Mais para o norte, ainda neste perfil, nas cercanias de Tabuleiro, o grau metamórfico parece diminuir ainda mais, atingindo o fácies xisto verde na zona da granada. Os xistos se tornam mais finos, intercalando-se com niveis de filito cinza grafitoso, de quartzito cinza e com gnaisse bandado de granulometria fina.

No perfil localizado a leste do lugarejo de Água Branca (Perfil C-C', anexo 3) as unidades, apesar de também apresentarem contatos tectônicos, parecem mais preservadas da deformação e permitem, a partir da integração com os dados dos demais perfis, reconstituir um empilhamento estratigráfico para o Complexo Riacho Gravatá na Amêndoa Serra da Pinheira (Fig. 4). Este é constituído na base, por um granada-muscovita-biotita xisto de granulometria média, intercalado com granada-biotita xisto feldspático médio, granadamuscovita-biotita gnaisse, biotita gnaisse bandado centimétricamente, granada-biotita 
muscovita xisto cinza com niveis quartzosos e granada anfibolito, que passam ao topo para fáceis metamorfoseadas em condições de temperatura mais baixa, zona da biotita, com granada ocorrendo localmente. São xistos finos com muscovita, biotita e clorita em proporções variadas, filito cinza intercalado com quartzito micáceo fino e tremolita-actinolita xistos. Estas litologias congregam a unidade $\mathrm{E}$, indivisa, cuja base é desconhecida, mas que apresenta uma espessura aparente de pelo menos $2.500 \mathrm{~m}$. Sobre esta unidade ocorrem tremolitaactinolita xisto homogêneo, clorita-actinolita xisto, epidoto-clorita xisto, titanita-actinolita-xisto, talco xisto, biotita gnaisse fino, filito cinza intercalado milimetricamente com quartzito fino de cor cinza, niveis de formação ferrifera bandada e de metagabros que compõem a unidade $\mathbf{A}$, de espessura aparente local de cerca de $1.500 \mathrm{~m}$. Dentro da unidade A ocorre um nivel descontínuo, de cerca de $400 \mathrm{~m}$, com gnaisses variados que constituem a unidade $\mathrm{B}$. Sobre a unidade A ocorre um pacote, de espessura aparente local de cerca de $500 \mathrm{~m}$, constituido por muscovitarquartzito fino de cor cinza, quartzito com mica verde, quartzito branco intercalado milimetricamente com biotita-muscovita xisto cinza fino, quartzito microconglomerático, quartzito feldspático (metavulcânica ácida), biotita gnaisse cinza fino e homogêneo, biotita gnaisse bandado fino e niveis de turmalinito que conformam a unidade $\mathbf{C}$. Jazendo sobre a unidade $C$, ocorre a unidade $D$, de espessura aparente de cerca de $400 \mathrm{~m}$, descontinua, constituída por biotita-clorita xisto fino, muscovita-biotita xisto feldspático, filito negro grafitoso, filito cinza, quartzo-filito, sericita filito com porfiroclástos de feldspatos, muscovita-clorita biotita xisto fino, filitos de cor ocre, granada-biotita xisto feldspático, intercalados decimétrica à metricamente. Sobre esta unidade ocorre um nivel descontínuo de espessura aparente máxima em torno de $250 \mathrm{~m}$ de gnaisses variados que constituem a unidade $B$. No topo do Complexo Riacho Gravatá na Amêndoa Serra da Pinheira, ocorre outro pacote da unidade A com espessura aparente mínima de $300 \mathrm{~m}$ e topo desconhecido. 


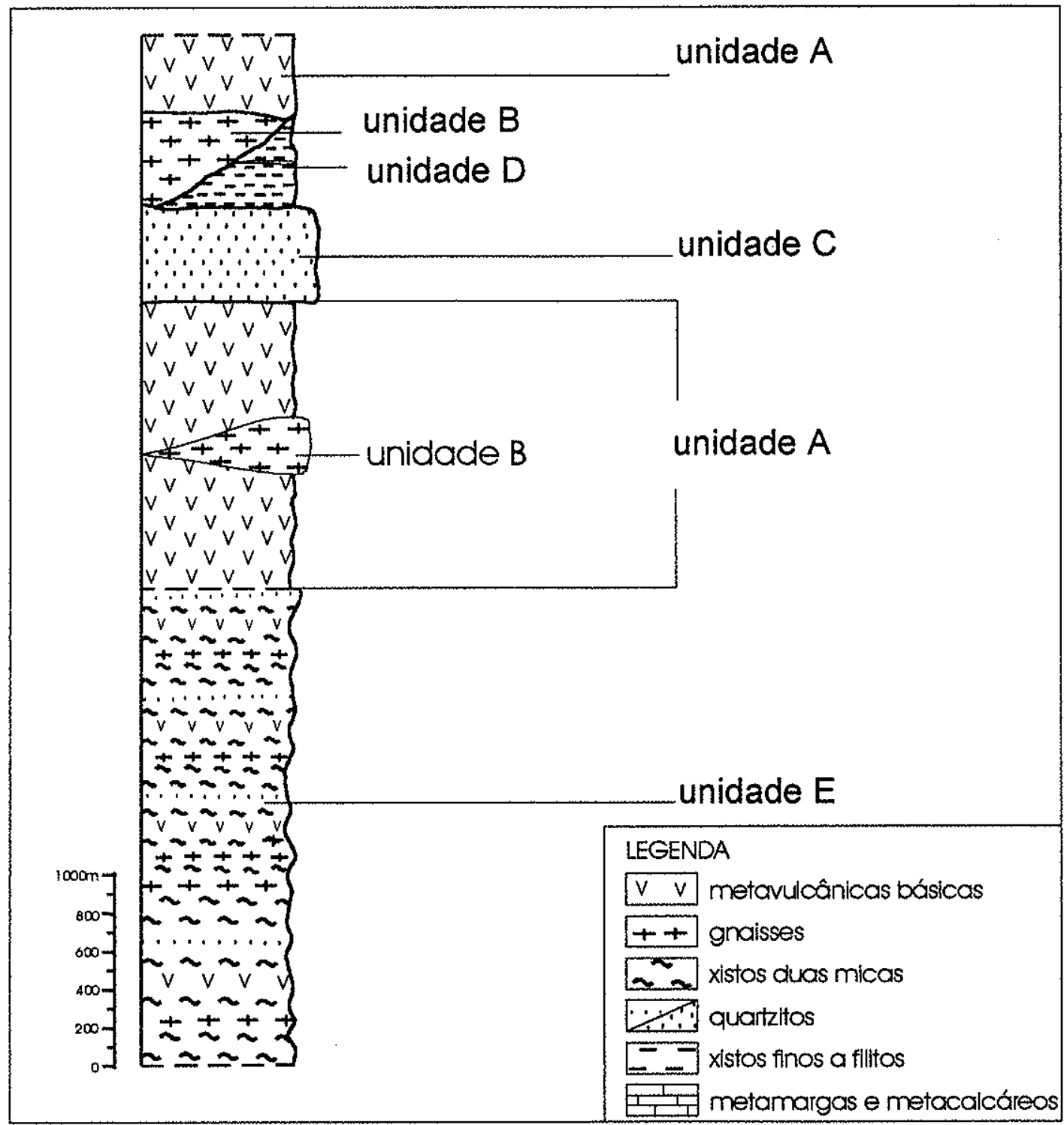

Fig. 4) Coluna estratigráfica do Complexo Riacho Gravatá na Amêndoa Serra da Pinheira (base para o topo): unidade $\mathrm{E}$ (granada-muscovita-biotita xisto de granulometria média, granada-biotita xisto feldspático médio, granada-muscovita-biotita gnaisse, granada-biotita muscovita xisto cinza com niveis quartzosos e granada anfibolitos, que passa ao topo para rochas menos metamórficas: são xistos finos com muscovita, biotita e clorita e granada local, filito cinza intercalado com quartzito micáceo fino e tremolita-actinolita xistos); unidade B (tremolita-actinolita xisto, clorita-actinolita xisto, epidoto-clorita xisto, titanita-actinolita-xisto, talco xisto, tremolita-actinolita xisto homogêneo, clorita-biotita gnaisse fino, filito cinza intercalado com quartzito fino cinza, niveis de formação ferrifera bandada e metagabros); lente da unidade $B$ (gnaisses variados) dentro da unidade $A$; unidade $C$ (muscovita-quartzito fino cinza, quartzito com mica verde, quartzito branco intercalado milimetricamente com biotita-muscovita xisto cinza fino, quartzito microcolglometrático, quartzito feldspático, biotita gnaisse cinza fino homogêneo, biotita gnaisse bandado fino e níveis de turmalinito); unidade $D$ (biotita-clorita xisto fino, muscovita-biotita xisto feldspático, filito negro grafitoso, filito cinza, quartzo-filito, sericita filito com porfiroclástos de feldspatos, muscovita-clorita-biotita xisto fino, filitos de cor ocre, granada-biotita xisto feldspático); nível descontínuo da unidade B (gnaisses variados); unidade A (metabásicas). 


\section{II.3.2 Amêndoa Macacos-Piaus}

Localizada na porção central do Complexo Riacho Gravatá, a norte da localidade de Macacos, a Amêndoa Macacos-Piaus é bem reconhecida ao longo do perfil homônimo (Perfil D-D', anexo 3). A intensa deformação associada a terceira fase de deformação (F3) que transpõe a foliação principal regional $\mathrm{S} 2$ e acaba por degenerar em zonas de cisalhamento transcorrentes, não permitiu a reconstituição da estratigrafia do complexo nesta amêndoa. As litologias aflorantes ao longo do Riacho Gravatá, que empresta o nome ao complexo, foram agrupadas na unidade E, indivisa, que apresenta espessura aparente local de cerca de 5.000 m. São gnaisses finos a médios, bandados centimétricamente, gnaisses finos homogêneos de cor cinza, localmente, cortados concordantemente por veios quartzo-feldspáticos, biotitamuscovita xistos de granulometria média, granada-muscovita-biotita xistos de granulometria média, com vênulas de quartzo paralelas ao bandamento tectônico (S3) metarritmitos, constituidos pela alternância de niveis, centimétricos a decimétricos de quartzito micáceo, e mica xistos, localmente com granada, e anfibolitos com ou sem granada. Estas rochas ocorrem no fácies anfíbolito de pressão alta.

Microscopicamente, os gnaisses são interpretados como tendo origem metavulcânica e/ou metaplutônica ácida, em função da dificuldade de se distinguir os protólitos devido ao grau de deformação/recristalização dos minerais. São gnaisses granoblásticos constituídos por: plagioclásio (oligoclásio) algo alterados; quartzo com extinção ondulante e subgrão; biotitas que ocorrem paralelas à xistosidade ou como porfiroblástos oblíquos (crescimento tardio); muscovita (rara) comumente intercrescida com a biotita; granada ocorre localmente por vezes poiquiloblástica com até $1 \mathrm{~cm}$ de diâmetro, apresentando inclusões de minerais opacos, quartzo e, mais raramente biotita, além de epidoto, apatita, allanita, zircăo e minerais opacos; e clorita, que quando presente, substitui biotita e granada. Apresentam bandamento localizado é definido por concentrações de minerais micáceos, onde a biotita predomina, alternados com níveis quartzo-feldspáticos.

Nos xistos a duas micas, a muscovita e a biotita são volumétricamente proporcionais e definem a foliação principal, ou ocorrem como porfiroblástos (de até $1 \mathrm{~cm}$ ). $O$ quartzo, com fortes sinais de deformação e recuperação, é frequente e a granada, ocorre como porfiroblástos (de em média $1 \mathrm{~cm}$ de diâmetro), contendo inclusões orientadas definindo uma foliação interna (Si), e parcialmente substituida por biotita cloritizada e clorita. Algumas amostras apresentam porfiroclástos de plagioclásio algo alterados, sugerindo tratarem-se de metagrauvacas. Além destes minerais, podem ocorrer minerais opacos (orientados na foliação principal), apatita, turmalina, epidoto, allanita, titanita e zircão. A foliação principal S3, estável na 
zona da clorita, é nesta amêndoa, de baixo ângulo e de terceira geração e transpõe generalizadamente a foliação metamórfica principal regional $\mathbf{S 2}$.

Os anfibolitos têm textura granonematoblástica equigranular, podendo em alguns casos, serem bandados centimétricamente, com o bandamento tectônico paralelo à xistosidade principal. São constituídos por hornblenda (pleocroísmo variando de verde claro a escuro e verde a verde-acastanhado), por vezes zonadas ou poiquiliticas, com inclusões de titanita, minerais opacos, zircão e quartzo. Os grãos de anfibólios estão orientados preferencialmente segundo a foliação principal, ocorrendo localmente, como grãos hipidiomórficos a idiomórficos. O plagioclásio (albita-oligoclásio) ocorre em grãos que variam de hipidiomórficos a xenomórficos, paralelos à foliação principal, via de regra zonados e, parcialmente, alterados para epidoto e sericita. Outras feições texturais dos plagioclásios observadas em algumas amostras são: intercrescimento simplectítico com anfibólio; presença de textura micropertítica; intercrescimento com quartzo (gráfico); e ainda, evidências de deformação/recuperação de grãos. A granada, quando presente, pode ser xenomórfica e, mais raramente hipidiomórfica a idiomórfica. Pode ser poiquilitica, com inclusões de quartzo e minerais opacos, e estar parcialmente substituida nas bordas e fraturas por clorita e/ou biotita cloritizada. O quartzo ocorre em proporções que variam de 5 a $20 \%$, por vezes, orientado paralelamente (neste caso, sendo comum o hábito tabular) à xistosidade principal e associado a feldspatos, definindo o bandamento composicional. Além destes minerais são descritos: minerais opacos, que chegam a ocorrer em porcentagens de até $5 \%$; biotita substituindo, parcialmente, o anfibólio e/ou a granada, via de regra cloritizada; titanita às vezes subédricas, geralmente em íntima associaçăo com os minerais opacos; clorita, substituindo, parcialmente biotita e granada; epidoto (alguns grãos podem ser euédricos); zircão; allanita; apatita; rutilo; e carbonatos (secundários).

Dentro da unidade indivisa pôde-se individualizar um nível de rochas da unidade $\mathbf{A}$, que no perfil apresenta espessura aparente mínima de $200 \mathrm{~m}$. São metavulcânicas básicas (tremolita xisto) associadas a formações ferríferas bandadas e turmalinito, capeados por um nível de cerca de $50 \mathrm{~m}$ de espessura aparente de mármore branco a cinza, com níveis micáceos milimétricos. A unidade A fica mais espessa para sudoeste (próximo a localidade de Manaíra), onde atinge cerca de $500 \mathrm{~m}$ de espessura aparente. São anfibólio xistos a anfibolitos de granulometria fina a média, constituídos por plagioclásio (albita e ortoclásio) via de regra zonados, que tendem a se concentrar em níveis paralelos, descrevendo um bandamento composicional na foliação dominante. Os anfibólios, também orientados, são da série tremolitaactinolita. Pode-se observar mais de uma fase de cristalização: a mais antiga é formada por anfibólios arredondados com pleocroísmo verde-claro a verde-escuro e, a mais jovem, com 
anfibólios de hábito tabular e pleocroísmo verde claro a incolor, orientados oblíquos à foliação principal. Além de anfibólio e plagioclásio são descritos nestas rochas minerais opacos, titanita, epidoto e carbonatos.

\section{III.3.3 Amêndoa Serra do Mocambo}

Dentro desta amêndoa que fica localizada na porção mais a leste do Complexo Riacho Gravatá na área estudada, as litologias descritas estão metamorfoseadas no fácies xisto verde, chegando a alcançar a zona da biotita. Os litotipos principais podem ser observados na parte sul do Perfil Piancó-Tavares (Perfil E-E', anexo 3), onde estruturas sedimentares encontram-se preservadas em niveis metapsamíticos.

A reconstituição estratigráfica (Fig. 5) possibilitou um empilhamento que inicia na base com a unidade D: clorita-muscovita-biotita xisto fino cinza-esverdeado, com niveis quartzosos milimétricos a centimétricos, intercalado com muscovita-sericita filito cinza claro homogêneo e com espessuras até métricas. Definem uma sequência metarrítimica com espessura aparente de cerca de $300 \mathrm{~m}$. Sotoposto, ocorre um pacote descontínuo, de no máximo $250 \mathrm{~m}$, de tremolita-actinolita xisto fino com intercalações, de até poucos metros, de metacherts e de rochas calciossilicáticas bandadas (unidade A). Sobre este nível, ocorre um pacote (500 $\mathrm{m}$ de espessura aparente) caracterizado pela alternância, centimétrica a decimétrica, de niveis metapelíticos e metareniticos semelhantes aos da unidade $D$. Os níveis metareníticos parecem predominar em direção ao topo. São quartzito fino laminado de cor cinza a bege claro, quartzito micáceo fino de cor cinza e filito de cor cinza escuro, que mostram, localmente, contatos gradacionais.

Estruturas do tipo cut-and-fill, isoladas e grosseiramente equidimencionais, com dimensões entre $50 \mathrm{~cm}$ a $1 \mathrm{~m}$, côncavas para cima e com superfícies amalgamadas e cobertas por lâminas argilosas pretas, são descritas neste pacote (Foto 6). Estas estruturas associam-se a niveis laminados plano-paralelos ou com laminações cruzadas de grande porte, aparentemente desenvolvidas por correntes unidirecionais (Foto 7) onde observa-se, lateralmente, estratos com laminações do tipo waves ripples (Foto 8). Apesar das pequenas dimensões, elas podem ser reconhecidas pela seção simétrica e pela presença de lâminas-x bi-direcionais, semelhantes a hummocky cross stratification (Duke et al, 1991).

Segundo Campos Neto et al (1994a e 1994b), algumas das estruturas sedimentares aqui observadas, definem os intervalos de uma sequência turbiditica completa (Bouma, 1962), 
e apontam para uma plataforma, com relevo de fundo irregular e escalonado em direção ao talude continental, onde os depósitos, originados por correntes de turbidez, foram esculpidos pela ação de ondas de tempestades.

Sobre o nível descontínuo da unidade $D$, ocorre um outro pacote da unidade $A$, constituido por tremolita-actinolita xisto fino e calciossilitáticas manganesiferas bandadas, que apresenta espessura aparente média de $200 \mathrm{~m}$. Este é sotoposto por uma sequência rítmica, unidade $\mathrm{D}$, constituida por muscovita quartzito fino e muscovita-sericita-quartzo filito acinzentado (volumetricamente mais abundante), milonitizados e sem estruturas sedimentares preservadas, com cerca de $300 \mathrm{~m}$ de espessura aparente. Sobre este nivel da unidade $\mathrm{D}$ e em contato tectônico, ocorre um pacote de cerca de $600 \mathrm{~m}$ de quartzito micáceo fino e quartzito médio de cor cinza, com imbricações de um biotita-muscovita granitóide milonítico, que é interpretado como da unidade $C$. Segue-se um novo pacote de metarritimitos de cerca de 250 $m$ de espessura aparente, sobre o qual ocorre um outro nível da unidade $\mathbf{C}$, constituido por quarztitos e por biotita-gnaisse homogêneo cinza de granulometria fina, possivelmente tratando-se de metavulcânica ácida. Metarritimitos semelhantes aos anteriores (com $1.200 \mathrm{~m}$ de espessura aparente) ocorrem no topo. Terminando a seção e em contato tectônico (falha de empurrão) ocorrem cerca de $800 \mathrm{~m}$ de granada-biotita-muscovita xisto, granada-biotitamuscovita gnaisse, biotita gnaisse bandado e anfibolitos. 


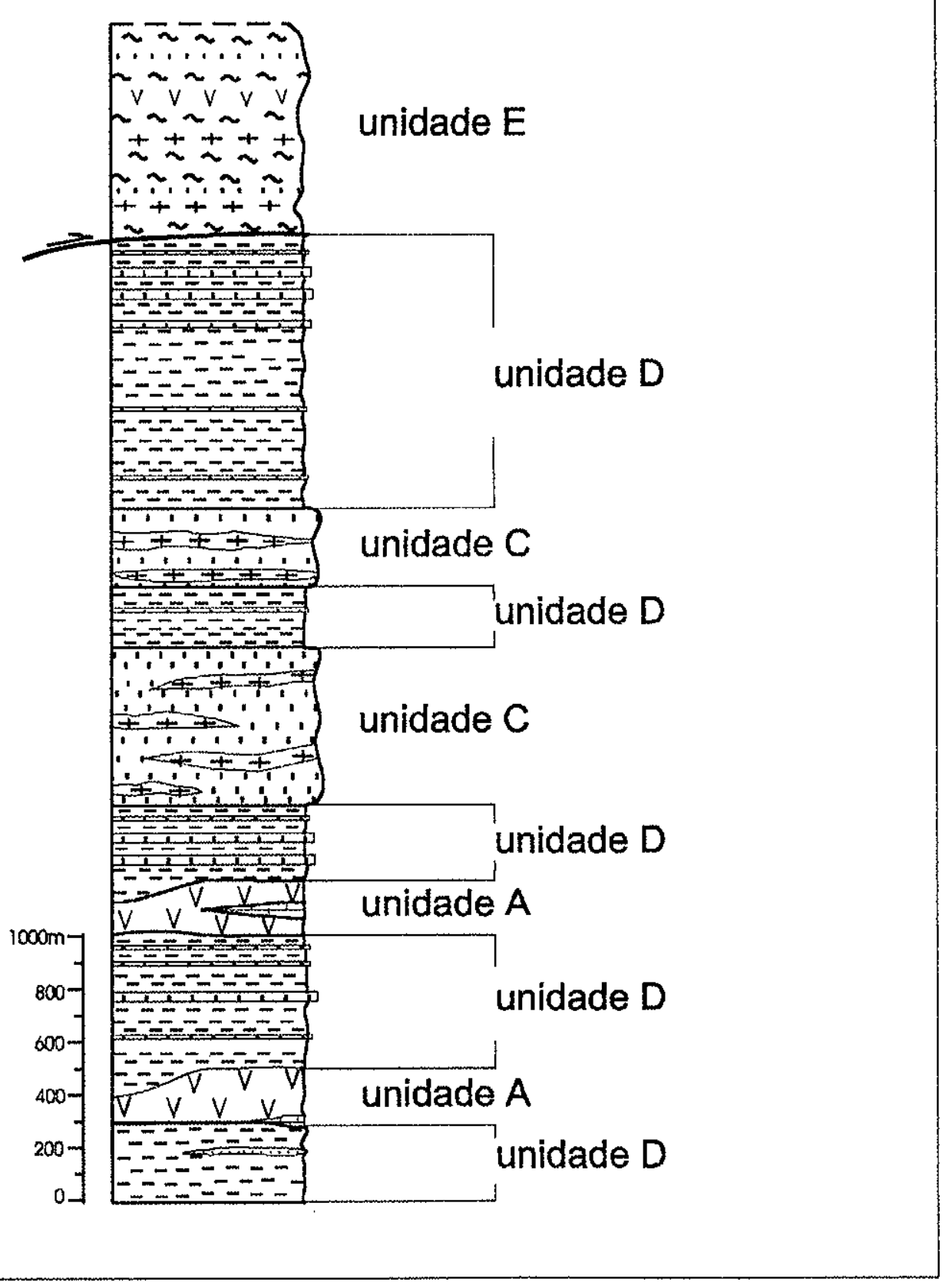

Fig. 5) Coluna estratigráfica do Complexo Riacho Gravatá na Amêndoa Serra do Mocambo (base para o topo): unidade $D$ (clorita-muscovita-biotita xisto fino cinza-esverdeado, com niveis quartzosos e níveis de muscovita-sericita filito cinza claro homogêneo); nível descontínuo da unidade A (tremolita-actinolita xisto fino, metacherts e calciossilicáticas bandadas); unidade D (metarritimitos: quartzito fino laminado, quartzito micáceo fino e filito de cor cinza escuro, com contatos gradacionais e com estruturas sedimentares preservadas); lente da unidade A (tremolita-actinolita xisto fino e calciossilitáticas manganesíferas bandadas); unidade $D$ (metarritimitos: muscovita quartzitos finos e muscovita-sericita-quartzo filito acinzentado); unidade $\mathrm{C}$ (quartzito micáceo fino e quartzito médio de cor cinza imbricados tectconicamente com um granitóide milonitico com biotita e muscovita); unidade $D$ (metarritimitos); unidade $C$ (quarztitos e biotita-gnaisse pouco bandado cinza de granulometria fina); unidade D (metarritimitos); unidade $\mathrm{E}$ (granada-biotita-muscovita xisto, granada-biotita-muscovita gnaisse, biotita gnaisse bandado e anfibolitos). 


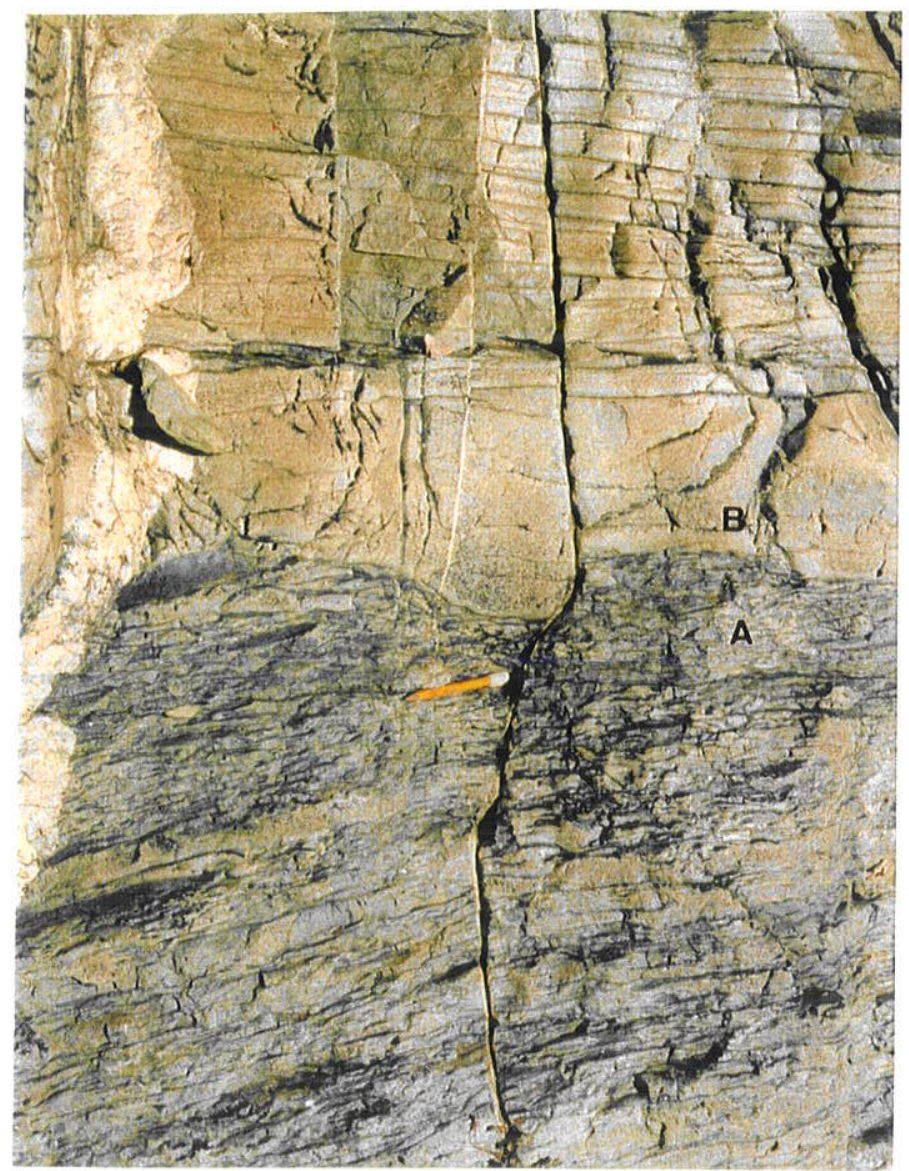

Foto 6) Estrutura sedimentar do tipo cut-and-fill côncava para cima observada em quartzito laminado (A) sobreposto por quartzito médio com grânulo decrescência ascendente $(B)$ do Complexo Riacho Gravatá na Amêndoa Serra do Mocambo. Observa-se veio de quartzo cortando as estruturas.

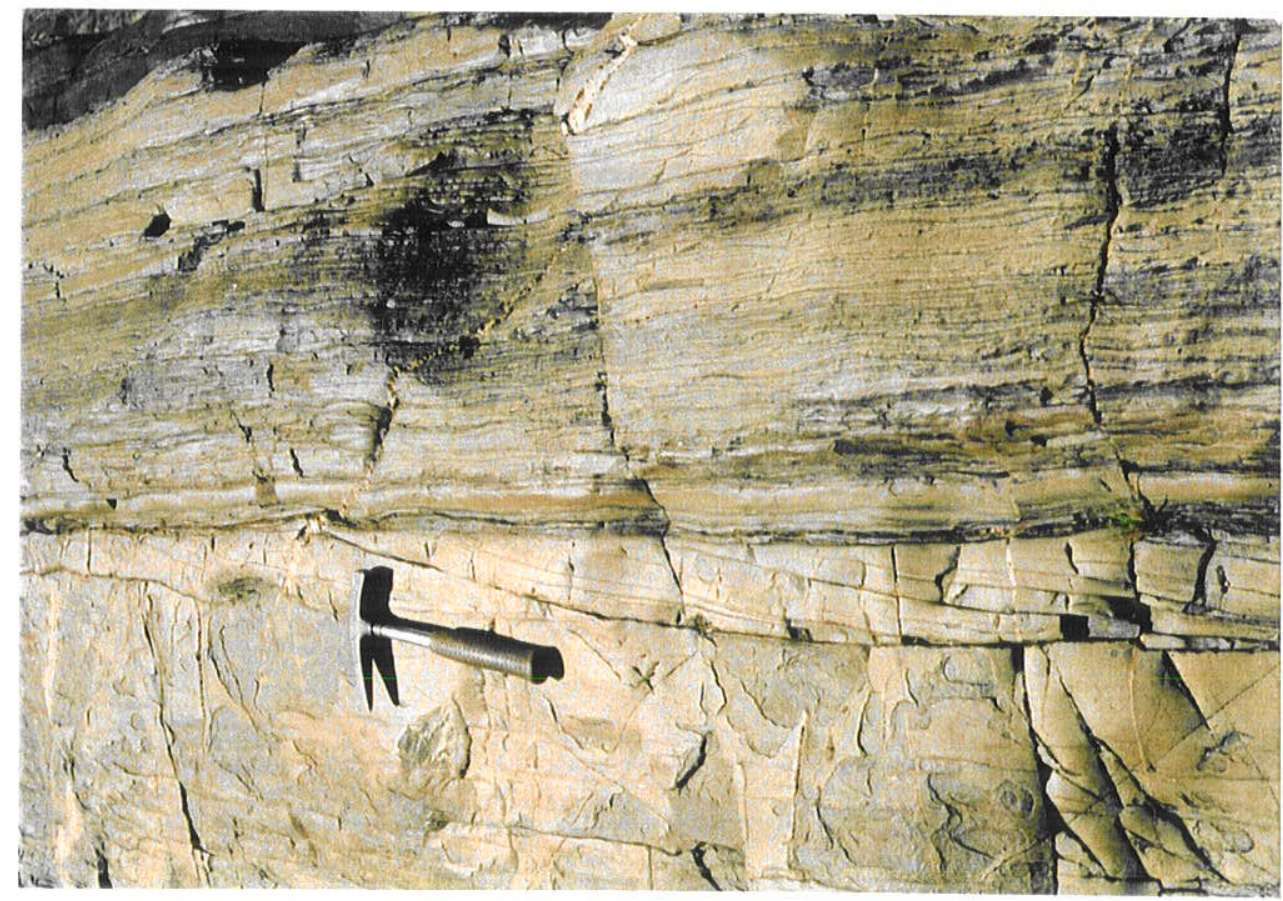

Foto 7) Estratificação cruzada unidirecional desenvolvida em quartzito fino laminado do Complexo Riacho Gravatá na Amêndoa Serra do Mocambo. 


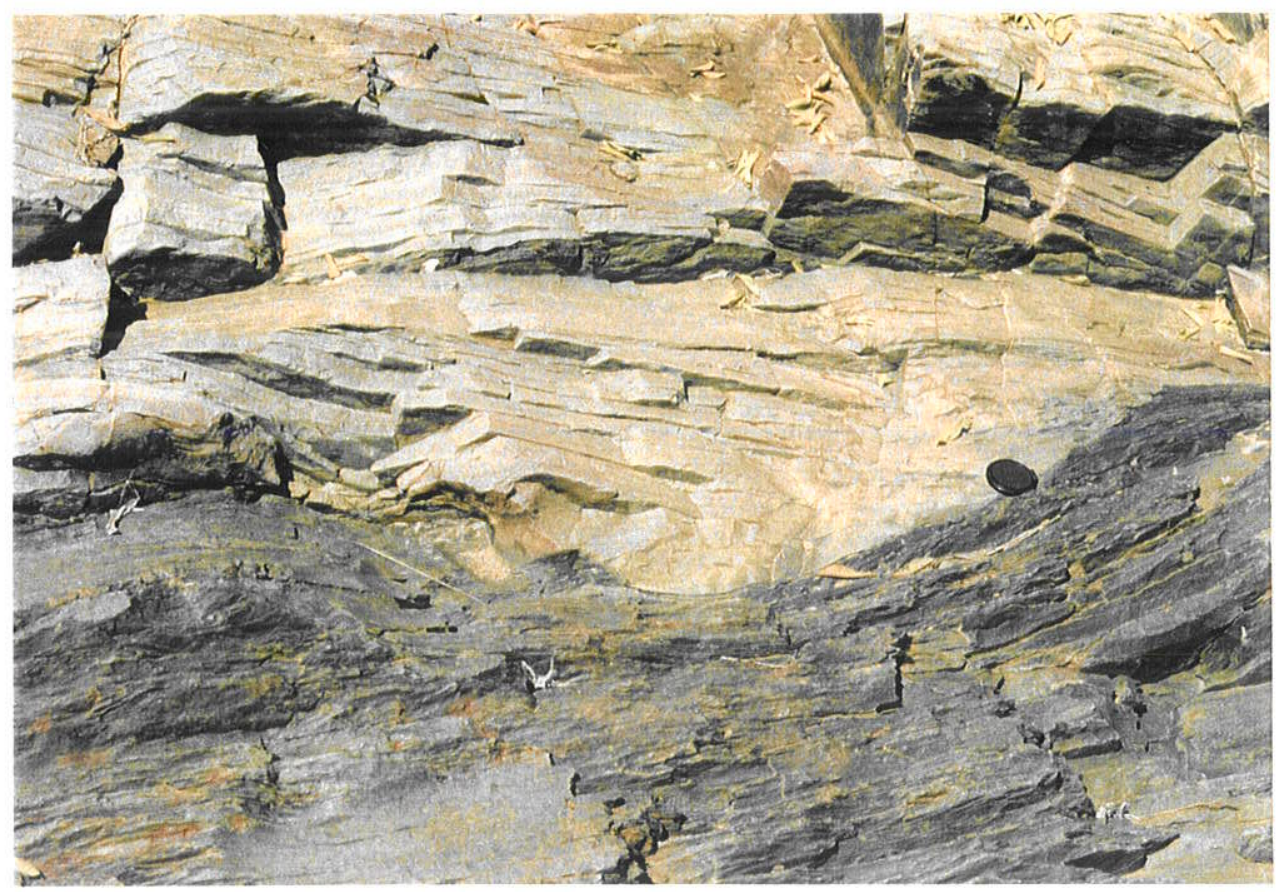

Foto 8) Waves ripples em quartzito fino laminado do Complexo Riacho Gravatá na Amêndoa Serra do Mocambo.

\section{II.4 COMPLEXO CACHOEIRINHA}

Este termo é aqui empregado para congregar litologias que ocorrem entre os lineamentos Patos, Boqueirão dos Cochos e Serra do Caboclo. Podem ser bem identificados ao longo dos perfis geológicos-estruturais Manaíra-Santana da Mangueira, Piancó-Tavares, Itaporanga-Lagoa do Arroz, Piancó-Olho D'Água e Itaporanga-Mata Velha (anexos 2, 3 e 4).

O Complexo Cachoeirinha é constituído, predominantemente, por metapelitos que, localmente, gradam para níveis metapsamíticos impuros de espessuras métricas. Níveis, de até uma centena de metros, de metagrauvacas e/ou metarenito lítico e intercalações métricas de metavulcânicas básicas e metavulcânicas ácidas a intermediárias são descritos, localmente, dentro deste complexo.

Apesar de escassos, os dados geocronológicos situam esse complexo no 
Neoproterozóico. Metavulcânicas ácidas a intermediárias apresentam $T_{D M}$ variando entre 1,01 a 1,51 e $\varepsilon_{\text {Nd600 }}$ entre $-3,4$ e 1,83 e $\varepsilon_{\text {Nd1000 }}$ entre 0,02 e 2,57 (Kozuck et al, 1997; Kozuck, inédito), sugerindo fonte crustal tipo Cariris Velhos para estas rochas. Idades U-Pb em zircőes (Kozuck et al, 1997) nas metavulcânicas ácidas a intermediárias fornecem idades (dacito próximo a Santana dos Garrotes e pórfiro riolito da área da Fazenda Mocambo) que variam de 814 a 750 Ma (intercepto inferior). O $T_{D M}$ (Kozuck, inédito) das metagrauvaca (sillimanita-granada xisto a plagioclásio) de 1,28 Ga e em um xisto máfico de 1,31 Ga, este último com عNd600 de -1,35, são também condizentes com um protólito Mesoproterozóico (Tabela 2).

Levando-se em consideração o conteúdo litológico e o grau metamórfico, o Complexo Cachoeirinha pôde ser dividido em: Sequência Santana dos Garrotes, onde predominam metagrauvacas e metapelitos com intercalações de metapsamitos, metamorfisados no fácies xisto verde alto, e na Sequência Piancó, a norte, onde predominam metapelitos e metapsamitos do fácies metamórfico anfibolito às condições de anatexia.

\section{II.4.1 Sequência Santana dos Garrotes}

Esta sequência é limitada a sul pela zona de cisalhamento dextral Serra do Caboclo, de direção NE-SW e a norte, por uma frente de cavalgamento, de direção E-W, associada a terceira fase de deformação, que passa a sul da cidade de Itaporanga, e inflete para leste na direção NE-SW, passando ai a representar uma rampa lateral.

A Sequência Santana dos Garrotes é constituída biotita-muscovita xistos finos placosos de cor cinza, por vezes cinza-prateado, ora homogêneos, ora bandados, com bandas subcentimétricas de filito grafitoso, e bandas quartzosas. Localmente, são observados grânulos porfiroclásticos esparsos de quartzo e, também, porfiroblástos (de até $2 \mathrm{~mm}$ ) de biotita orientados. Subordinadamente, ocorrem intercalações com contatos gradacionais, entre niveis decimétricos de quartzo-bitotita-muscovita xisto fino placoso e niveis de muscovita quartzito de granulação fina. Estas litologias são constituídas, essencialmente, por quartzo, biotita, muscovita e clorita, podendo conter turmalina, minerais opacos, allanita, epidoto e zircão, além de raras granadas, com até $2 \mathrm{~mm}$ de diâmetro.

Ocorrem espaçadamente, níveis com espessura de até $1 \mathrm{~m}$, de metavulcânicas básicas (xistos finos homogêneos de cor verde) e diques, de até $2 \mathrm{~m}$ de espessura, paralelos a foliação principal (S2), de rochas subvulcânicas e/ou plutônicas deformadas. Estas últimas são constituidas por feldspatos euédricos, biotita, quartzo, muscovita (rara), minerais opacos, 
epidoto e zircão. Este pacote rochoso possui espessura aparente média de pelo menos 3.500 $\mathrm{m}$ (base desconhecida).

$\mathrm{Na}$ área próximo a Zona de Cisalhamento Serra do Caboclo, a Sequência Santana dos Garrotes apresenta níveis metagrauváquicos e psamiticos intercalados com a niveis pelíticos. São xistos finos com biotita, muscovita e clorita, com grânulos de quartzo e feldspatos (algo alterados), quartzito fino impuro com biotita, feldspato alterado e mica branca, filito cinza e biotita-muscovita xisto fino cinza, que se intercalam por cerca de $2.500 \mathrm{~m}$ de espessura aparente.

A passagem para o grau médio, zona da granada em presença da biotita, é bem observada ao longo do Perfil Piancó-Tavares (porção mais a norte do perfil). Clorita-granadamuscovita-biotita xisto acinzentado a cinza esverdeado, de granulação fina a média, e contendo porifiroblástos orientados de biotita, intercala com biotita gnaisse granoblástico inequigranular médio e com porfiroclástos ocelares de quartzo e granada. Veios centimétricos quartzo-feldspáticos e anfibolitos métricos, ocorrem localmente.

Os xistos de granulometria fina a média que predominam no norte da Sequência Santana dos Garrotes são constituídos por quartzo, muscovita e biotita de cor marromesverdeada (parcialmente cloritizada), podem conter localmente granada, clorita, turmalina, minerais opacos (por vezes tabulares), allanita, epidoto e zircão. Biotita, ocorre associada com muscovita e minerais opacos na foliação principal, e também como porfiroblástos tardios (até 2 $\mathrm{mm}$ ), oblíquos a foliação principal e mostrando inclusōes de minerais opacos. A granada, comumente oxidada e/ou cloritizada, ocorre em cristais hipidiomórficos apresentando inclusões de minerais opacos e quartzo, orientadas segundo uma foliação interna Si.

\section{II.4.2 Seqüência Piancó}

A Seqüência Piancó é limitada a norte-noroeste na zona de cisalhamento sinistral Boqueirão dos Cochos e a sul na Zona de Cisalhamento Emas, também sinistral. Estas zonas de cisalhamentos definem uma amêndoa NW-SE associada a terceira fase de deformação regional e gera uma estrutura antiformal de grande comprimento de onda e vergência sul, degenerada em falhas normais (associadas a distensão local) e em falhas de empurrão associadas no flanco inferior (Perfis E-E' e F-F', anexos 3 e 4, respectivamente).

Esta sequência é caracterizada pelo predominio de metapelitos com intercalações de metapsamitos e metagrauvacas, além de niveis métricos de metavulcânicas básicas e ácidas. Possui espessura aparente mínima da ordem de $6 \mathrm{~km}$, e apresenta zoneamento metamórfico 
normal com zonas metamórficas mais profundas, do fácies anfibolito alto, com anatexia localizada no núcleo da antiforme e zonas metamórficas mais rasas, fácies epidoto-anfibolito a anfibolito, nos flancos.

No núcleo da antiforme predominam: granada-muscovita-biotita xisto feldspático, de granulometria grossa a média, com veios de quartzo e quartzo-feldspáticos concordantes a sub-concordantes com a xistosidade, que podem, localmente, conter sillimanita e/ou não apresentarem muscovita, andalusita e cordierita; granada-biotita xisto grosso e acinzentado, com muscovita subordinada e com porifiroblástos poiquiloblásticos de granadas $(3 \mathrm{~cm})$; Granada-sillimanita-biotita-plagioclásio gnaisse cinza e bandado, com bandamento espesso entre o centímetro e o metro, caracterizado pela alternância de niveis cinza-claro mais ricos em plagioclásio e níveis granolepidobásticos mais xistosos, ricos em alumino-silicatos. Também ocorrem intercalações métricas de granada anfibolito, de anfibolito centimétricamente bandado e de quartzito micáceo e localmente granadifero.

Microscopicamente, os metassedimentos são constituídos por plagioclásio (albita a andesina) zonado, localmente alterado, quartzo e biotita paralela a xistosidade ou obliqua (porifiroblástos tardios). A muscovita, quando presente, ocorre sempre em porcentagens subordinadas à biotita e, por vezes, como porifiroblástos oblíquos à xistosidade. A granada, bastante comum nestas litologias, forma porifiroblástos arredondados por vezes poiquiloblásticos, com inclusões de minerais opacos e mais raramente quartzo que podem estar orientadas descrevendo uma foliação interna. Alteração para óxido de ferro e clorita ocorre localmente. Quando zonada, a granada é caracterizada por núcleo repleto de inclusões orientadas e bordos límpidos. A estaurolita, quando presente, ocorre como porifiroblástos hipidiomórficos, zonados, sin a tardi-foliação principal. A sillimanita, descrita em alguns locais, é do tipo fibrolita e ocorre associada a biotita e plagioclásio. Além destes minerais, são observados como acessórios allanita, apatita, zircão, minerais opacos (por vezes em grãos tabulares paralelos à xistosidade), turmalina (zonada) e epidoto.

A passagem para a isógrada da sillimanita, no grau forte e em presença de anatexia, é gradual. Sillimanita-granada-biotita xistos feldspático constitui o mesossoma de um migmatito estromático, cortado por filões e por bolsões de biotita-granito grosso a muito grosso, leuco e hololeucocrático. O leucossoma, de espessura sub-centimétrica a decímétrica, é interpretado como gerado por fusão "in situ", através de reações de quebra de muscovita (ausente no mesossoma desta zona metamórfica) em presença de quartzo e $\mathrm{H}_{2} \mathrm{O}$. Separa-se bruscamente do mesossoma através de um nível melanossomático enriquecido em biotita, tido como resíduo do processo de fusão parcial.

Manifestações magmáticas, comuns na porção.. central do antiforme, são 
aparentemente associadas a anatexia, o que é definido pelas intrusões sub-concordantes a foliação principal S2 (transposta para S3, nas zonas de cisalhamento). São granitos do tipo-S, a duas micas e localmente contendo granada, que ocorrem com dimensões de poucos centímetros à centenas de metros. São granitos leucocráticos a hololeucocráticos, de cor cinza e granulação grossa, com estrutura homogênea, ou, localmente a schilieren de biotita. Venulações e filões de pegmatitos a muscovita e/ou biotita e, mais raramente, granada, ocorrem. Granitóides tipo-Conceição estão presentes nesta amêndoa.

Nos flancos da antiforme (fácies epidoto-anfibolito a anfibolito) afloram granada-biotiamuscovita xisto feldspático, granada-biotita-muscovita gnaisse médio, granada-muscovitabiotita xisto intercalado com niveis de biotita-muscovita quartzito, localmente com granada, raros niveis de anfibolito e tremolita-actinolita xisto.

\section{II.4 SEQUÊNCIA SERRA DO OLHO D'ÁGUA}

Esta sequência ocorre na porção central da área do presente trabalho, numa faixa estreita e descontínua. Está tectonicamente balizada a sul com o Complexo Riacho Gravatá (através da zona de cisalhamento dextral Serra do Caboclo) e a norte (por outra zona de cisalhamento dextral, de menor expressão geográfica) com o Complexo Cachoeirinha. Corresponde a um litofácies conglomerático polimítico (Fotos 9 e 10), de espessura aparente de cerca de $1.200 \mathrm{~m}$ e outro litofácies arenoso a areno-pelítico, de espessura aparente de 400 $m$, bem definidos no Perfil Manaíra Santana da Mangueira (Perfil A-A', anexo 2)

Esta seqüência deposicional representa um depósito orogênico Neoproterozóico relacionado a fase colisional tardia. Esse posicionamento estratigráfico e tectônico, apesar da ausência de dados geocronológicos, baseia-se nas seguintes relaçöes geológicas: a) presença de conglomerados com seixos metamórficos dos complexos Riacho Gravatá e Cachoeirinha; b) foliação metamórfica primária (S1), fortemente oblíqua à estratificação (So) e correlacionável à foliação regional $\mathrm{S3}$, de alto ângulo e, à lineação de estiramento mineral subhorizontal L3. 


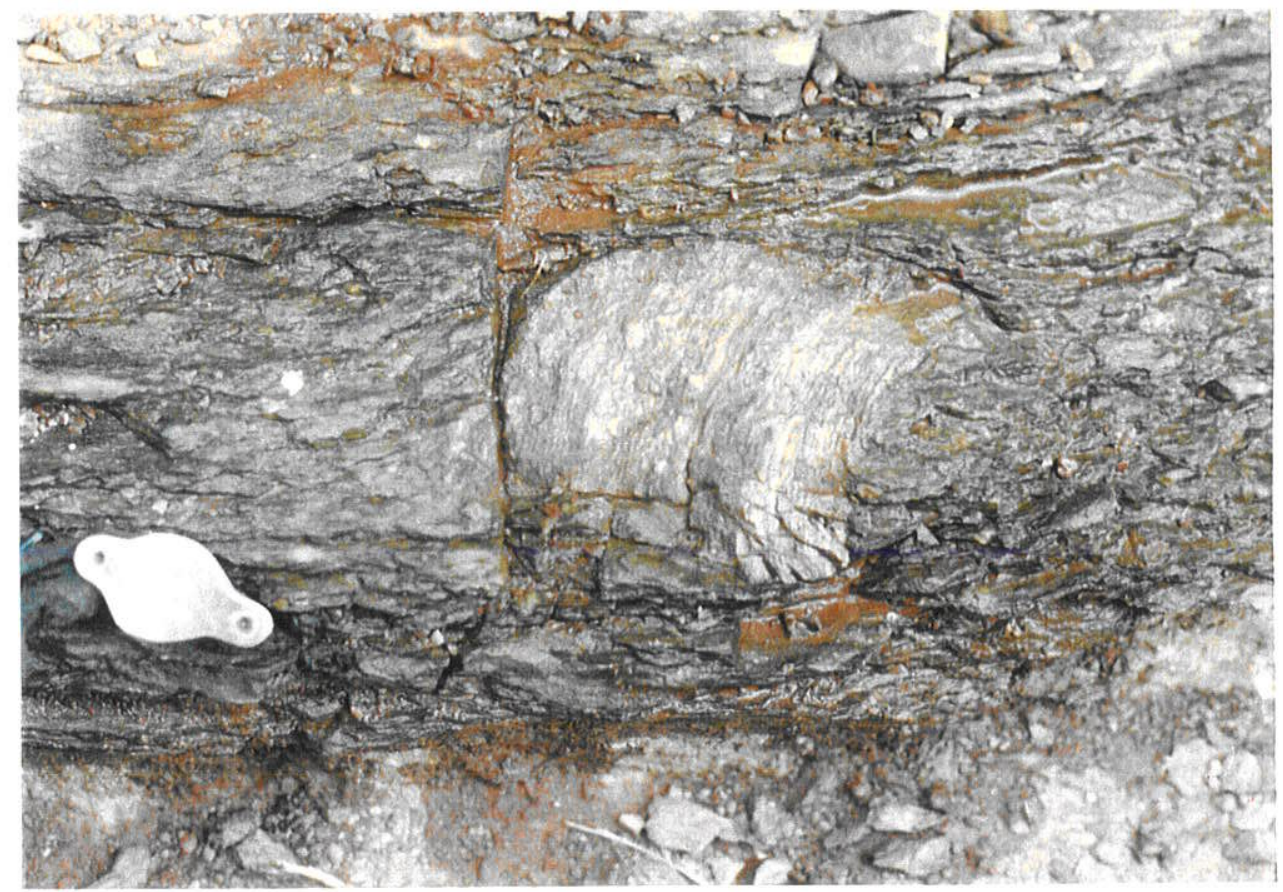

Foto 9) Aspecto do metaconglomerado polimítico da Sequência Serra do Olho D'Água. Observa-se seixo anguloso, com cerca de $15 \mathrm{~cm}$ de comprimento, de metarritimito envolto em matriz metagrauváquica e contendo foliação metamórfica pretérita.

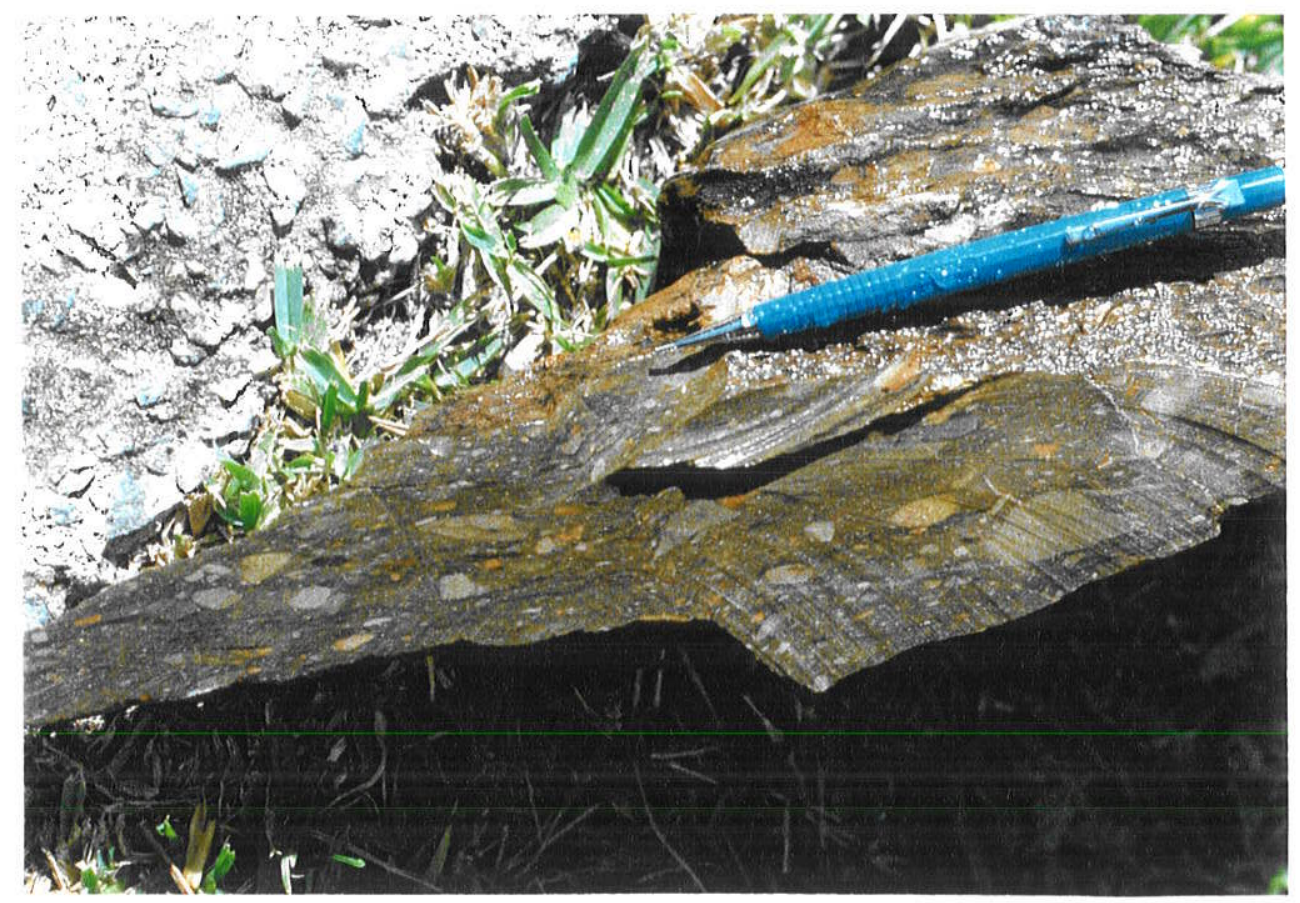

Foto 10) Aspecto geral do metagonglomerado da Sequência Serra do Olho D'Água). Observar seixos angulosos de variadas litologias. 


\section{II.4.1 Litofácies Conglomerático}

O litofácies conglomerático corresponde a metaconglomerados polimíticos, mal selecionados e em camadas com espessura superiores a $1 \mathrm{~m}$, normalmente definidas por uma difusa grânulo-decrescência ascendente. São constituidos por seixos que variam de 1 a $5 \mathrm{~cm}$, chegando a alcançar $50 \mathrm{~cm}$, geralmente arredondados, sub-esféricos a elipsoidais e também angulosos. São seixos de rochas quartziticas e de veios de quartzo e, subordinadamente, de metavulcânicas ácidas (metariolito a metadacito com discreto bandamento paralelo a xistosidade, constituido por plagioclásio, K-feldspato, quartzo, muscovita, biotita cloritizada, titanita, apatita, zircão e minerais opacos), rochas graníticas (biotita granodiorito médio e granito médio a duas micas leucocrático), rochas metabásicas (tremolita-actinolita xisto fino), de metarritmitos (filito cinza laminada, com laminações descontínuas de metarenito fino, com bandamento paralelo a xistosidade), metachert, filito grafitoso, paragnaisses (biotita-muscovita gnaisse com turmalina) e, raramente mármore.

Campos Neto et al (1994a e b) reconhecem da base para o topo (Fig. 6) os seguintes niveis litoestratigráficos: (1) nível basal metaconglomerático, em camadas gradadas, com seixos variando de 5 a $1 \mathrm{~cm}$, em uma matriz de composição metagrauváquica com grânulos, onde predominam seixos de quartzito fino e silicificado e, mais raramente, de granito fino a duas micas, hololeucocrático; (2) ardósia cinza laminada, com laminações descontínuas de metarenito fino e com intercalações subordinadas de metagrauvaca; (3) repetição, por $100 \mathrm{~m}$, do metaconglomerado basal; (4) metaconglomerado, com matriz xistosa e de cor verde, constituída por sericita-clorita gradando para matriz metagrauváquica, com seixos variando de 50 a $2 \mathrm{~cm}$. Os seixos são de quartzito fino, de cor, entrecortado por veios de quartzo, quartzito feldspático bandado, mármore branco de granulação média, quartzito fino com granulometria gradacional e cor cinza-esverdeada, ardósia cinza e quartzito microconglomerático; (5) passa ao topo para um metaconglomerado de matriz microconglomerática, com seixos arredondados e fragmentos angulosos, decimétricos, metarenito gradado de granulação média a muito fina, metarenito fino laminado (plano-paralelas ou convolutas) e ardósia acinzentada; (6) ardósia acinzentada, com poucos metros de espessura aparente.

O litofácies conglomerático, interpretado por Campos Neto et al (1994a e 1994b) como provável depósito por fluxo turbulento de alta densidade (espessuras métricas dos estratos gradados, com grânulo-decrescência ascendente e o volume de metaconglomerados) canalisados em regiões confinadas e de alto gradiente (canyons submarinos). O fluxo turbulento atinge assim, por hidraulic junping (comportamento lenticular, contatos amalgamados e evidências de retrabalhamento), a planície submarina. 


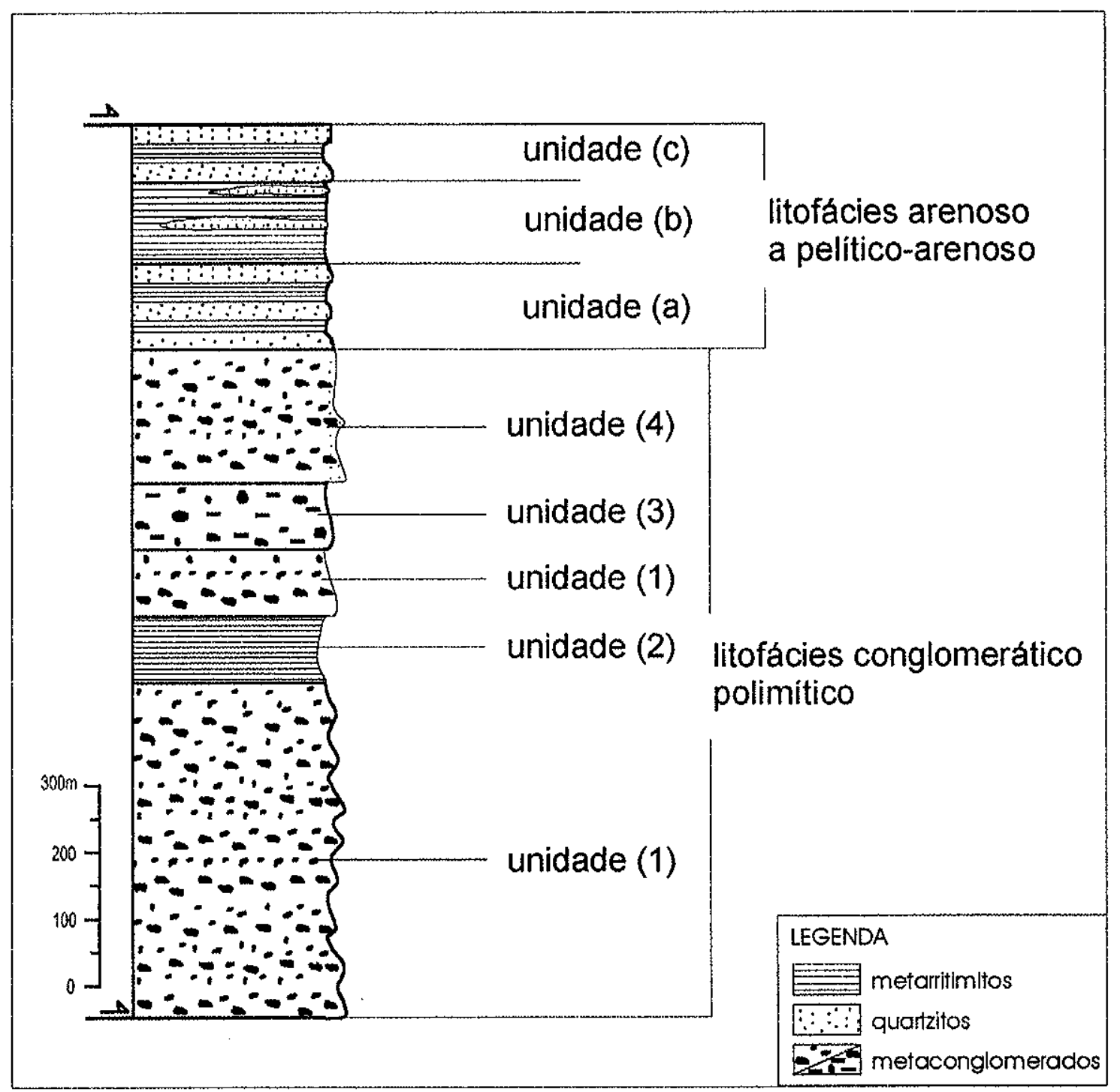

Fig. 6) Coluna estratigráfica da Sequência Deposicional Serra do Olho D’Água, na área homônima (Campos Neto et al, 1994a e 1994b): litofácies conglomerático polimítico basal: (1) metaconglomerado, em camadas gradadas, com seixos variando de 5 a $1 \mathrm{~cm}$, em uma matriz de metagrauvaca com grânulos; (2) ardósia cinza laminada, com laminações descontínuas de metarenito fino e com intercalações subordinadas de metagrauvaca; (3) metaconglomerado com seixos entre 30 e $50 \mathrm{~cm}$ sustentados por metagrauváquica; (4) metaconglomerado com seixos de até $50 \mathrm{~cm}$ em matriz metagrauváquica, que passa ao topo para um metaconglomerado com matriz microconglometática; litofácies arenoso a arenopelítico: (a) alternância de metarenitos com metassiltitos, e filito grafitoso; (b) predominio de uma ardósia laminada, com niveis carbonosos, intercaladas, esparçamente, com bancos decimétricos de metarenito muito fino/metassiltito, que, em direção ao topo, passam a leitos de um metarenito lítico esverdeado; (c) bancos métricos, de estratos gradados, de metarenito lítico e feldspático, com subordinados niveis de metassiltitos maciços, e ardósias bandadas. 


\section{II.4.2 Litofácies Arenoso e Pelítico-Arenoso}

Estes litofácies encontram-se preservados, por cerca de 400 metros, sendo caracterizado, principalmente, por intercalações de níveis quartziticos com níveis pelíticos e mais raramente niveis grauváquicos, onde se observa a presença de estratificação planoparalela que limita estratos com granulo-decrescência em direção ao topo e estratos com fina laminação plano-paralela.

Campos Neto et al (1994 a e 1994 b) descrevem um conjunto basal, de espessura aparente em torno de $150 \mathrm{~m}$, formado pela alternância de metarenito fino, branco acinzentado, gradado em estratos de 30 a $40 \mathrm{~cm}$, com um metarenito muito fino/metassiltito grosso, com laminação plano-paralela, e filito grafitoso cinza escuro, subordinado. Sobre o conjunto basal ocorre, predominantemente, ardósia síltico-sericítica, de cor esverdeada, milimetricamente bandada com níveis cinza escuros sericito-carbonosos e onde, espaçadamente, intercalam-se bancos decimétricos de metarenito muito fino/metassiltito, cinza esverdeado e maciço. Em direção ao topo, ocorrem leitos psamíticos de um metarenito lítico esverdeado. $O$ conjunto superior dos litofácies arenoso e pelítico-arenoso têm espessura aparente da ordem de $100 \mathrm{~m}$ e é caracterizado pela presença de bancos métricos de estratos gradados de metarenito lítico e feldspático, de granulação média a fina, contendo grãos de quartzo policristalino e grãos alongados de material pelítico (com cerca de $20 \mathrm{~cm}$ espessura). Metassiltitos grossos esverdeados e maciços e, ardósias bandadas e laminadas ocorrem localmente. 


\section{SUITES PLUTÔNICAS}

$\mathrm{Na}$ área do presente trabalho foram identificadas seis suítes plutônicas distintas, sendo cinco delas Brasilianas e uma de idade Cariris Velhos.

\section{III.1 SUITES PLUTÔNICAS BRASILIANAS}

Utilizando a classificação das rochas graníticas brasilianas proposta por Almeida et al (1967) para a Província da Borborema, os granitos mapeados na área objeto do presente estudo são: granitos do tipo Conceição, granitos do tipo ltaporanga, granitos do tipo Catingueira (Triunfo), e gabro Taperoá. Além destes, granitos do tipo $S$ são descritos localmente. (Fig. 7)

\section{III.1.1 Granitos Tipo Conceição}

Granitos tipo Conceição são descritos, preferencialmente, a norte da Zona de Cisalhamento Serra do Caboclo (Fig. 7). Constituem corpos de composição granodiorítica a tonalítica, de cor cinza, inequigranulares e de granulometria média a grossa e, subordinadamente, porfiriticos. São constituidos por quartzo, plagioclásio (localmente, como fenocristais zonados de até $3 \mathrm{~cm}$ de comprimento), microclina, biotita, epidoto (magmático), anfibólio e localmente, clinopiroxênio (Cunha, 1996). Enclaves básicos, decimétricos de composição anfibolítica, quartzo-diorítica e clinopiroxênio-diorítica e xenólitos das encaixantes, são comuns em alguns corpos (Foto 11). Sial (1993) interpreta alguns destes enclaves anfibolíticos como xenólitos da rocha fonte basáltica, e outros como autólitos de aglomerados cumuláticos.

Apesar de mineralogicamente tratarem-se de granitos tipo-l, esses granitóides possuem razões iniciais ${ }^{86} \mathrm{Sr} /{ }^{87} \mathrm{Sr}$ elevadas $(0,71263$ a 0,71889$)$, altos valores de $\delta O^{18}(10,12$ a $12,0 \%$ SMOW), são peraluminoso e encontram-se sob condições barométricas de cristalização superiores às das encaixantes. Essas relações sugerem (Sial, 1993) uma origem 


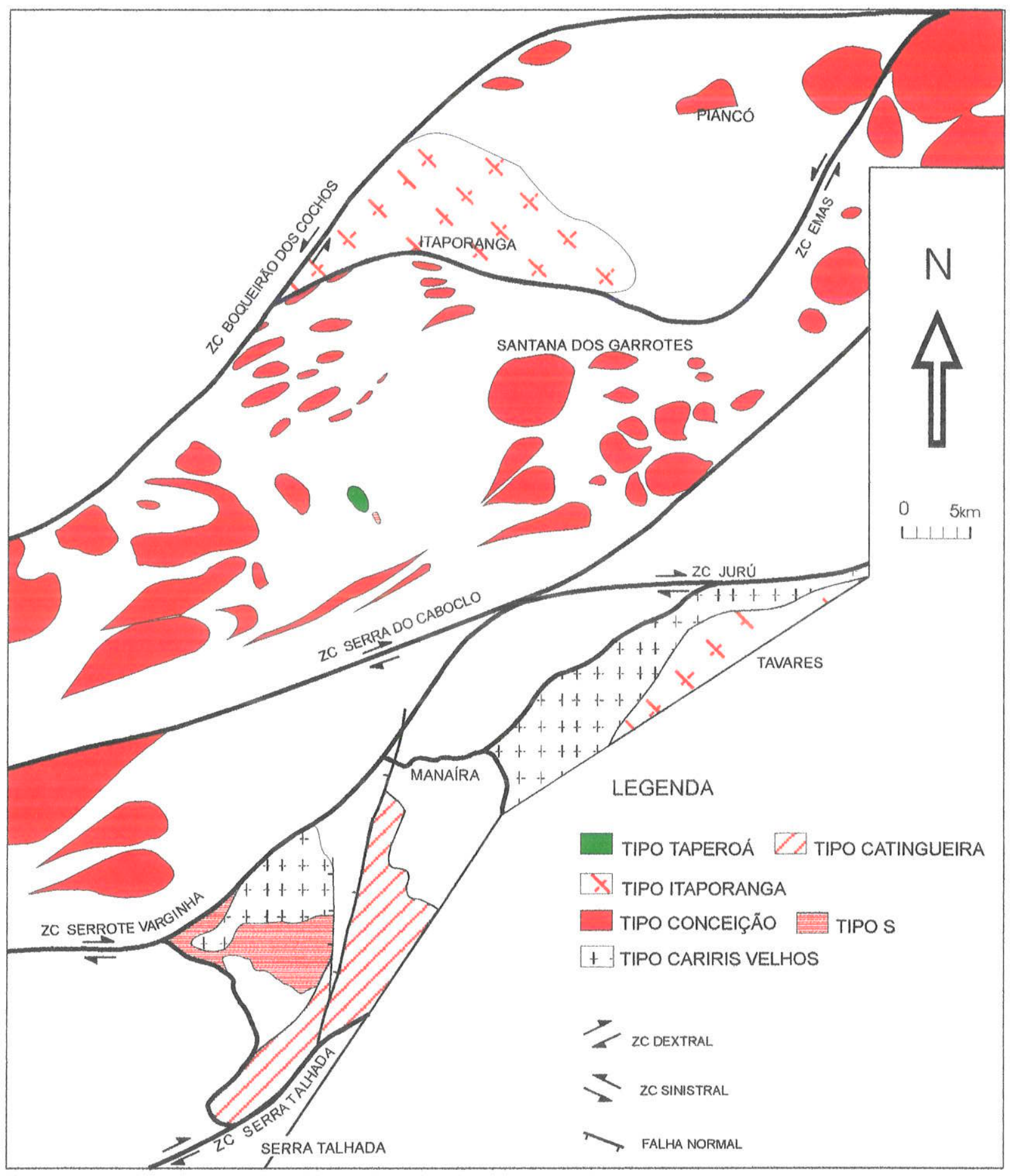

Fig. 7) Esboço geológico localizando as suítes plutônicas observadas na área. 
a partir da fusão parcial de basaltos intemperizados de fundo oceânico, recobertos por uma capa sedimentar. Conclusões semelhantes foram obtidas com base em estudos litogeoquímicos e de isotopia de oxigênio, por Medeiros (1995).

Granitos tipo Conceição na área estudada, afloram segundo três modos distintos: (1) como corpos irregulares com foliação sub-horizontal, dada pela orientação preferencial de minerais máficos e feldspatos, relacionados a pequenos empurrões tardios e associados a terceira fase de deformação (exemplo: o corpo de Santana da Mangueira); (2) como corpos alongados e descontínuos, controlados por zonas de cisalhamentos subverticais associadas a terceira fase de deformação, que imprimem na rocha uma foliação (exemplo: os plutons que ocorrem a sul da cidade de ltaporanga e os plutons localizados a norte da localidade de Santa Rita) e (3) corpos arredondados não deformados ou com deformação localizada, geralmente, posicionados próximos as bifurcações de zonas de cisalhamentos transcorrentes (exemplo: Olho D'Água, Emas e Pedra Branca), que aparentemente propiciaram abertura para o posicionamento passivo destes granitóides (zonas de transtração).

Dados U.Pb (Tabelas 3 e 4 ) em zircōes (granito localizado à norte da Zona de Cisalhamento Serra do Caboclo) forneceram idades de $620 \pm 10 \mathrm{Ma}$ (Van Schmus, inédito). Dados ${ }^{40} \mathrm{Ar}^{39} \mathrm{Ar}$ (Dallmeyer et al, 1987) em horblendas encontram-se em torno de $618 \pm 27 \mathrm{Ma}$ e em biotitas há $603 \pm 17 \mathrm{Ma}$ (corpo a norte de Conceição). Esses dados sugerem uma taxa de resfriamento aproximada em torno de $23,5^{\circ} \mathrm{C} / \mathrm{Ma}$.

Dados Sm-Nd (Kozuck, inédito) nos granitóides Emas e Nova Olinda forneceram $T_{D M}$ entre 1.23 e $1.41 \mathrm{Ga}$, com $\varepsilon_{\mathrm{Nd} 600}$ ligeiramente negativo $(-1.23$ a -2.03), indicando como protólito uma fonte crustal de idade mesoproterozóica (Tabela 3 e 4). Para os granitos localizados a sul da Zona de Cisalhamento Boqueirão dos Cochos (entre as cidades de Serra Talhada e Santa Rita), os dados Sm-Nd encontram-se com $T_{D M}$ entre 2.3 e $2.4 \mathrm{Ga}$ e $\varepsilon_{\mathrm{Nd} 600}$ extremamente negativos (-15.95 e -18.44), indicando um protólito crustal mais antigo, Paleoproterozóico (Tabelas 3 e 4). 


\section{III.1.2 Granitos Tipo Itaporanga}

$\mathrm{Na}$ área do presente trabalho foram descritas três ocorrências de granodioritos porfiríticos com fenocristais de K-feldspatos com até $10 \mathrm{~cm}$ de comprimento, tidas na literatura como granitos do tipo Itaporanga (Almeida et al, 1965): ○ Batólito Itaporanga, Batólito Tavares e o Batólito Princesa Isabel (Fig. 7).

O Batólito Itaporanga, localizado na porção norte da área do presente trabalho, intrusivo no Complexo Cachoeirinha dentro Seqüência Piancó, é limitado pelas zonas de cisalhamento sinistral Boqueirão dos Cochos, a noroeste, e por uma bifurcação desta, também sinistral, a sul. Tem composição granodiorítica a tonalítica, cor cinza médio e granulometria grossa. É constituído por quartzo, plagioclásio, K-feldspatos, biotita, hornblenda e clinopiroxênio (raro). Os feldspatos potássicos chegam a formar fenocristais de até $10 \mathrm{~cm}$ de comprimento, localmente, formando cumulatos (Foto 12) e/ou mostrando orientação preferencial paralela aos minerais máficos (Foto 13). Esta foliação fraca pode ser observada na porção sul do Batólito Itaporanga, onde uma zona de cisalhamento sinistral bordeja o corpo. Nas proximidades da Zona de Cisalhamento Boqueirão dos Cochos, a deformação é mais intensa e atingiu até os estádios pós-cristalinos.

Mariano (1989) interpreta o Batólito Itaporanga como resultante de processos de mistura de magmas de composição quartzo monzonitica a monzogranítica e diorítica potássica. Estimou um paleogradiente térmico de $30^{\circ} \mathrm{C}$ para a área. Para esse autor, o nível atual de exposição corresponde a zona de raiz de um diápiro, posicionado em aberturas tipo pull-apart de falha transcorrente (Zona de Cisalhamento Boqueirão dos Cochos).

Sial et al (1981) consideram os granitos tipo-Conceição e tipo-ltaporanga, intrusões diacrônicas, ou em distintos niveis crustais, a partir de uma mesma fonte magmática.

Medeiros (1995), observa que os granitos tipo Itaporanga possuem composição calcioalcalino potássica e assinatura geoquímica compatível com granitos intraplacas, considerando-

os como granitos tipo-l e provenientes de fonte mantélica ou de crosta inferior $\left(\delta O^{18}<10 \%\right.$ SMOW).

Os batólitos Tavares e Princesa Isabel, localizados a sudeste da área estudada, são intrusivos em ortognaisses e migmatitos do Alto Teixeira-Terra. São considerados como tipoItaporanga por apresentarem composição mineralógica e texturas semelhantes a este. Nestes últimos, sinais de deformação são menos comuns. No Batólito Tavares, estruturas de fluxo convectivo e cumulatos de fesdspatos são feições comuns o (Foto 15). 


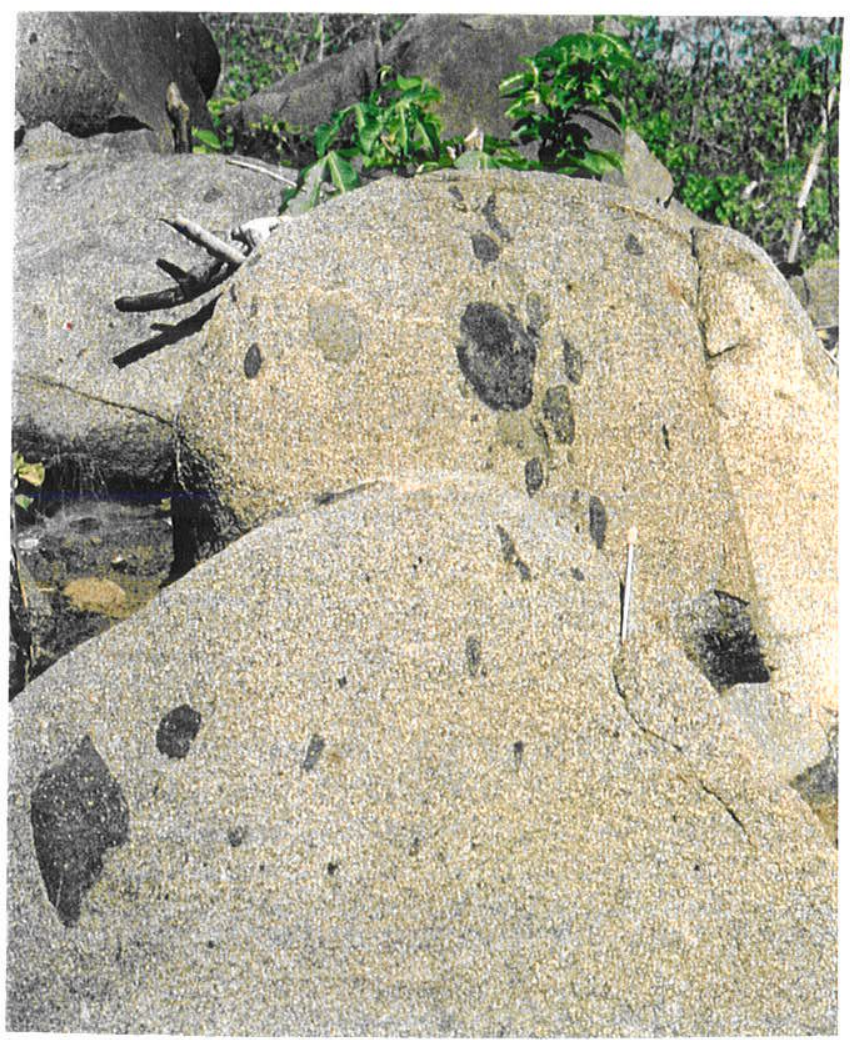

Foto 11) Granito tipo Conceição, localizado a sul de Santana dos Garrotes. Observa-se enclaves básicos ligeiramente alongados e orientados segundo a foliação magmática, dada pela orientação preferencial de fenocristais de feldspatos e minerais máficos.

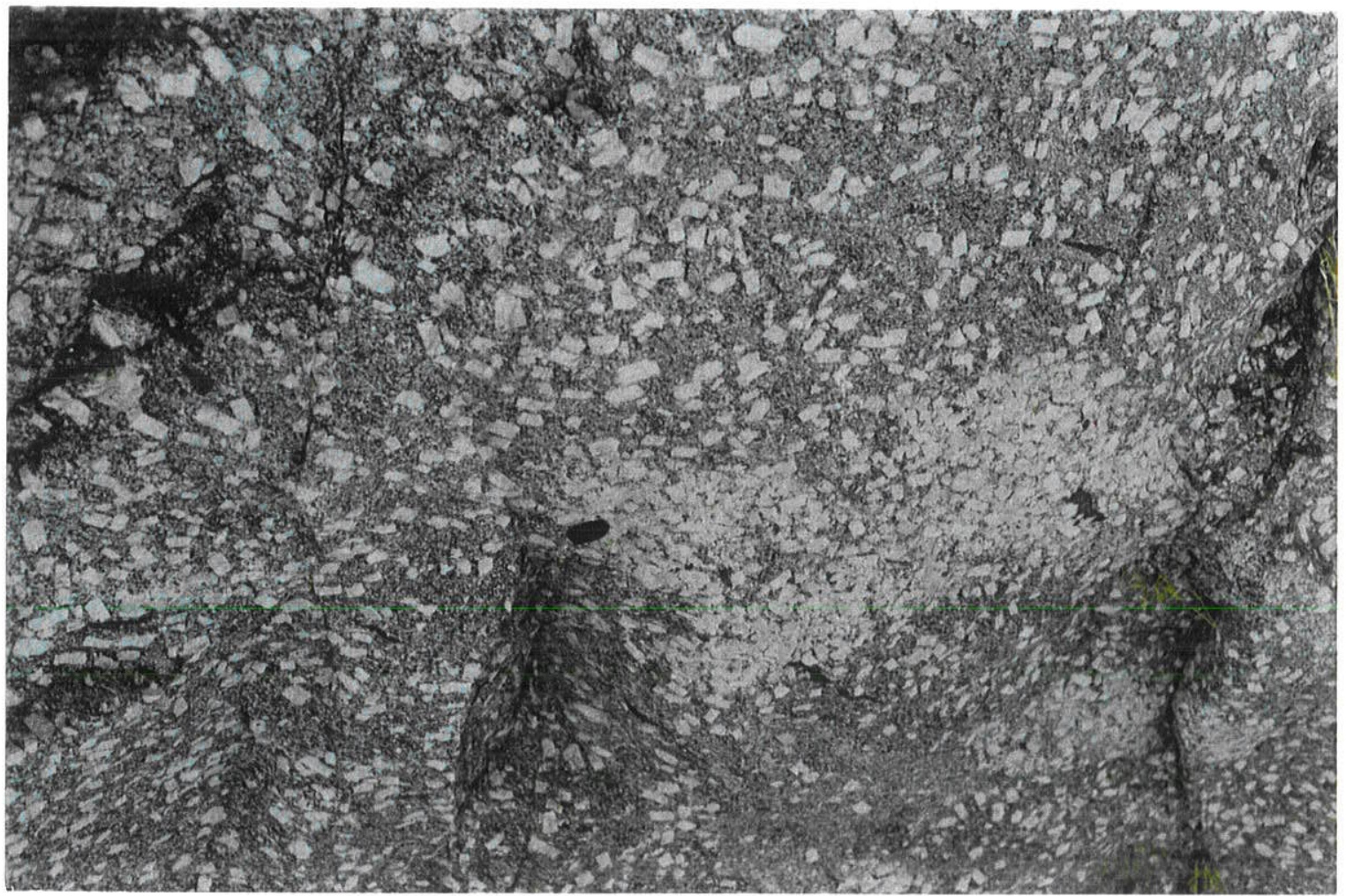

Foto 12) Afloramento do granito Itaporanga, localizado a este da cidade homônima, mostrando cumulatos de fenocristais de K-feldspato. 


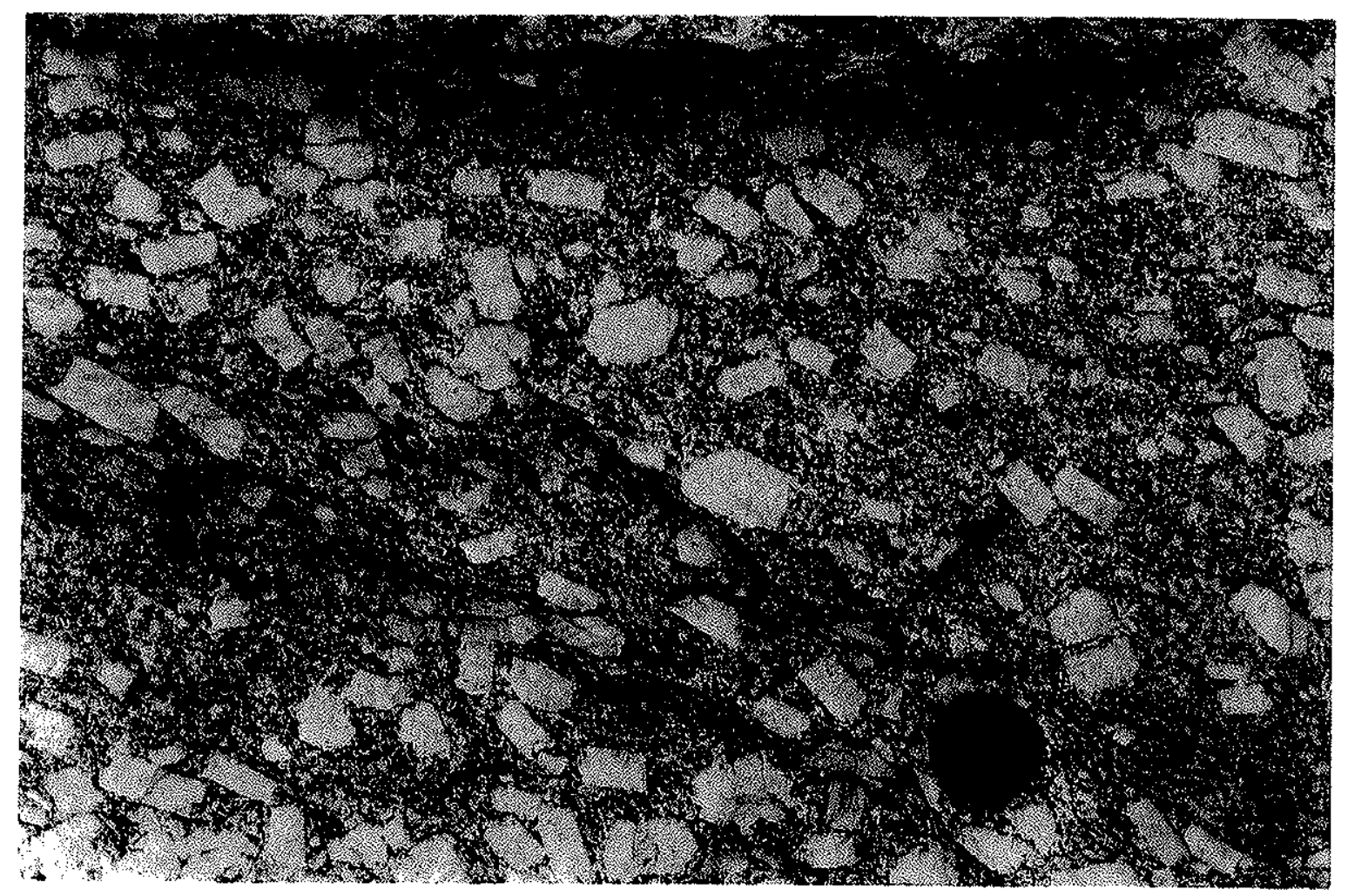

Foto 13) Granito Itaporanga (mesmo afloramento da foto anterior) apresentando foliação magmática dada pele orientação preferencial de minerais máficos e de fenocristais de Kfeldspatos, nos quais pode-se observar estrutura de entelhamento sugerindo movimentação sinistral.

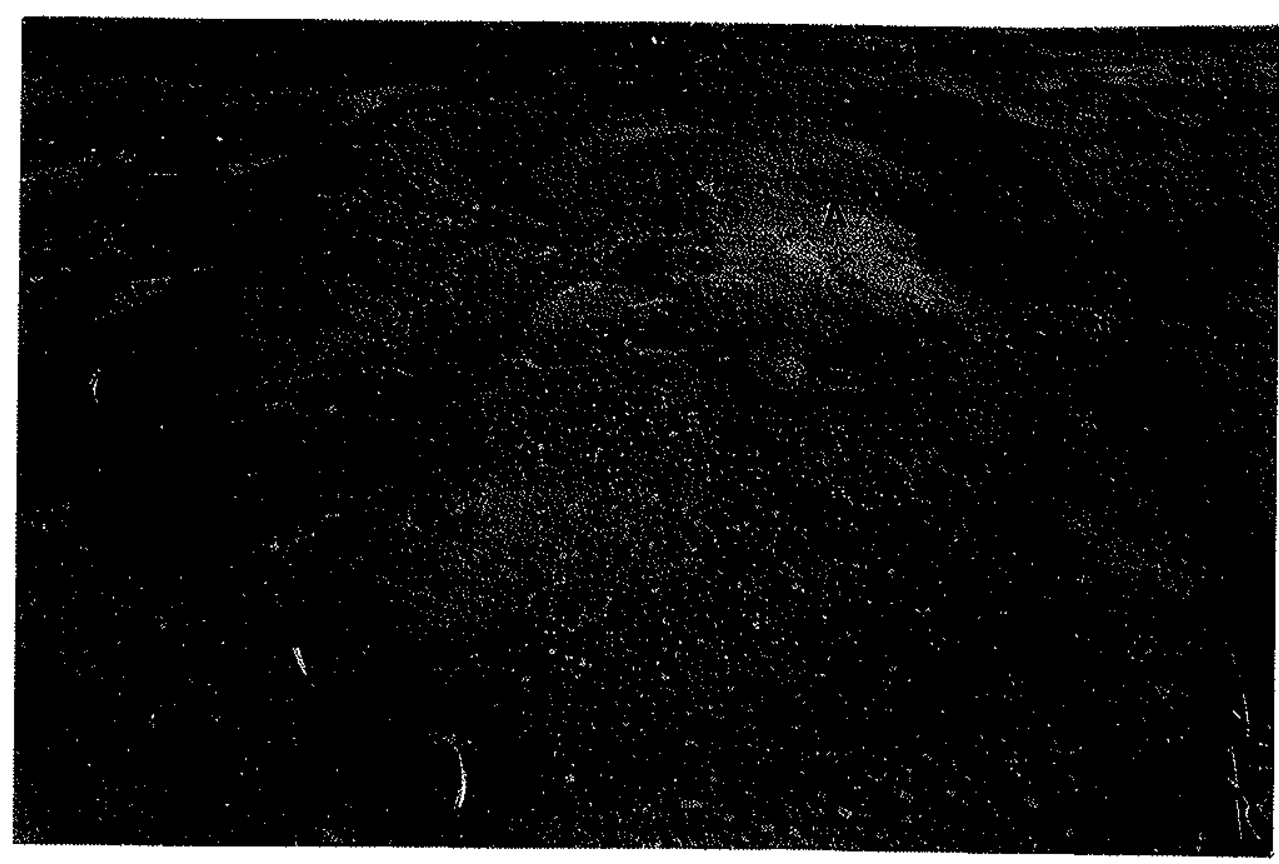

Foto 14) Batólito Tavares: observa-se fluxo magmático convectivo e cumulatos de feldspatos (A). 
O Batólito Itaporanga fornece uma idade isocrônica $\mathrm{Rb}-\mathrm{Sr}$ de $620 \pm 20 \mathrm{Ma}$, com razão inicial de 0.7058 (MCMurry et al, 1987). Idade modelo (Kozuck, inédito) Sm-Nd, T DM de 1644 $\mathrm{Ma}, \mathrm{com} \varepsilon \mathrm{Nd} 600=-9.0$ (Tabelas 3 e 4), indica protólito com longa vida crustal. Datação $\mathrm{Ar}-\mathrm{Ar}$ em minerais (Tabelas 3 e 4) fornecem idades no intervalo 540 (biotita) - $580 \mathrm{Ma}$ (hornblenda) (Dallmeyer et al, 1987), indicando um longo período de resfriamento para as rochas deste batólito.

O Batólito Tavares, intrusivo a sul da Zona de Cisalhamento Serra do Caboclo, tem idade $\mathrm{Rb}-\mathrm{Sr}$ de $650 \mathrm{Ma}$, com $\mathrm{R}_{0}=0.720$ (Brito Neves, inédito) e o granito Princesa Isabel possui idade modelo de $1454 \mathrm{Ma}$, com $\varepsilon_{\mathrm{Nd} 600}=-9.25$ (Tabelas 3 e 4).

Os dados isotópicos Sm-Nd sugerem que os protólitos dos granitos tipo-ltaporanga, localizados a norte da Zona de Cisalhamento Serra do Caboclo têm maior contribuição de crosta mais antiga que os localizados a sudeste. $O$ oposto ocorrendo com os granitos tipoConceição.

\section{III.1.3 Granito Tipo Catingueira/Triunfo}

A sul da área do presente trabalho, na porção central, afloram rochas do batólito sienítico Triunfo e diques associados. Foram estudados por Ferreira (1986) e subdivididos em dois grupos: rochas ultrapotássicas saturadas em sílica (alcali-feldspato sienito) e ultrapotássicas supersaturadas em sílica (quartzo-alcali-feldspato sienito a alcali-feldspato granito com fluorita e cassiterita). O primeiro grupo de rochas forma batólitos e diques alinhados, ocorrentes na bordas SE e SW da Faixa Piancó-Alto-Brígida ("cordão sienitóide"). Rochas do segundo grupo formam batólitos, stocks e diques, com magnetita, aegirina, riebeckita-arfvedsonita e microclina, intrusivos nos complexos metavulcanossedimentares da referida faixa de dobramentos. O caráter ultrapotássico destas rochas peralcalinas foi demonstrado por Ferreira et al (1987), através de estudos da química mineral. Dados de isótopos de oxigênio ( $\delta \mathrm{O}^{18}$ entre +6 e $+8 \%$ SMOW) para o grupo saturado sugerem uma origem a partir da diferenciação de magma basáltico (gerado no manto superior nos estádios iniciais de um rifte Proterozóico). Nas rochas do grupo supersaturado os dados de oxigênio ( $\delta$ $\mathrm{O}^{18}$ entre +6 e $+10 \%$ SMOW) sugerem alteração posterior por água meteórica a qual deve ter interagido com feldspato (Ferreira, 1986). Os plutons saturados receberam maior contribuiçäo crustal em sua evolução e constituem uma atividade peralcalina mais recente.

Medeiros (1995) considera as rochas sienitóides peralcalinas tipo-Triunfo como granitos 
do tipo-I provenientes de uma fonte mantélica eriquecida em LILE.

O sienito de Triunfo, na localidade de Baixa Verde tem idade K-Ar em feldspato de 570 $\mathrm{Ma}$ (Almeida et al, 1968), confirmada por Ferreira et al. (1997) pelo método Rb-Sr. Dados SmNd neste sienito, em diques associados e no granito Catingueira fornecem $T_{D M}$ entre 1.8 e 2.4 Ga com $\varepsilon N d 600$ entre -12.1 e -16.4 (Tabelas 3 e 4).

\section{III.1.4 Gabro Tipo Taperoá}

Na porção meridional da área do presente trabalho, na localidade de Alto Vermelho, aflora um gabro com cerca de $1,5 \mathrm{Km}$ de espessura, de granulometria grossa, constituído por anfibólio, piroxênio, plagioclásio e quartzo. Apresenta nas bordas uma fraca foliação, dada pela orientação de feldspatos e anfibólios. É intrusivo nas rochas do Complexo Cachoeirinha e limitado por falhas rúpteis subverticais (Perfil F.F', anexo 4) e desenvolve uma auréola de contato, com cerca de 4 metros de largura.

Dados Sm-Nd fornecem $T_{D M}$ de $1.5 \mathrm{Ga}$ (possivelmente sem significado em face a elevadas razões ${ }^{147} \mathrm{Sm}-{ }^{144} \mathrm{Nd} \gg 0.1$, nestas rochas) com $\varepsilon_{\mathrm{Nd} d 00}$ de -2.5 e $\varepsilon_{\mathrm{Nd1000}}$ de 0.81 (Tabela 3). Estes dados, sugerem o envolvimento de crosta tipo-Cariris Velhos, ou mesmo material juvenil Brasiliano no protólito desta rocha. Intrusão gabróide Brasiliana (idade U-Pb de $600 \mathrm{Ma}$ ) foi identificada por Kozuch et al (1997) em Jabitacá, cortando rochas da Faixa Pajeú-Paraiba (Tabela 4).

\section{IIII.1.5 Granito Tipo-S}

Na localidade da Serra Comprida, a cerca de $20 \mathrm{Km}$ a norte da cidade de Serra Talhada, ocorre um corpo granítico leucocrático, equigranular de granulação média a fina, constituido por feldspatos, quartzo, biotita, anfibólios, granada e minerais opacos. Apresenta um discreto bandamento magmático associado a orientação preferencial de minerais máficos e, contém vários xenólitos de anfibolito bandado e de anfibólio xisto. 


\section{IIII.2 Ortognaisses Cariris Velhos}

Ocorrem bordejando o Alto do Teixeira-Terra Nova, e na área estudada no presente trabalho, afloram a norte de Serra Talhada e a noroeste de Tavares.(Fig. 7).

São granito-gnaisses cinza a cinza-rosado, de granulação média a grossa. No geral, mostram textura protomilonítica porfiroclástica (Foto 16). Estruturas migmatíticas ocorrem localmente. Possuem composição granítica, com quartzo, plagioclásio (porfiroclástos com cerca de $1 \mathrm{~cm}$ de comprimento, em média, K-feldspatos, biotita, muscovita e granada (locais) e minerais opacos.

Brito Neves et al (1995 e inéditos) têm sistematicamente datado estes ortognaisses, que segundo os referidos autores prolongam-se por cerca de $700 \mathrm{~km}$, desde Afeição, no Piauí, até Soledade, na Paraíba. As idades U-Pb e idades convencionais e isocrônicas Rb-Sr obtidas variam entre 920 e 1040 (Tabela 5). Dados Sm-Nd para estas rochas fornecem T $T_{\text {DM }}$ entre 1.4 e $1.9 \mathrm{Ga}$, com $\varepsilon_{\mathrm{Nd} 600}$ variando de -2.5 a -5.2 e $\varepsilon_{\mathrm{Nd} 1000}$ de -1.1 a 1.7 , sugerindo retrabalhamento de crosta mais antiga.

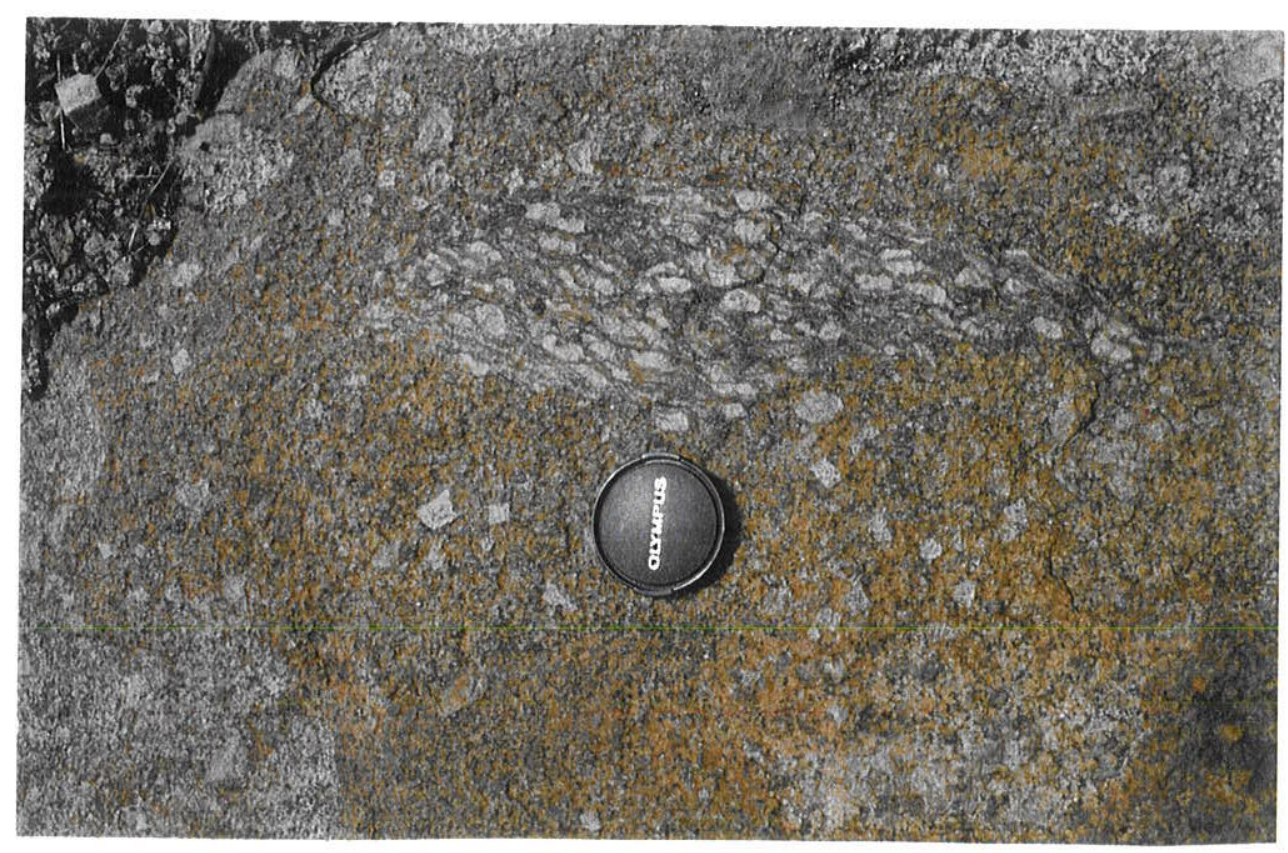

Foto 15) Xenólito de ortognaisse Cariris Velhos, com textura milonítica, no granito tipo Itaporanga. Localização a norte da cidade de Tavares. 


\section{METAMORFISMO}

O metamorfismo, na área do presente trabalho, atingiu as condições máximas de temperatura $(T)$ e pressão $(P)$ durante o desenvolvimento da foliação regional principal $S 2$, associada a segunda fase de deformação (F2). A foliação S2 é uma foliação de baixo ângulo, correlacionáveis através das diversas amêndoas/domínios definidos no Capitulo 2 , descrevendo um transporte para sudeste. As exceções encontram-se na amêndoa onde aflora a Sequência Serra do Otho D'Água, mais jovem, e na Amêndoa Macacos-Piaus (Complexo Riacho Gravatá) onde a foliação principal está controlada pela transpressão do sistema de cisalhamento transcorrente superimposto à $\mathrm{S} 2$.

Na Amêndoa Piancó (a norte), área de ocorrência do Complexo Cachoeirinha, e na porção sudoeste da Amêndoa Serra da Pinheira (a sul), onde afloram rochas do Complexo Riacho Gravatá, a presença de sillimanita e/ou ocorrência localizada de anatexia, denotam gradiente térmico mais elevado que no resto da área estudada.

Com o intuito de estudar as condições metamónficas ocorridas nas referidas amêndoas durante o metamorfismo principal, foram selecionadas amostras cujas paragêneses são utilizadas nos diversos termômetros e/ou barômetros descritos na literatura e discutidos na seção IV. 3 deste capítulo.

\section{IV.1 MICROESTRUTURAS E TEXTURAS}

As rochas metassedimentares e metavulcânicas ácidas a intermediárias do Complexo Riacho Gravatá em suas três amêndoas (Serra da Pinheira, Macacos-Piaus e Serra do Mocambo) possuem, como feição principal, uma foliação tectônica proeminente, conferida pela orientação preferencial de micas (muscovita, biotita, e clorita), feldspatos, turmalina, nibbons quartzo e de minerais opacos tabulares. Nas rochas metabásicas a foliação principal é dada pela orientação preferencial de anfibólios, biotitas, cloritas, titanitas e de minerais opacos.

Microestruturas tais como: arcos poligonais, indicando a recristalização de charneiras pretéritas; inclusões orientadas retas ou onduladas, definindo uma foliação interna ( $\mathrm{Si}$ ) nas granadas, sem continuidade com a foliação externa (Se) (Fotos 16 e 17) e a presença de 
charneiras reliqueares em áreas mais preservadas da deformação (Foto 17), são indicativas do caráter \$2 da foliação principal. Isto é, uma foliação gerada pelo incremento da deformação e da recristalisação metamórfica sobre um estádio precoce $\mathrm{S} 1$. A foliação $\mathrm{S} 2$ pode estar associada a um processo de cisalhamento dúctil, desenvolvendo estruturas sigmóides do tipo S-C (Lister \& Snoke, 1984). Venulaçōes de quartzo, por vezes sigmoidais e paralelas a direção-S, devem ter se formado durante o auge do metamorfismo por processo de dissolução/recristalização (Fotos 18a e 18b).

A foliação S2 encontra-se dobrada e crenulada por uma deformação posterior desenvolvida sob condições mais tênues de temperatura e de pressão (Fotos 18a e 18b). Extinção ondulante em muscovitas e biotitas, deformação das fibras desenvolvidas em zonas de sombra de pressão em granadas, deformação/recristalização de quartzo e, mais raramente de feldspatos e anfibólios, boudinage de anfibólios e turmalinas e, por fim, transposiçăo da foliação S2, são as estruturas superimpostas mais frequentes. Essa nova foliação S3 é, via de regra, milonítica (Foto 19) e pode estar acompanhada da recristalização de biotita e/ou muscovita, oblíquas a perpendiculares a foliação $\$ 2$, orientadas no plano axial de dobras e crenulações de terceira fase D3. Estas micas podem também estarem deformadas ulteriormente em kink bands de caráter mais rúptil e de expressão local (Foto 20). Os processos de alteração deutérica observados nas rochas do Complexo Riacho Gravatá são: substituição de granada e, mais raramente, anfibólios por biotita, cloritização das biotitas, serissitização de feldspatos e oxidação de minerais opacos.

$\mathrm{Na}$ Amêndoa Macacos-Piaus, a terceira fase de deformação é mais intensa e a transposição da foliação $S 2$ pela foliação $S 3$, mais generalizada. Neste domínio não foi possivel resgatar o sentido de transporte na foliação $S 2$, entretanto o sentido de transporte na foliação S3 é para nordeste, associado a intensa transpressão entre zonas de cisalhamento transcorrentes dextrais.

O Complexo Cachoeirinha apresenta como estrutura mais marcante uma foliação tectônica bem desenvolvida dada pela orientação preferencial de minerais planares e tabulares, relacionada a uma segunda fase de deformação, que transpõe, generalizadamente, uma foliação $S 1$ pretérita. Isto fica evidente pela existência de chaneiras reliqueares de microdobras e de crenulações aprisionadas dentro da foliação principal, pelas inclusões orientadas (Foto 21 e 22) em granadas (Sequência Santana dos Garrotes e Sequência Piancó), estaurolitas e cordieritas (Sequência Piancó), e pela existência de arcos poligonais em micas, indicando o dobramento de uma foliação pretérita, posteriormente recristalizada como processo final de recuperação dos gräos deformados (Foto 22). 
O crescimento e/ou recristalização de associações minerais metamórficos evidencia que o metamorfismo atingiu seu auge durante a segunda fase de deformação também nas rochas do Complexo Cachoeirinha. Deformação posterior, relacionada a terceira fase (F3), crenula a foliação $\mathrm{S} 2$, desenvolvendo dobras que, localmente, degeneram em empurrões tardios de pequena movimentação com sentido para sudeste, e clivagem de crenulação, paralela a qual, ocorrem localmente biotitas e muscovitas orientadas, associadas a um metamorfismo retrógrado. Deformação localizada posterior a F3 também é descrita neste complexo, através de kink bands nas micas e crenulações abertas a suaves que deformam a foliação S3.

Nos Xistos Sertânia, pouco estudado no presente trabalho, também foram identificadas as mesmas estruturas e texturas descritas acima, indicando que o auge do metamorfismo ocorreu durante a fase F2.

As associações minerais descritas no Complexo Riacho Gravatá, no Complexo Cachoeirinha e nos Xistos Sertânia, nas diferentes amêndoas ou domínios definidos, estão sumarizadas na Tabela 6. Dentre estas associações, algumas paragêneses minerais desenvolvidas durante o pico do metamorfismo, foram estudadas visando estabelecer as condições de temperatura e pressão em que foram formadas.

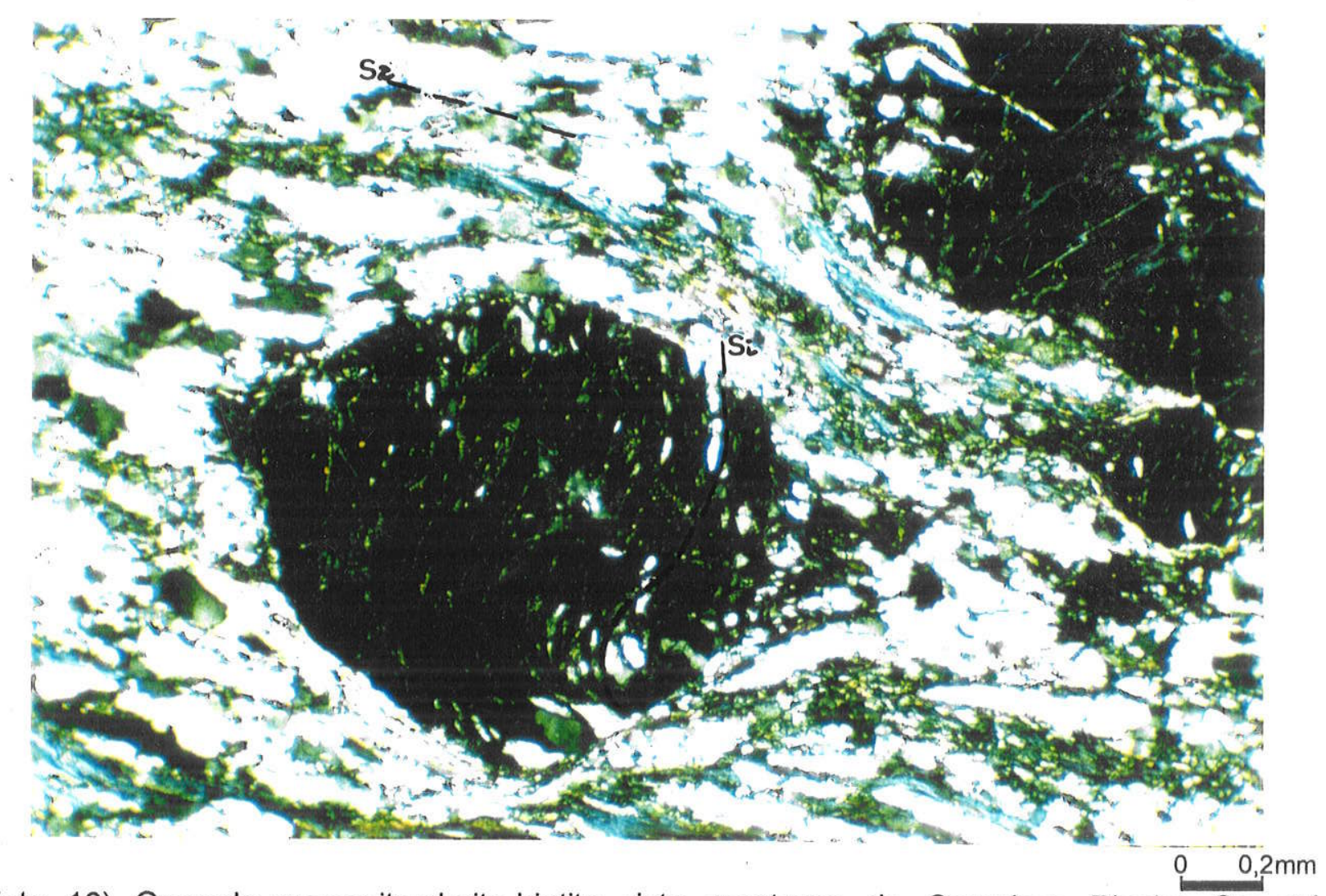

Foto 16) Granada-muscovita-clorita-biotita xisto quartzoso do Complexo Riacho Gravatá (Amêndoa Serra do Mocambo). Observa-se granada com Si ondulada, possivelmente um representando estágio precoce da crenulação D2, sem continuidade com S2 externa. (nicóis //) 


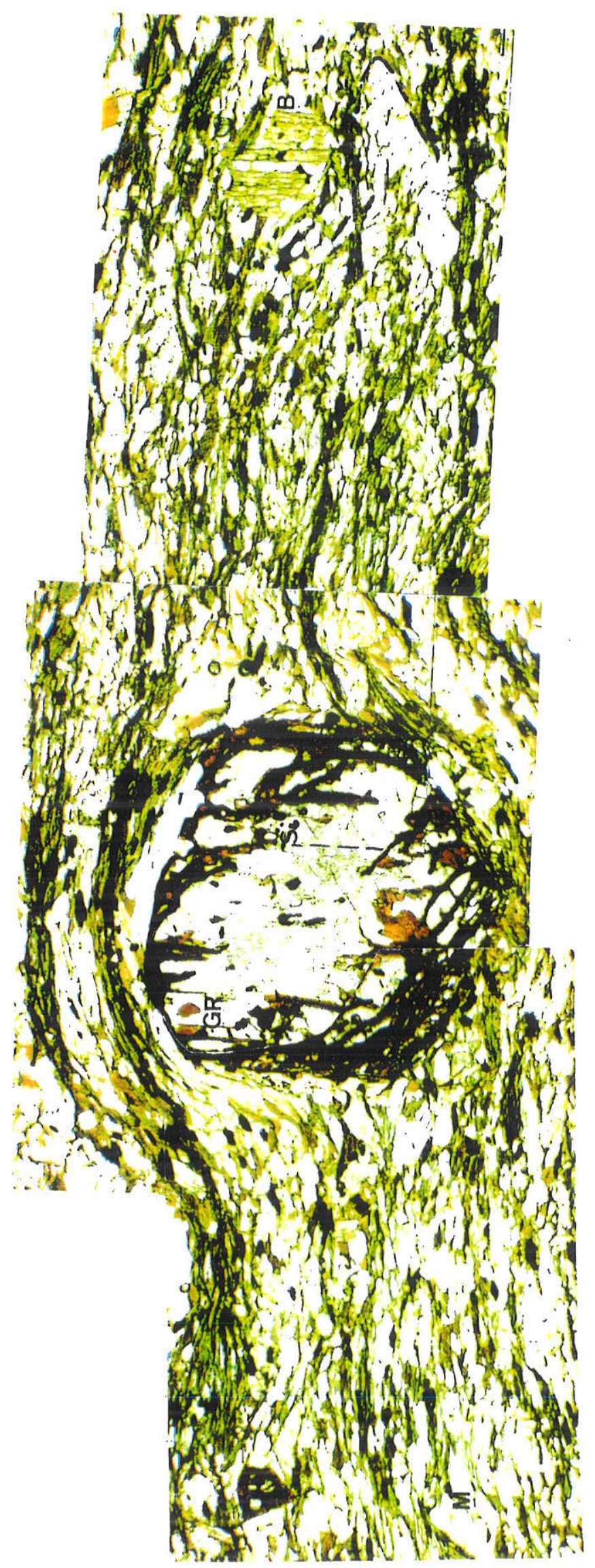

Foto 17) Granada-biotita-muscovita xisto do Complexo Riacho Gravatá, Amêndoa Serra da Pinheira.Observa-se granada ( $\mathrm{Gr}$ ) com foliação interna (Si) disrupta da foliação externa (S2), definida como clivagem de crenulação transposta; biotita (B) e muscovita (M) pós-S2. (nicóis //) 

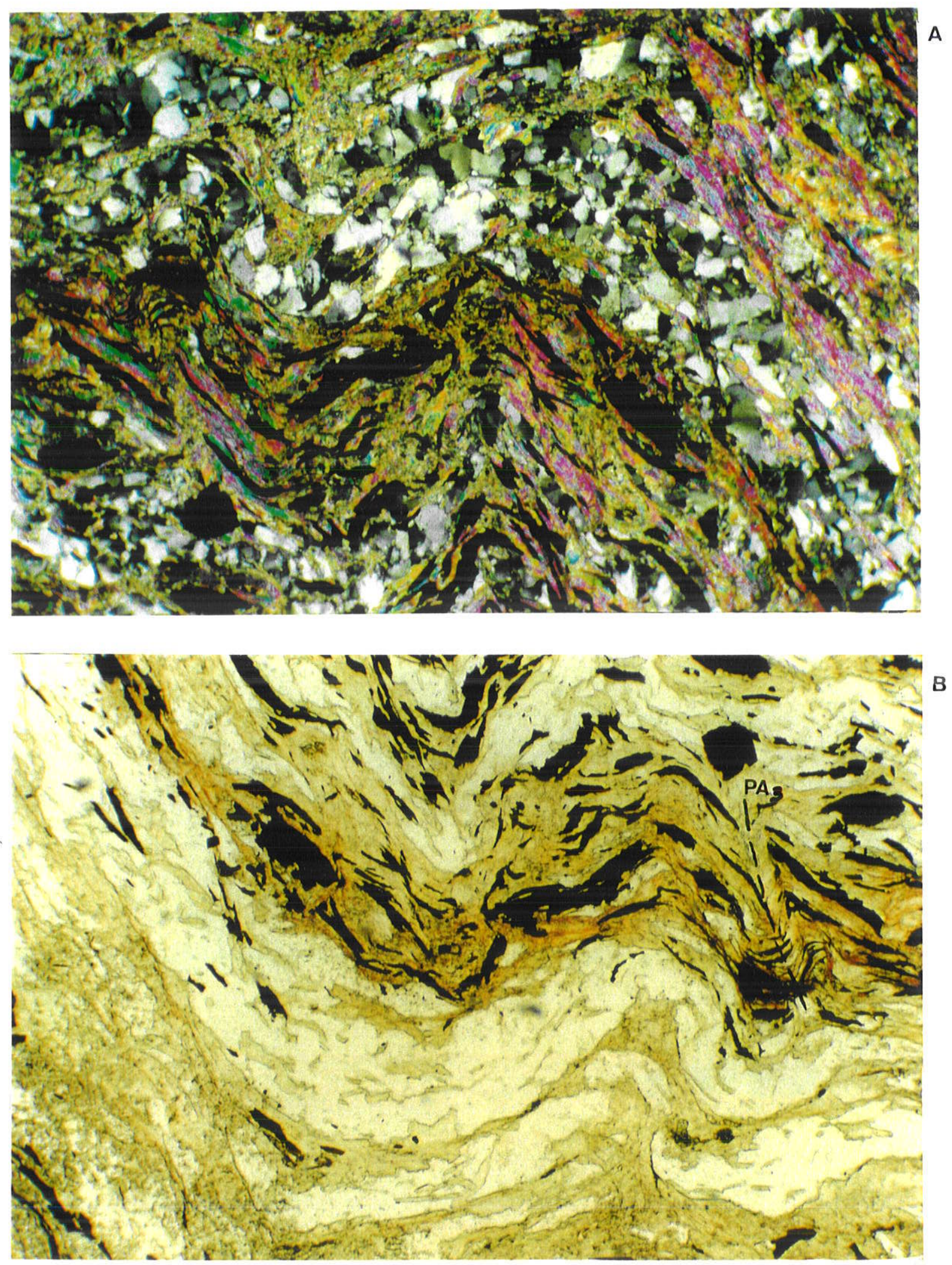

$0,2 \mathrm{~mm}$

Foto 18) Muscovita-biotita xisto quartzoso do Complexo Riacho Gravatá (Amêndoa Serra da Pinheira), com foliação S2 milonítica, com venulas de quartzo paralelas ao plano $\mathrm{S}$, crenuladas por D3. ( A - nicóis X; B - nicóis //) 


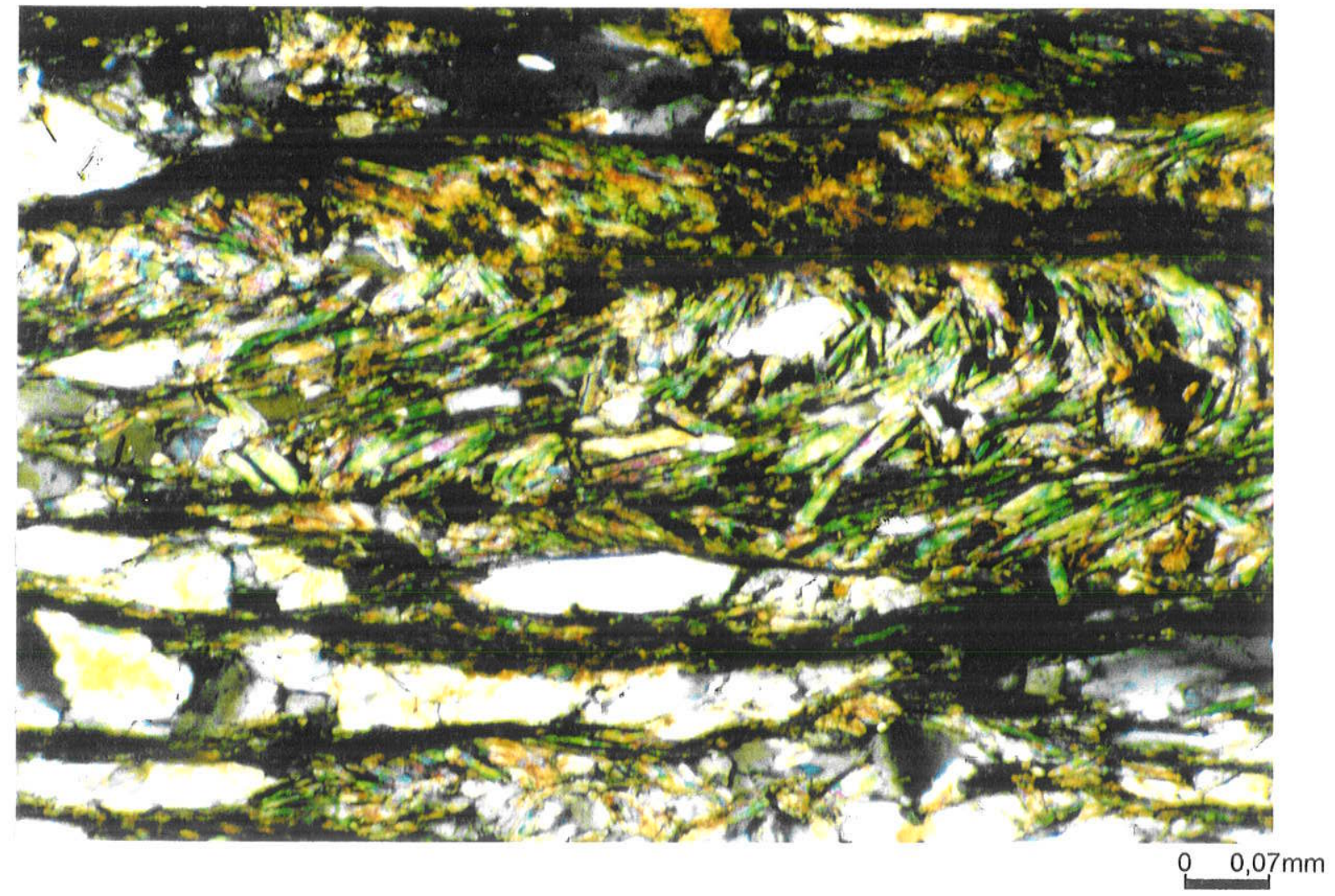

Foto 19) Muscovita-biotita xisto do Complexo Riacho Gravatá (Amêndoa Serra da Pinheira) mostrando foliação S2 transposta por S3 milonítica. (nicóis X)

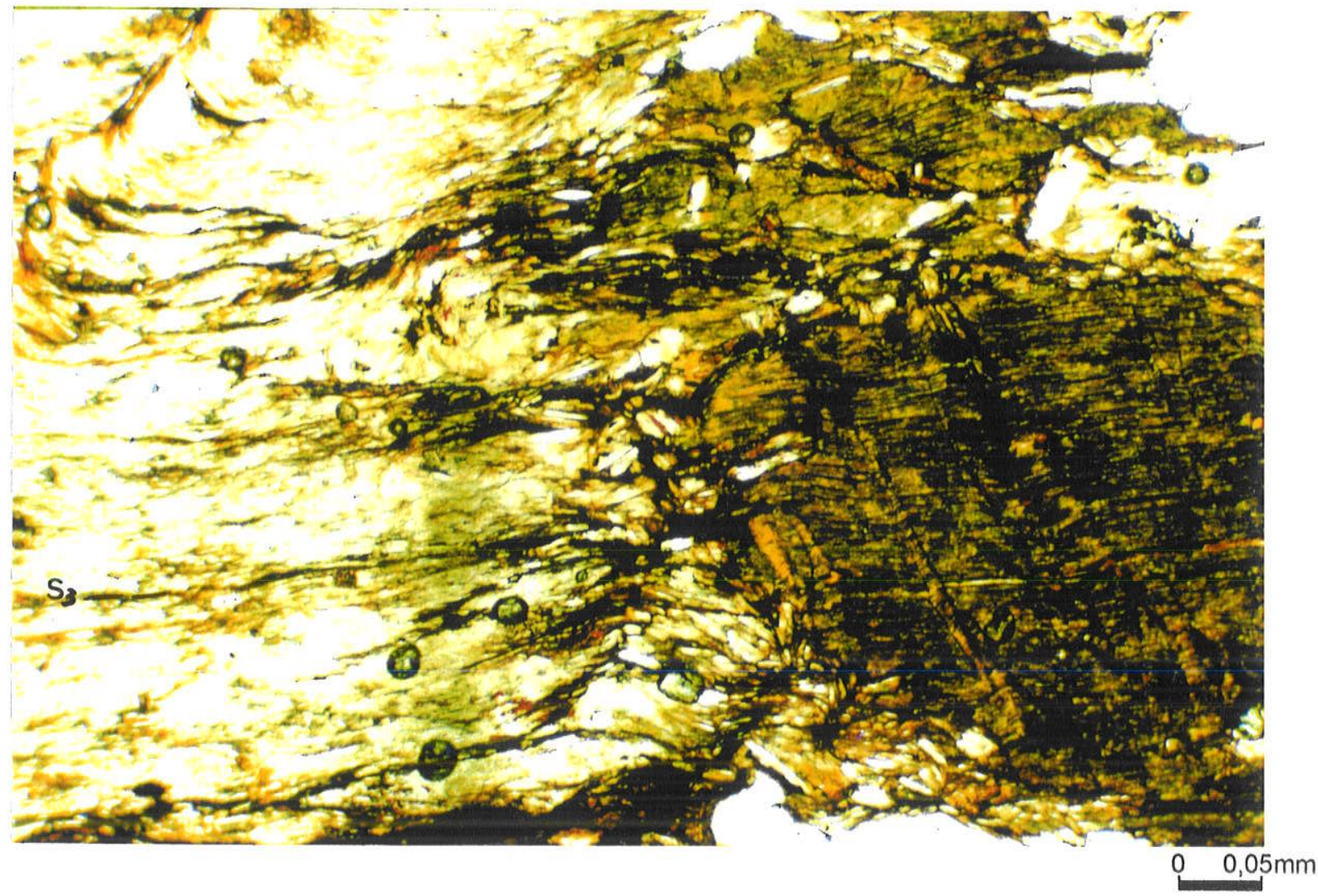

Foto 20) Granada-muscovita-biotia gnaisse do Complexo Riacho Gravatá (Amêndoa MacacosPiaus). Observa-se porfiroclásto tardio de biotita apresentando kinks bands. (nicóis //) 


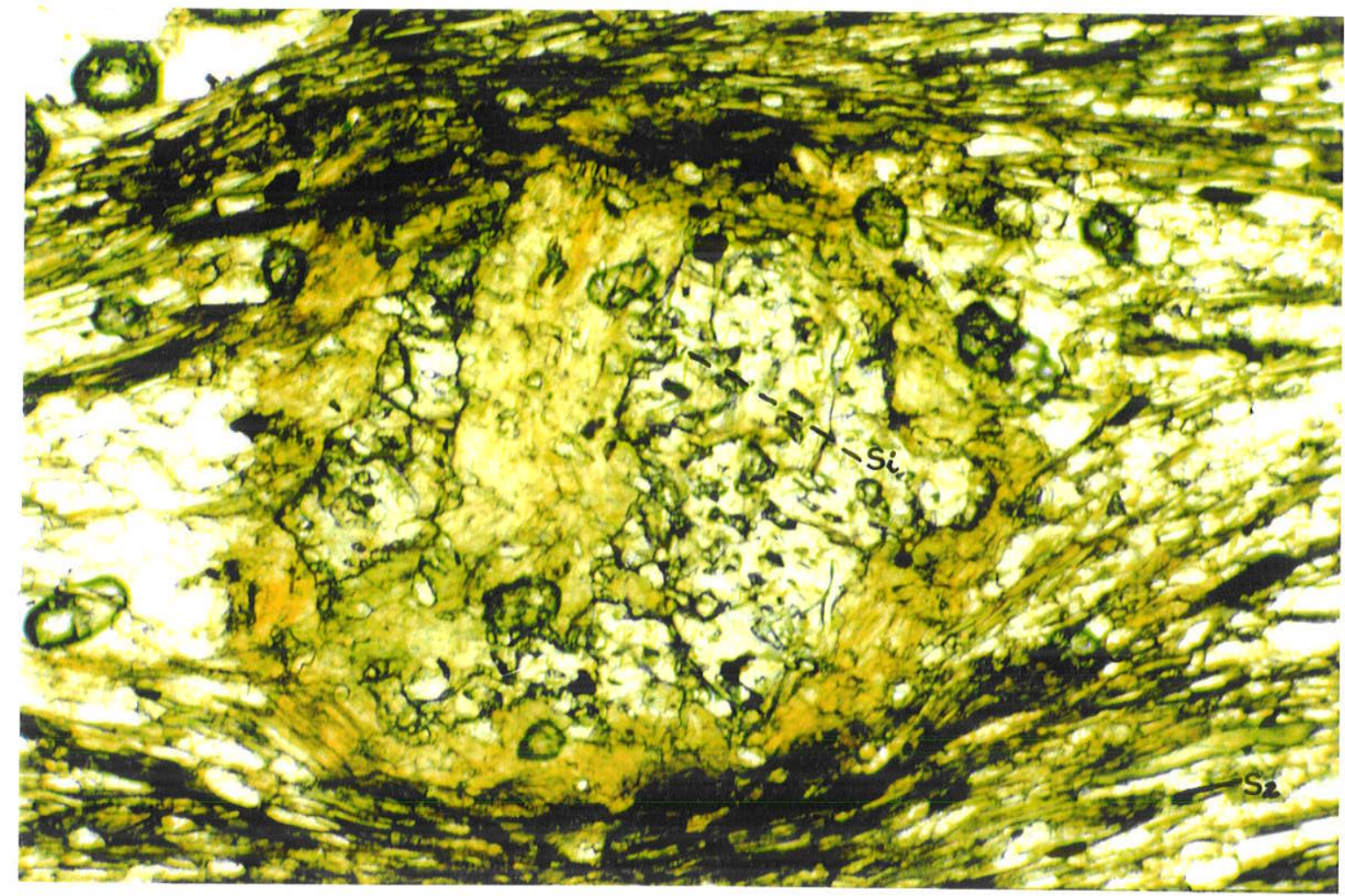

$0,1 \mathrm{~mm}$

Foto 21) Muscovita-biotita xisto fino cinza do Complexo Cachoeirinha (Sequência Santana dos Garrotes), onde pode-se observar granada com foliação Si e foliação externa S2 desviando-se ao redor desta, e desenvolvendo sombra de pressão, local. (nicóis //)

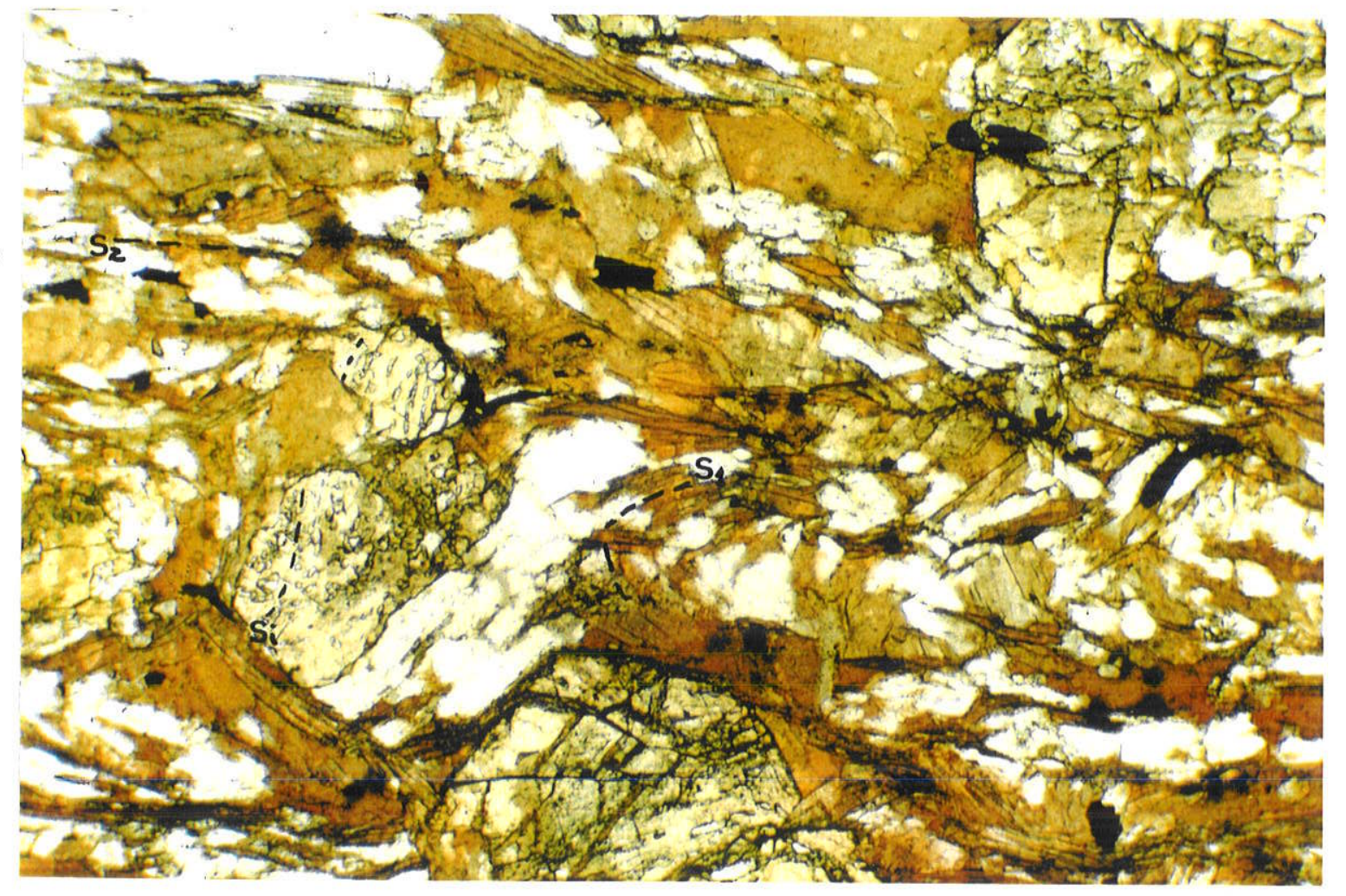

$0 \quad 0,2 \mathrm{~mm}$

Foto 22) Granada-estaurolita-muscovita-biotita xisto do Complexo Cachoeirinha (Sequência Piancó). Observa-se estaurolita com foliação interna Si, interpretada como foliação S1, crenulada abertamente por S2; a foliação externa S2, representada por uma clivagem de crenulação, e charneiras relictas D2 locais. (nicóis /I) 


\section{IV.2 QUIMICA MINERAL}

Análises químicas pontuais foram realizadas no Laboratório de Microssonda e Microscopia Eletrônicas do Departamento de Mineralogia e Petrologia - IG/USP, através de uma microsonda eletrônica do tipo JXA-8600 Superprobe (JEOL) com automação TRACONNORAN, equipada com sistema detetor WDS, e operada sob condições de 20,05 a 20,2 nA de corrente e 15,0 KV de potencial de aceleraçăo.

Os minerais analisados foram aqueles cujas paragênese apresentam importância sob o ponto de vista do cálculo das temperaturas e pressōes a que a rocha esteve submetida, em função dos diversos barômetros e termômetros existentes na literatura. A composição química dos minerais coexistentes em paragênese ou não, visa estabelecer comparações entre as características químicas das fases analisadas (biotita, clorita, muscovita, granada, feldspato e anfibólios) nas diversas unidades mapeadas no presente trabalho, além de sua utilização na interpretação das condições metamórficas.

O cálculo das fórmulas estruturais dos minerais analisados, seguem os parâmetros utilizados e referidos pelos diferentes autores dos termômetros e barômetros aplicados. Tais cálculos foram executados através do Programa "Planilha Excel", que também foi utilizado para o cálculo dos geotermômetros e geobarômetros aplicados.

Gráficos com classificação de anfibólios e aqueles que correlacionam composição e condições de $T$ ou $P$ foram confeccionados na Planilha Excel, enquanto os gráficos de classificação dos demais minerais analisados (biotitas, muscovitas, feldspatos e granadas) foram construídos no Programa Minpet 2.0, a partir dos cálculos das fórmulas estruturais obtidos na Planilha Excel.

\section{IV.2.1 Química Mineral dos Metassedimentos}

Nos metassedimentos dos complexos Riacho Gravatá e Cachoeirinha e nos Xistos Sertânia, foram feitas análises químicas pontuais em cloritas, biotitas, feldspatos, granadas e muscovitas, para fins de caracterização química e quantificação do metamorfismo. Os resultados obtidos são analisados a seguir. 


\section{A) Cloritas:}

As cloritas nos metassedimentos da área do presente trabalho, são observadas em lâmina delgada, via de regra substituindo granadas e biotitas, possivelmente relacionadas a processos de alteração deutérica.

$\mathrm{Na}$ Tabela 7 são apresentadas as análises químicas de cloritas recalculadas para 14oxigênios com todo ferro considerado como $\mathrm{Fe}^{2+}$ (seguindo as especificações de Deer et al, 1978).

As cloritas analisadas nos dois complexos supracitados caem nos campos de classificação de cloritas frescas (Deer et al, 1975) da ripidolita, picnoclorita e diabanita (Fig. 8)

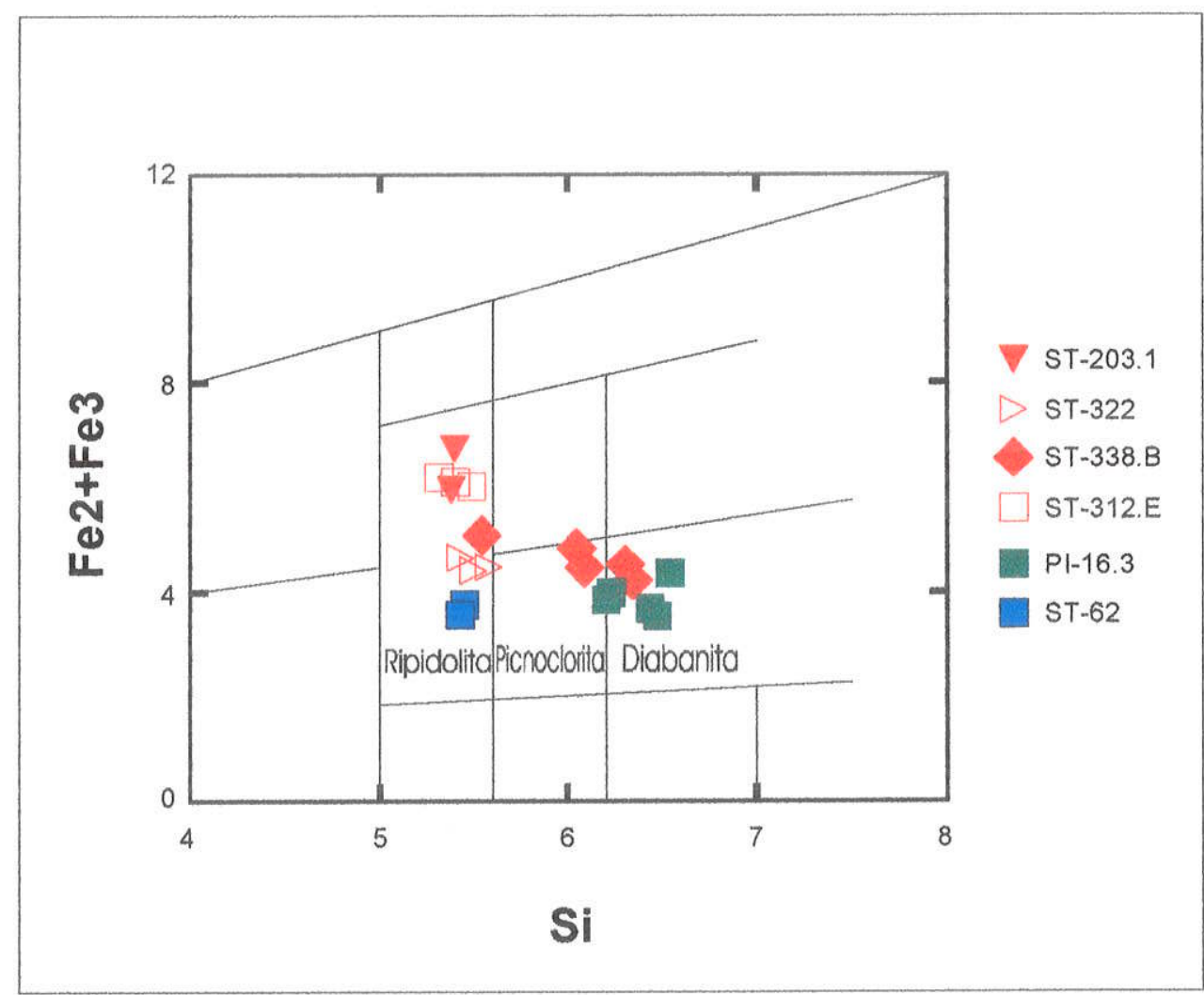

Fig. 8) Classificação das cloritas analisadas no presente trabalho segundo a nomenclatura de Deer et al (1978). Símbolos: vermelho - Complexo Riacho Gravatá; verde - Sequência Piancó (CC); azul - Sequência Santana dos Garrotes (CC). 


\section{B) Biotitas:}

As biotitas analisadas nos metassedimentos dos complexos Riacho Gravatá e Cachoeirinha, neste trabalho, tiveram sua fórmula estrutural calculada para 11-oxigênios com todo ferro considerado como $\mathrm{Fe}^{2+}$ (Tabela 8 )

Ocorrem, normalmente, orientadas segundo a foliação principal. Algumas amostras apresentam uma outra fase de (re)cristalização de biotitas, constituída por porfiroblástos orientados obliqua ou perpendicularmente à foliaçăo principal, possivelmente relacionadas a retrometamorfismo. Além destas fases, biotitas inclusas em granadas foram analisadas.

Observando-se os gráficos $\mathrm{Fe} / \mathrm{Fe}+\mathrm{Mg} \times \mathrm{Al} \mathrm{l}^{\mathrm{V}}$ e $\mathrm{Fe} / \mathrm{Fe}+\mathrm{Mg} \times \mathrm{Al}^{\mathrm{Vl}}$ (Fig. 9A e 9B) nota-se que nas rochas metassedimentares do Complexo Riacho Gravatá as razões $\mathrm{Fe} / \mathrm{Fe}+\mathrm{Mg}$ atingem valores mais altos do que aquelas do Complexo Cachoeirinha, o que pode indicar fontes distintas para estes dois complexos. Além disto, observa-se uma tendência a homogeneização química entre as biotitas orientadas paralelas a foliação principal e aquelas obliquas ou perpendiculares a mesma, indicando que houve equilibrio constante durante 0 metamorfismo que as gerou. Entretanto, nota-se uma discreta diferença entre as biotitas que ocorrem como inclusões em granadas e as anteriormente descritas, principalmente no que se refere aos teores de $\mathrm{Al}^{\mathrm{V}}{ }^{\text {}}$, mais elevados na amostra $\mathrm{Pl}-16.3$, localizada na Sequência Piancó, e mais baixo na amostra (ST-488), pertencente aos Xistos Sertânia. Guidotti et al (1984) relaciona o aumento nos teores de $\mathrm{Al}^{\mathrm{VI}}$ e de $\mathrm{Ti}^{\mathrm{VI}}$ ao aumento na temperatura de cristalizaçăo de micas em rochas mertamórficas.

No gráfico $\mathrm{Ti}^{\mathrm{V}} \times \mathrm{Al}^{\mathrm{V}}$ (Fig. $9 \mathrm{C}$ ) relação acima citada fica ainda mais evidente: todas as amostras nas quais biotita ocorre associada a sillimanita (PI-16.3 e ST-488), esta encontra-se no campo onde os teores de $\mathrm{Al}^{\mathrm{VI}}$ e $\mathrm{Ti}^{\mathrm{VI}}$ são mais elevados. Isto indica, comparando as biotitas inclusas em granadas com aquelas orientadas segundo a foliação principal, que na mostra PI16.3 temperaturas mais elevadas ocorreram no início do metamorfismo, enquanto na amostra ST-488 temperaturas mais elevadas săo tardias. 

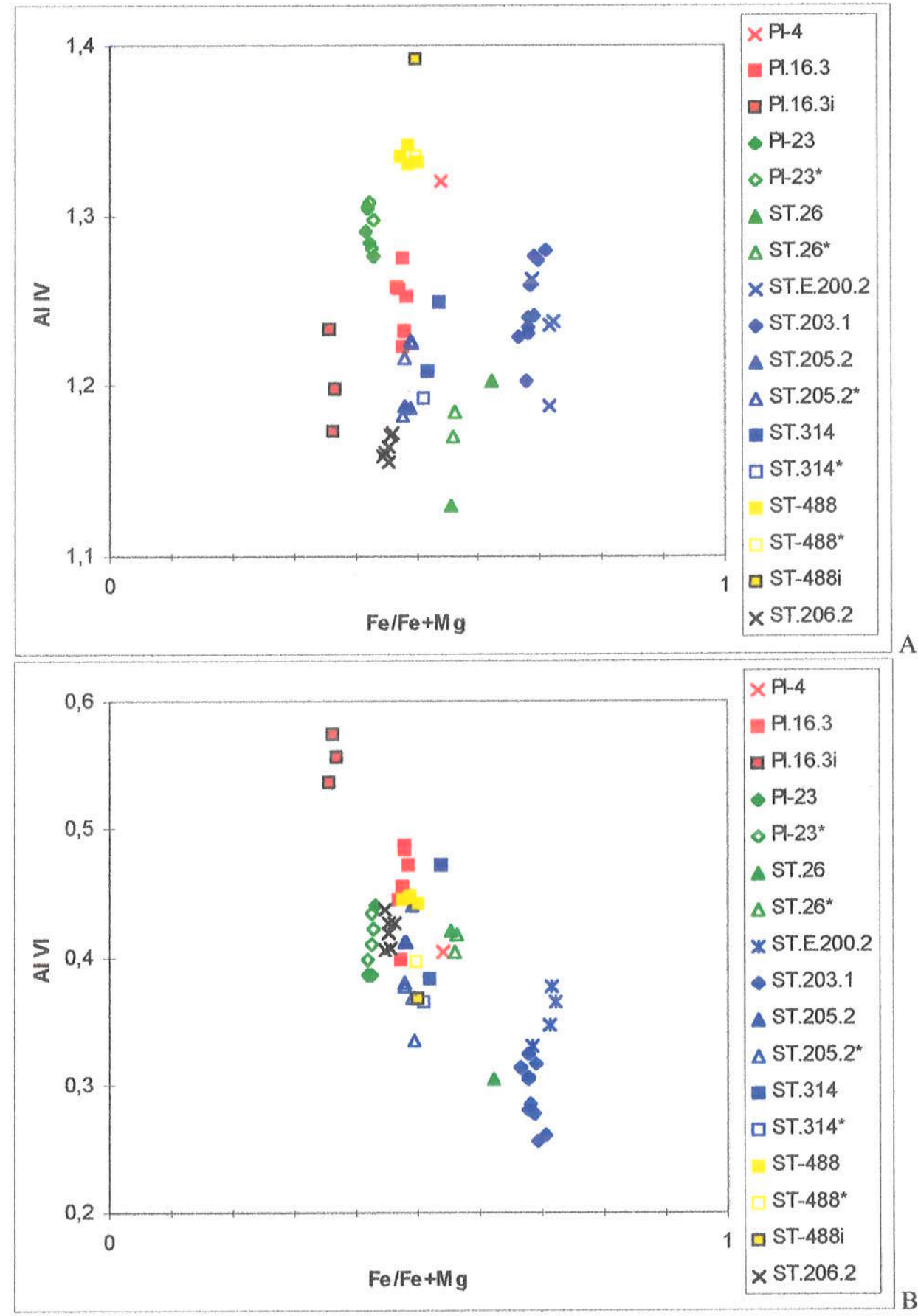

Fig. 9) Representação gráfica das biotitas analisadas no presente trabalho. Simbologia: vermelho - metassedimentos da Sequência Piancó (CC), verde - metassedimentos da Sequência Santana dos Garrotes (CC), azul - metassedimentos da Amêndoa Macacos-Piaus (CRG), amarelo - xistos do Sertânia, preto - metabásicas da Amêndoa Macacos-Piaus (CRG).; preenchido - paralelas a foliação principal; vazios - minerais orientados oblíqua e/ou perpendicularmente a foliação principal, com borda preta - inclusas em granadas. 


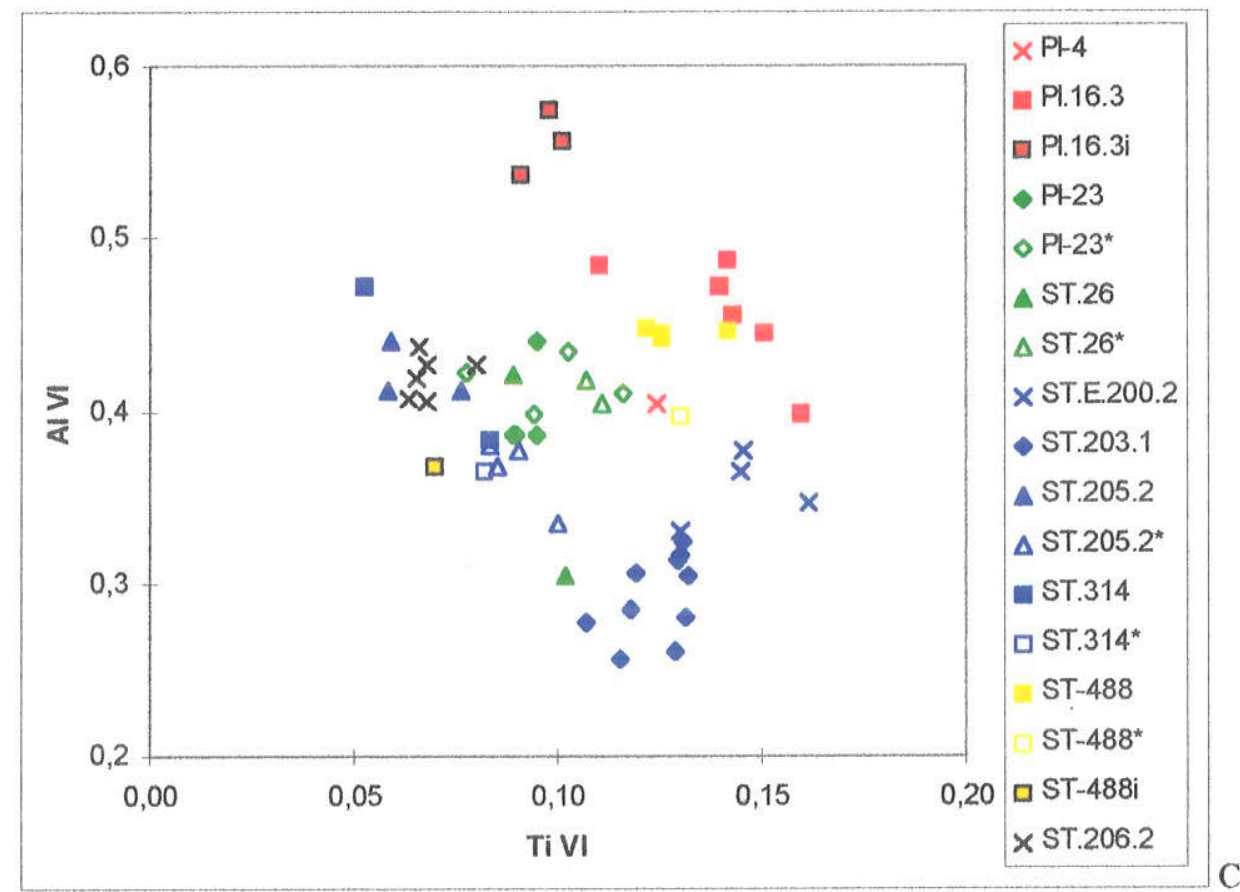

Fig. 9) Continuação.

\section{C) Feldspatos:}

Os dados de química mineral dos feldspatos dos metassedimentos analisados no presente trabalho estão expressos na Tabela 9 e representados no diagrama albita-anortitaortoclásio (Fig. 10).

No Complexo Cachoeirinha, os fedspatos analisados na Sequência Piancó são do tipo oligoclásio-andesina com composição variando de $\mathrm{Ab}_{54-72}-\mathrm{An}_{28-45}-\mathrm{Or}_{0-1}(\mathrm{Pl}-4), \mathrm{Ab}_{75-79}-\mathrm{An}_{21-26}-\mathrm{Or}_{0-}$ 1 (PI-16.3), enquanto aqueles analisados na Sequência Santana dos Garrotes são oligoclásios e apresentam composição $\mathrm{Ab}_{82-84}-\mathrm{An}_{15-18}{ }^{-} \mathrm{Or}_{0-1}$ (PI-23).

No Complexo Riacho Gravatá, Amêndoa Macacos-Piaus, os feldspatos analisados apresentam composição entre albita $\left(A b_{96-98}-A n_{2-4}\right.$, amostra ST-200.2) e oligoclásio $\left(A b_{74-87^{-}}\right.$ $A n_{13-26}-\mathrm{Or}_{0-1}$, amostra ST-203.1). Na Amêndoa Serra da Pinheira, a cerca de $3 \mathrm{Km}$ ao norte de Santa Rita (porção sudeste), os feldspatos são do tipo oligoclásio ( $\left.A b_{81-82}-A n_{15-19}-\mathrm{Or}_{0-3}\right)$.

Nos xistos Sertânia (amostra ST-488) foram analisados feldspatos inclusos na borda da granada, que apresentaram composição $A b_{64-70}-A n_{30-35}-O r_{0-1}$ e feldspatos orientados segundo a foliação principal, que mostram um ligeiro empobrecimento de Ca no centro $\left(\mathrm{Ab}_{69-73-}-\mathrm{An}_{26-29}-\mathrm{Or}_{1}\right.$ 2) em relação as bordas $\left(A b_{71-75}-A n_{24-28}-O r_{0-1}\right)$. 
Dentre os feldspatos analisados nos metassedimentos observa-se que aqueles localizados na Sequência Piancó e o dos Xistos Sertânia apresentam-se mais ricos no componente anortita que os demais. Isto é coerente com as condições de temperatura observadas através das associações minerais, uma vez que já que sillimanita é o alumínio silicato presente nestas rochas. Estas observações são coerentes com aquelas obtidas na interpretação do gráfico $\mathrm{Ti}^{\mathrm{Vl}} \times \mathrm{Al}^{\mathrm{VI}}$ para as biotitas (Fig. $8 \mathrm{C}$ ), que também sugerem temperaturas mais elevadas para estas rochas.

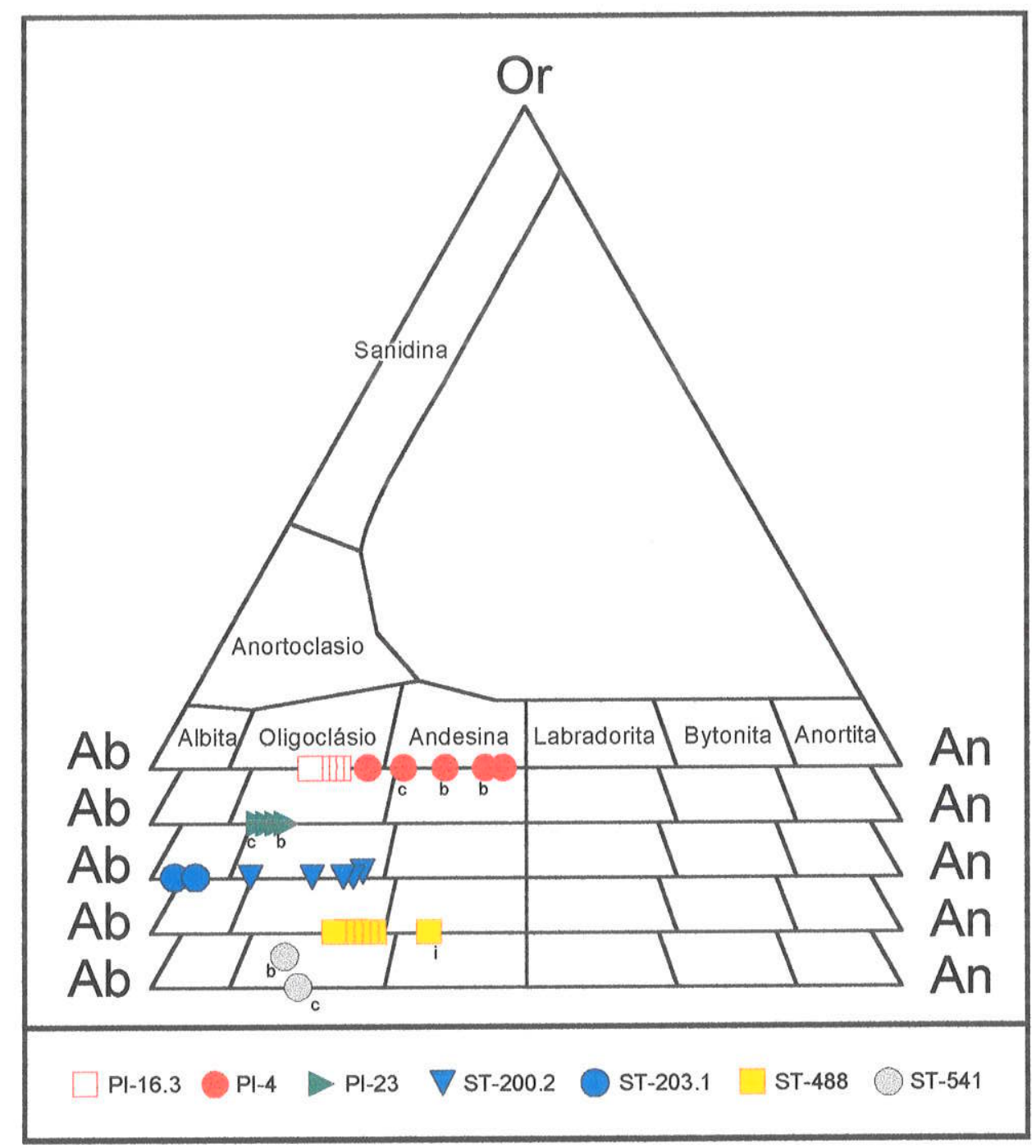

Fig. 10) Representação dos feldspatos analisados em metassedimentos no diagrama AlbitaOrtoclásio-Anortita. Símbolos: cor vermelha - Sequência Piancó; verde - Sequência Santana dos Garrotes; azul - Complexo Riacho Gravatá, Amêndoa Macacos-Piaus; amarelo - Xistos Sertânia; cinza - Complexo Riacho Gravatá, Amêndoa Serra da Pinheira. 


\section{D) Granadas:}

Granadas analisadas em nos metassedimentos da área do presente trabalho (Tabela 10), pertencem a série almandina-piropo-espersartita-grossulária (valores de $\mathrm{Al}^{\mathrm{V}}$ são aproximadamente iguais a 2 cátions por unidade de fórmula estrutural).

Os dados analíticos estão esquematicamente representados nos diagramas triangulares Almandina-Piropo-Espersartita e Almandina-Piropo-Grossulária (Fig. 11).

Observa-se que as granadas da Sequência Piancó (amostras Pl-4 e Pl-16.3), onde ocorre sillimanita e evidências de anatexia local, são relativamente mais ricas em $\mathrm{Mg}$ do que as granadas da Sequência Santana dos Garrotes (amostras ST-62, ST-27.1 e ST-26), e mostram um zoneamento composicional com o núcleo mais rico em $\mathrm{Mg}$ e a borda mais rica em $\mathrm{Fe}$ e $\mathrm{Mn}$. As granadas da amostra PI-23, localizada na Sequência Santana dos Garrotes, apresentam composição intermediária entre os dois grupos anteriormente citados, indicando que a temperatura do metamorfismo aumenta para noroeste dentro deste domínio do Complexo Cachoeirinha.

Na Amêndoa Serra da Pinheira do Complexo Riacho Gravatá, a cerca de $3 \mathrm{Km}$ ao norte da cidade de Santa Rita, as granadas analisadas apresentam composição $\mathrm{Al}_{69-72} \mathrm{Sp}_{1-2} \mathrm{Py}_{5-}$ ${ }_{6} \mathrm{Gr}_{21-25}$. Já na Amêndoa Macacos-Piaus as granadas das amostras ST-200.1, ST-203.1 e ST205.2 apresentam o núcleo ligeiramente enriquecido em Fe, enquanto na amostra ST-314 o centro é mais rico em $\mathrm{Mn}$ e Ca e empobrecido em Fe e Mg.

Nos xistos Sertânia (amostra ST-488) as granadas analisadas são mais ricas em Mg e, assim como as da Sequência Piancó, ocorrem associadas a sillimanita.

\section{E) Micas-Brancas:}

Os dados analíticos das micas brancas, recalculados para 11-oxigênio com todo ferro considerado como $\mathrm{Fe}^{2+}$, estão listados na Tabela 11 e plotam no campo da muscovita-fengita. (Fig. 12)

Micas brancas são descritas, normalmente em lâmina delgadas, orientadas segundo a foliação principal, por vezes em intima associação com biotitas. Mais raramente, descreve-se porfiroblástos de muscovitas crescidos tardiamente a foliação principal e orientados oblíquos a perpendiculares a esta (Pl-4, ST-541, ST-337, ST-337 e ST-314). 


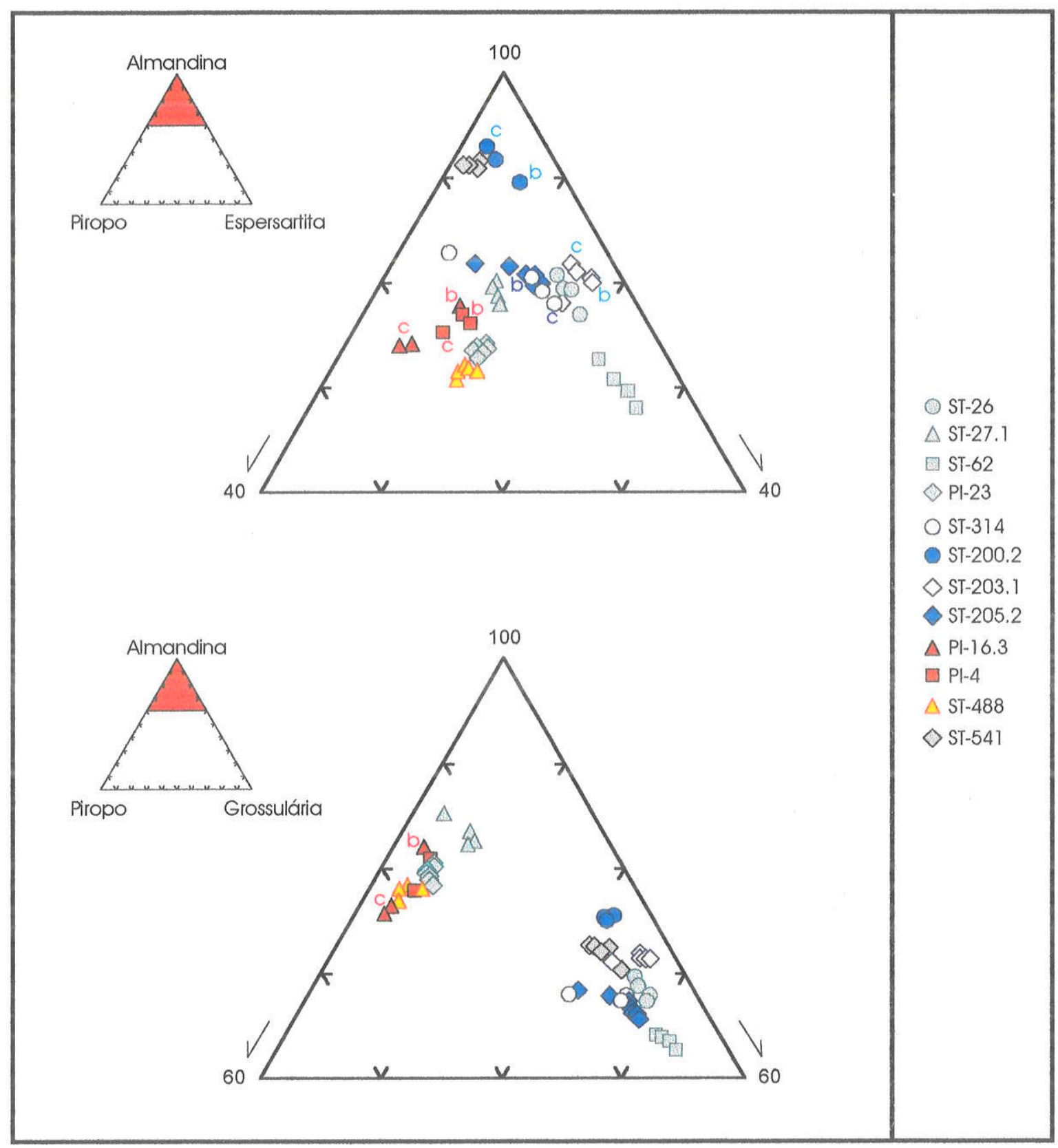

Fig. 11) Representação das granadas em metassedimentos da área do presente nos diagramas Almandina-Piropo-Espersartita e Almandina-Piropo-Grossulária. Símbolos: cor vermelha - Sequência Piancó; verde - Sequência Santana dos Garrotes; azul - Complexo Riacho Gravatá, Amêndoa Macacos-Piaus; amarelo - Xistos Sertânia; cinza - Complexo Riacho Gravatá, Amêndoa Serra da Pinheira. 


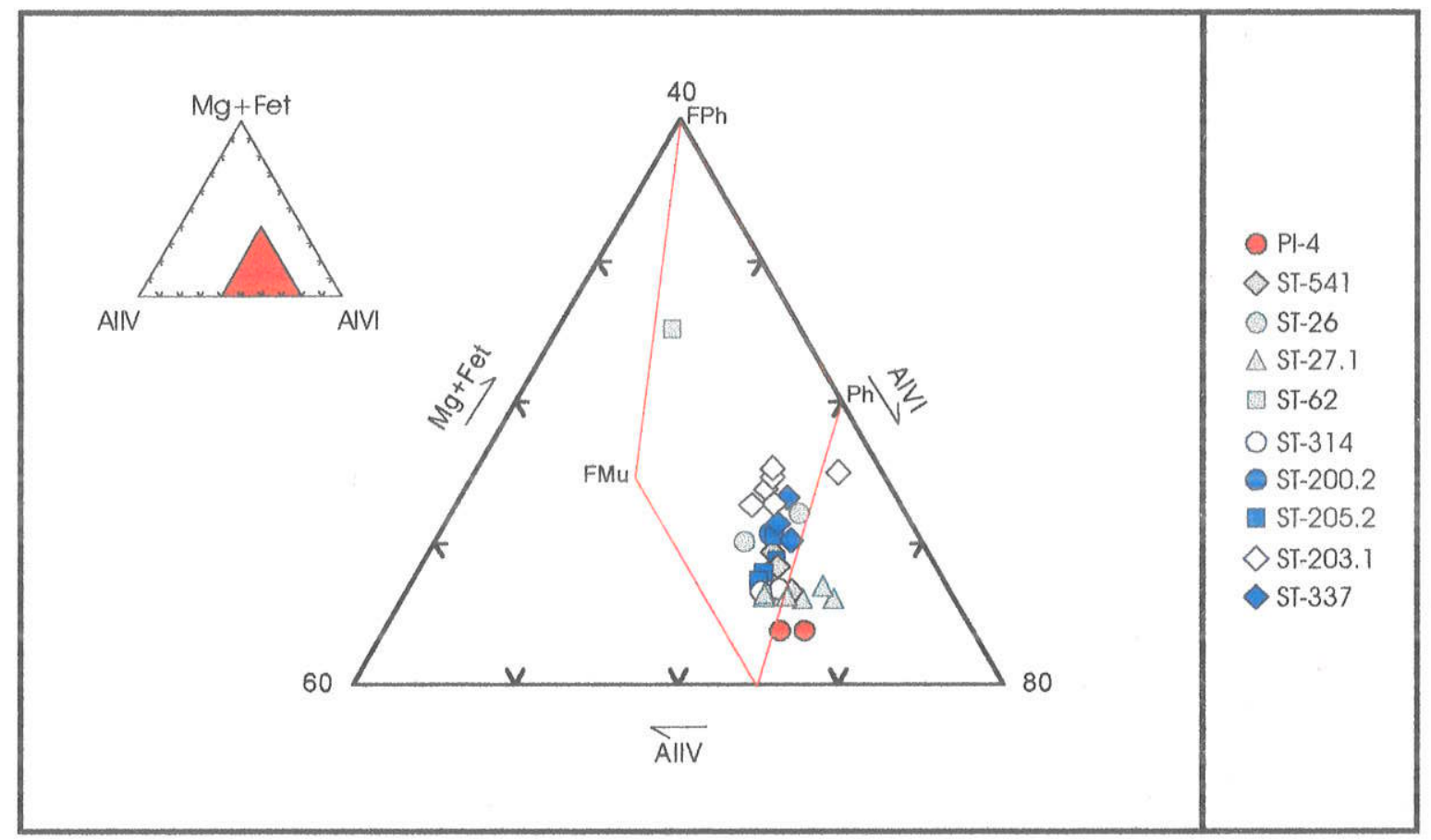

Fig. 12) Classificação das micas brancas, segundo Deer et al (1978). Símbolos: cor vermelha Sequência Piancó; verde - Sequência Santana dos Garrotes; azul - Complexo Riacho Gravatá, Amêndoa Macacos-Piaus; cinza - Complexo Riacho Gravatá, Amêndoa Serra da Pinheira. 


\section{IV.2.1 Química Mineral das Rochas Metabásicas}

Feldspatos, anfibólios, granadas, biotitas e cloritas de algumas rochas metabásicas, representadas por anfibolitos e granada-anfibolitos, descritas no Complexo Riacho Gravatá, foram analisados pontualmente na microssonda eletrônica para fins de quantificaçăo do metamorfismo a que estiveram submetidas. Estes resultados permitiram uma caracterização química destes minerais apresentada a seguir.

\section{A) Feldspatos:}

As análises químicas dos feldspatos analisados nas rochas metabásicas são apresentadas na Tabela 12 (recalculados para 8-oxigênios) e a composição química destes em termos das moléculas de albita-ortoclásio-anortita representadas na Figura 13.

Das metabásicas descritas na Amêndoa Serra da Pinheira, apenas três exemplares tiveram seus feldspatos analisados: as amostras ST-530 e ST-475, localizadas próximas ao Complexo Serra Talhada (ortognaisses e migmatitos), e a amostra ST-AC-35.2, localizada a cerca de $9 \mathrm{Km}$ a norte da cidade de Manaira.

Os feldspatos analisados na amostra ST-530, são plagioclásio de composição andesina $\left(A n_{40-45}-A b_{60-54}\right)$, e microclina com composição Or $_{93}-A b_{7}$.

$\mathrm{Na}$ amostra ST-475 o plagioclásio apresente zonação inversa com a borda mais cáicica $\left(A n_{30-40}-A b_{60-70}\right)$ que o núcleo $\left(A n_{23}-A b_{77}\right)$, evidenciando um relativo aumento de temperatura, possivelmente relacionado a estrutura distensiva associada a terceira fase de deformação que promoveu a ascensão do Complexo Serra Talhada, mais quente.

$\mathrm{Na}$ amostra ST-35.2 o plagioclásio presente é albita $\left(A n_{2-7}-A b_{98-93}\right)$ sugerindo temperaturas mais amenas ou pressões mais elevadas ao norte da cidade de Manaíra.

Na Amêndoa Macacos-Piaus um maior número de feldspatos foram analisados (de sul para norte, amostras: ST-305.E, ST-206.2, ST-312.E, ST-316.A, ST-6.A, ST-322, ST-338.B e ST-338.C). Os plagioclásios das rochas metabásicas analisados nesta amêndoa, independente da mineralogia, apresentam composição variando de albita a oligociásio ( $\mathrm{An}_{29-2-}$ $\left.A b_{71-98}\right)$. Em algumas das amostras analisadas, constatou-se uma zonação inversa com a borda mais cálcica que o núcleo, o que pode indicar aumento de temperatura e/ou diminuição de pressão, e na amostra ST-6-A, além de plagioclásio, analisou-se ortoclásio com composição $\mathrm{Or}_{98}-\mathrm{Ab}_{2}$.

Na Amêndoa Serra do Mocambo, extremo sul, os feldspatos analisados (AF-53.F) mostram zonação inversa e composição variando de oligoclásio a andesina $\left(A n_{34-30}-A b_{66-70}\right)$. 


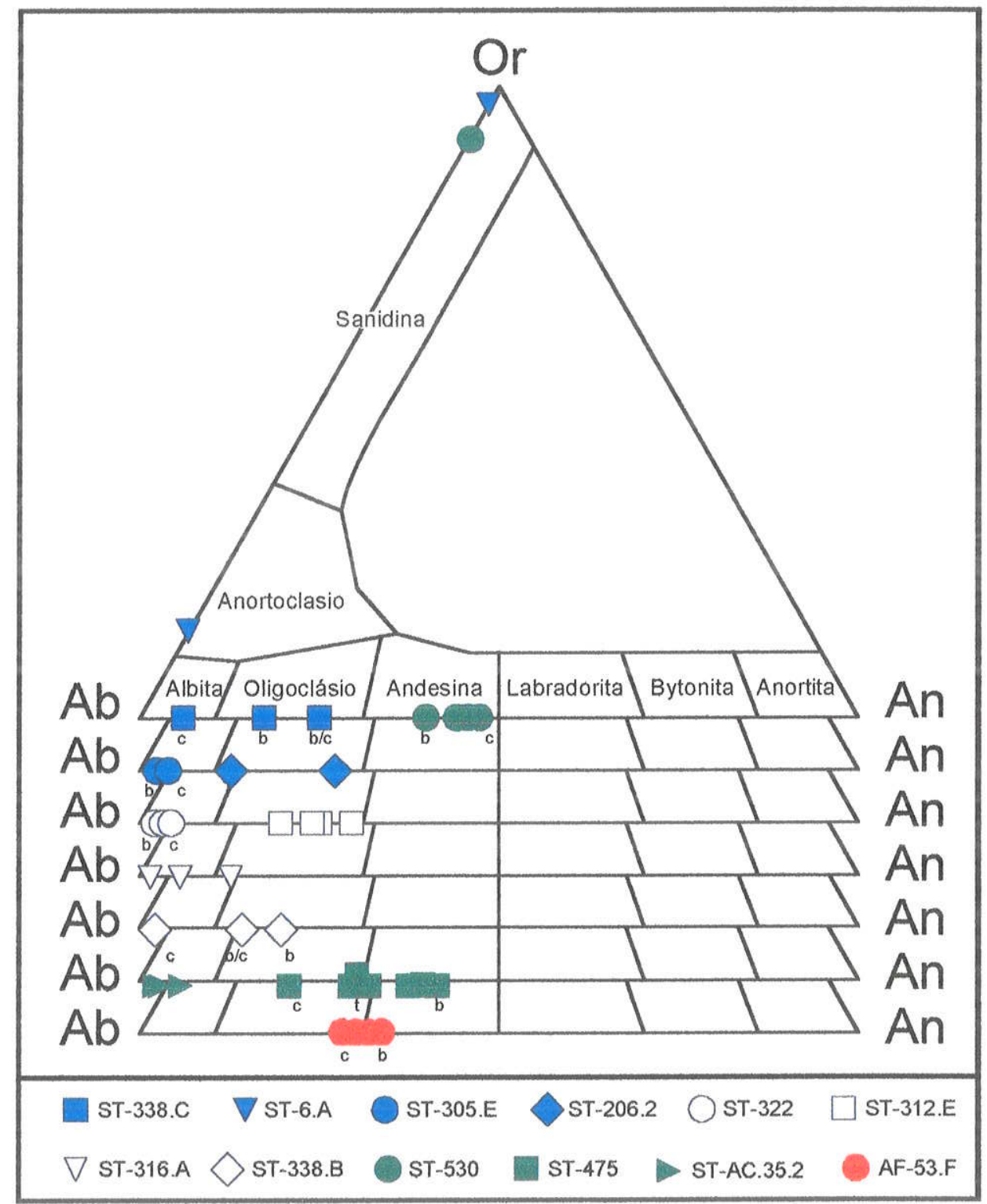

Fig. 13) Representação dos feldspatos das metabásicas do Complexo Riacho Gravatá no diagrama Albita-Ortoclásio-Anortita. Símbolos: azul - Amêndoa Macacos-Piaus; verde Amêndoa Serra da Pinheira; vermelho - Amêndoa Serra do Mocambo. 


\section{B) Anfibólios:}

Os anfibólios analisados nas metabásicas do Complexo Riacho Gravatá foram recalculados de diversas maneiras seguindo a metodologia do termômetro ou do barômetro utilizado para o estabelecimento das temperaturas e pressões a que estas rochas estiveram submetidas (vide seção IV.3, deste capítulo).

Entretanto para fins da classificação dos anfibólios, utilizou-se o cálculo da formula estrutural recalculada para 23-oxigênios com o $\mathrm{Fe}^{3+}$ estimado como o valor médio, conforme proposto por Leake et al (1997), listados na Tabela 13. Segundo estes autores os anfibólios analisados são cálcicos e monoclínicos com $(\mathrm{Ca}+\mathrm{Na}) \mathrm{B} \geq 1,00,1,5<(\mathrm{Na}) \mathrm{B}<0,5 \mathrm{e}$, geralmente, $(\mathrm{C} a) B \geq 1,5$. Além disto todos os anfibólios apresentam valores de $\mathrm{Ti}<0,5$.

Os anfibólios de anfibolitos das amêndoas Macacos-Piaus e Serra da Pinheira (porção sul) projetados nos diagramas de classificação de Leake et al (1997) com ( $N a+K) A \geq 0,5$ (Fig. 14a) correspondem a Mg-hornblenda e tschermarquita, enquanto que aqueles dos granada anfibolitos (ST-312.E, ST-316.A e ST-338.B) possuem composição de Fe-tschermarquita, sugerindo que a perda de $\mathrm{Mg}$ esteja relacionada a cristalização da granada. Os anfibolitos da Amêndoa Serra da Pinheira (porção norte, região de Manaíra) possuem composiçōes de actinolita. No diagrama de Leake et al (1997) para ( $\mathrm{Na}+\mathrm{K}) \mathrm{A}<0,5$ (Fig. 14b) a composição dos anfibólios das metabásicas da Amêndoa Macacos-Piaus encontra-se no campo da Fepargassita $\left(\mathrm{Al}^{\mathrm{V} /}>\mathrm{Fe}^{3+}\right)$, enquanto que na Amêndoa Serra da Pinheira-sul, os anfibólios estão no campo de Mg-hastingsita (alguns da amostra ST-475.A) e pargasita.

Apesar de terem sido feitas análises de bordo e centro em algumas minerais, estes não apresentaram maiores variações composicionais.

No gráfico $\mathrm{Al}^{\mathrm{N} \times \mathrm{Al}} \mathrm{Al}^{\mathrm{V}}$ (Fig. 15) observa-se que os anfibólios das rochas metabásicas da Amêndoa Macacos-Piaus alcançam valores de $A l^{V i}$ mais elevados que os anfibólios das amostras da Amêndoa Serra da Pinheira, sem no entanto apresentarem um padrão de zoneamento evidente entre a borda e o núcleo do grão. Segundo Sorensen (1989) e Hollister et al (1987) os valores de $\mathrm{Al}^{\mathrm{V}}$ estão diretamente relacionado com a pressão. Por outro lado as metabásicas do Complexo Riacho Gravatá, na Amêndoa Serra da Pinheira, alcançam teores de $\mathrm{Al}^{\mathrm{N}}$ mais elevados (sem zoneamento nos grão estudados), o que, segundo Blundy et al (1990), está diretamente relacionado a temperatura. Cabe ressaltar que os maiores valores de $\mathrm{Al}^{\mathrm{IV}}$ foram obtidos para a amostra ST-475.A, em anfibólios associados a textura quelifítica (Foto 23). Apesar de questionada por Blundy et al (1990), a relação do conteúdo de $A l^{\sqrt{i}}$ com a pressão mostrou-se coerente com os cálculos barométricos (seção IV.4), assim como a relaçăo do $\mathrm{Al}^{\mathrm{V}} \mathrm{c}$ com a temperatura. 

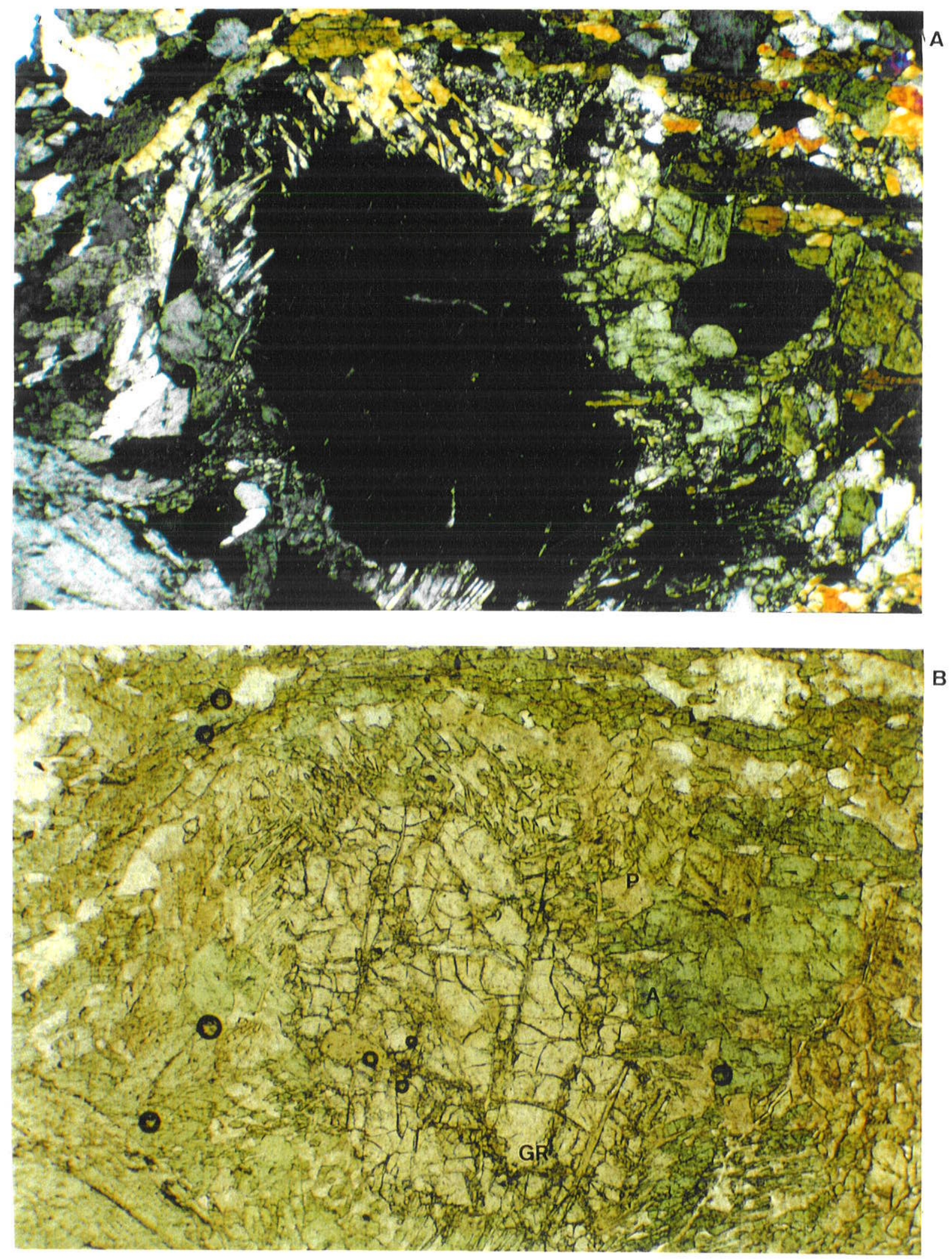

Foto 23) Corona de reação (textura quelifítica) envolvendo granada (GR), anfibólio (A) e plagioclásio $(P)$ em granada anfibolito do Complexo Serra da Pinheira, Amêndoa Serra da Pinheira-sul. (A - nicóis X, B - nicóis //) 

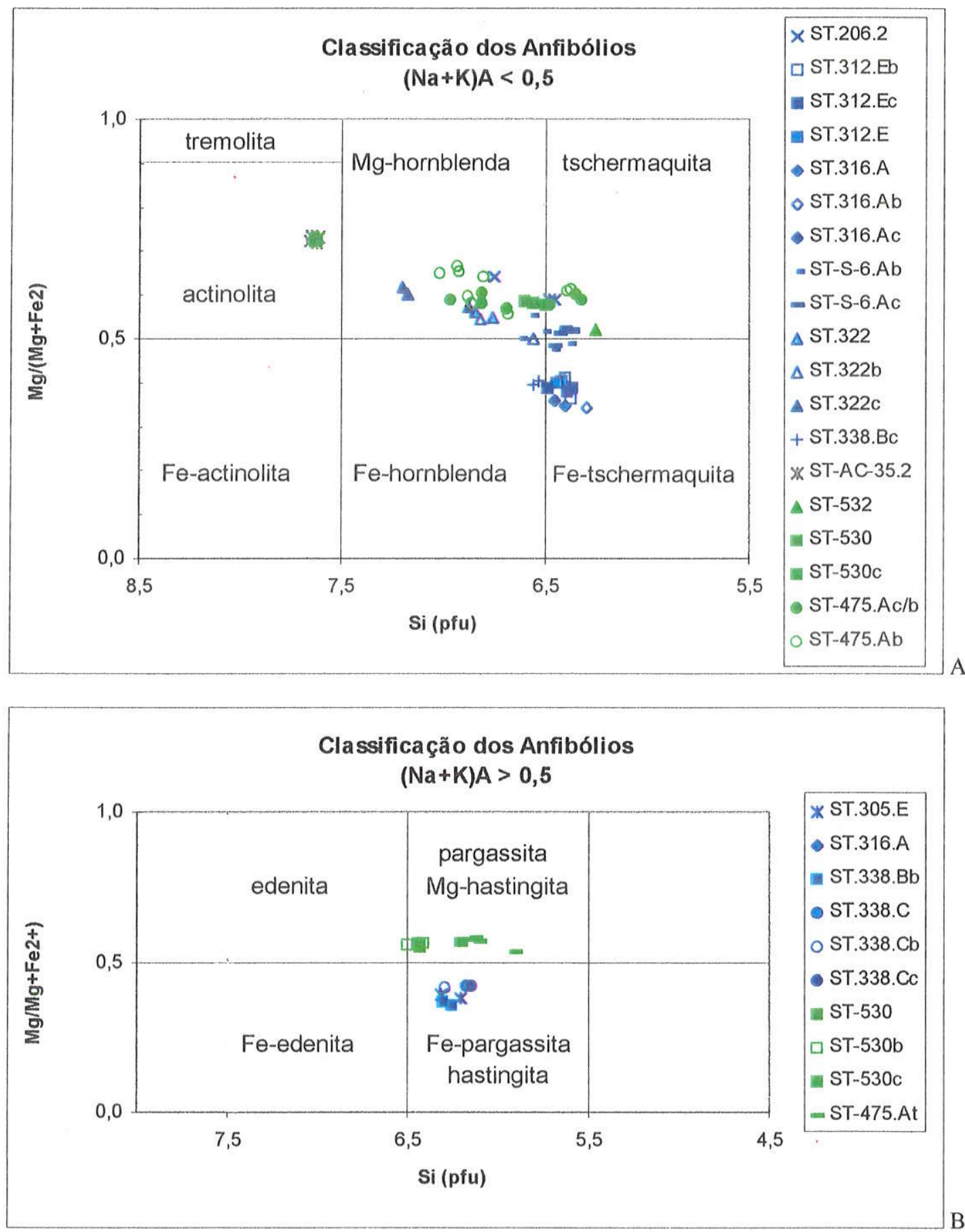

Fig 14) Classificação dos anfibólios dos Complexo Riacho Gravatá segundo Leake et al (1997). Símbolos: azul - Amêndoa Macacos-Piaus; verde claro - Amêndoa Serra da Pinheira-sul; verde escuro - Amêndoa Serra da Pinheira, a norte da cidade de Manaíra. 


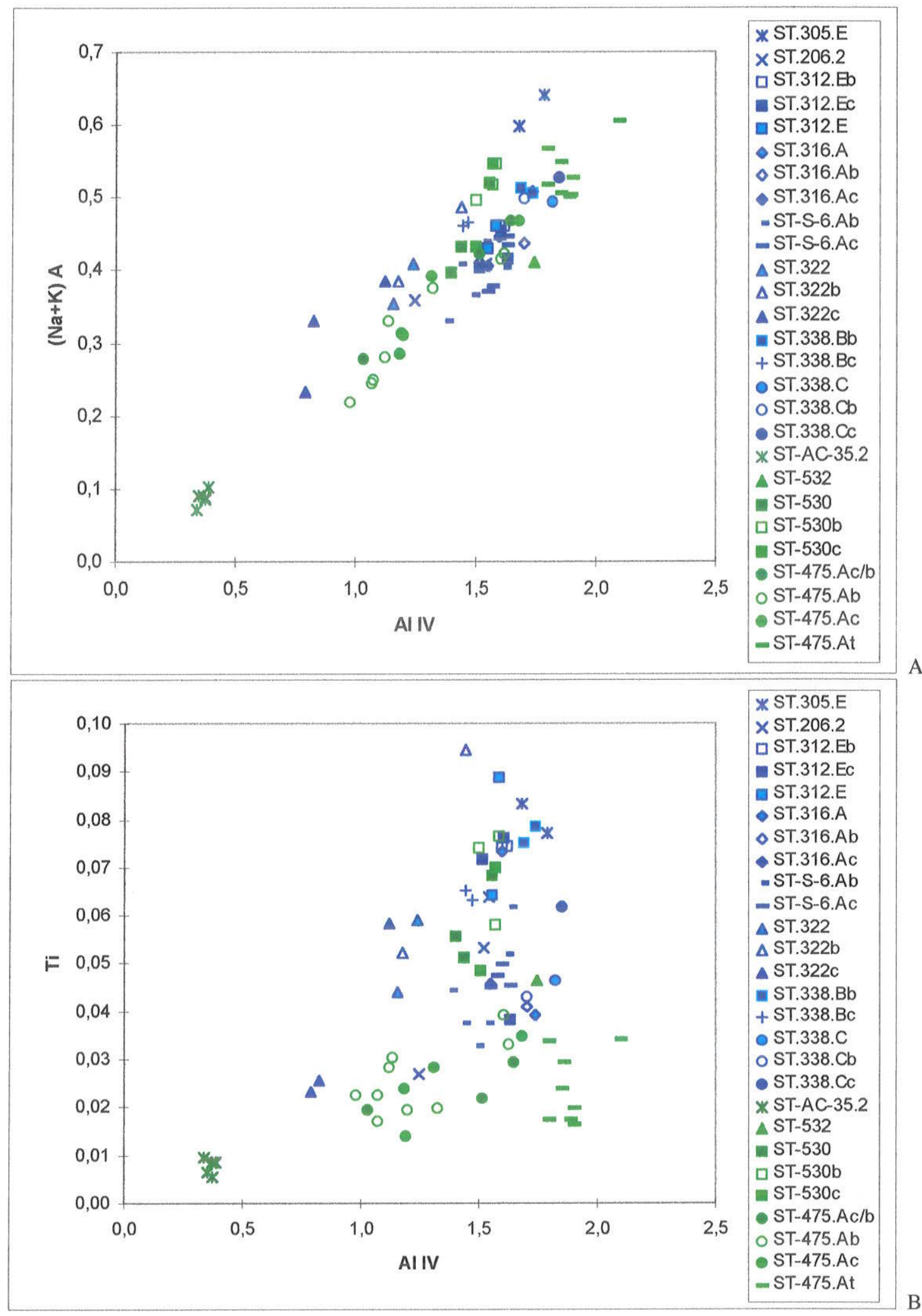

Fig 15) Anfibólios do Complexo Riacho Gravatá plotados nos gráfico AllV x (Na+K)A (A) e AllV x Ti (B) e AllV x AIVI(C). Simbologia a mesma da Fig. 14. 


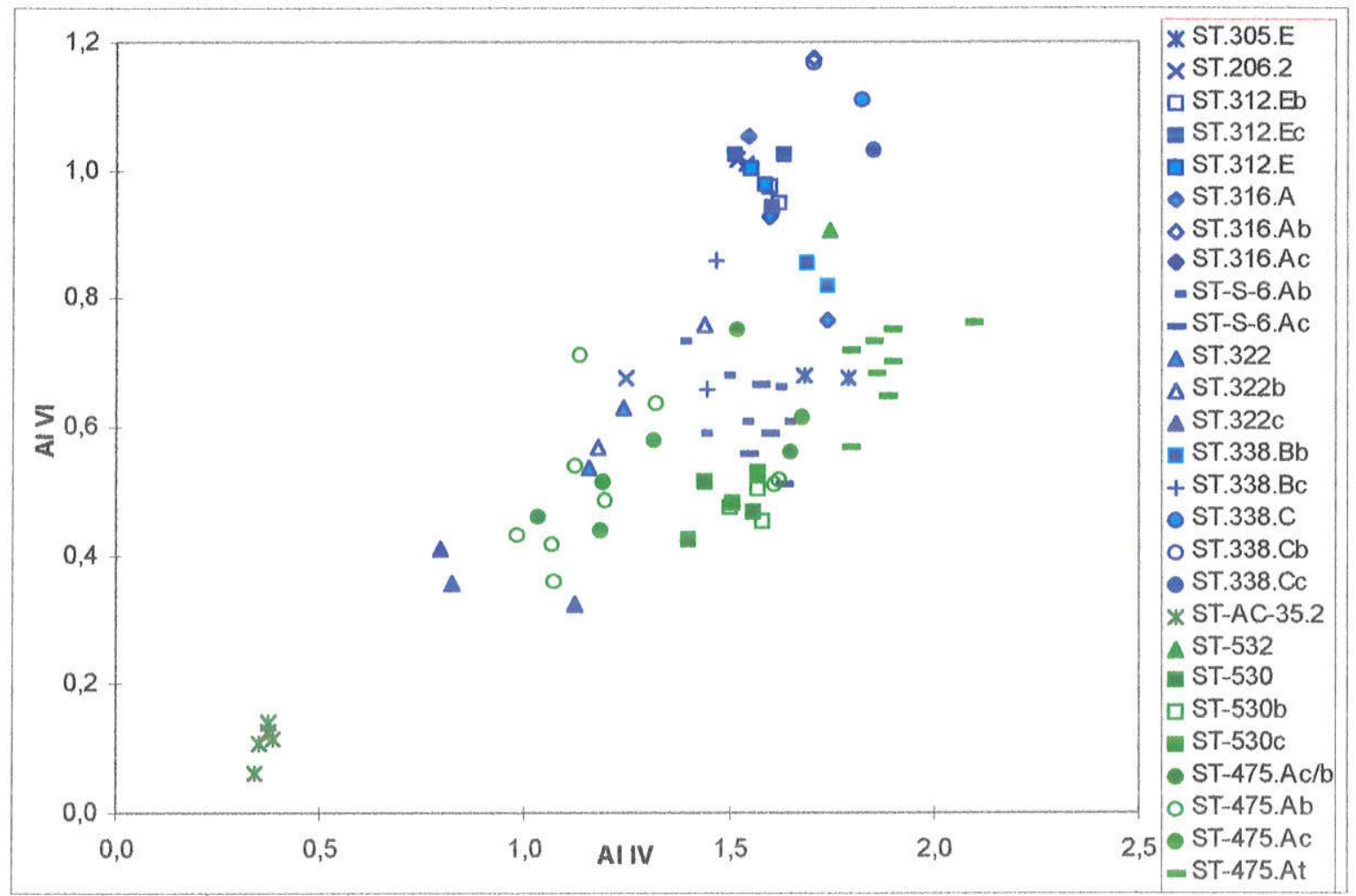

Fig. 15) Continuação.

\section{C) Granadas:}

Granadas analisadas em granada-anfibolitos do Complexo Riacho Gravatá nas três amêndoas (Tabela 14), pertencem a série almandina-piropo-espersartita-grossulária (valores de $\mathrm{Al}^{\mathrm{V}} \mathrm{s}$ são aproximadamente iguais a 2 cátions por unidade de fórmula estrutural).

Os dados analíticos estão representados nos diagramas triangulares Almandina-PiropoEspersartita e Almandina-Piropo-Grossulária (Fig. 16). Com base nestes dados, pode-se observar que de um modo geral as granadas analisadas em amostras próximas ao Complexo Serra Talhada (ST-475 e ST-332) são mais enriquecidas em moléculas de piropo do que aquelas localizadas na Amêndoa Macacos-Piaus, sugerindo condições metamórficas mais elevadas. Na amostra ST-475, localizada próxima ao Complexo Serra Talhada, observa-se um discreto zoneamento composicional, com o núcleo ligeiramente mais rico na fração molar de ferro $\left(X_{F_{e}}\right)$ e manganês $\left(X_{M n}\right)$ e as bordas relativamente enriquecidas em $X_{M g}$ e $X_{C a}$, sugerindo relativo aumento de temperatura quando do crescimento do grão. 
$\mathrm{Na}$ Amêndoa Macacos-Piaus as granadas das metabásicas são relativamente mais ricas em almandina e espessartita que as granadas das metabásicas da Amêndoa Serra da Pinheira. Em algumas amostras observa-se um discreto zoneamento químico (ST-312.E e ST338.B), onde o núcleo é ligeiramente mais enriquecido em $\mathrm{Mn}$ e bordas mais ricas em $\mathrm{Fe} \mathrm{e} \mathrm{Mg}$, mantendo-se o Ca mais ou menos constante.

Na Amêndoa Serra do Mocambo, granada foi analisada em uma única amostra de granada-anfibolito (AF-53.F) e apresentou um nítido zoneamento químico com aumento do $X_{\text {Mn }}$ as expensas das demais frações molares, do núcleo para a borda.

\section{D) Cloritas e Biotitas:}

As análises das cloritas de rochas metabásicas, recalculadas para 14-oxigênios com todo ferro considerado como $\mathrm{Fe}^{2+}$, são apresentadas na Tabela 7. Estas caem nos campos da ripidolita, picnoclorita e diabanita (Fig. 8) no gráfico de classificação das cloritas frescas (Deer et al, 1978). As cloritas substituem granadas a partir de fraturas, substituem biotitas e, mais raramente, anfibólios, também em fraturas e clivagens e, possivelmente, relacionam-se a processos de alteração (ST-322, ST-312.E e ST-338.B).

As biotitas estão relacionadas a processos de retrometamorfismo e ocorrem associadas a anfibólios e, mais raramente, a granadas. Como via de regra estão cloritizadas (processo deutérico), somente na amostra ST-206.2, localizada na Amêndoa Macacos-Piaus, as análises de biotitas apresentaram uma estequiometria coerente (Tabela 8 ). 

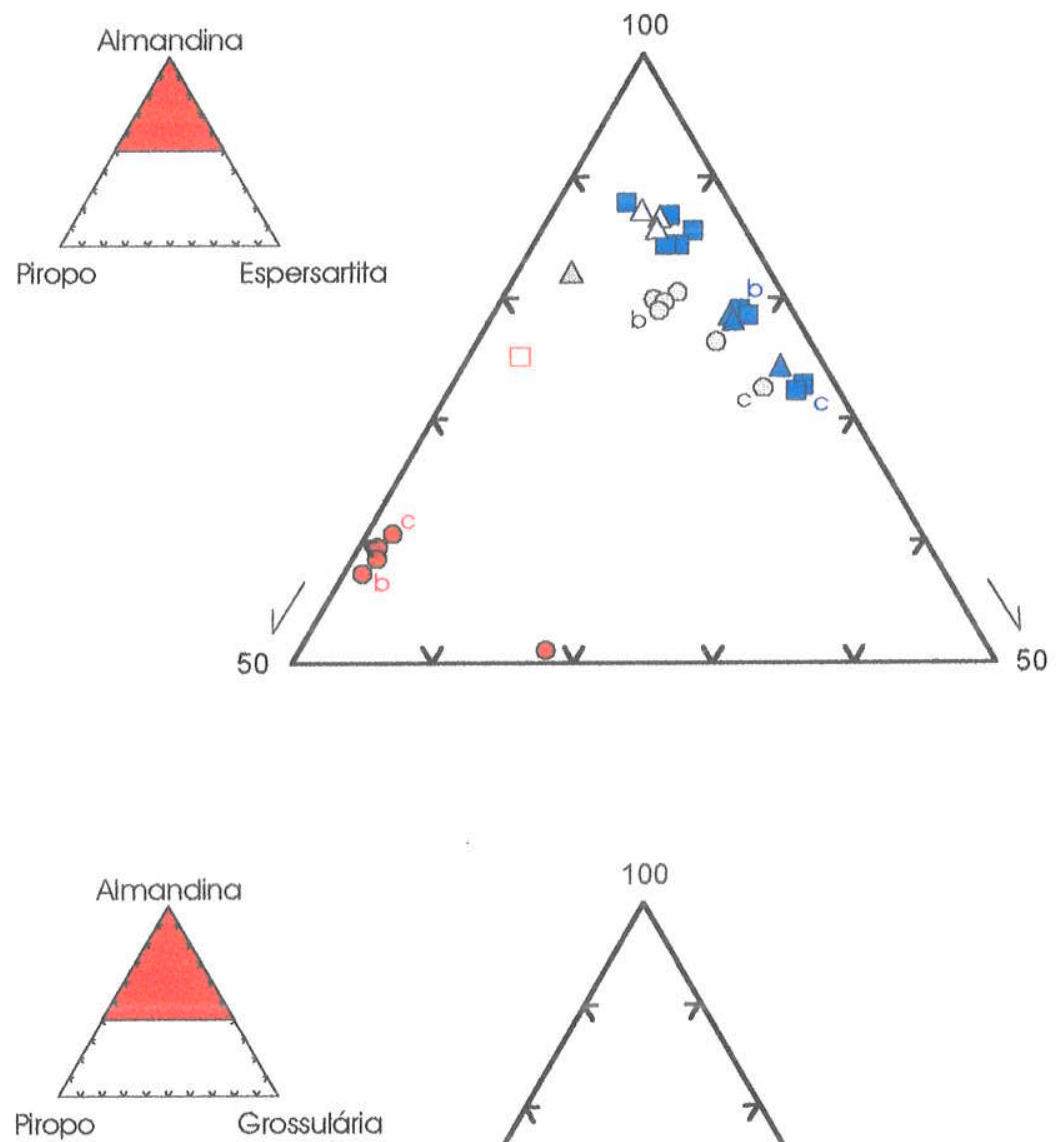

ST-312.E

Fig. 16) Representação das granadas em metabásicas nos diagramas Almandina-PiropoEspersartita e Almandina-Piropo-Grossulária. Símbolos: cor vermelha - Complexo Riacho Gravatá, Amêndoa Serra da Pinheira-sul; cinza - Complexo Riacho Gravatá, Amêndoa Serra do Mocambo; azul - Complexo Riacho Gravatá, Amêndoa Macacos-Piaus. 


\section{IV.3 GEOTERMOMETRIA E GEOBAROMETRIA}

A caracterização das condições de temperatura e pressão do metamorfismo a que uma rocha esteve submetida é um aspecto de extrema importância no estudo da evolução tectônica de terrenos metamórficos.

A base para determinação das temperatura e pressão está na definição das assembléias minerais em equilibrio, através de microestruturas e microtexturas observadas em lâmina delgada, permitindo organizar a (re)cristalização dos minerais em pré, sin e póscinemáticos a uma determinada fase de deformação (Zwart, 1962; Bell \& Rubenach, 1983; Paschier et al, 1996, entre tantos outros). A partir daí, a composição quimica pontual das diferentes fases minerais em equilíbrio permite a aplicação de termômetros e barômetros compatíveis com as paragêneses definidas.

\section{IV.3.1 REVISÃO DOS GEOTERMÔMETROS E GEOBARÔMETROS APLICADOS}

\section{A) Geotermômetros Granada-Anfibólio:}

Graham \& Powell (1984), propõem um termômetro empírico cuja a base é a troca catiônica do ferro e magnésio entre a granada e a hornblenda, segundo a fórmula Fe-pargasita + piropo+ pargasita + almandina, interpretada como uma solução sólida ideal. O termômetro foi calibrado para rochas entre o fácies anfibolito a granulito em temperaturas inferiores a $850^{\circ} \mathrm{C} \mathrm{e}$ pressões entre 8 - $10 \mathrm{kbars}$. Os autores tratam todo o ferro como $\mathrm{Fe}^{2+}$, porque nas condições mencionadas a atividade do oxigênio é baixa, os cálculos para estimativas de $\mathrm{Fe}^{3+}$, geral uma super-estimativa, acarretar numa super-estimativa da temperatura calculada, e porque a razão $\mathrm{Fe}^{3+} / \mathrm{Fe}^{2+}$ é baixa em hornblendas coexistindo com granadas. As restrições para a aplicação deste termômetro são: não ocorrência de texturas de desequilibrio entre a granada e o anfibólio, para minimizar os efeitos da não idealidade da solução sólida do $\mathrm{Fe}-\mathrm{Mg}$ nos anfibólios, que pode ocasionar uma super-estimativa da temperatura; ausência de clinopiroxênio; fração molar do magnésio na granada $\left(X_{M g}\right)$ têm que ser menor que 0,$1 ; 0$ sódio na posição estrutural M4 (NaM4) do anfibólio deve ser maior que 0,09 ; o cálcio na posição M4 (CaM4) deve ser baixo; e a soma do sódio com o potássio na posição $\mathrm{A}(\mathrm{Na}+\mathrm{K}) \mathrm{A}$ deve ser menor que 0,4 por unidade de fórmula (pfu).

A granada é recalculada para 12-oxigênios e o anfibólio para 23-oxigênios, ambos tendo todo ferro como $\mathrm{Fe}^{2+}$, sendo o cálculo da temperatura feito através da equação: 
$T(K)=\left(2880+3280 X_{C a}{ }^{g r}\right) / \ln K_{D}+2,426$

onde: $K_{D}=\left(X_{F \theta} / X_{M g}\right)^{g r} /\left(X_{F \theta} / X_{M g}\right)^{\text {hb }}$

Perchuck (1991) reedita o termômetro empírico granada-anfibólio de Perchuck (1976), aplicável para estimativas de temperaturas em metabasitos do fácies granulito, eclogito, granada-anfibolito e xisto-azul. Segundo o autor, acima de $500^{\circ} \mathrm{C}$ o equilibrio da reação: hornblenda-Mg + granada-Fe $=$ granada-Mg + hornblenda-Fe, depende da fração molar do magnésio nos minerais, podendo a temperatura ser estimada pela equação:

$T(K)=3330+\left(\ln K_{D}+2,33\right)$

onde: $K_{D}=\left(X_{M g} / 1-X_{M g}\right)^{\text {hb }} \cdot\left(1-X_{M g} / X_{M g}\right)^{g r}$

Abaixo de $500^{\circ} \mathrm{C}$ a correlação entre $\ln K_{D}$ e $1 / \mathrm{T}$ é válida, mas o coeficiente de correlação decresce. As restrições para a aplicação deste geotermômetro são, além da temperatura superior a $500^{\circ} \mathrm{C}$, que $\circ \mathrm{X}_{\mathrm{Ca}}{ }^{\mathrm{gr}}$ seja, igual a $0,212 \pm 0,05$, que $\circ \mathrm{X}_{\mathrm{Mn}}{ }^{\mathrm{gr}}$ seja, aproximadamente, igual a 0,08 , que a razão $\mathrm{Fe} / \mathrm{Mg}$ no anfibólio, varie dentro dos limites da hornblenda, e que $X_{M g}{ }^{g r} / X_{M g}{ }^{\text {hb }}=1$. O cálculo da fórmula estrutural para granada é com base em 12-oxigênios, para o anfibólio é com base anidra para 23-oxigênios, em ambos todo ferro é considerado como $\mathrm{Fe}^{2+}$.

A diferença básica entre o termômetro do Perchuck (1991) e Grahan \& Powell (1984) está na restrição de que $\circ \mathrm{X}_{c a}{ }^{g r} \cong 0,212$, imposta pelo primeiro autor, segundo o qual os componentes adicionais nos minerais coexistentes, influenciam nas temperaturas calculadas.

No presente trabalho, não foi possível, em função das restrições impostas, calcular temperaturas utilizando os termômetros acima citados em uma mesma rocha e assim tecer comparações entre eles. Entretanto, pôde-se calcular temperaturas para rochas metabásicas de uma mesma amêndoa (Amêndoa Macacos-Piaus, amostras ST-312.E e ST-316.A, vide Tabela 15) que forneceram temperaturas aproximadamente iguais $\left(541^{\circ} \mathrm{C}\right.$ e $536^{\circ} \mathrm{C}$, respectivamente) sugerindo uma boa correspondência entre estes termômetros, quando aplicados dentro das especificações.

\section{B) Geotermômetros Anfibólio.Plagioclásio:}

Blundy \& Holland (1990) propõem um termômetro semi-empírico levando em consideração o conteúdo de $\mathrm{Al}^{\mathrm{N}}{ }^{\mathrm{N}}$ do anfibólio coexistente com plagioclásio e quartzo, que pode ser aplicado a rochas metamórficas do fácies xisto verde ao granulito e em rochas ígneas de composição ácida a básica. Os autores utilizam dados experimentais e naturais que mostram 
que as principais modificações observadas na estrutura dos anfibólios em função da temperatura referem-se ao preenchimento das posições do $\mathrm{Na}^{\mathrm{A}}$ e do $\mathrm{Al}^{\mathrm{T1}}$ e $\mathrm{Si}^{\mathrm{T1}}$.

Os termômetros foram calibrados para as reações: edenita +4 quartzo $=$ tremolita + albita e pargassita +4 quartzo = hornblenda + albita, e para o cálculo utiliza-se a fórmula: $T(K)=(0,677 P($ Kbars $)-48,98+Y) /(-0,0429-0,008314 \ln K)$ onde: $K=X_{\mathrm{Na}}{ }^{\text {plag }}$. (Si-4) $/(8-\mathrm{Si})$ $Y=0\left(\right.$ se $\left.X_{N a}^{\text {plag }}>0,5\right)$ e $Y=8,06+25,5 .\left(1-X_{n a}^{\text {plag }}\right)^{2}\left(\right.$ se $\left.X_{N a}^{\text {plag }}<0,5\right)$

O termômetro é pouco preciso para análises onde o $\mathrm{Fe}^{3+}$ é recalculado, devendo-se neste caso utilizar a média entre os valores obtidos quando se assume que o total de cátions é 13-CNK para 23-oxigênios e os valores obtidos quando se assume que o total de cátions é 15NK. As restrições para sua aplicação são: a temperatura entre $500^{\circ}-1000^{\circ} \mathrm{C}$ (com erros de \pm $75^{\circ} \mathrm{C}$ ); $\circ \mathrm{X}_{\mathrm{Ca}}{ }^{\text {plag }}$ deve ser menor que 0,92; o Sianf pfu deve ser menor que 7,8; e o Ca pfu deve ser maior que 1,3. Este termômetro foi bastante criticado, pois para rochas com anfibólios de composição similares as utilizadas pelos autores, os resultados obtidos foram bons, mas para rochas com hornblenda aluminosa coexistindo com plagioclásio (especialmente em granada anfibolitos) foram observados erros superiores $400^{\circ} \mathrm{C}$.

Holland \& Blundy (1994) revêm o termômetro por eles proposto em 1990, e levando em consideração a não idealidade das interações dos anfibólios cálcicos no par anfibólioplagioclásio, propõem o equilíbrio das reações: (a) edenita +4 quartzo $=$ tremolita + albita (aplicável para rochas saturadas em sílica) e (b) edenita + albita = richtcherita + anortita (para rochas saturadas e insaturadas em sílica). Examinam as interações dos elementos $\mathrm{K}-\mathrm{Na}-\mathrm{Ca}-$ $\mathrm{Mg}-\mathrm{Fe}^{3+}-\mathrm{Fe}^{2+}-\mathrm{Al}-\mathrm{Si}$ nas posições $\mathrm{A}, \mathrm{M} 4, \mathrm{M} 1, \mathrm{M} 3, \mathrm{M} 2$ e $\mathrm{T} 1$ dos anfibólios, a partir de dados experimentais e naturais, onde a temperatura e a pressão são restritas. Os referidos autores ignoram o magnésio e o titânio, pois seus efeitos são insignificantes em anfibólios pobres nestes elementos, e a influência destes seria mais viável em temperaturas elevadas e/ou em anfibólios pobres em cálcio.

A composição dos anfibólios é bastante variável, incluindo o anfibólio tschermarquita de granada-anfibolitos, que apresentavam problemas no termômetro de Blundy \& Holland (1990). O cálculo estrutural do anfibólio é feito com base anidra para 23-oxigênios, onde o $\mathrm{Fe}^{3+}$ é recalculado a partir dos métodos de Spear \& Kimball (1984) e Robinson et al (1982), seguido de mais duas restrições: $\left(\mathrm{Al}^{\mathrm{V}}, \mathrm{Ti}, \mathrm{Fe}^{3+}\right) \mathrm{M} 2$ e o CaM4 devem ser inferiores a 2 pfu.

Para o termômetro (a) as restriçōes são: temperatura entre $400^{\circ}$ e $900^{\circ} \mathrm{C}$; no anfibólio o $\mathrm{NaA}$ deve ser maior que 0,02 pfu, o $\mathrm{Al}^{\mathrm{VI}}$ deve ser menor que 1,8 pfu, o Si entre 6,0 e 7,7 pfu; 
e no plagioclásio o $X_{N a}$ deve ser menor que 0,9 pfu. $O$ erro analítico, geralmente, fica em torno de $50^{\circ} \mathrm{C}$ e a fórmula utilizada para o cálculo da temperatura é:

$T_{(a)}(K)=\left(-76,95+0,79 P+Y_{A b}+39,4 X_{N a}{ }^{\text {plag }}+22,4 X_{K}{ }^{A}+(41,5-2,89 P) \cdot X_{A l}{ }^{M 2}\right) /(-0,065-$ $0,0083144 \ln K)$

onde: $K=\left(27 . X_{D}{ }^{A} X_{S i}{ }^{T 1} X_{A b}{ }^{\text {plag }}\right) /\left(256 \cdot X_{N a}{ }^{A} X_{A i}{ }^{T 1}\right)$

$Y_{A b}=0\left(\right.$ se $\left.X_{A b}{ }^{\text {plag }}>0,5\right)$ e $Y_{A b}=12 \cdot\left(1-X_{A b}^{\text {plag }}\right)^{2}-3\left(\right.$ se $\left.X_{A b}^{\text {plag }} \leq 0,5\right)$

Já para o termômetro (b) a temperatura deve ser entre $500^{\circ}$ e $900^{\circ} \mathrm{C}$ e o $\mathrm{NaA}$ no anfibólio deve ser major que 0,03 pfu, sendo que as demais restrições e os erros analíticos são os mesmos do termômetro (a). A fórmula utilizada para o cálculo da temperatura neste caso é: $T_{(b)}(K)=\left(78,44+Y_{A b-N a}-33,6 X_{N a}^{\text {plag }}-(66,8-2,92 P) X_{A 1}{ }^{M 2}+78,5 X_{A 1}{ }^{\top 1}+9,4 X_{N a}^{\text {plag }}\right) /(0,0721-$ $0,0083144 \ln K)$

onde: $\mathrm{K}=\left(27 . \mathrm{X}_{\mathrm{Na}}{ }^{\mathrm{M} 4} \mathrm{X}_{\mathrm{Si}}{ }^{\top 1} \mathrm{X}_{\mathrm{An}}{ }^{\text {plag }}\right) /\left(64 . \mathrm{X}_{\mathrm{Ca}}{ }^{\mathrm{M} 4} \mathrm{X}_{\mathrm{Al}}{ }^{\mathrm{T}} \mathrm{X}_{\mathrm{An}}{ }^{\text {plag }}\right)$

$Y_{A b-N a}=3\left(\right.$ se $\left.X_{A b}^{\text {plag }}>0,5\right)$ e $Y_{A b-N a}=12 \cdot\left(2 X_{A b}^{\text {plag }}-1\right)+3\left(\right.$ se $\left.X_{A b}^{\text {plag }} \leq 0,5\right)$

Spear (1981) propõe um termômetro empírico a partir da reação: albita + tremolita = edenita +4 quartzo, onde o equilíbrio entre o plagioclásio, o anfibólio e o quartzo, estaria governado pela partição do sódio entre o plagioclásio e a posição estrutural $A$ do anfibólio, que varia com o metamorfismo de modo que $X_{N a}{ }^{A} /\left(X_{D}{ }^{A} \quad X_{A b}\right)$ aumenta com a temperatura. $A$ fórmula estrutural do anfibólio é calculada para 23-oxigênios, com $\mathrm{Fe}^{3+}$ cálculado segundo os procedimentos descritos por Spear (1980).

A temperatura pode ser obtida a partir do gráfico $X_{N a}{ }^{A} \times X_{A b}$ (p. 362, Spear, 1981), ou através das equações:

(1) $T(K)=(-7075+0,257 P) /\left(-6,86+1,987 \ln K_{\text {id }}\right)$

onde: $K_{i d}=X_{N a}{ }^{A} /\left(X_{D}{ }^{A} X_{A b}\right)$, válido quando $X_{A b}=0,75$

(2) $T(K)=(47000-0,24 P) /(44,27-3,974 \ln K)$

onde: $K=\left(X_{A n} / X_{A b}\right)\left(X_{N a}{ }^{M 4} / X_{C a}{ }^{M 4}\right)$, quando $X_{A b} \neq 0,75$

Uma consideração importante apresentada por Spear (1981) é que anfibólios em anfibolitos com quartzo equilibrados a pressões altas possuem maior ocupação da posição $A$ que aqueles cristalizados a baixas pressões e temperaturas equivalentes.

Para fins de testar a consintência entre os termômetros anfibólio-plagioclásio citados acima nas rochas estudadas no presente trabalho, fez-se o cálculo das temperaturas para pares minerais em equilibrio passiveis de terem suas temperaturas calculadas pelos três 
termômetros e arbitrou-se uma pressão de $5 \mathrm{Kbar}$. De modo geral observou-se que o termômetro de Blundy \& Holland (1990) apresenta temperaturas superestimadas (em relação aos demais e incoerentes com as associaçöes descritas) quando o Si é inferior a 7 pfu (amostras ST-S-6.A, ST-316.A e ST-338.C, localizadas na Amêndoa Macacos-Piaus; e amostras ST-S-6.A e ST-530, da Amêndoa Serra da Pinheira). (vide Tabela 15)

As diferenças encontradas nas temperaturas calculadas a partir dos termômetros de Spear (1981) e Holland \& Blundy (1994) estão dentro do erro analítico destes termômetros, que é da ordem de $50^{\circ} \mathrm{C}$.

\section{C) Geotermômetro-Geobarômetro Plagioclásio-Hornblenda:}

Plyusnina (1982) propõe um geotemômetro-geobarômetro com base em dados experimentais onde a reaçăo: hornblenda + zoesita (epidoto) $+\mathrm{H} 2 \mathrm{O}+\mathrm{CO} 2$ = plagioclásio + clorita + carbonato de cálcio + quartzo, que foi estudada sob condiçóes hidrotermais. A transição contínua da tremolita (actinolita) para anfibólios cálcicos, observada ao longo de uma curva de equilíbrio, permitiu ao autor demonstrar que a série dos anfibólios cálcicos se comporta como uma solução sólida completa. A dependência do alumínio em anfibólio-Ca coexistente com o plagioclásio, em função da temperatura e da pressão, foi determinada para temperaturas variando entre $450^{\circ}$ e $500^{\circ} \mathrm{C}$ e pressões entre 2 e 8 kbars e usada para construir o geotemobarômetro experimental ora em evidência. Este pode ser aplicado em metabasitos e xistos máficos do fácies albita-epidoto-anfibolito e anfibolito, incluindo assembléias com zoisita ou epidoto, e é eficaz, para temperaturas baixas, pressões acima de 4 kbars e sistemas sem ferro.

O experimento demonstrou uma significante variação do $\mathrm{Al} 2 \mathrm{O} 3$ no anfibólio- $\mathrm{Ca}$ em função da temperatura e da pressão, e uma variação da razão $\mathrm{Ca} / \mathrm{Ca}+\mathrm{Na}$ no plagioclásio em função da temperatura. A partir destes dados o autor construiu o gráfico $\mathrm{X}_{\mathrm{Na}}^{\text {plag }} \times \mathrm{Al}^{\text {anf }}$.

O erro padrão é de 1 kbar e de $15^{\circ} \mathrm{C}$, e as restrições impostas para a aplicação deste geotemobarômetro são: presença de zoesita ou epidoto; o Ca pfu deve ser superior a 1,5 e o Na pfu inferior a 1,0 no anfibólio, ausência de clinopiroxênio; e ainda, que a hornblenda e o plagioclásio devem ser sin-genéticos.

O geotermôbarômetro de Plyusnina mostrou-se, apesar de pouco preciso (é uma estimativa gráfica), uma boa correspondência, tanto para com as temperaturas, como para com as pressões obtidas utilizando-se outros termômetros e barômetros. Cabe resaltar entretanto, que nas análises de anfibólios onde Al pfu é inferior a 1,0 as pressões aferidas 
foram subestimadas, quando comparadas àquelas obtidas por outros métodos e mostraram-se incompativeis com as associações minerais descritas (Tabela 15).

\section{D) Geobarômetros Granada-Anfibólio-Plagioclásio:}

Kohn \& Spear (1989) propõem quatro geobarômetros empíricos com base na associação granada + hornblenda + plagioclásio + quartzo, aplicáveis em granada-anfibolitos e hornblenda-granulitos, metamorfisados em temperaturas que variam de $520^{\circ}$ a $800^{\circ} \mathrm{C}$ e pressões entre 3,5 a $14 \mathrm{kbar}$. No cálculo da fórmula estrutural dos anfibólios, utilizam o $\mathrm{Fe}^{3+}$ recalculado como mínimo.

O cálculo das atividades dos plagioclásios neste barômetro segue o modelo de atividades de Hodges \& Royden (1984, in Kohn \& Spear, 1989) e o cálculo das atividades da granada segue o modelo de Hodges \& Spear (1982).

Para o cálculo das atividades dos anfibólios, Kohn \& Spear (1989) propóem dois modelos distintos a partir da distribuição dos componentes químicos nos sítios de alocação da pargassita, Fe-pargassita, tremolita e Fe-tremolita. No modelo 1 assumem uma mistura independente em cada sítio de alocação do anfibólio. As desvantagens deste modelo são que a ocupação dos sítios variam com a quantidade de $\mathrm{Fe}^{3+}$ (geralmente, recalculado), as atividades calculadas para os membros minerais são suscetíveis a erros analíticos, e a partição Fe-Mg tem que ser conhecida. No modelo 2 os referidos autores assumem que um completo balanceamento dos sítios de locação dos cátions ocorre associado à variação da pargassita.

São quatro as fórmulas para os cálculos das pressões, aplicáveis, respectivamente, quando se utiliza o cálculo das atividades do anfibólio do modelo 1 e do modelo 2 :

Modelo 1:

$P_{\text {Mg }}$ (bars) $=\left(120593+T .\left(10,3+8,314 \ln K_{\text {eq1 }}\right) / 14,81\right.$

$P_{\mathrm{Fe}}$ (bars) $=\left(117993+\mathrm{T} .\left(-47,8+8,314 \ln \mathrm{K}_{\text {eq } 2}\right) / 11,29\right.$

Modelo 2:

$P_{M g}$ (bars) $=\left(44724+T .\left(51,9+8,314 \ln K_{\text {eq1 }}\right) / 9,19\right.$

$P_{\mathrm{Fe}}$ (bars) $=\left(-4948+T \cdot\left(81,8+8,314 \ln \mathrm{K}_{\mathrm{eq} 2}\right) / 9,52\right.$

onde: $K_{\mathrm{eq} 1}=\left(a_{\mathrm{gr}}{ }^{2} \mathrm{a}_{\mathrm{py}} a_{\mathrm{parg}}{ }^{3} \mathrm{a}_{\mathrm{qt}}{ }^{18}\right) /\left(\mathrm{a}_{\mathrm{An}}{ }^{6} \mathrm{a}_{\mathrm{Ab}}{ }^{3} \mathrm{a}_{\mathrm{tr}}{ }^{3}\right)$

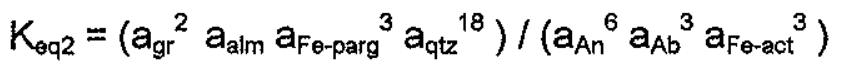

Além da associação mineral e das temperatura e pressões e já mencionadas, outras restrições para a aplicação destes geobarômetros são: o $X_{s p}$ na granada deve ser menor que 
0,2; $\circ \mathrm{X}_{\mathrm{An}}$ no plagioclásio deve ficar entre 0,15 e 0,6; e o anfibólio deve apresentar: $6,1=\mathrm{Si} \geq$ 6,$6 ; 0=\mathrm{Ti} \geq 0,275 ; 1,7=\mathrm{Fe} \geq 2,8 ; 1,5=\mathrm{Ca} \geq 1,9 ; 0=\mathrm{K} \geq 0,4 ; 2=\mathrm{Al} \geq 3,2 ; 0,975=\mathrm{Mg} \geq 2,7$ $; 0=\mathrm{Mn} \geq 0,05 ; 0,35=\mathrm{Na} \geq 0,6 ; 2,1=\mathrm{Ca}+\mathrm{Na}+\mathrm{K} \geq 2,75$. A precisão do barômetro (função da temperatura e da análise química do mineral) varia de 200 a 600 bars, para cada $50^{\circ} \mathrm{C}$, e a exatidão é de 5 kbars para cada $150^{\circ} \mathrm{C}$.

Kohn \& Spear (1990) revisam o barômetro proposto em 1989, propondo dois novos geobarômetros empiricos, com base nas equaçöes: (a) 6 anortita +3 tremolita $=2$ grossularita + piropo +3 tschermaquita +6 quartzo, e (b) 6 anortita +3 Fe-tremolita $=2$ grossularita + almandina +3 Fe-tschermaquita +18 quartzo.

As equações de equilíbrio propostas neste barômetro são:

$$
\begin{aligned}
& P_{\text {Mg }}(\text { bras })=\left(79507+T\left(29,14+8,3144 \ln K_{\text {eq } 1}\right)\right) / 10,988 \\
& P_{\mathrm{Fe}}(\text { bras })=\left(35327+T\left(56,09+8,3144 \ln K_{\text {eq2 }}\right)\right) / 11,906 \\
& \text { onde } K_{\text {oq } 1}=\left(a_{g r}{ }^{2} a_{p y} a_{t s c h}{ }^{3} a_{q t z}{ }^{6}\right) /\left(a_{A n}{ }^{6} a_{t r}{ }^{3}\right) \\
& K_{\text {eq2 }}=\left(a_{g r}{ }^{2} a_{a l m} a_{\mathrm{Fe}-\mathrm{tsch}}{ }^{3} a_{\mathrm{qtz}}{ }^{6}\right) /\left(a_{\mathrm{An}}{ }^{6} a_{\mathrm{F \theta}-\mathrm{act}}{ }^{3}\right)
\end{aligned}
$$

As atividades da granada e do plagioclásio são calculadas a partir do mesmos modelos utilizados no trabalho de Kohn \& Spear (1989), porém para o calculo das atividades do anfibólio os autores apresentam as seguintes fórmulas:

$$
\begin{aligned}
& a_{\mathrm{tsch}}=9,481481\left(X_{A l}{ }^{\top 1}\right)\left(X_{S i}{ }^{T 1}\right)^{3} \cdot(\mathrm{Mg} / \mathrm{Mg}+\mathrm{Fe}) \\
& a_{t r}=\left(X_{S i}{ }^{\top 1}\right)^{4} \cdot(M g / M g+F e)^{2} \\
& a_{\mathrm{Fe-tsch}}=9,481481\left(X_{A \mid}^{\top 1}\right)\left(X_{S !}^{T 1}\right)^{3} .(\mathrm{Fe} / \mathrm{Mg}+\mathrm{Fe}) \\
& a_{\mathrm{Fe}-\mathrm{act}}=\left(\mathrm{X}_{\mathrm{Si}}^{\mathrm{T} 1}\right)^{4} \cdot(\mathrm{Fe} / \mathrm{Mg}+\mathrm{Fe})^{2}
\end{aligned}
$$

As aproximações utilizadas ignoram a não-idealidade dos anfibólios, as capacidades caloríficas e as mudanças de volume com a pressão e a temperatura, mesmo assim os coeficientes de correlação são elevados e o barômetro apresenta um boa consistência, sendo pouco sensiveis às temperaturas estimadas e a erros analíticos quando aplicados dentro das especificações proposta pelos autores, que, resumidamente, são: rochas com a associação granada + hornblenda + plagioclásio + quartzo, ocorrentes sob pressões entre 2,5 e 13 kbars e temperaturas entre $500^{\circ} \mathrm{C}$ e $800^{\circ} \mathrm{C}$; os anfibólios devem ser calculado para 23-oxigênio, com - $\mathrm{Fe}^{3+}$ recalculado como ferro mínimo e apresentar: teores de $\mathrm{Al}$ estar entre 1,9 e 3,75; $\mathrm{Ti}$ maior que 0,275; o Ca pfu ser maior que 1,5; o Na pfu entre 0,3 e 0,6; ○ K maior que 0,4; e o $\mathrm{Fe} / \mathrm{Fe}+\mathrm{Mg}$ entre 0,4 e 0,6 . A granada deve ser calculada para 12-oxigênios e ter o $\mathrm{Fe}^{3+}$ recalculado utilizando as relações estiquiométricas $e$ as restrições do balanço de cargas, e $X_{s p}$ 
$\leq 0,2$. O plagioclásio, calculado para 8-oxigênios deve ter Ca pfu entre 0,15 e 0,7 Dentro destas especificações o erro analítico fica na ordem de 0,5 kbars, segundo Kohn \& Spear (1990).

Comparando-se dados de pressão obtidos pelo barômetro Kohn \& Spear (1989), a partir de suas quatro equações e aquelas obtidas Kohn \& Spear (1990), utilizando-se as duas equações propostas, observa-se que as médias aritiméticas das pressōes obtidas para cada par metamórfico estudado são compativeis entre si, estando as diferenças entre elas dentro do desvio padrão das mesmas (Tabela 15).

\section{E) Geotermômetros Granada-Biotita:}

O termômetro granada-biotita é bastante difundido na literatura. Perchuck (1967 e 1970 , in Ferry \& Spear, 1978) foi o primeiro a calibrar este termômetro empiricamente e Ferry \& Spear (1978) foram os primeiros a estuda-los experimentalmente.

Ferry \& Spear (1978) propõem um termômetro experimental feito com base na troca catiônica entre o Fe-Mg na reação: almandina + flogopita = piropo + anita. Para que não sejam necessárias correções, em função da presença, principalmente, do alumínio na biotita e do cálcio e manganês na granada, algumas restrições são impostas para o uso deste termômetro, a saber: na granada $\circ(\mathrm{Ca}+\mathrm{Mn}) /(\mathrm{Ca}+\mathrm{Mn}+\mathrm{Mg}+\mathrm{Fe}) \leq 0,2$, na biotita $\left.\circ(\mathrm{Al})^{\mathrm{Vl}}+\mathrm{Ti}\right) /\left(\mathrm{Al} l^{\mathrm{VI}}+\mathrm{Ti}+\mathrm{Fe}\right.$ $+\mathrm{Mg}) \leq 0,15$, e idealmente, o Fe/(Fe+Mg) deve estar entre 0,8 e 1,0, em ambos os minerais. $\mathrm{A}$ fórmula mineral da biotita é calculada com base anidra em 11-oxigênios e da granada em 12oxigênios, em ambas todo ferro é tratado como $\mathrm{Fe}^{2+}$.

O termômetro é muito consistente para pressões em torno de 2 kbar e temperaturas entre $550^{\circ} \mathrm{C}$ e $800^{\circ} \mathrm{C}$, apresentando erro analítico da ordem de $50^{\circ} \mathrm{C}$. É muito utilizado em rochas metapelíticas típicas, sendo a temperatura calculada pela fórmula:

$T(K)=(0,057 P+12454) /\left(4,662-5,961\right.$ in $\left.K_{D}\right)$

onde: $K_{D}=\left(X_{p y} \cdot X_{a n n}\right) /\left(X_{p h} \cdot X_{a l m}\right)$

Devido as restrições para o uso da termômetro de Ferry \& Spear (1978), alguns dos pares granada-biotita selecionados no presente trabalho não puderam ser utilizados e por isso procurou-se aplicar outros termômetros granada-biotita, e verificar a consistência entre estes.

Lavrent'eva \& Perchuck (1981) calibraram experimentalmente o termômetro granadabiotita, para temperaturas variando de $575^{\circ}$ a $950^{\circ} \mathrm{C}$ e pressões de $6 \mathrm{kbar}$, assumindo uma precisão de $7^{\circ}-27^{\circ} \mathrm{C}$. A fórmula estrutural da granada é feita com base em 12-oxigênios e da 
biotita, com base anidra para 11-oxigênios, com todo ferro considerado como $\mathrm{Fe}^{2+}$. A temperatura é obtida pela fórmula:

$T(K)=(3947,1+0,0126 P) /\left(\ln K_{D}+2,868\right)$

onde: $K_{D}=\left(X_{M g} / 1-X_{M g}\right)^{\text {biot }} \cdot\left(1-X_{M g} / X_{M g}\right)^{g r}$

Aranovich et al (1988) definem um termômetro empírico levando em consideração a não idealidade da solução sólida granada-biotita. O cálculo da temperatura é feito utilizando-se a fórmula:

$T(K)=\left(3873,1+2871 X_{C a}{ }^{g r}+0,0124 P-975 N_{A}{ }^{\text {biot }}\right) /\left(\ln K_{D}+2,609+1,449 X_{C a}{ }^{g r}+0,287\right.$ $N_{A l}^{\text {biot }}+0,503 X_{F}^{\text {biot }}$

onde: $K_{D}=\left(X_{M g} / 1-X_{M g}\right)^{\text {biot }} \cdot\left(1-X_{M g} / X_{M g}\right)^{g r}$

Quando se compara as temperaturas obtidas pelos três termômetros granada-biotita cima citados observa-se que de modo geral as temperaturas calculadas pelo termômetro Ferry \& Spear (1978) são intermediárias entre as obtidas pelo termômetro Aranovich et al (1988) e aquelas calculadas pelo método de Lavrent'eva \& Perchuck (1981), que apresentam, respectivamente, valores inferiores e superiores às de Ferry \& Spear (1978). As diferenças nas temperaturas calculadas pelos três métodos é da mesma ordem de grandeza do erro analítico de termômetro de Ferry \& Spear (1978) considerado na literatura como o mais consistente pelo fato de ser experimental.

\section{F) Geobarômetro Granada-Biotita-Muscovita-Plagioclásio:}

Hoisch (1990) propõe a calibração empírica da pressão com base na associação granada-biotita-muscovita-plagioclásio-quartzo, através de seis barômetros calculados em associação com a calibração da temperatura. As equações envolvidas na calibração são:

(1) $1 / 3$ piropo $+2 / 3$ grossularita + eastonita +2 quartzo $=2$ anortita + flogopita

(2) $1 / 3$ almandina $+2 / 3$ grossularita + siderofilita +2 quartzo $=2$ anortita + annita

(3) $1 / 3$ piropo $+2 / 3$ grossularita + muscovita +2 quartzo $=2$ anortita + MgAl-celadonita

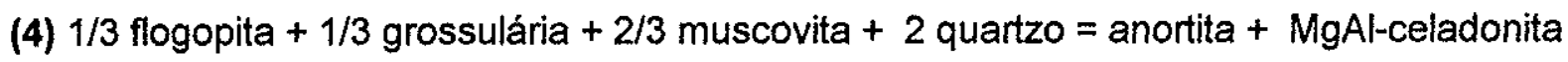

(5) piropo + grossulária + muscovita $=3$ anortita + annita

(6) almandina + grossulária + muscovita $=3$ anortita + annita

As micas são normalizadas para 11-oxigênios anidros sendo todo ferro considerado como $\mathrm{Fe}^{2+}$. As granadas são normalizadas para 12-oxigênios sendo o $\mathrm{Fe}^{3+}$ recalculado com base na restrição do balanço de cargas determinado para 8 cátions. O modelo de atividades 
das granadas segue o de Hodges \& Spear (1982). O plagioclásio é recalculado para 8oxigênios e o calculo de suas atividades segue o modelo de Newton et al (1980, in Hoisch, 1990).

Restrições ao uso deste barômetro, além da ocorrência da associação mineral, dizem respeito a composiçäo das micas, que devem ter: $0,00851 \leq X_{M_{g}}{ }^{\text {musc }} \geq 0,04330 ; 0,319 \leq X_{M g}{ }^{\text {biot }} \geq$ 0,$417 ; 0,339 \leq X_{\mathrm{Fe}}^{\text {biot }} \geq 0,443 ; 0,0894 \leq X_{A l}^{\text {biot }} \geq 0,1700 ;$ e, $0,024 \leq X_{T_{i}}^{\text {biot }} \geq 0,0732$.

As expressões geobarométricas calibradas são:

$P$ (bars) $=\left(31830,6+79,0281 \mathrm{~T}-8,3144 \mathrm{~T}\right.$ In $\mathrm{K}_{\mathrm{R} 1}-26968,7\left(\mathrm{X}_{\mathrm{Al}}^{\text {biot }}-\mathrm{X}_{\mathrm{Mg}}^{\text {biot }}\right)+32604,5 \mathrm{X}_{\mathrm{F \theta}}^{\text {biot }}+$ $\left.42855,4 \mathrm{X}_{\mathrm{Ti}}^{\text {biot }}\right) / 3,8145-2 / 3 \Delta \mathrm{V}_{\mathrm{gr}}$

$P$ (bars) $=\left(-46707,2+85,5824 T-8,3144 T \ln K_{R 2}-30960,2\left(X_{A 1}^{\text {biot }}-X_{F e}{ }^{\text {biot }}\right)+24289,6 X_{M g}^{\text {biot }}+\right.$ $\left.37265,6 \mathrm{X}_{\mathrm{Ti}}^{\text {biot }}\right) / 3,8986-2 / 3 \Delta \mathrm{V}_{\mathrm{gr}}$

$P$ (bars $)=\left(-20681,4+69,8341 T-8,3144 T\right.$ In $K_{R 3}-185443\left\{\left(X_{M g}^{\text {musc }} \cdot\left(X_{M g}^{\text {musc }}-2\right) / 4,1740-\right.\right.$ $2 / 3 \Delta \mathrm{V}_{\mathrm{gr}}$

$P$ (bars) $=\left(-21664,0+33,7500 T-8,3144 T \ln K_{R 4}-172479\left\{\left(X_{M g}^{\text {musc }} \cdot\left(X_{M g}^{\text {musc }}-2\right) / 2,19415-\right.\right.\right.$ $2 / 3 \Delta \mathrm{V}_{\mathrm{gr}}$

$P$ (bars) $=\left(3546,01+121,347 T-8,3144 T \ln K_{R 5}\right) / 6,37161-\Delta V_{g r}$

$P($ bars $)=\left(-55530,4+140,635 T-8,3144 T \ln K_{R 6}\right) / 6,59940-\Delta V_{g r}$

onde: $K_{R 1}=X_{f l o g} \cdot\left(a_{a n}\right)^{2} /\left(a_{p y}\right)^{1 / 3} \cdot\left(a_{g r}\right)^{2 / 3} X_{\text {eas }}$

$$
\begin{aligned}
& K_{R 2}=X_{\text {ann }} \cdot\left(a_{a n}\right)^{2} /\left(a_{a l m}\right)^{1 / 3} \cdot\left(a_{g r}\right)^{2 / 3} X_{\text {sid }} \\
& K_{R 3}=X_{c e l} \cdot\left(a_{a n}\right)^{2} /\left(a_{p y}\right)^{1 / 3} \cdot\left(a_{g r}\right)^{2 / 3} X_{\text {musc }} \\
& K_{R 4}=X_{c e l} \cdot a_{a n} /\left(X_{\text {flog }}\right)^{1 / 3} \cdot\left(a_{g r}\right)^{1 / 3}\left(X_{\text {musc }}\right)^{2 / 3} \\
& K_{R 5}=X_{\text {fiog }} \cdot\left(a_{a n}\right)^{3} / a_{p y} \cdot a_{g r} X_{\text {musc }} \\
& K_{R 6}=X_{a n n} \cdot\left(a_{a n}\right)^{3} / a_{a l m} \cdot a_{g r} X_{\text {musc }}
\end{aligned}
$$

\section{G) Geobarômetro/Geotermômetro Granada-Biotita-Muscovita-Plagioclásio:}

Ghent \& Stout (1981) descrevem um termômetro empírico para rochas metassedimentares da zonas da granada até a zona da sillimanita, envolvendo mudanças de coordenação do alumínio octaedral para tetraedral e Mg-Fe da coordenação oito para seis, dependentes da pressão, com base nas equações:
(a) piropo + grossularita + muscovita $=3$ anortita + flogopita
(b) almandina + grossularita + muscovita $=3$ anortita + annita
(b) almandina + flogopita $=$ piropo + annita 
Como as equações são calibradas a partir de dos geotermómetros granada-biotita e granada-biotita-plagioclásio-quartzo-Al2SiO5, acumula erros (para cada $50^{\circ} \mathrm{C}$ de erro gera-se $1 \mathrm{Kbar}$ de erro para a pressäo), o erro mínimo admitido é de 800 bars, apesar disso trata-se de um barômetro bom para monitorar a pressão de rochas ricas em alumínio.

A fórmula estrutural das micas é calculada com base em 11-oxigênios anidros, com todo o ferro considerado como $\mathrm{Fe}^{2+}$, onde $\left(X_{\mathrm{ANI}}+\mathrm{X}_{\mathrm{Ti}}\right)$ nas biotitas pode variar entre 0,14 e 0,21 pfu. A granada é calculada para 12-oxigênios com todo ferro considerado como $\mathrm{Fe}^{2+}$, e deve ter $\left(X_{c a}+X_{M n}\right)$ entre 0,21 e 0,23 . O plagioclásio calculado para 8-oxigênios, deve ter $X_{A n}$ entre 0,2 e $0,8 \mathrm{pfu}$.

As equações aplicadas são:

$P$ (bars) $=\left(-1,987 \mathrm{~T}\right.$ LnK $\left._{1}+16,675 \mathrm{~T}+8888,4\right) / 1,738$

$P$ (bars) $=\left(-4124,4+22,061 \mathrm{~T}-1,987 \mathrm{~T} \mathrm{LnK}_{2}\right) / 1,802$

onde: $K_{1}=\left(X_{\text {an }}\right)^{3} \cdot\left(X_{\text {flog }}\right)^{3} /\left[X_{K}^{\text {musc }} \cdot\left(X_{A N 1}{ }^{\text {musc }}\right)^{2}\right] \cdot\left(X_{p y}\right)^{3} \cdot\left(X_{g r}\right)^{3}$

$K_{2}=\left(X_{\text {ann }}\right)^{3} \cdot\left(X_{\text {ann }}\right)^{3} /\left[X_{K}^{\text {musc }} \cdot\left(X_{A I V I}^{\text {musc }}\right)^{2}\right] \cdot\left(X_{A i}\right)^{3} \cdot\left(X_{\text {gr }}\right)^{3}$

\section{H) Geobarômetro Granada-Plagioclásio-Quartzo-Al2SiO5:}

Hodges \& Spear (1982) observam que a não idealidade da mistura de piropogrossularita é na partição entre os quatro componentes da granada, e que o coeficiente de atividade da anortita no plagioclásio é aproximadamente 2 no ponto tríplice. A partir de tais observações, os autores propõem a seguinte equação para o cálculo da pressão em rochas com sillimanita:

$P($ bars $)=[-11669,01+(30,97+5,961 \operatorname{Ln} K) T] / 1,29$

onde: $\mathrm{K}=\mathrm{X}_{\mathrm{Ca}}{ }^{\mathrm{gr}} / \mathrm{X}_{\mathrm{ca}}{ }^{\text {plag }}$

As restrições impostas em cada um dos três barômetros acima citados, aplicáveis para rochas metassedimentares, näo possibilitou a comparação entre eles. Entretanto, observa-se que as pressões calculadas (Tabela 15), em torno de $4 \mathrm{Kbar}$, para rochas da Sequência Piancó (Complexo Cachoeirinha), através do barômetro de Hoish (1990), na amostra Pl-4, e Hodges \& Spear (1982), na amostra PI-16.2, mostraram-se coerentes com as associaçōes minerais descritas, onde andalusita e/ou cordierita podem estar presentes. Por outro lado as pressões obtidas pelo barômetro de Ghent \& Stout (1981), nas amostras ST-200.2 e ST-314, localizadas na Amêndoa Macacos-Piaus (Complexo Riacho Gravatá), são ligeiramente inferiores àquelas calculadas para rochas metabásicas da mesma área (quando se compara os valores médios para cada "par" metamórfico, sem no entanto consideramos os desvios padrões). 


\section{IV.4 CONSIDERAÇÕES}

Os dados de temperatura e pressão calculados pelos termômetros e barômetros discutidos anteriormente estão listados na Tabela 15. Os valores expressos são as médias aritméticas dos valores obtidos através do uso de mais de um par metamórfico ou, em alguns casos pela obtenção dos resultados por mais de uma fórmula (como nos casos do termômetro de Holland \& Blundy, 1994 e do barômetro de Kohn \& Spear, 1990) com seus respectivos desvios padrões. A temperatura elou pressão obtida para os centros dos minerais são interpretadas como a temperatura e/ou pressão mínimas para o pico do metamorfismo enquanto aquelas obtidas para a borda são interpretadas como as condições T/P do final deste evento. Dados de retrometamorfismo foram obtidos em metapelitos através de cálculos de temperatura e/ou pressão envolvendo borda de granadas e porfiroblástos tardios de biotita, e em anfibolitos a partir de texturas de substituição.

No gráfico T X P (Fig. 17) estão plotadas os dados destacados em negrito na Tabela 15, selecionados por estarem em concordância com as paragêneses descritas em cada amostra e por terem sido calculados por termômetros e/ou barômetros mais utilizados na literatura. Alguns dos dados selecionados foram descartados do gráfico T/P por terem seus valores de bordo e centro praticamente iguais, em função dos desvios padrões ou do erro analítico admitido.

A análise dos dados da Sequência Piancó (Complexo Cachoeirinha) indica que as condições minimas para o pico do metamorfismo ocorrido durante a segunda fase de deformação, calculada em metassedimentos (amostras $\mathrm{Pl}-4$ e $\mathrm{Pl}-16.3$ ), foi de cerca de $700^{\circ} \mathrm{C}$ e 4,5 kbar. Um retrometamorfismo, ocorrido durante a terceira fase deformação, se deu há $430^{\circ} \mathrm{C}$ e pressão de $4 \mathrm{kbar}$. Estes dados sugerem uma trajetória T/P no sentido horário para estas rochas e fornecem um paleogradiente geotérmico, para o pico do metamorfismo, de cerca da $42^{\circ} \mathrm{C} / \mathrm{Km}$.

Para os metassedimentos da Sequência Santana dos Garrotes (Complexo Cachoeirinha) não foi possivel calcular a pressão, mas para uma pressão arbitrada de 5 kbar, a temperatura calculada para o centro dos minerais foi de $540^{\circ} \mathrm{C}$ e para a borda em torno de $500^{\circ} \mathrm{C}$ (em amostras localizadas na porção mais a norte desta sequência). As amostras mais a sul forneceram valores de $480^{\circ} \mathrm{C}$.

Nas rochas do Complexo Riacho Gravatá, Amêndoa Macacos-Piaus, as temperaturas tanto para o centro quanto para a borda dos minerais, calibradas em metassedimentos (ST- 
200.2, ST-203.1, ST-205 e ST-314) encontram-se entre $450^{\circ}-500^{\circ} \mathrm{C}$ e as pressões entre 7,5 8,0 kbar. As temperaturas para as recristalizações retrometamórficas estão estimadas a $480^{\circ}$ $\mathrm{C}$ e $450^{\circ} \mathrm{C}$, calculadas para pressão arbitrada de 8 kbar. Nos anfibolitos (ST-305.E, ST312.E, ST-206.2, ST-316,A, ST-6.A, ST-322.D, ST-338.C e ST-338.C) as temperaturas mínimas para o pico ficam entre $450^{\circ} \mathrm{C}$ e $660^{\circ} \mathrm{C}$ e as pressões entre $8,0-10,0 \mathrm{kbar}$. As temperaturas calculadas para a borda dos pares minerais nos anfibolitos são semelhantes $\left(460^{\circ} \mathrm{C}\right.$ e $\left.650^{\circ} \mathrm{C}\right)$ apesar das pressões mais baixas $(7,5$ - 8,0 kbar). As fases minerais das texturas retrometamórficas, calculadas arbitrariamente para pressőes de $8,0 \mathrm{kbar}$, encontram-se entre $450^{\circ} \mathrm{C}$ e $480^{\circ} \mathrm{C}$. A análise em separado dos pares metamórficos utilizados nestas calibrações, sugerem um caminho T/P no sentido anti-horário e indicam um paleogradiente geotérmico médio de $16^{\circ} \mathrm{C} / \mathrm{Km}$.

Na Amêndoa Serra da Pinheira (Complexo Riacho Gravatá) para a amostra ST-530, localizada na porção sudeste, a temperatura mínima para o metamorfismo é de $560^{\circ} \mathrm{C}$ e a pressão de 4,0 - 5,0 kbar, enquanto que para a amostra ST-AC-35.2, a norte da cidade de Manaíra, a temperatura calculada para uma pressão arbitrada de $5,0 \mathrm{kbar}$ é de $470^{\circ} \mathrm{C}$ (temperatura mínima para 0 pico do metamorfismo). As associações minerais retrometamórficas indicam uma temperatura de $470^{\circ} \mathrm{C}$. O paleogradiente geotérmico para o pico do metamorfismo neste domínio é de cerca de $25^{\circ} \mathrm{C} / \mathrm{Km}$.

Para a amostra ST-475-A, localizada a leste do Complexo Serra Talhada, calculou-se uma temperatura de $610^{\circ} \mathrm{C}$ e uma pressão de $9,0 \mathrm{kbar}$, para o auge do metamorfismo. As fases minerais relacionadas à textura de substituição (quelifítica) indicam uma temperatura de $570^{\circ} \mathrm{C}$, para uma pressão arbitrada de $9,0 \mathrm{kbar}$. Tais condições metamórficas são compatíveis com um paleogradiente geotérmico de $17^{\circ} \mathrm{C} / \mathrm{Km}$, similar ao encontrado para as rochas do Complexo Riacho Gravatá, Amêndoa Macacos-Piaus.

Nos Xistos Sertânia a temperatura mínima para o pico do metamorfismo atingiu $660^{\circ} \mathrm{C}$ a uma pressão de 4,0 kbar. Essa temperatura tende a crescer para $670^{\circ} \mathrm{C}$ quando calculada nos pares biotita/borda de granada em equilibrio, e atinge $700^{\circ} \mathrm{C}$ quando calculada a partir das associações com biotitas pós-foliação principal S2. Este aumento na temperatura, condizente com a microtextura observada, onde a granada sobrecresce a foliação principal, pode estar associado ao domeamento e ascensão do Complexo Serra Talhada e indica um posicionamento crustal distinto para estas rochas em relação àquelas do Complexo Riacho Gravatá. O paleogradiente geotérmico estimado para o pico do metamorfismo nestes xistos é de $42^{\circ} \mathrm{C} / \mathrm{Km}$. 


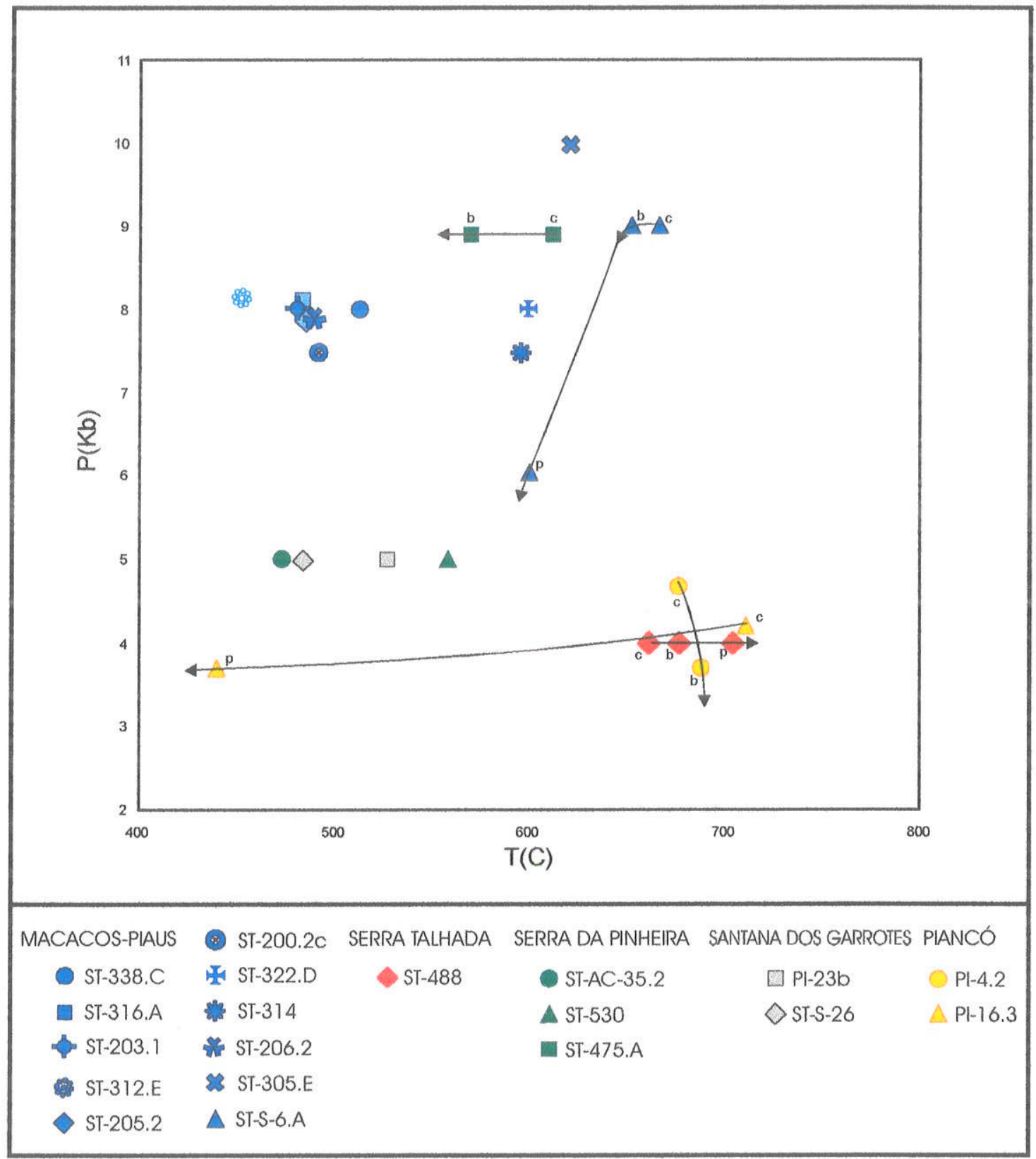

Fig. 17) Gráfico T x P evidenciando o contraste metamórfico entre os distintos terrenos tectonoestratigráficos estudados. 
Condições metamórficas contrastantes foram evidenciadas neste estudo. Elas apontam para distintos ambientes tectônicos, sugerem distintos regimes deformacionais e um grande transporte lâminas crustais quando da extrusão e justaposição dos distintos terrenos tectonoestratigráficos.

O baixo gradiente térmico expresso pelas rochas do Complexo Riacho Gravatá na Amêndoa Macacos-Piaus aproxima-se de valores compativeis com o metamorfismo em zonas de subducção (Spear, 1995). Por outro lado a amêndoa antiformal-Piancó e também os Xistos Sertânia estiveram submetidos a condiçōes metamórficas que admitem paleogeotermas comprimidas e paleogradiente térmico abrupto, típicos de crostas adelgaçadas e sob alto fluxo térmico, o que permite, regionalmente, a ascensão da temperatura à níveis crustais mais altos. Tais gradientes térmicos foram modelados em bacias extensionais (McKenzie, 1978; Royden et al, 1980).

As registros comparáveis a ambientes de subducção, preservados na Amêndoa Macacos-Piaus devem estar ligadas a um processo de underthrust, de crosta continental relativamente fria, dirigido para noroeste à profundidades de $30 \mathrm{~km}$. Este processo, destacado pela extrusão subsequente em sistema de cavalgamento para SE, poderia estar relacionado com o limite setentrional do terreno tectono-estratigráfico Pajeú-Paraíba sob extensão litosférica NW-SE.

A Amêndoa antiformal-Piancó parece ter se submetido a um regime deformacional extensional, W.NW-E.SE, controlado pela implantação precoce e de alta temperatura do sistema transcorrente Patos-Boqueirão dos Cochos, controlada por uma compressão próxima a NS. 


\section{GEOLOGIA ESTRUTURAL}

A estruturação da Faixa Piancó-Alto Brígida está associada a um sistema de cisalhamento transcorrente que define diferentes dominios estruturais e afeta estruturas precoces responsáveis pela geraçăo da foliação principal $\mathrm{S2}$, desenvolvida durante o pico do metamorfismo. Este sistema de cisalhamento está inserido no Cinturão de Cisalhamento Patos-Floresta, de caráter dúctil-rúptil, responsável pela arquitetura final do Domínio Tectônico Rio Pajeú (Campos Neto et al, 1994a e b).

$\mathrm{Na}$ área do presente trabalho sete domínios estruturais, foram definidos e designados de: Piancó, Santana dos Garrotes, Serra Da Pinheira, Serra do Mocambo, Macacos-Piaus, Serra Talhada e Serra do Olho D'Água. Com exceção do domínio estrutural Serra do Olho D'Água, onde as estruturas foram correlacionadas a terceira fase de deformação, descreve-se para os demais domínios uma estruturação, ao menos na escala mesoscópica, relacionada a superposição de cinco fases de deformação.

\section{V.1 ORGANIZAÇÃO E CRONOLOGIA DAS ESTRUTURAS}

A primeira fase de deformação (F1) é representada, na área do presente trabalho, por uma foliação S1, visível apenas a nivel de microestrutura. Em seções delgadas de rochas metassedimentares e metavulcânicas, observa-se que a foliação principal, mesoscopicamente descrita como clivagem diferenciada, corresponde a uma clivagem de crenulação transposta, definida pela presença local de charneiras reliquiares. Estas charneiras de microdobras estão melhor preservadas nos níveis micáceos, onde as micas crenuladas, ou recristalizadas em arcos poligonais, denotam a existência de uma foliaçăo anterior $S 1$ (Fotos 17 e 21). A foliação S1 também pode ser identificada como uma foliação interna $\left(S_{i}\right)$ em porfiroblástos de granadas, estaurolitas e cordieritas, crescidas durante a segunda fase de deformação. Neste caso está definida por inclusões orientadas, principalmente de minerais opacos e de quartzo. (Fotos 16, 17, 21 e 22)

A segunda fase de deformação (F2) é representada pela foliação principal, geralmente desenvolvida a partir de uma clivagem de crenulação, que evolui à transposição generalizada 
da foliação S1. Ela é definida pela orientação paralela de minerais planares elou tabulares e desenvolve um bandamento composicional tectônico (bandamento diferenciado). Durante esta fase ocorreu o máximo de recristalização metamórfica, evidenciada pelo crescimento de minerais indices do metamorfismo em metapelitos (granada, estaurolita, andalusita e cordierita). Em algumas amostras fica evidente o caráter contínuo da deformação no desenvolvimento das foliações $S 1$ e $S 2$. Seja através de inclusões orientadas $\left(S_{i}\right)$ em porfiroblástos de granadas, retas no centro e passando continuamente a crenuladas nas bordas, seja pela crenulação e transposição de $S 1$ externamente aos porfiroblástos. A foliação S2 desenvolveu-se preferencialmente como plano axial de dobras D2. As dobras D2 estão axialmente orientadas na direção NE-SW, são fechadas a isoclinais recumbentes e assimétricos. Localmente, a foliação $\mathrm{S} 2$, passa a um padrão anastomosado, definindo um arranjo do tipo S-C (Lister \& Snoke, 1984). Esta foliação $S-C_{(2)}$ grada para zonas miloníticas mais intensas, sub-horizontais, onde associam-se a dobras em bainhas.

Quatro tipos de lineações associadas a F2 são descritas: lineação mineral $\left(\mathrm{Lm}_{2}\right)$, definida pela orientação preferencial de minerais, tais como micas, anfibólios e aluminossilicatos; lineação de estiramento $\left(L_{2}\right)$, desenvolvida através do estiramento, acompanhado ou não pela recristalização, de grãos de quartzo, feldspatos, agregados quartzofeldspáticos, minerais opacos e, mais raramente, de anfibóbios; lineação de intercessão $\left(\mathrm{Li}_{2}\right)$ entre o par assimétrico S-C; e lineação de crenulação $\left(L_{C_{2}}\right)$, definida pelo ápice de charneiras de crenulações $D 2$, paralela aos eixos- $B$ de pequenas dobras. As duas primeiras lineações indicam a direção $X$ de dilatação positiva do elipsóide de deformação finita, encontram-se na direção de transporte por cisalhamento e são paralelas ao alongamento das dobras em bainha. A terceira lineação $\left(\mathrm{Li}_{2}\right)$ define uma direção aproximadamente perpendicular ao transporte por cisalhamento. A última lineação $\left(L C_{2}\right)$ define a orientação geométrica do eixo-B das dobras-D2.

As lineações $L m_{2}$ e $L e_{2}$ e as foliações $S-C_{(2)}$ definem os sistemas de cisalhamento dúctil sub-horizontal, que através dos critérios cinemáticos, amplamente difundidos na literatura, mostram transporte da placa superior para sudeste (Fig. 18 e anexos).

A terceira fase de deformação (F3) é representada por dobras delineadas pela foliaçãoS2 e observadas em todas as escalas e pela deformação principal ao longo das zonas de cisalhamento transcorrentes. As dobras D3 da foliação $S 2$ são assimétricas e tendem a isoclinais quase recumbentes, vergentes seja para SE (sul da Amêndoa Piancó, perfis E-E' e F-F', anexos 3 e 4), seja para NW (Amêndoa Macacos-Piaus, perfil A-A'), quando desenvolvidas no interior de pods transpressivos das zonas transcorrentes. Correspondem também a dobras normais, abertas, com direção axial NE-SW e que localmente admitem uma foliação plano-axial em leque e de forte mergulho $\left(50^{\circ}\right.$ a $\left.80^{\circ}\right)$. Esse dobramento D3 pode se 
intensificar, passando a dobras fechadas e de intensa transposição, cuja foliação S3 planoaxial grada a uma foliação milonítica paralela as zonas de cisalhamento transcorrentes.

As lineações associadas a F3, observadas são: lineação- $B$ de crenulação $\left(L C_{3}\right)$, a mais comum entre elas; lineação mineral $\left(\mathrm{Lm}_{3}\right)$, definida por porfiroblástos de biotita e/ou muscovita tardios; lineação de estiramento ( $\left(\mathrm{e}_{3}\right)$ descrita nas áreas onde ocorrem zonas de cisalhamento F3 e lineação de interseção $\left(\mathrm{Li}_{3}\right)$, seja de $\mathrm{S} 2 \mathrm{com} \mathrm{S3}$, seja de $\mathrm{S}-\mathrm{C}_{(3)}$, nos locais onde ocorre a transposição generalizada de $\$ 2$. As lineações minerais e as lineaçöes de estiramento são dominantemente sub-horizontais e contidas na foliação $\$ 3$ ou na foliação milonítica.

A nível microscópico são descritas crenulações que dobram assimetricamente a foliação principal $\$ 2$, com o desenvolvimento local de uma foliação S3, paralela ao plano axial, segundo o qual pode ocorrer crescimento de minerais metamórficos, tais como biotita e muscovita, e/ou a rotação de minerais preexistentes. Nas áreas de maior concentração de deformação, ou seja, nas zonas de cisalhamento $F 3$, a foliação $S 3$ pode ocorrer como uma clivagem espaçada, desenvolvida por processos de dissolução por pressão. As zonas de cisalhamento transcorrentes sin a tardi-F3 podem formar faixas de espessuras variáveis, subverticais, de orientação NE-SW, com inflecções para E-W.

As estruturas associadas a terceira fase de deformação são condizentes com a manutenção de um campo compressivo geral orientado NW-SE, característico do cinturão de cisalhamento dúctil-rúptil Patos-Floresta.

A quarta fase de deformação (F4) é representada, na área do presente trabalho por dobras e crenulações abertas (D4), locais, com o plano axial sub-horizontal e o eixo na direção NE-SW. As dobras D4 deformam o plano axial de dobras D3 e crenulam, localmente, a foliação milonítica gerada durante o cisalhamento D3 (Foto 24). Podem estar associadas a um plano sub-horizontal de cisalhamento rúptil-dúctil.

A quinta fase de deformaçăo (F5), também local, é ortogonal as demais fases descritas, e responsável por kink bands e por falhas e fraturas conjugadas. A nivel macroscópico descreve-se uma grande falha normal F5, que passa a noroeste da cidade de Manaíra, responsável pelo soerguimento do bloco sudeste em relação ao nordeste (Fig. 18 e anexos).

Estas duas últimas fases de deformação desenvolvidas em niveis crustais mais superiores, foram interpretadas por Campos Neto et al (1994a e b) como estruturas póscolisionais, da transição do regime compressivo para o regime distensivo e acompanhadas pelas numerosas intrusões de diques básicos (como o que ocorre a sul de Santana dos Garrotes) e de sienitos (comuns próximo ao batólito de Triunfo, sul da área do presente trabaho). 
A seguir são descritas e caracterizadas as estruturas das fases F2 e F3 em cada um dos domínios estruturais definidos no presente trabalho.

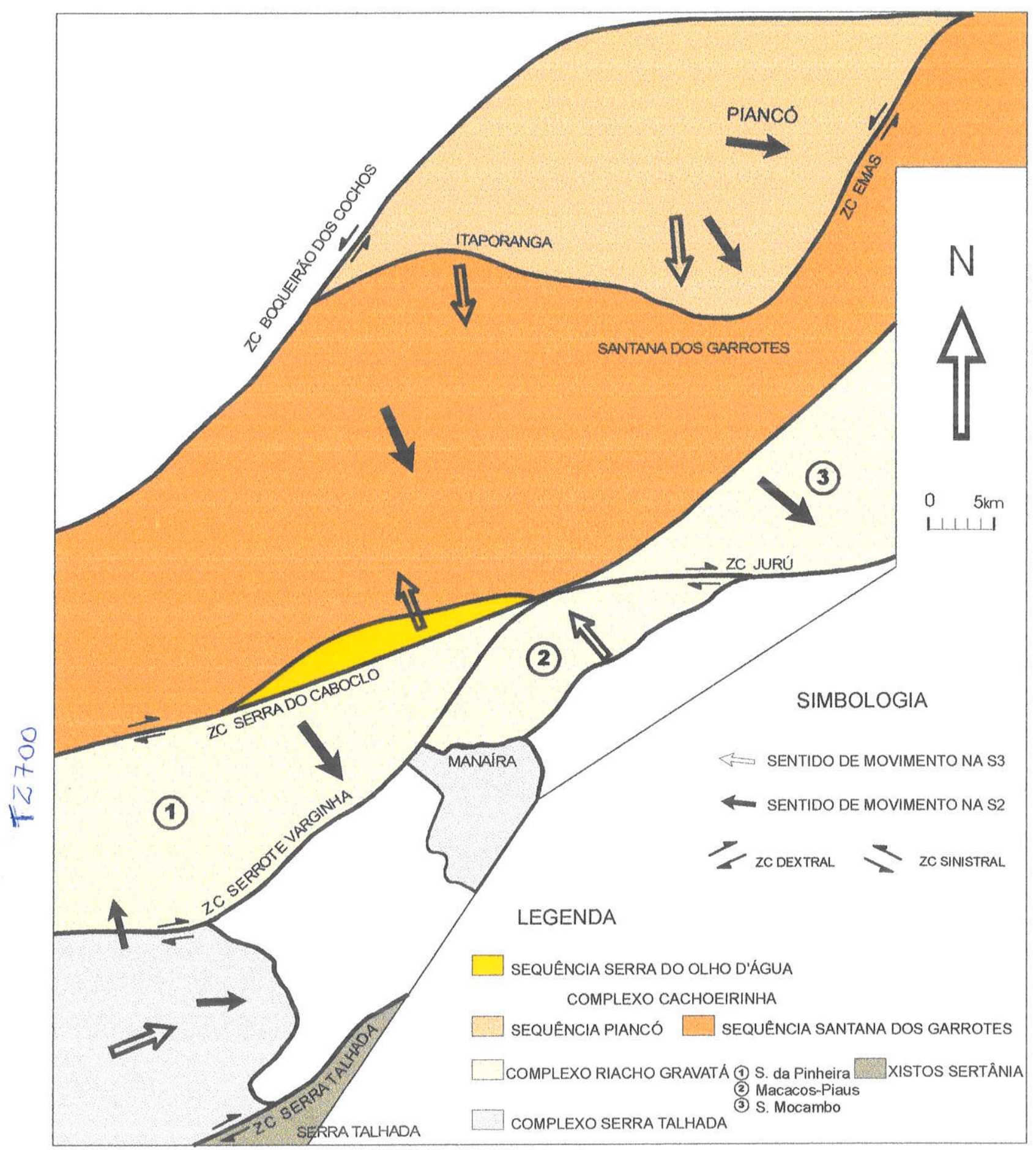

Fig 18) Mapa simplificado mostrando os domínios estruturais, seus limites e as direção de transporte observadas nas foliações S2 e S3. 

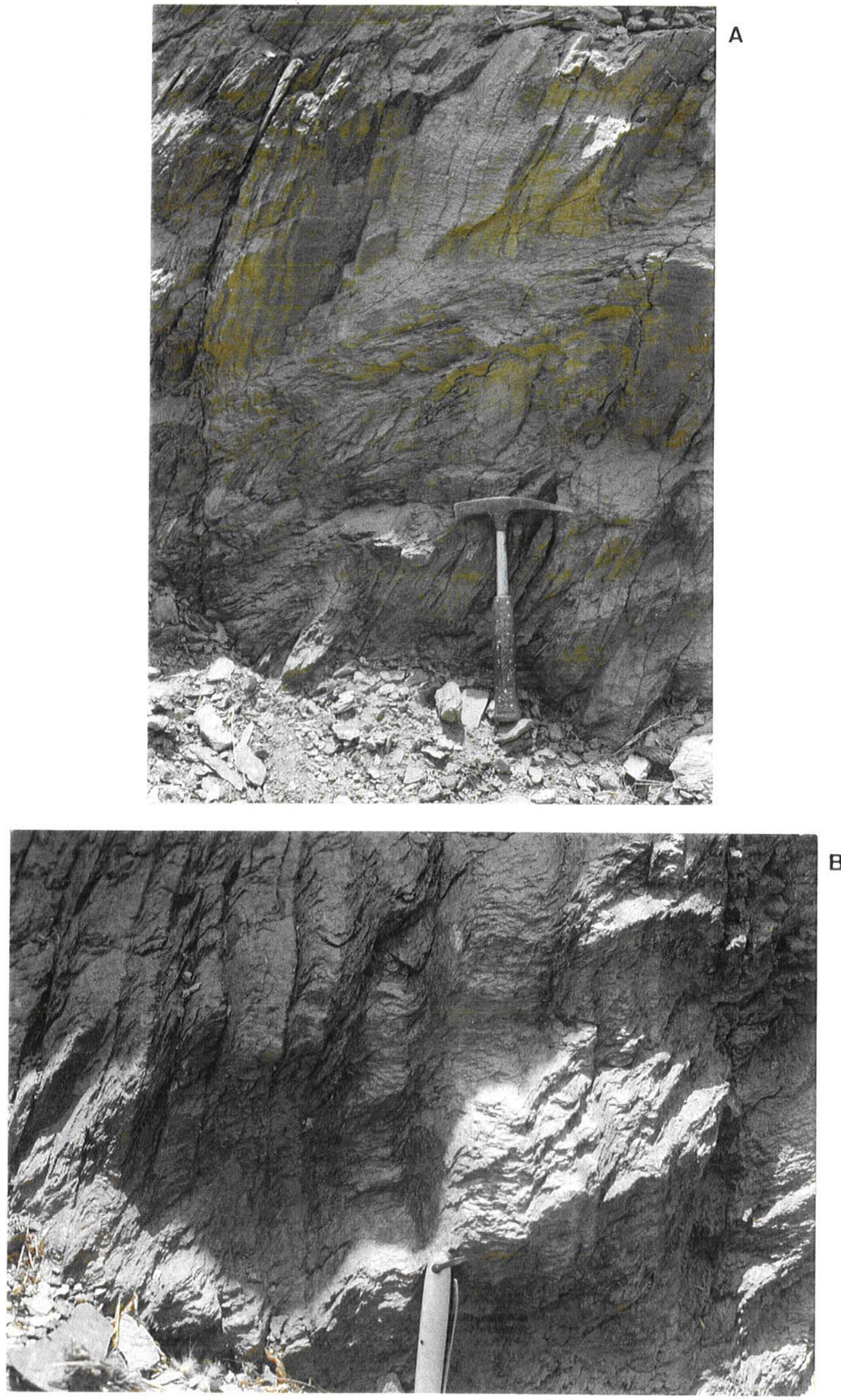

Foto 24) Xisto cinza fino da Sequência Santana dos Garrotes, localizado a oeste de Lagoa do Arroz. Observa-se (A) dobras D4 com plano axial sub-horizontal, deformando o bandamento diferenciado $S 3$, que crenula a foliação $S 2$, observada em detalhe na fotografia $(B)$ 


\section{V.2 DOMÍNIO ESTRUTURAL SERRA DA PINHEIRA - Sistema de cavalgamentos $\sin S 2$ para SE truncados por zonas de cisalhamentos transcorrentes $F 3$}

As estruturas macroscópicas descritas neste domínio estrutural, limitado a norte pela zona de cisalhamento dextral, de direção NE-SW, Serra do Caboclo e a sul pela Zona de Cisalhamento Serrote Varginha, dextral e com direção NE-SW, podem ser bem identificadas nos perfis Manaíra-Santana da Mangueira, Serra Talhada-Tabuleiro e LuandalÁgua Banca.

No Perfil Manaíra-Santana da Mangueira (perfil A-A', anexo 2) a estrutura mais notória associada a F2 é o sistema de cavalgamentos para SE. A foliação S2, via de regra apresenta, caimento suave a moderado para NW, tornando-se mais ingreme próximo a zonas de cisalhamento F3. Localmente, a foliação S2 possui uma textura protomilonítica e apresenta estruturas do tipo S-C (Foto 25) e lineações mineral e/ou de estiramento orientadas N-S e com caimentos no sentido de mergulho da $\$ 2$. Lineações de interseção entre as foliações S-C miloniticas são sub-horizontais e apresentam, em geral, direção NE-SW. Dobras fechadas a isoclinais, com eixos na direção NE-SW são observadas localmente e admitem a foliação S2 como plano-axial. Dobras em bainha ocorrem dentro do plano $S 2$ (Foto 26).

Dobras assimétricas normais D3 dobram a foliação S2. São dobras abertas a fechadas, com eixos sub-horizontais na direção NE-SW, planos-axiais sub-verticais e paralelos a uma clivagem em domínios (Foto 24B), que evolui a transposição da S2. Zonas de cisalhamento transcorrentes $F 3$, associadas a Zona de Cisalhamento Serra do Caboclo, truncam as estruturas F2 neste perfil.

No Perfil Serra Talhada-Tabuleiro (perfil B-B', anexo 2) a foliação S2 tem, em geral caimento suave para NW, tornando-se mais ingremes e até sub-verticais, próximo a zonas de cisalhamento F3. As lineações mineral e de estiramento estão essencialmente ao longo do mergulho da S2. Dobras abertas D3 são observadas deformando as estruturas F2 e também são mais fechadas quanto mais próximas de zonas transcorrentes, e, chegando a transpor a S2. O mesmo ocorre ao longo do Perfil Água Branca (perfil C-C', anexo 3). 


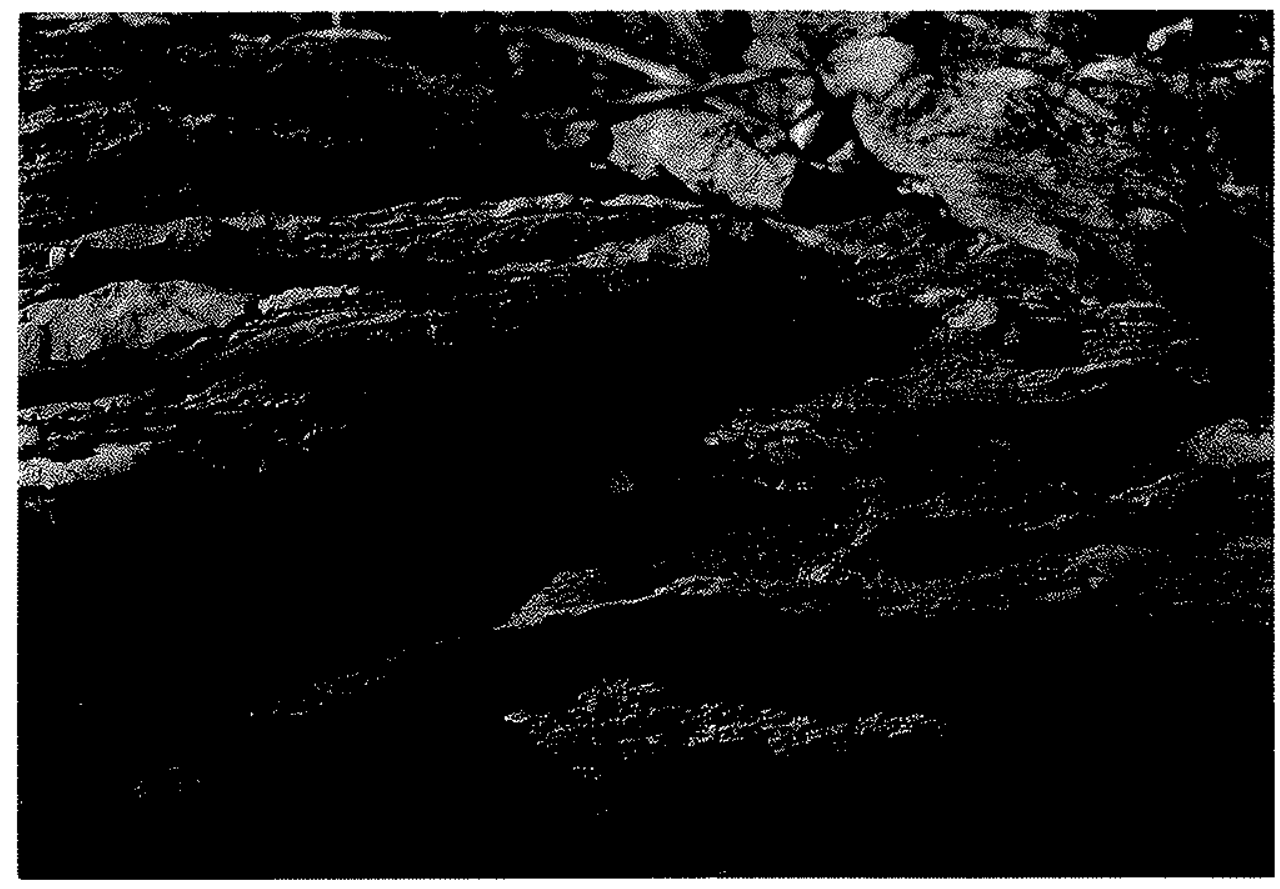

Foto 25) Quartzito com mica verde da unidade $C$ do Complexo Riacho Gravatá (Amêndoa Serra da Pinheira, a norte de Manaíra) onde pode-se observar foliação $\mathrm{S}-\mathrm{C}_{2}$ sub-horizontal.

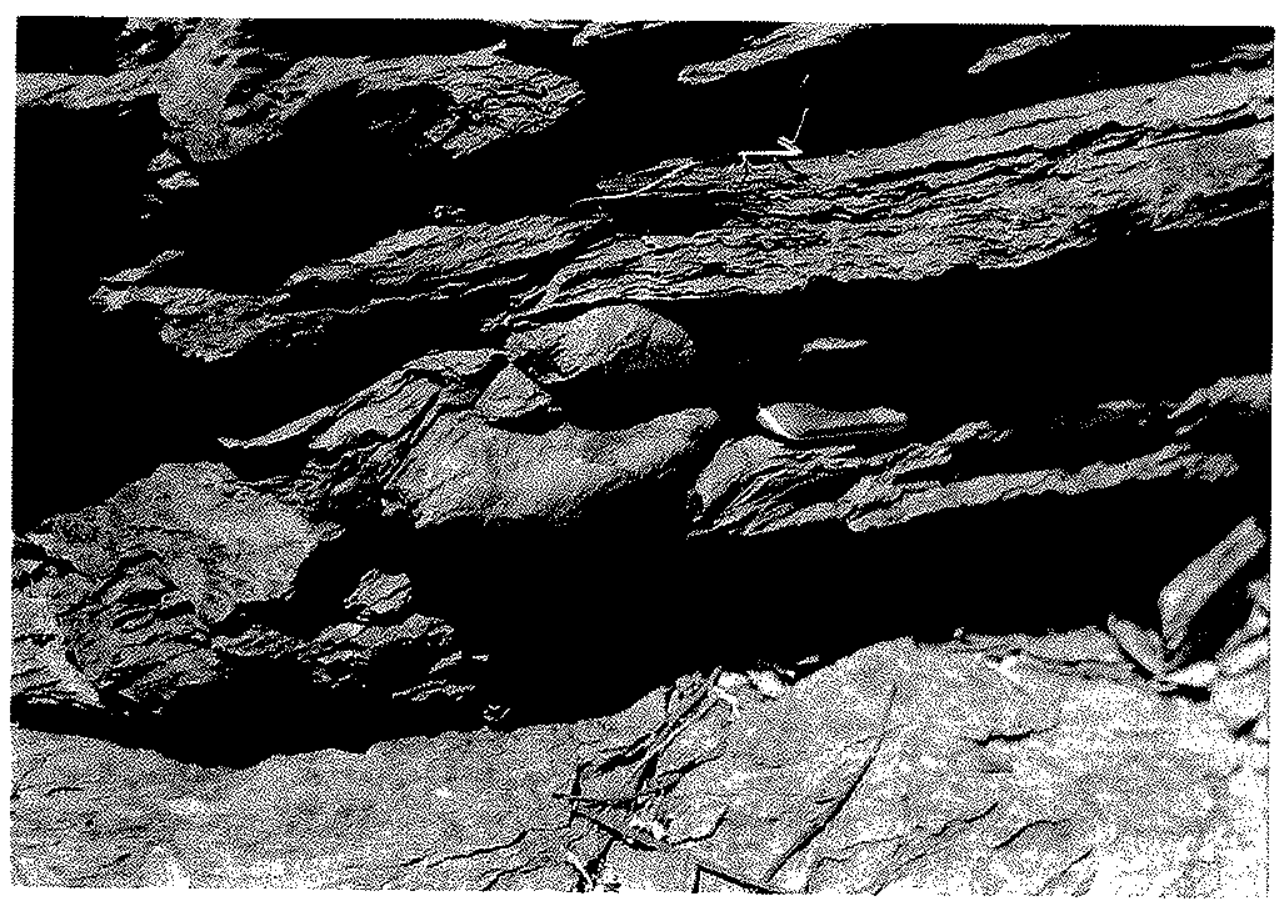

Foto 26) Tremolita-clorita xisto da unidade A do Complexo Riacho Gravatá (Amêndoa Serra da Pinheira, a norte de Manaíra), onde pode-se observar dobras em bainha na foliação S2 subhorizontal. 


\section{V.3 DOMÍNIO ESTRUTURAL SERRA DO MOCAMBO - Sistema de cavalgamentos} S2 para SE truncados por zonas de cisalhamentos transcorrentes $F 3$

Este dominio é limitado a norte pela Zona de Cisalhamento Serra do Caboclo e a sul pela Zona de Cisalhamento Jurú, esta última, de movimento dextral e direção E-W, é responsável pela ruptura das estruturas descritas no domínio Serra da Pinheira (Perfil ManaíraSantana da Mangueira).

As estruturas observadas neste domínio, podem ser visualizadas, na porção sul do Perfil Piancó-Tavares (perfil E-E', anexo 3).

A segunda fase de deformaçăo é representada pela foliação principal S2 sub-horizontal e com mergulhos suaves para NW e SE. Localmente, estruturas tipo $\mathrm{S}-\mathrm{C}_{(2)}$ protomiloniticas são observadas e definem movimento para $\mathrm{SE}$, ao longo das lineações de estiramento e/ou mineral. A foliação-S2 descreve dobras D3 assimétricas, em várias escalas, abertas a fechadas e com vergência para NW. Os planos-axiais S3 mergulham para sudeste (de $50^{\circ}$ a $90^{\circ}$ ) e os eixos são sub-horinzontais na direção NE-SW. Zonas de cisalhamento tardias, de movimentação obliqua e com componente inverso para NW, associam-se com dobras D3 quase-recumbentes e com flancos inferiores rompidos.

As zonas de cisalhamento $\mathrm{F} 3$ admitem, neste domínio, aberturas do tipo pull apart permitindo a intrusão em sheets de granitos do tipo-S e de pegmatitos com quartzo, feldspatos, biotita e muscovitas, que normalmente possuem a foliaçăo milonítica.

\section{V.4 DOMÍNIO MACACOS-PIAUS: Sistema de cavalgamentos F3 para NW}

Este domínio consiste em uma amêndoa compressiva associada a terceira fase de deformação regional. É limitado a norte pela Zona de Cisalhamento Jurú, a oeste por uma falha normal desenvolvida durante a fase F5 e responsável pelo soerguimento do bloco sudeste em relação ao bloco noroeste e, a sul, pelos ortognaisses do tipo Cariris Velhos, no domínio Alto do Teixeira-Terra Nova (Fig 18).

As estruturas descritas neste dominio podem ser observadas ao longo do Perfil Macacos-Piaus (perfil D-D', anexo 3). Domina uma foliação S3 do tipo S-C, protomilonítica e 
indicando movimento para NW (Foto 27). Ela transpõem generalizadamente a foliação-S2, que se encontra preservada nas charneiras de dobras D3. Esta transposição pode estar relacionada a um processo de rotação da foliação $S 2$ para a direção $S$ da estrutura tipo $S-C_{(3)}$, nos locais onde se desenvolvem zonas de cisalhamento F3 (Fotos 28A e B). Pequenas dobras isoclinais D2 podem também estarem preservadas nestas charneiras D3 (Foto 29). Esta rotação pode ser melhor visualizada através do giro das lineações L2, inicialmente contidas nos planos S2 (vide estereogramas no perfil D-D', anexo 3). No entanto, uma intensa crenulação da S2, com transposição e geração de bandamento diferenciado S3 parece predominar. Esse processo associa-se a um dobramento D3, inclinado a recumbente, vergente para noroeste e com direção axial NE-SW. Os flancos inferiores destas dobras estão, no geral rompidos e paralelizados a uma S3 de textura milonítica. Dobras em bainhas e dobras D2 redobradas são frequentes (Fotos $28 \mathrm{~B}$ e 29). Essas estruturas pós-S2 testemunham o incremento de strain associado ao domínio transpressivo local gerado pelo cavalgamento oblíquo para noroeste dos Xistos Sertânia e do domínio Alto Teixeira-Terra Nova.

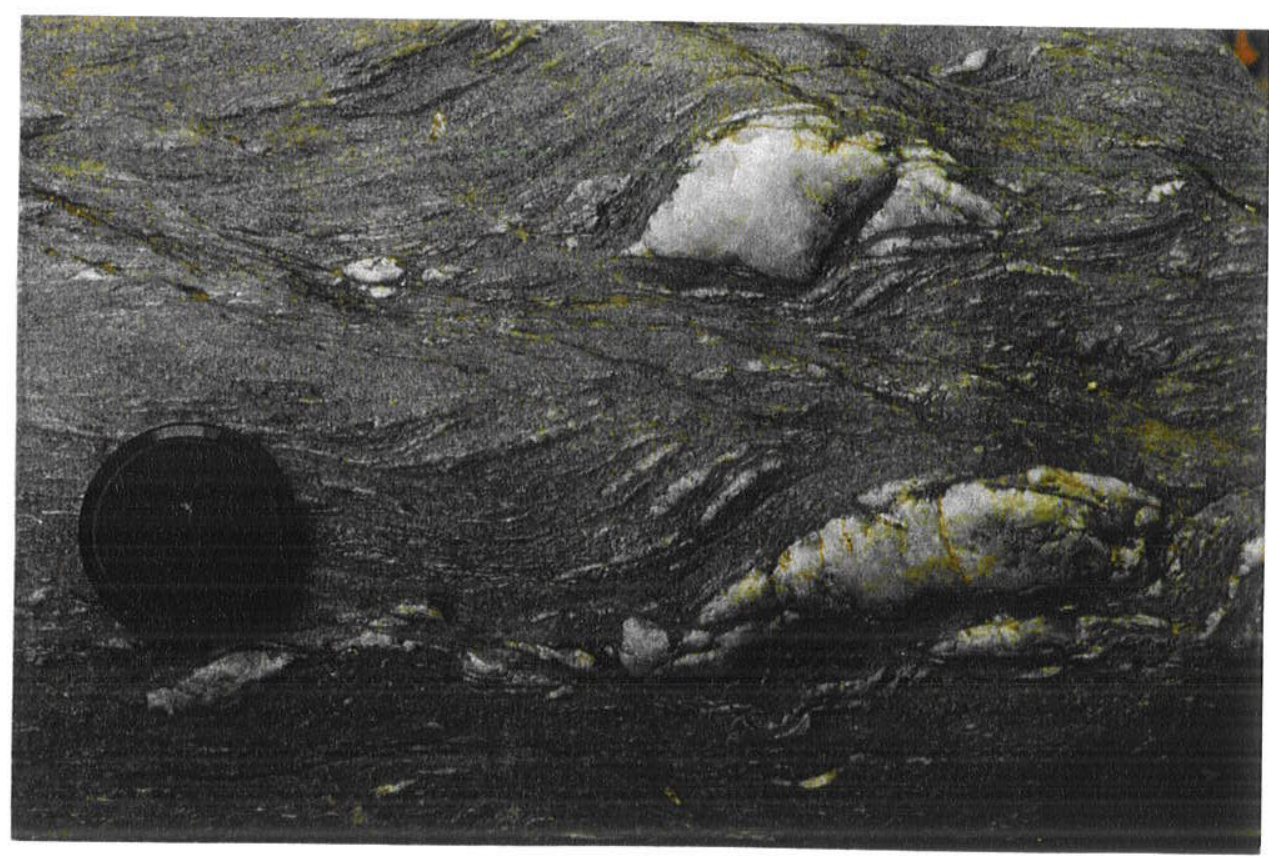

Foto 27) Granada-muscovita-biotita xisto mostrando foliação milonítica $S-C_{3}$, onde se observa vênulas de quartzo orientadas paralelas a direção $S$, e o truncamento da foliação por zonas de cisalhamentos tardias 


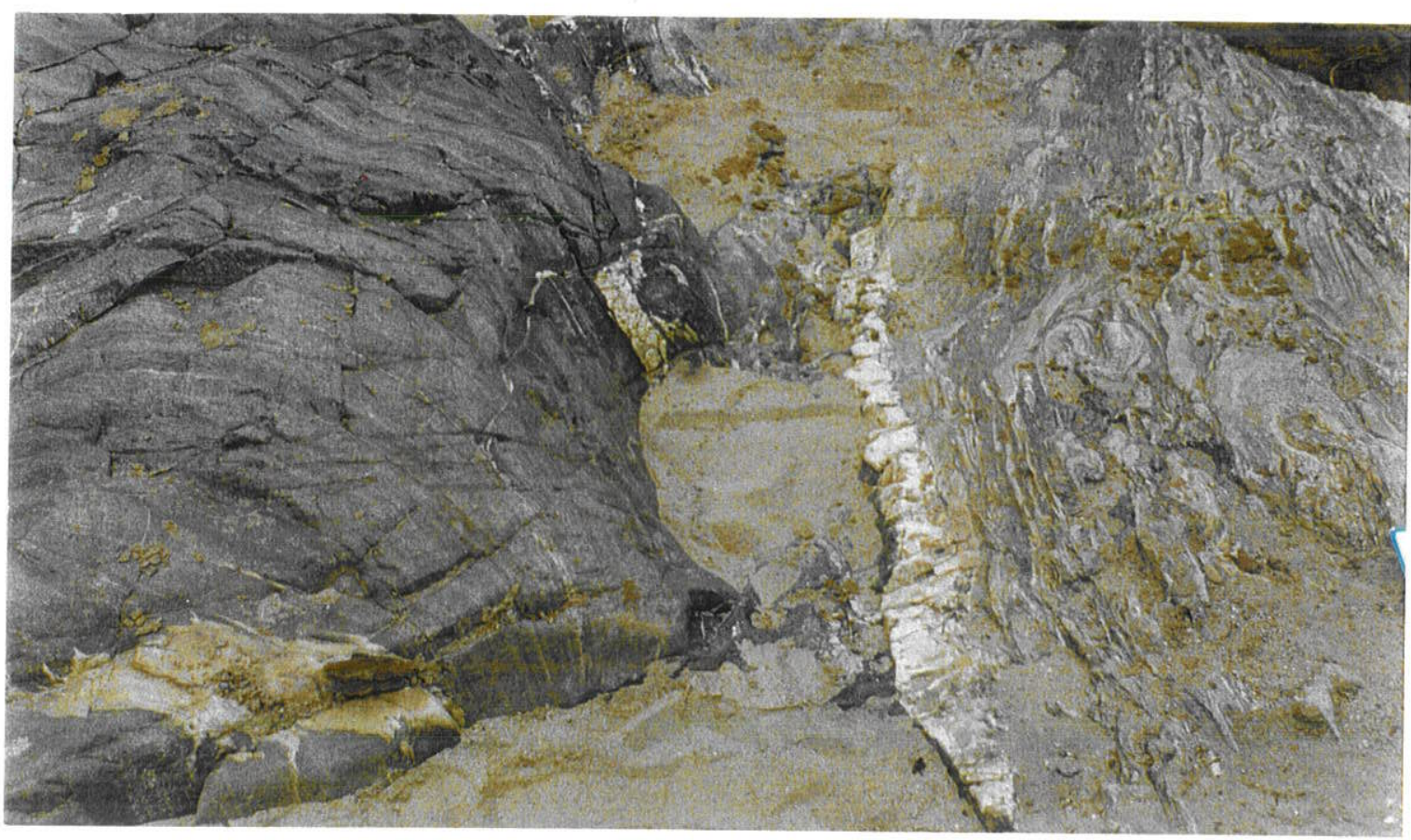

A.

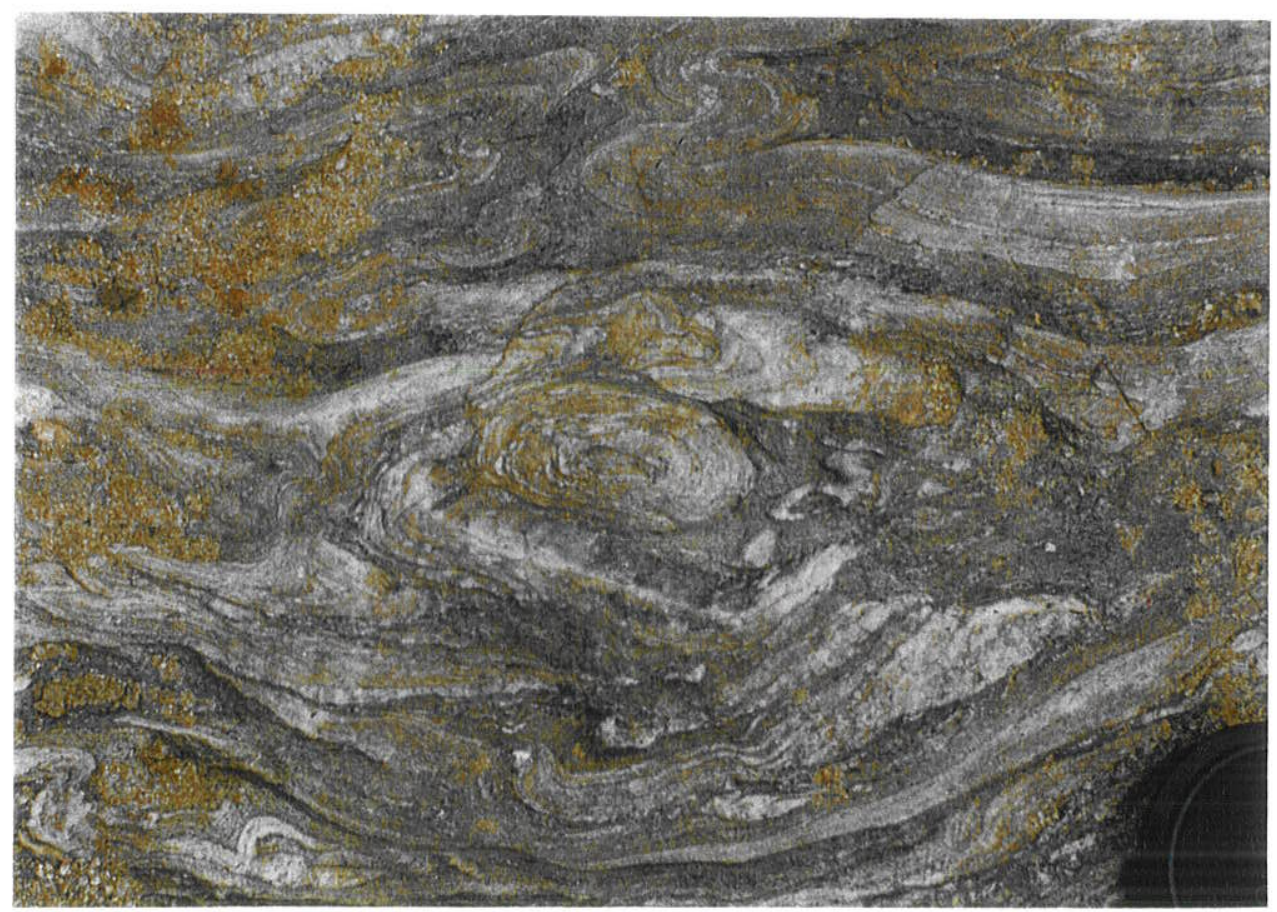

B

Foto 28) Foliação $S 2$ preservada em anfibolito bandado. No nível menos competente (gnáissico) S2 está transposta para S3 (A). Nestes locais são comuns dobras em bainhas (B) 


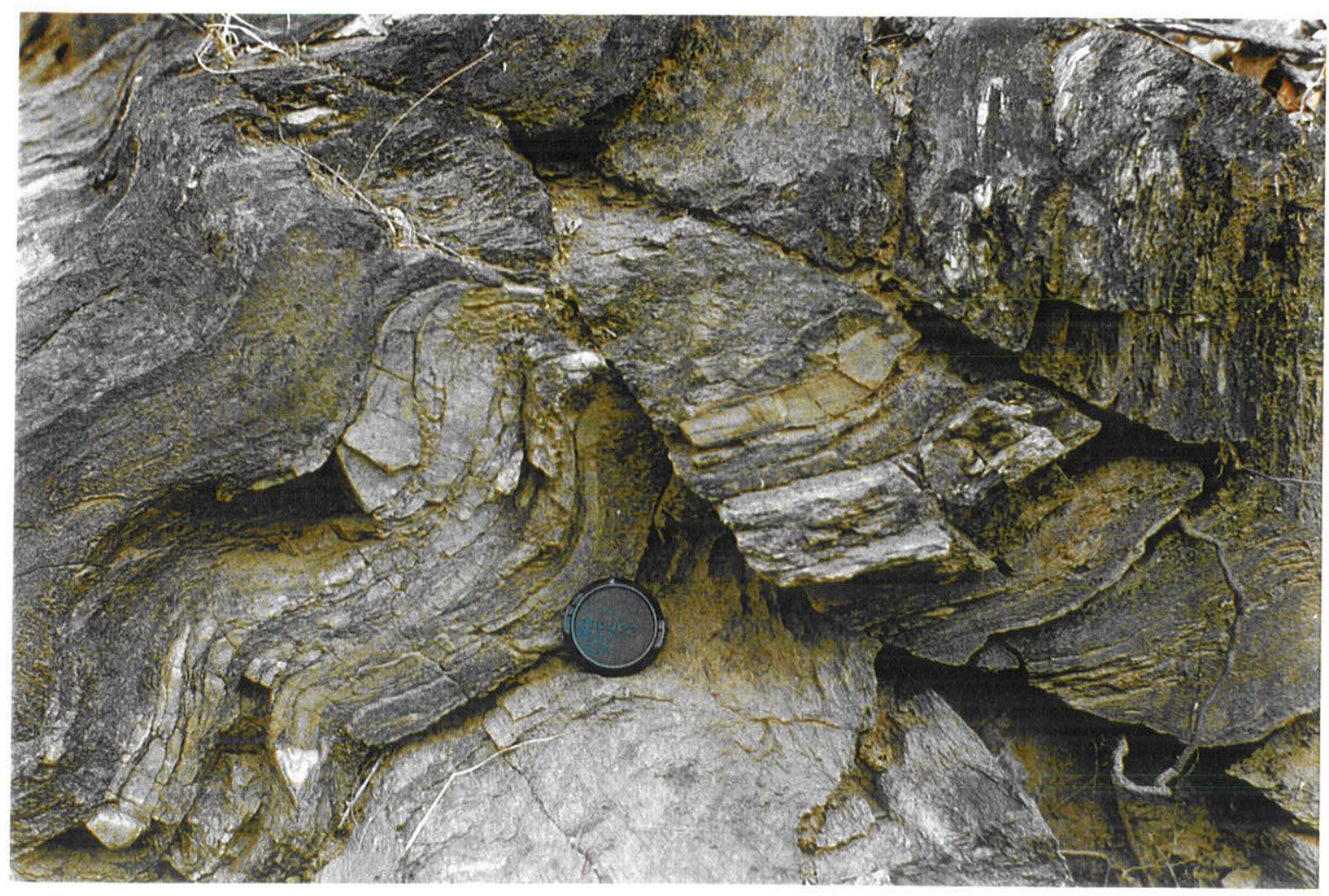

Foto 29) Dobra D3 com plano axial em leque. Observar charneiras reliquiares D2 isoclinais. Metarritimito da unidade E do Complexo Riacho Gravatá (Amêndoa Macacos-Piaus), localizado na parte norte do perfil homônimo.

\section{V.5 DOMÍNIO SERRA TALHADA - Núcleo antiformal D3 desenvolvido numa amêndoa distensiva}

O domínio estrutural Serra Talhada consiste em uma amêndoa distensiva, desenvolvida dentro de um campo de esforços NV-SE, associada a segunda fase de deformação. É limitado a norte pela Zona de Cisalhamento Serrote Varginha e a sul pela Zona de Cisalhamento Serra Talhada, de direção NE-SW e movimentação dextal. As estruturas descritas neste domínio estrutural podem ser observadas na porção sul do Perfil Serra Talhada-Tabuleiro (perfil B-B', anexo 2).

A foliação principal neste domínio é uma foliação $S 2$, definida pela orientação de minerais máficos dispostos paralelamente a um bandamento gnáissico, gerada durante o pico do metamorfismo (Foto 1). Está dobrada em um grande antiforme D3 aberto e com plano-axial 
sub-vertical e eixo NE-SW (Fig. 19). Localmente, são descritas dobras fechadas a isoclinais, muitas vezes redobradas por D3 e interpretadas como de segunda fase de deformação.

A foliação-S2 pode apresentar estruturas tipo S-C com transporte da placa superior para E.SE, no núcleo da antiforme, e para NW, no flanco norte desta, que juntamente com a alto gradiente térmico descrito neste domínio, sugere um domeamento associado a uma distensão crustal sin-D2.

Zonas de cisalhamentos paralelas a sub-paralelas ao plano axial de dobras D3 são comuns e, localmente, serviram de condutos para as intrusőes graníticas descritas neste domínio. Feições similares, em escala mesoscópica, são observadas em migmatitos e associadas a estruturas do tipo $\mathrm{S}-\mathrm{C}_{(3)}$, com fusão in situ (Foto 2 ).

\section{V.6 DOMÍNIO SANTANA DO GARROTES - Núcleo antiformal D3}

Este domínio estrutural é limitado a sul pela Zona de Cisalhamento Serra do Caboclo e a norte por falhas inversas orientadas E-W (rampa frontal ?) e com movimentaçăo para SW. Estas falhas infletem, a leste, para a direção NE-SW e passam a uma zona de cisalhamento lateral sinistral, aqui designada Zona de Cisalhamento Emas (rampa lateral ?).

As estruturas macroscópicas identificadas neste domínio podem ser observadas ao longo dos perfis Piancó-Tavares (perfil E-E', anexo 3), Manaíra-Santana da Mangueira (perfil AA', anexo 2), Piancó-Olho D'Água (perfil G-G', anexo 4) e Itaporanga-Lagoa do Arroz (perfil F$F^{\prime}$, anexo 4).

A foliação principal S2 neste domínio estrutural é definida pela orientação de minerais planares e é paralela a um bandamento composicional. A S2 encontra-se afetada por um dobramento D3, observado em todas as escalas. São dobras abertas e suaves (raramente fechadas), normais, com plano axial sub-vertical e eixos na direção NE-SW. Uma foliação plano axial S3, do tipo clivagem de crenulação ocorre localmente. Esse domínio estrutura-se em um grande antiforme D3, limitado em seus flancos por zonas de cisalhamentos de mergulho moderado a alto e transporte para sul no flanco norte e transporte para norte no flanco sul (Fig. 18 e anexos 2, 3 e 4), coerentes com uma compressão NW-SE. (Fig. 20) 


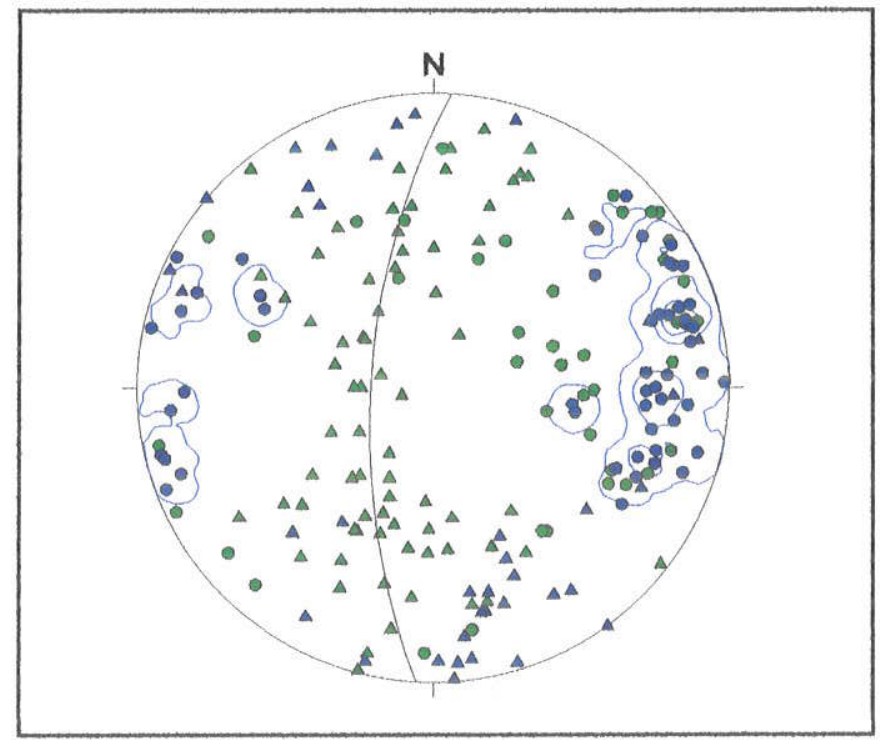

Fig. 19) Estereograma dos elementos estruturais associados a F2 e F3, do domínio antiformal Serra Talhada, obtidos no perfil homônimo (estruturas planares - $\Delta$; lineares - $O$; verde - F2; azul - F3; guirlanda definida pelos pólos de S2.
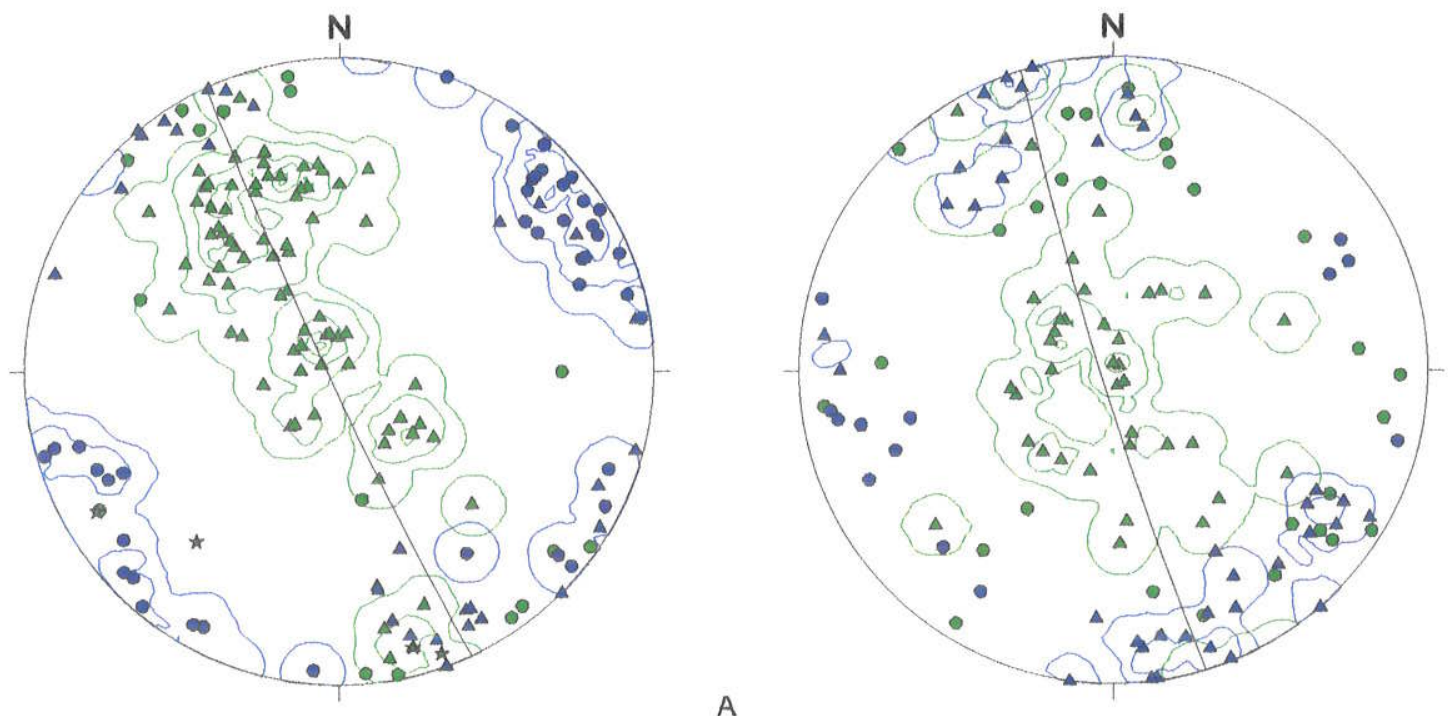

$\mathrm{S} 2=75(1,5 / 4,0 / 8,0 / 10,5 / 12,0) ; \mathrm{L} 3=40(2,5 / 7,5 / 12,5 / 17,5)$

$\mathrm{S} 2=45(2,0 / 6,5 / / 10,5) ; \mathrm{S} 3=40(5 / 10 / 15)$

Fig. 20) Estereogramas dos elementos de F2 e F3, para o domínio Santana dos Garrotes nos

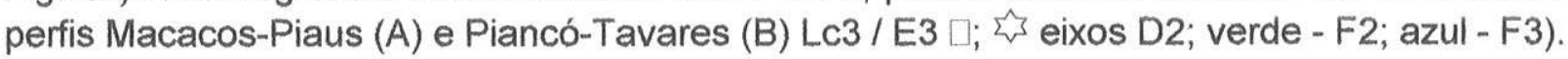




\section{7 DOMÍNIO ESTRUTURAL PIANCÓ - Núcleo Antiformal D3 desenvolvido numa amêndoa distensiva}

Este domínio estrutural é limitado a oeste pela Zona de Cisalhamento Boqueirão dos Cochos, que inflete a leste, para dentro do Lineamento Patos, e a leste e sul pela Zona de Cisalhamento Emas (rampas lateral e frontal). As estruturas descritas no domínio Piancó podem ser observadas na porção norte dos perfis Piancó-Tavares (perfil E-E', anexo 3 ) e Itaporanga-Lagoa do Arroz (perfil G-G', anexo 4) e Itaporanga-Mata Velha (perfil H-H', anexo 3).

A principal estrutura observada neste domínio é uma foliação $\$ 2$, via de regra subhorizontal, com lineações de estiramento e/ou mineral, geralmente, down dip. Esta foliação está dobrada numa grande antiformal aberta, associada a F3. Dobras parasíticas abertas a fechadas, apresentam planos axiais sub-verticais e eixos na direção E-W e NE-SW. No flanco sul deste grande antiformal, as dobras parasiticas ficam mais fechadas e reclinadas, e seus flancos inversos degeneram em zonas de cisalhamento de mergulho moderado a íngreme com movimento transversal associado a movimentos direcionais. Nestes locais são comuns dobras redobradas e dobras em bainha (Foto 30 ).

Localmente, S2 apresenta estruturas tipo S-C miloníticas, que definem transporte da placa superior para SE, no flanco sul da antiforme, e transporte para $E$, na zona de charneira. Esta cinemática, juntamente com o alto gradiente térmico observado na foliação $S 2$, configura um domeamento associado a distensão sin-F2. Esta estrutura, assim como a descrita no domínio Serra Talhada, foi intensificada pela transpressão, controlada pelas zonas de cisalhamentos laterais associada a F3. Esta intensificação da deformação gera o antiforme D3, com vergência para Se e inversão do flanco inferior que degenera em rampas frontais da Zona de Cisalhamento Emas.

\section{V.8 DOMINIO ESTRUTURAL SERRA DO OLHO D'ÁGUA - Estratificação $S_{0}$ dobrada por D3}

O domínio Serra do Olho D'Água ocorre na porção meridional da área do presente trabalho. Está limitada a sul e a norte pela Zona de Cisalhamento Serra do Caboclo, como uma lente pull apart. Constitui um domínio estrutural distinto dos demais descritos anteriormente, 
pois nele a primeira fase de deformação corresponde a dobras normais fechadas, orientadas na direção NE-SW (perfil A-A', anexo 2) e que dobram a estratificação sedimentar $S_{0} e$ admitem uma clivagem plano-axial. A estratificação é definida por estruturas sedimentares geopetálicas do tipo acamadamento gradacional. Caracteriza-se também pela ausência da foliação metamórfica regional, que nesta região atinge a zona da biotita. As dobras descritas como estruturas tectônicas de primeira geração, são correlacionáveis ao dobramento D3.

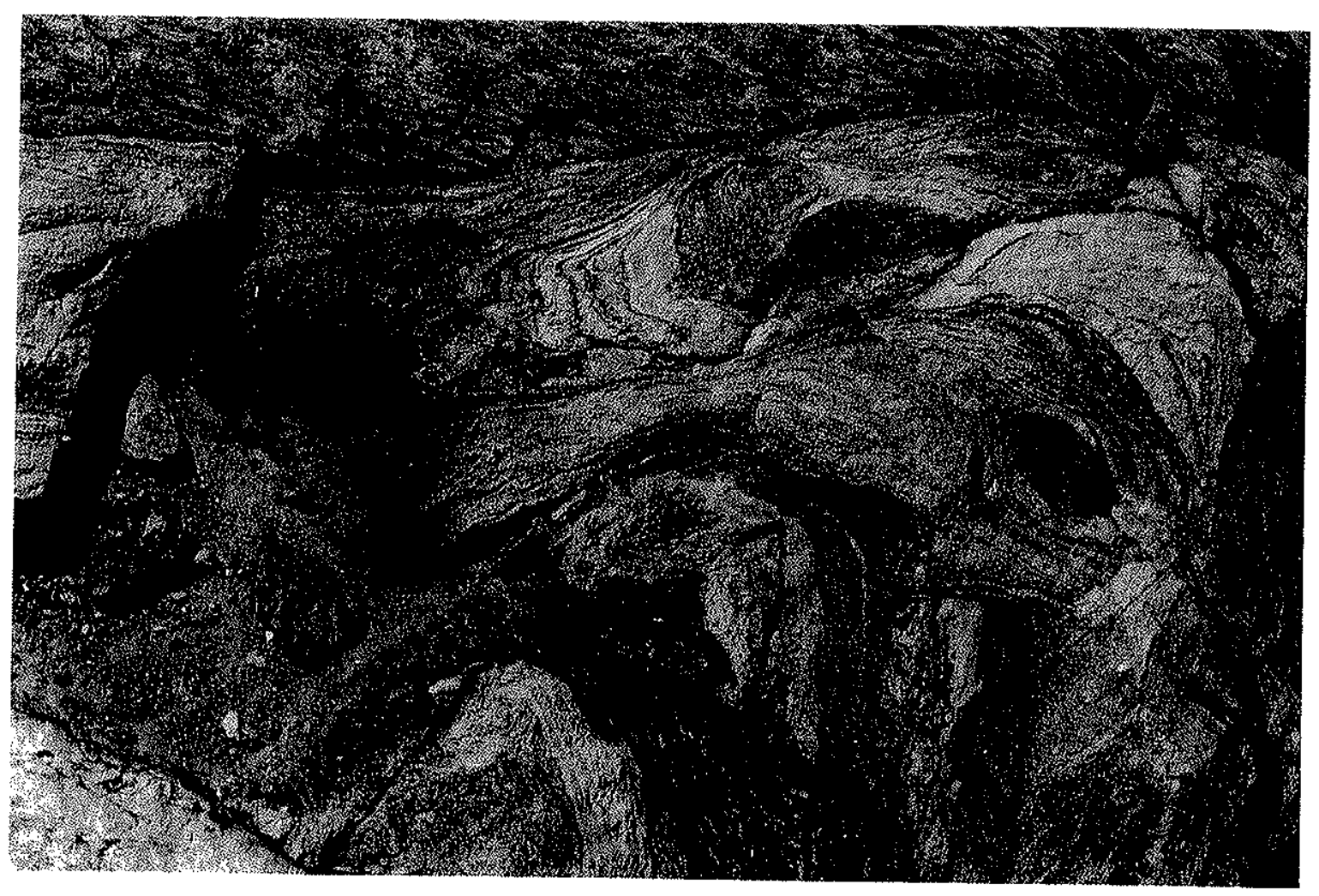

Foto 30) Muscovita-biotita gnaisse da Sequência Piancó, localizado no flanco sul da antiforme, onde observa-se zonas de cisalhamentos desenvolvidas no plano axial de dobras D3. Nestes locais são comuns dobras redobradas e dobras em bainha. 


\section{CONCLUSÕES}

A Faixa Piancó Alto Brígida, localizada no Domínio Tectônico Rio Pajeú é constituída por distintos terrenos tectono-estratigráficos (no sentido de Coney, 1989), desenvolvidos sob regimes metamórficos e deformacionais contrastantes, justapostos durante a orogênese brasiliana (750 a $580 \mathrm{Ma})$.

Diferentes sequências estratigráficas foram identificadas: o Complexo Serra Talhada, o Complexo Riacho Gravatá, os Xistos Sertânia, o Complexo Cachoeirinha e a Sequência Serra do Otho D'Água.

O Complexo Serra Talhada, constituído por ortognaisses e migmatitos, representa uma unidade do Paleoproterozóico (ou mais antiga) que sofreu intrusões de ortognaisses tipo Cariris Velhos (Neoproteozóico-Toniano) e que foi metamorfoseada e submetida a processos de fusão parcial durante o Brasiliano (Neoproterozóico III). Granitóides intrusivos tipo Itaporanga (batólitos de Taváres e Princesa Isabel) e granitos peraluminosos mais jovens também estâo presentes neste complexo, que ocorre dentro do domínio do terreno Alto Teixeira-Terra Nova.

O Complexo Riacho Gravatá constitui uma sequência metavulcanossedimentar da passagem Esteniano/Toniano (Meso-Neoproterozóico). As rochas metavulcânicas, com idades de cristalização no intervalo entre 1100 a 980 Ma e TDM paleoproterózoico, possuem uma assinatura química sugestiva de um magmatismo intraplacas de regime extensional. Dentro deste complexo, foram individualizados três domínios tectono-estratigráficos, designados de amêndoas: Serra da Pinheira, Serra do Mocambo e Macacos-Piaus. Estruturas sedimentares preservadas (depósitos por correntes de turbidez na Amêndoa Serra do Mocambo) e presença de rochas carbonáticas (metamargas na Amêndoa Serra do Mocambo e mármores na Amêndoa Macacos-Piaus), sugerem depósitos em ambiente plataformal, passando, para SW para ambientes de águas mais profundas.

O Complexo Cachoeirinha, de origem metavulcanossedimentar, é constituído por duas sequências distintas: 1) Sequência Piancó, mais a norte, onde predominam metapelitos associados a metagrauvacas e metavulcânicas ácidas e básicas, alcançando o fácies anfibolito alto até condições de anatexia; e a 2) Sequência Santana dos Garrotes, mais a sul, onde predominam metapelitos com intercalações de metapsamitos, de metagrauvacas e de metarenitos liticos, associados a metavulcânicas ácidas e básicas, estas com assinatura geoquímica de vulcanismo de arco magmático em zonas de convergência de placas (Jaziel, 
1998). Apesar da ausência de estruturas sedimentares preservadas, o zoneamento dos depósitos, que passam dos arenitos líticos e metagrauvacas na Sequência Santana dos Garrotes, para os metapelitos típicos na Sequência Piancó, sugere, para estes últimos, uma posição mais distal. As idades $\mathrm{U}-\mathrm{Pb}$ em zircões destas metavulcánicas posicionam o Complexo Cachoeirinha no Neoproterozóico-Criogeniano, definindo-o como uma sequência deposicional do ciclo Brasiliano.

Os Xistos Sertânia afloram na borda sul do Alto Teixeira-Terra Nova. São metagrauvacas interpretadas como contemporâneas ao vulcanismo MesoproterozóicoEsteniano da Faixa Pajeú-Paraíba (Santos, 1995; Brito Neves et al., 1995).

A Sequência Serra do Olho D'Água parece representar um depósito tipo-molassa, tardio à orogênese Brasiliana, devido a presença de seixos de rochas dos complexos Riacho Gravatá e Cachoeirinha, alguns dos quais mostrando a foliação metamórfica principal bem desenvolvida; e devido a ausência de estruturas correlacionáveis a segunda fase de deformação regional (sua foliação metamórfica é primária e correlata à terceira fase de deformação regional).

A estruturação da Faixa Piancó-Alto Brígida está associada a um sistema de cisalhamento transcorrente que define diferentes domínios estruturais, designados: Piancó, Santana dos Garrotes, Serra do Olho D'Água, Serra Da Pinheira, Serra do Mocambo e Macacos-Piaus. Esse sistema transcorrente superpõem-se a estruturas relacionadas ao metamorfismo principal materializado na foliação regional $\$ 2$. A foliação $\$ 2$ pode se desenvolver sob regime de cisalhamento dúctil, em uma estrutura do tipo S-C sub-horizontal e associada a um transporte para sudeste. Nos domínios Serra do Mocambo e Serra da Pinheira esse cisalhamento dúctil está associado a um sistema de cavalgamento; nos domínios Piancó e Serra Talhada o transporte sin-metamórfico define um regime extensional associado ao alto gradiente térmico observado.

A terceira fase de deformação F3 é representada pelo sistema de cisalhamnento transcorrente, destacando-se: 1- a Zona de Cisalhamento Serra do Caboclo que, na área do presente trabalho, delimita o noroeste do Complexo Riacho Gravatá; 2- a Zona de Cisalhamento Jurú, de caráter mais tardio, truncando dobras D3 da Amêndoa Serra da Pinheira em sua continuidade para a Amêndoa Serra do Mocambo; 3- a Zona de Cisalhamento Boqueirão dos Cochos que se inflete de NE para a direção $E-W$ e delimita, a norte, o Complexo Cachoeirinha. A esta terceira fase de deformação associam-se dobras em todas as escalas, que de normais e abertas, passam a inclinadas e fechadas nas imediações das zonas de cisalhamento. São dobras que desenvolvem uma foliação plano-axial, no geral como clivagem de crenulação e que grada a uma foliação milonítica sub-vertical. Localmente, em 
regime transpressivo, um dobramento inclinado, assimétrico e quase isoclinal, vergente para NW, ou para SE, dobra a foliação S2.

Duas fase de deformação posteriores, desenvolvidas em níveis crustais superiores, associam-se a um regime distensivo, evidenciado pelas numerosas intrusões de diques básicos e de sienitos.

Dados de geotermometria e geobarometria obtido em rochas dos complexos Serra da Pinheira e Cachoeirinha e nos Xistos Sertânia indicam condições contrastantes para o auge metamórfico quando do desenvolvimento da foliação $\$ 2$ :

1) a Sequência Piancó (Complexo Cachoeirinha) possui condições metamórficas mínimas de cerca de $700^{\circ} \mathrm{C}$ e $4,5 \mathrm{Kbar}$, retrometamorfisada, na terceira fase deformação, a uma temperatura de $430^{\circ} \mathrm{C}$ e pressão de $4 \mathrm{Kbar}$, sugerindo um resfriamento quase isobárico. O paleogradiente geotérmico, para o pico do metamorfismo, encontrava-se a cerca da $42^{\circ} \mathrm{C} / \mathrm{Km}$;

2) considerando uma pressão arbitrada de $5 \mathrm{Kbar}$ para os metassedimentos da Sequencia Santana dos Garrotes (Complexo Cachoeirinha) admitem uma temperatura entre $540^{\circ} \mathrm{C}$ e $500^{\circ} \mathrm{C}$, que passa, a sul, para valores de $480^{\circ} \mathrm{C}$;

3) nas rochas do Complexo Riacho Gravatá, Amêndoa Macacos-Piaus, as temperaturas para o centro e borda dos minerais, calibradas em metassedimentos, encontramse entre $450^{\circ} \mathrm{C}$ e $500^{\circ} \mathrm{C}$ e as pressões entre 7,3 e $8,0 \mathrm{Kbar}$. As temperaturas para as recristalizaçōes retrometamórficas estão estimadas no intervalo $480^{\circ} \mathrm{C}$ e $450^{\circ} \mathrm{C}$, calculadas para pressão arbitrada de $8 \mathrm{Kbar}$. Nos anfibolitos, as temperaturas mínimas para 0 auge metamórfico ficam entre $450^{\circ} \mathrm{C}$ e $660^{\circ} \mathrm{C}$ e as pressões, entre 8,0 e $10,0 \mathrm{Kbar}$. Nas bordas as temperaturas são similares às do centro, porém as pressões são relativamente mais baixas (7,5 e $8,0 \mathrm{Kbar})$. Temperaturas para as fases minerais retrometamórficas, calculadas arbitrariamente para pressões de $8,0 \mathrm{Kbar}$, encontram-se entre $450^{\circ} \mathrm{C}$ e $480^{\circ} \mathrm{C}$. Um paleogradiente geotérmico médio de $16^{\circ} \mathrm{C} / \mathrm{Km}$ pode ser vislumbrado;

4) na Amêndoa Serra da Pinheira (Complexo Riacho Gravatá) a temperatura mínima para o metamorfismo varia de $560^{\circ}$ a $470^{\circ} \mathrm{C}$, a uma pressão de $4,0-5,0 \mathrm{Kbar}$. As associações minerais retrometamórficas indicam uma temperatura de $469^{\circ} \mathrm{C}$. O paleo-gradiente geotérmico para o pico do metamorfismo é de cerca de $25^{\circ} \mathrm{C} / \mathrm{Km}$;

5) para a faixa de Complexo Riacho Gravatá que ocorre a leste do Complexo Serra Talhada, foram obtidas temperaturas da ordem de $612^{\circ} \mathrm{C}$ e pressões de $9,0 \mathrm{Kbar}$, para o pico do metamorfismo, e temperaturas de $571^{\circ} \mathrm{C}$, para uma pressão de $8,9 \mathrm{Kbar}$ para o retrometamorfismo, indicando condições metamórficas compatíveis com um paleogradiente 
geotérmico de $17^{\circ} \mathrm{C} / \mathrm{Km}$, similar ao observado para o Complexo Riacho Gravatá na Amêndoa Macacos-Piaus;

6) nos Xistos Sertânia a temperatura minima para o pico do metamorfismo atingiu $660^{\circ} \mathrm{C}$ a uma pressão de $4,0 \mathrm{Kbar}$, passando à borda a temperaturas mais elevadas $\left(670^{\circ} \mathrm{C}\right)$, que nas fases associadas a paragêneses pós-S2, atinge $700^{\circ} \mathrm{C}$. Este aumento na temperatura, condiz com a presença de granada sobrecrescendo a foliação $S 2$, explicada pelo domeamento e ascensão do Complexo Serra Talhada (ortognáissico migmatítico), em um posicionamento crustal distinto do Complexo Riacho Gravatá. O paleo-gradiente geotérmico para o pico do metamorfismo nestes xisto é de $42^{\circ} \mathrm{C} / \mathrm{Km}$.

As condições metamórficas contrastantes, apontam para distintos ambientes tectônicos e sugerem distintos regimes deformacionais e um grande transporte de lâminas crustais durante a extrusão e justaposição dos distintos terrenos tectono-estratigráficos.

O baixo gradiente térmico expresso pelas rochas do Complexo Riacho Gravatá na Amêndoa Macacos-Piaus é compativel com metamorfismo em zonas de subducção (Spear, 1993). Por outro lado, na amêndoa (antiformal) Piancó e, nos Xistos Sertânia, as condições metamórficas admitem paleogeotermas comprimidas e paleogradiente térmico abrupto, típicos de crostas adelgaçadas e submetidas a alto fluxo térmico, o que permite, regionalmente, a ascensão da temperatura à níveis crustais mais altos (McKenzie, 1978; Royden et al, 1980), como em domínios extensionais. Os registros comparáveis a ambientes de subducção preservados na Amêndoa Macacos-Piaus devem estar relacionados a um processo de underthrust, de crosta continental relativamente fria, dirigido para noroeste à profundidades de $30 \mathrm{~km}$.

Seis suítes plutônicas distintas, sendo cinco delas Brasilianas e uma da idade Cariris Velhos foram identificadas na região e descritas conforme a classificação das rochas graníticas Brasilianas proposta por Almeida et al (1967) para a Província da Borborema.

1) Os granitos do tipo Conceição cálcio-alcalinos, têm idades do Neoproterozóico III e de afinidades com arco magmático. Os plutons desta suíte localizados a norte da Zona de Cisalhamento Serra do Caboclo, possuem dados Sm-Nd que indicam como protólito uma fonte crustal de idade mesoproterozóica, enquanto aqueles que ocorrem a sul desta referida zona de cisalhamento, exibem $T_{D M}$ que indicam como protólito uma fonte crustal paleoproterozóica.

Granitos porfiriticos do tipo Itaporanga, de composição cálcio-alcalino potássica e assinatura química compativel com granitos intraplacas, tardi-colisionais (Neoproterozóico IIICambriano), apresentam dados isotópicos $\mathrm{Sm}-\mathrm{Nd}$ com características inversas às dos granitos tipo Conceição. 
Estes dados apontam para um cenário pré-colisional onde no terreno Piancó-Alto Brígida, crosta mesoproterozóica com provável infraestrutura extremamente adelgaçada paleoproterozóica e cobertura neoproterozóica ocorrem e terreno AltoTeixeira-Terra Nova crosta mesoproterozóica com infraestrutura paleoproterozóica ocorrem. No cenário sin a póscolisional a infraestrutura paleoproterozóica dos dois terrenos participa mais ativamente da geração de magmas.

3) Granitos do tipo Catingueira, representado pelo BatólitoTriunfo, considerado como granito do tipo-I, tardi-orogênico originado a partir de protólito crustal de idade provável Paleoproterozóica, também é coerente com o especulado acima.

4) Gabros tipo Taperoá, representados na área da presente tese, pelo gabro do Alto Vermelho, tardi-orogênico, não apresentam dados Sm-Nd confiáveis, podendo ter tido protólito de idade Cariris Velhos ou mesmo material juvenil Brasiliano.

5) Granitos tipo $S$ descritos localmente, são tardi-orogênicos.

6) Ortognaisses de idade Cariris Velhos com idades U-Pb entre 920 e $1040 \mathrm{Ma}$, são granitos do tipo $\mathrm{S}$, cujos dados $\mathrm{Sm}-\mathrm{Nd}$ sugerem protólito originado pela mistura entre crosta paleoproterozóica, ou mais antiga, e material juvenil Cariris Velhos. 


\section{REFERÊNCIAS BIBLIOGRÁFICAS}

ACCIOLY, A.C. DE A. -1993- Caracterização Petrográfica, Metamórfica e Litogeoquímica das Rochas Meta-Vulcânicas e Metapelíticas da Região de Serra Talhada - PE. Dissertação de Mestrado, C.T.- DEGEO, UFPE,172 p. (inédito).

ALMEIDA, C. N. DE -1995- Estudo das Rochas Metamáficas de ltatuba (PB) e das Ocorrências de Fe-Ti a elas Associadas; Tese de Mestrado, CT-UFPE, 129 p..

ALMEIDA, F.F.M. DE; HASUI, Y. \& BRITO NEVES, B.B. DE -1976- The Upper Pré-cambrian of South America; Bol. Inst. Geoc. , USP, São Paulo, b. 7, p. 45-86.

ALMEIDA, F.F.M. DE; LEONARDOS JR, O.H. \& VALENÇA, J.G. -1967- Granitic Rocks of North-East South América: in IUGS/UNESO Symposiun, Recife; Spec. Publ.,41 p..

ARANOVICH, L.Y. \& PODLESSKII, K.K. -1983- The Cordierite-Granet-Sillimanite-Quartz Equilibrium: Experiments and Aplication. Saxena S.K. (ed.), Springer-Verlag, NY, Advances in Physical Geochemistry, Kinetics and Equilibrium in Mineral Reactions, 3, p.172-198.

BARBOSA, O. -1970- Geologia Econômica de Parte da Região do Médio São Francisco, Nordeste do Brasil; RJ, DNPM/DFPM, b. 140, 97 p..

BELL, T.H. \& HUBENACH, M.J. -1983- Sequential Porphyroblast Growth and Crenulation Cleavage Development During Progressive Deformation. Tectonophysics, 92, p.171-194.

BEURLEN, H. -1988- Fazenda Esperança (Bodocó) e Riacho da Posse (Floresta): Duas Ocorrências Atipicas de Fe-Ti no Estado de Pernambuco; Tese Prof. Titilar, C.T.-DEGEOUFPE, Recife, $72 p$..

BEURLEN, H.; PESSOA, R.R.; ALMEIDA, C.N. DE \& ALENCAR, S.G. DA S. -1991- Itatuba (PB): Novas Ocorrências de Eclogitos Proterozóicos Associados a Minério de Fe-Ti na Província Borborema; in: XIV Simp. Geol. NE, Recife, Atas, SBG, p. 236-239.

BEURLEN, H.; SILVA FILHO, A.F. da; GUIMARÃES, I.P. \& BRITO, S.B. -1992- Proterozoic CType Eclogites Hosting Unusual Ti-Fe $\pm \mathrm{Cr} \pm \mathrm{Cu}$ Mineralization in Northeastern Brazil, Precam. Res., 58, p.195-214.

BEURLEN, H. \& VILLAROEL, H.S. -1990- Petrografia de Duas Ocorrências de Prováveis Eclogitos em Bodocó e Floresta no Estado de Permambuco, Brasil; Rev. Bras. Geoc., v. 20, n. $1-4$, p. $111-121$.

BITTAR, S.M.B.; ACCIOLY, A.C.A. \& LIMA, E.S. DE -1992- Sequência MetavulcanoSedimentar na Região de Serra Talhada - PE: Grupo Salgueiro ou Grupo Cachoeirinha?; In: 37 Cong. Bras. Geol., São Paulo, SP, Bol Res. Exp., vi 1, p. 304-305. 
BLUNY, J.D. \& HOLLAND, T.J.B. -1990- Calcic Amphibole Equilibria and a New AmphibolePlagiociase Geothermometer. Contr. Min. Petr., 104, 208-224.

BOUMA, A.H. -1962- Turbidites Sedimentology of Flysch Deposits. Elssevier, Amsterdam, 168 p..

BRITO NEVES, B.B. DE -1975- Regionalização Geotectônica do Pré-Cambriano Nordestino; Tese de Doutorado, IG/USP, São Paulo, 190 p..

BRITO NEVES, B.B. DE -1983- O Mapa Geológico do Nordeste do Brasil, Escala 1/1.000.000; Tese de Livre Docência, IG/USP,177 p.

BRITO NEVES, B.B. DE; VAN SCHMUS, W.R. \& BASEl, M.A. S. -1990- Contribuição ao Estudo da Evolução Geocronológica do Sistema de Dobramentos Piancó-Alto Brigida; In: 36 Cong. Bras. Geol, Natal, RN, Anais, v.6, p.2697-2710.

BRITO NEVES, B.B. DE; VAN SCHMUS, W.R.; SANTOS,E.J. DOS; CAMPOS NETO, M. DA C. \& HOZUCH, M. -1995- O Evento Cariris Velhos na Província Bordorema: Integração de Dados, Implicações e Paspectivas. Ver. Bras. Geoc., 25 (4), p.279-296.

CAMPOS NETO, M. DA C.; BRITO NEVES, B.B. DE \& BITTAR S.M.B. -1994a- Evoluçăo Tectônica do Nordeste Meridional: Sistema Piancó-Alto Brígida; Rel. FAPESP Geociências 92/20979-5, 60 p. (inédito).

CAMPOS NETO, M. DA C.; BITTAR S.M.B. \& BRITO NEVES, B.B. DE -1994b- Dominio Tectônico Rio Pajeú - Província Borborema: Orogêneses Superpostas no Ciclo BrasilianolPan-Africano; In: 38 Cong. Bras. Geol., Balneário de Camboriú, SC, Bol. Res. Expan., v. 1, p. 221-222.

CONEY, P.J. - 1989- Structural Aspectes of Suspect Terranes and Accretionary Tectonics in Western North America. Journ Struct. Geol., 11: 107-125

CUNHA, M.A.L. da -1996- Petrologia, Geoquímica e Profundidade de Posicionamento dos Stocks Graníticos-Tonalíticos de Boa Ventura, Conceição e Pedra Branca PB. Dissertação de Mestrado, UFPE, CT DEGOE, $154 \mathrm{p}$.

DEER, W.A.; HOWIE, R.A. \& ZUSSMAN, J. -1975- Minerais Constituintes das Rochas - Uma introdução, Fundação Calouste Gulbenkian, Lisboa, 558 p.

DERBY, O.A. -1881- Contribuição para o Estudo do Vale do Rio São Francisco, Arch. do Museu Nac., RJ, v. IV, p..

DOMBRE, L.E. -1893- Viagem do Engenheiro Dombre ao Interior da Província de Pernambuco em 1874 e 1875, Recife,

DUKE, W.L.; ARNOTT, R.W.C. \& CHEEL, R.J. -1991- Shelf Sandstones and Hummocky Cross Stratification: New Insights on a Stormy Debate. Geology, 19 (5/6), p.667-677. 
EBERT, H. -1955b- Pesquisa na Parte Sudeste de Minas Gerais e no Poligono das Secas, Rel. An. do Dir., DGM, ano de 1954, p.79-89.

EBERT, H. -1957- A Subdivisão Estrutural e Estratigráfica da Parte Oriental do Escudo Brasileiro, Conf. proferida no XIX Cong. Bras. de Geol.

EBERT, H. -1964- Tectônica e Metamorfismo Regional do Escudo Brasileiro, SUDENE, Dep. Rec. Min., Div de Geol.,Rel.(circulação interna), 49p.

EBERT, H. -1969- Structural Units of the Brazilian Pré-Cambrian Shield and its Probable Relations with the Guiana Shield, Verhandelingen, Kon. Ned. Geol. Mijnbouwk. Gen., v.27, p. 147-150. (anexo 3)

EBERT, H. -1969- Geologia do Alto Seridó: Note Explicativa à Folha Currais Novos 1:250.00; DRM/DG, Série Geologia Regional, n. 11, 117p.

FERREIRA, V.P. -1986- Petrologia e Geoquímica das Rochas Peralcalinas do Cinturão de Dobramentos Cachoeirinha-Salgueiro, Nordeste do Brasil. Dissertação de Mestrado, Dep. Geol UFPE, Recife

FERREIRA, V.P.; SIAL, A.N.; LONG, L.E. \& PIN, C. -1997- Isotopic Signatures of Mesoproterozóic to Cambrian Ultrapotássic Syenitic Magmas, Noertheastern Brazil: Evidence for a Enched Mantle Source

FERREIRA, V.P. -1991- Petrology and Geochemistry of the Late Proterozoic Ultrapotassic Peralkaline Triunfo Batholith and Related Dikes, State of Pernambuco, Noertheast Brazil, University of Georgia, PhD Dissert., 269 p..

FERREIRA, V.P. \& SIAL, A.N. -1986- The Peralkaalic Magmatism in the Precambrian Cachoeirinha-Salgueiro Foldbelt, Northeast Brazil: Geichemical aspects. Rev. Btas. Geol., $16 ; 73-85$.

FERRY, J.M. \& SPEAR, F.S. -1878- Experimental Calibration of the Partitioning of Fe and Mg between Biotite and Garnet. Contr. Min. Petrol., v. 66, p. 113-117.

FIGUEIREDO, L.L. DE; MONIE, P.; FERRAUD, G.; CABY, R.; CORSINI, M. ARTHAUD, M. \& VAUCHEZ, A. -1992- Durée des Événements Tectono-Metamorphiques dans les Chaines Proterozoiques: Premiers Resultats ${ }^{40} \mathrm{Ar} \mathrm{r}^{38} \mathrm{Ar}$ sur le NE du Brésil. Réunion des Sciênces de la Terre, 14, Toulouse, France: Societé Géologique de France, Résumé, p.63.

FONSECA, A. DA S. S. - 1996- Petrologia e Litogeoquímica das Rochas Metavulcânicas do Complexo Irajai a NW de Sertânia - PE. Dissertação de Mestrado, Centro de Tecnologia, DEGEO/UFPE, $105 \mathrm{p}$..

FUCK, A.R. -1991- Aprovada a Escala de Tempo para o PE, RBG,21 (2), p.182-183. 
GAVA, A.; NASCIMENTO, D.A.; VIDAL, J.L.B.; GHIGNONE, I; OLIVEIRA, E.P. SANTIAGO FILHO, A.L.; TEIXEIRA, W. -1983- Geologia, Mapeamento Regional: Folhas SC-2425 Aracajú/Recife. Projeto RADAMBRASIL - MME, Vol. 30, p.27-252.

GHENT, E \& STOUT, M. Z. -1981- Geothermometry and Geobarometry of Plagioclase-BiotiteGarnet-Muscovite Assemblages. Contr. Min. Petr., 76, 92-97.

GOMES, J.R. de C.; GATTO, C.M.P.P.; SOUZA, G.M.C.de; LUZ, D.S.da; PIRES, J.de L. \& TEIXEIRA, W. -1981- Folhas SB.24/25, Jaguaribe/Natal. Projeto RADAMBRASIL, MME, v. 23,739 p..

GRAHAM, C.M. \& POWELL, R. -1984- A Garnet-Hornblend Geothermometer: Calibration, Testing, and Application to the Pelone Schist, Southern California. J.Met. Geol, 2, 12-31.

GUIMARÃES, I. DE P. -1989- The Petrological Evolution and Tectônic Association of the Bom Jardim Complex, Pernambuco State, NE Brazil; PhD Thesis, University of London, 424 p..

HODGES, K.V. \& SPEAR, F.S. - 1982- Geothermometry, Geobarometry and the $\mathrm{Al}_{2} \mathrm{SiO}_{5}$ Triple Point at Mt. Moosilauke, New Hampshire. Am. Min., 67, 1118-1134.

HOISCH, T.D. -1990- Empirical Calibration of Six Geobarometers for the Mineral Assemblage Quartz+Muscovite+Biotite+Plagioclase+Garnet. Contrib. Min. and Petrolog., 104, 225-234.

HOLLAND, T. \& BLUNDY, J. -1994- Non-ideal Interactions in Calcic Amphiboles and their Bearing on Amphibole-Plagioclásio Thermometry. Contrib. Min. and Petrolog., 116, p.433447.

HOLLISTER, L.S.; GRISSOM, G.C.; PETERS, E.K.; STOUWELL, H.H. \& SISSON V.B. -1987Confirmation of the Empirical Correlation of $\mathrm{Al}$ in Hornblende with Pressure of Solidification of Calc-Alkaline Plutons. Am. Min., 72, p. 231-239

JARDIM DE SÁ, E.F \& HACKSPACHER, P.C. -1980- Reconhecimento Estrutural na Borda Noroeste do Craton do São Francisco. Anais $31^{\circ}$ Cong. Bras. Geol., v.5, p. 2719-2731.

JARDIM DE SÁ, E.F. -1984- Evolução Proterozóica da Província da Borborema. Atas XI Simp. Geol. NE, p.297-316.

JARDIM DE SÁ, E.F. -1988-An Update of Pré-cambrian Geology of Northeast Brazil; Intern. Meet. Proterozoic Geol. Tectonics High-Grade Terrains, lle-lfé, Nigéria, UNESCO/IGCP, contr. vol.

JARDIM DE SÁ, E.F. -1994- A Faixa Seridó (Província Borborema, Nordeste do Brasil) e seu Significado Geodinâmico na Cadeia Brasiliana/Pan-Africana. UNB, Tese de Doutorado, Brasília, 803 p. (inédito).

JARDIM DE SÁ, E.F.; SÁ, J.M. \& MACEDO, M.H.F. -1990-Monocyclic and Policyclic Supracrustal Belts in NE Brazil: Correlations with the Pan-African Belt in West Africa. In: 
Rocci, G. \& Deschamps, M. Eds Etudes Recentes sur la Geologie de l'Africa, Nancy, CIFEG, Publ Ocas. 1990/22, p. 296-299.

JARDIM DE SÁ, E.F.; MACEDO, M.H.F.; FUCK, R.A. \& KAWASHITA, K. -1992- Terrenos Proterozóicos na Província Borborema e a Margem do Norte do Cráton São Francisco; Rev. Bras. de Geoc., v. 22, n. 4, p. 472-480.

JARDIM DE SÁ, E.F.; MEDIROS, V.C. \& AMARO, V.E. -1995- Os Cisalhamentos Brasilianos na Zona Transversal, NE do Brasil: uma Mega-Estrutura em Dominó; in: XVI Simp. Geol. do NE, Recife, SBG, Resumos, $p$.

JAZIEL, M.D. -1998- Ambiente Tectônico da Parte Oriental da Sequência SalgueiroCachoeirinha, Província Borborema. XL Cong. Bras. Geol., Belo Horizonte, Anais, SBGMG, p. 15 .

KOHN, M.J. \& SPEAR, F.S. -1989- Empirical Calibration of Geotermometer for the Assemblage Garnet + Hornblende + Plagioclase + Quartz. Am. Min., v.74, p. 77-84.

KOHN, M.J. \& SPEAR, F.S. -1990- Two New Geotermometer for Garnet Amphibolites, with Applications to Southeastern Vermont. Am. Min., V.75, p. 89-96.

KOZUCH, M.; BITTAR, S.M.B.; VAN SCHMUS, W.R. \& BRITO NEVES, B.B. -1997a- Late Mesoproterozic and Middle Neoproterozoic Magmatism im the Zona Transversal of the Borborema Province, Brazil., XVII Simp. Gel. NE, SBG, Núcleo NE, Fortaleza, CE, Bol. 15, Resumos Expandidos, p. 47-50.

KOZUCH, M.; VAN SCHMUS, W.R. \& BRITO NEVES, B.B. -1997b- Ages and Isotope Geochemistry of Two Pre-Brasiloano Magmatic Events in the Borborema Province of NE Brazil. South-American Symposiun on Isotope Geology. Brazil, p.157-160.

LAVRENT'EVA, I.V. \& PERCHUCK, L.I. -1981- Phase Correspondence in the System BiotiteGarnet: Experimental Data. Doklady Akademi Nauk, SSSR, 260, p.731-734.

LAEKE,B.E.; WOOLLEY, A.R.; ARPS, C.E.S.; BIRCH, W.D.; GILBERT,M.C.; GRICE, JID/; HAWTHORNE, F.C.; KATO, A.; KISCH, H.J.; KRIVOVICHEV, V.G.; LINTHOUT, K.; LAIRD, J.;MANDARINO, J.A.; MARESCH, W.V.; NICKEL, E.H.; ROCK, N.M.S.; SCHUMACHER, J.C.; SMITH, D.C.; STEPHENSIN, N.C.N.; UNGARETTI, L.; WHITTAKER, E.J.W. \& YOUZHI, G. -1997- Nomenclature of Anphiboles: Report of the Subcommittee on Amphiboles of International Mineralogical Association, Commission on New Minerals and Mineral Names, Am. Min., v. 82, p. 1019-1037.

LEITE, P.R.B.; BERTRAND, J.M.; LIMA, E,S, DE \& LETERRIER, J. -1996- Dados Preliminares de ldades U.Pb em Zircão para Granitóides da Faixa Pajeú-Paraíba, NE Brasil. South-American Symposium on Isotope Geology, Brasil, p. 157-160. 
LIMA, E.S. DE -1989- Evolução Tectôno-Metamórfica Durante o Proterozóico do Segmento Mediano do Domínio Estrutural Central, Nordeste Brasileiro.Tese Prof. Titular, C.T.DEGEO-UFPE, 137p.

LIMA, E.S. DE; BITTAR, S.M.B.; ACCIOLY, A.C.A.; VANNUCCI, R. \& MAZZUCHELLI, M. 1995-Reconnaissance Geochemical and Tectonic Study of the Meta-Igneous Rocks of the Central Structural Domain, Northeastern Brazil; Intern. Geol. Rewiew, v. 37, n 11, p.981991.

LISTER, G.S. \& SNOKE, A.W. -1984- S-C Mylonites. Journ. Struct. Geol., 6 (6), p. 617-638.

MARIANO, G. -1989- Magma Mixing Origin of a Potassic Calc-Alcaline Pluton: the Itaporanga Batholith, State of Paraiba, Northeastern Brazil, M.S. University of Georgia, 180p.

McKENZIE, D., 1978. Some remarks on the development of sedimentary basins. Earth and Planetary Science Letters, 40, 25-32.

MARQUES, V.J. \& SOUZA, E.C.de -1985- Projeto Cachoeirinha: Relatório Final. v. 5, Apêndice, Estudo Petroquímico Preliminares sobre as Rochas do Projeto CachoeirinhaIndicações Geológicas e Temas para Debate, MME, Convênio DNPM/CPRM, 11 p. (anexos)

MEDEIROS, V.C. DE -1995- Sensoriamento Remoto e Petrologia de Granitóides Brasilianos no Dominio da Zona Transversal, Nordeste do Brasil. Dissertaçăo de Mestrado, Centro de Tecnologia, DEGEO/UFPE, 145p.

PASCHIER,C.W.; TROUW, R.A.J; ZWART, H.T. \& VISSERS, R.L.M. -1992- Porphyroclast Rotation.: eppur si mouve?. Jour. Meta. geol.,10, 283-294.

PERCHUK, L.L. -1991- Progress in Metamorphic and Magmatic Petrology . ed. Press Syndicate of the University of Cambridge, New York USA, $503 \mathrm{p}$.

PLYUSNINA, L.P. -1982- Geothermometry and Geobarometry of Plagioclase-Hornblend Bearing Assemblages. Contr. Min. Petr. 80, 140-146.

ROBINSON, P.; SCHUMACHER, J.C. \& SPEAR, E.S. -1982- Formulation of Electron Probe Analyses. In: Verblen DR. Ribbr PH (eds) Amphiboles Petrology and Experimental Phase Relations. Min. Soc. Am, 9, p.6-9.

ROYDEN, L.; SCLATER, J.G. \& VON HERZEN, R.P. -1980- Continental margin subsidence and heat flow: important parameters in formation of petroleum hydrocarbons. Americam Association of Petroleum Geologists, 64, 173-187.

ROLLINSON, H. -1993- Using Geochemical Data: Evaluetion, Presentation, interpretation.Ed. Longmam Scientific \& Technical, England,350p..

SADOWSKI, G.R. -1972- Considerações Preliminares sobre a Geologia do Batólito da Baixa Verde-PE, Dissertação de Mestrado, Inst. Geoc. da Universidade de São Paulo, 33p. 
SANTOS, E.J. DOS -1977- Sintese da Geologia Precambriana da Folha Arco Verde. Atas, 15 Simp. Geol, Nordeste, b. 13, p. 322-323.

SANTOS, E.J. DOS -1993- O Episódio Magmático de 1,1-0,9 Ga do Domínio Extremo Nordeste; in: VIil Simp.Geol. NE, Campina Grande, Atas, SBG, v. 6, p. 225-245.

SANTOS E.J. DOS -1995- O Complexo Granítico Lagoas das Pedras: Acresção e Colisão na Região de Floresta (Pernambuco), Província Borborema. Tese de Doutorado, IG-USP, 220p. (inédito).

SANTOS, E.J. DOS-1996- Ensaio Preliminar sobre Terrenos e Tecônica Acrescionária na Província Borborema. $39^{\circ}$ Cong. Bras. Geol., Salvador, SBG, Anais, v.6, p.47-50.

SANTOS, E. J. DOS; COUTINHO, M. G. DA N.; COSTA, M. P. DE A. \& RAMALHO, R. -1984A Região de Dobramentos Nordeste e a Bacia do Parnaiba, Incluindo o Craton do São Luís e as Bacias Marginais. IN: Schobbenhaus, C.; Campos D.de A.; Derze, G.R. \& Asmus, H.E. (1984) Geologia do Brasil: texto explicativo do mapa geológico do Brasil e da área oceânica adjacente incluindo depósitos minerais, escala 1:2. 500.000; cap. 4, p. 131195.

SANTOS, E.J. DOS \& BRITO NEVES, B.B. DE -1993- Petrogenetic and Tectonic Setting of Lagoa das Pedras Magmatism, Floresta, State of Pernambuco, Northeast Brazil. Anais Acad. Bras. Ciênc., 65: 131-139.

SIAL, A.N. -1986- Granite-Types in Northeast Brazil: Current Knowledge. Rev. Bras. Geoc., v. 16, n. 1, p.54-72

SIAL, A.N. -1987- Grantic Rocks in Northeast Brazil; Int. Symp. Granites Assoc. Mineraliz., Ext. Abst., p.61-69.

SIAL, A.N. -1993- Contrasting Metaluminous Magmatic Epidote-Bearing Granodiorites and Tonalites in a Precambrian Foldbelt, NE Brazil. IX Semana de Geoquímica e II Cong. Geoquímica dos Paises de Língua Portuguesa, Porto, Memóris, n.3, p.169-172.

SIAL, A.N.; BRITO NEVES, B.B. DE; BEURLEN,H.; MELO, P.G. DE \& PESSÓA, R.R. -1983Projeto Extremo Oeste de Pernambuco: Quadriculas Salgueiro e Partes de Chorrocho e Parnamirim - PE; Relatório Final, Recife, CT - UFPE, 51 p..

SIAL, A.N.; FERREIRA, V.P. \& MARIANO, G. -1990- Granitbides do Domínio Estrutural Central, NE do Brasil; in: XXXVI Cong. Bras. Geol., Natal, Roteiro de Excursão, SBG, 45 p. $87-92$.

SIAL, A.N. \& FERREIRA, V.P. -1991- Granitóides Calcio-Alcalinos com Epidoto igneo nos Cinturões Seridó e Cachoeirinha-Salgueiro, Nordeste do Brazil: Aspectos Geoquímicos, Isótopos Estáveis, Temperaturas e Profundidades de Solidificação. Cong. Bras. Geoquím., p.300-303. 
SIAL, A.N. \& FERREIRA, V.P. -1988- Brasilian Age Peralkaline Plutonic Rocks of the Central Structural Domain, Northeast Brazil. Rendicontti della Societa Italiana di Mineralogia e Petrologia, 43 (2), p. 307-342.

SIAL, A.N.; MARIANO, G. \& FERREIRA, V.P. -1989- Síntese da Geoquímica dos Elementos Terras Raras em Granitóides do Nordeste do Brasil, in: FORMOSO, M.L.L., NARDI, L.V.S. \& HARTMANN, L.A. (1989) Geoquímica dos Elementos Terras Raras no Brasil; Rio de Janeiro, CPRM/DNPM, Soc. Bras. de Geoq., cap. 5, p.83-95.

SILVA FILHO, A.F. DA -1989- Shoshonitic and Ultrapotássic Intrusive Suites in the Pianco-Alto Brígida Belt, Pernambuco State, Brazil; Thesis PhD, University of London, 422 p..

SILVA FILHO, A.F. DA; GUIMARÃES, I.P. \& THOMPSON, R.N. -1993- Shoshonitic and Ultrapotassic Proterozóic Intrusive Suites in the Cachoeirinha-Salgueiro Belt, NE Brazil: a Transitional from Collisional to Post-Collisional Magmatism. Precamb. Res.,

SILVA FILHO, M.A. DE \& CARDOSO, J.J.R -1985- Projeto Cachoeirinha: Relatório Final. v. 15, MME, Convênio DNPM/CPRM (texto, anexos e apêndice).

SPEAR, F.S. -1981- Amphibole-Plagioclase Equilibria: an Empirical Model for the Relation Albite + Tremolite $=$ Edenite +4 Quartz. Contr. Min. Petr., v. 77, p. 355-364.

SPEAR, F.S. -1995- Metamorphic phase equilibria and pressure-temperature-time paths. Mineralogical Society of America, Monograph Series, Second Edition, 799 pp.

SORENSEN, S.S. -1994- Petrology of Basement Rocks of the california Continental Borderland and Los Angeles Basin. PhD Dissertation, UCLA, 423 p.

THOMPSON, A.B. \& RIDLEY; J.R. -1987- Pressure-Tempeture-Time (P-T-t) Histories of Orogenic Belts. Phil. Trans. R. Soc. Lond., A 321, p. 27-45.

VAN SCHMUS, W.R.; BRITO NEVES, B.B. \& HACKSPACHER, P. -1994- Identification of Lithospheric Domains in NE, Brazil and Their Relevance to the Ancestry and Assembly of Western Gondwana. Intern. Symp. Phys Chem. Upper Mantle, Ext Abst, p. 79-81.

VAN SCHMUS, W.R., BRITO NEVES, B.B. DE \& HACKSPACHER, P. \& BABINSK, M. -1995$\mathrm{U}-\mathrm{Pb}$ and Sm-Nd Geochronologic Studies of Eatern Borborema Province, Northeastern Brazil: Initial Conclusions; Jorn of South Am. Earth Scien, v. 8, n: 3/4, p.267-288.

VAUCHEZ, A.; AMARO, V.; ARCHANJO, C.; ARTHAUD, M.; BOUCHEZ, J.L.; CABY, R.; CORSINI, M.; EGYDIO-SILVA, M. JARDIM DE SÁ, E.F.; NEVES, S.P.; SÁ, J.M. \& SIAL, A.N. - 1992- The Borborema Shear Zone System: a Tectonic Model, Anais $37^{\circ}$ Cong. Bras. Geol., SBG/SP, São Paulo, SP, B. Resumos Expandidos, v. 2, p. 371-372.

VEIGA JUNIOR, J.P. \& FERREIRA, C.A.-1990- Afogados da Ingazeira, Folha SC.24-Z-C-VI. PLGB, Texto Expl. e Mapas, DNPM/CPRM, 121 p.. 
ZWART, H.J. -1962-On the Chronological Sucession of Folding and Metamorphism in the Central Pyrenees. Geol. Rdsch., 50, p. 203-218. 
TABELAS 


\begin{tabular}{|l|l|l|l|l|l|l|}
\hline \multicolumn{1}{|c|}{ Litologia/Localização } & Unidade & Rb/Sr Ga & $\mathbf{R}_{\mathbf{0}}$ & $\varepsilon_{\mathrm{Nd}}(1.0)$ & $\varepsilon_{\mathrm{Nd}}(2.1)$ & TDM (1.0) Ga \\
\hline São José da Caiana ${ }^{\star 1}$ (NW ZC Boqueirão dos Cochos) & & & & -16.76 & -1.18 & 2.40 \\
\hline biotita-gnaisse bandado Serra Talhada $^{\star 2}$ & CST & $2.10^{i}$ & & & \\
\hline ortognaisses migmatíticos $^{\star 3}$ & CF & $\begin{array}{l}2.70 \pm 0.10^{i} \\
1.99 \pm 0.01^{i}\end{array}$ & $\begin{array}{l}0.701 \\
0.720\end{array}$ & & \\
\hline ortognaisse grosso ban-dado (N Quixaba) & & $2.60 \pm 0.13^{\circ}$ & & & & \\
\hline
\end{tabular}

${ }^{\star 1}$ Kozuck, inédito; ${ }^{* 2}$ Brito Neves, inédito; ${ }^{* 3}$ Lima et al, 1986

CST - Complexo Serra Talhada; CF - Complexo Floresta; ${ }^{\prime}$ - isócrona; ${ }^{\circ}$ - convencional

TABELA 1 -

Dados geocronológicos do embasamento na área do presente trabalho e adjacências 


\begin{tabular}{|c|c|c|c|c|c|c|c|c|c|}
\hline Litologia/Localizaçăo & Unidade & $\mathrm{U} / \mathrm{Pb} \mathrm{Ma}$ & $\mathrm{Rb} / \mathrm{SrMa}$ & $\mathbf{R}_{0}$ & ${ }^{147} \mathrm{Sm} /{ }^{144} \mathrm{Nd}$ & $\varepsilon_{\mathrm{Nd}}(0.6)$ & $\varepsilon_{\mathrm{Nd}}(0.75)$ & $\varepsilon_{\mathrm{Nd}}(\mathbf{1 . 0})$ & TDM(1.0)Ma \\
\hline ST-AC-78 (metagabro) ${ }^{ \pm 0}$ & CRG & & & & $0.1602 *$ & 0.27 & & 2.61 & 1516 \\
\hline ST-AC- 85 (metagabro) ${ }^{\star 0}$ & CRG & & & & $0.1592 *$ & 0.79 & & 2.72 & 1424 \\
\hline ST-AC-86 (metagabro) ${ }^{\star 0}$ & CRG & & & & 0.1673 * & 1.00 & & 2.51 & 1531 \\
\hline ST-AC-134 (metagabro) ${ }^{* 0}$ & CRG & & & & $0.1576^{*}$ & 2.02 & & 4.04 & 1234 \\
\hline metagabro W Poço do Cachorro*1 & CRG & & & & * & 1.61 & 2.41 & 3.76 & 1260 \\
\hline ST-E-206.4 (granada-anfibolito) ${ }^{\star 0}$ & CRG & & & & $0.1650 *$ & -3.59 & & -1.96 & 2239 \\
\hline ST-S-4 (mvi) ${ }^{00}$ & CRG & & & & $0.1765^{*}$ & -5.63 & & -1.96 & 3294 \\
\hline ST-AC-204.1 (mvb) $\star^{0}$ & CRG & & & & 0.1746 * & -3.28 & & -2.15 & 2605 \\
\hline metagrauvaca NW Manaira ${ }^{* 1}$ & CRG & & & & & -3.92 & -2.52 & -0.19 & 1514 \\
\hline ST-S- 5 (metassedimento) ${ }^{* 0}$ & CRG & & & & 0.1231 & -9.92 & & -6.14 & 2024 \\
\hline $\begin{array}{r}\text { metaturbidito Barragem do Saco*1 } \\
\text { metasiltito } \\
\text { metarenito } \\
\end{array}$ & CRG & & & & & \begin{tabular}{|l|}
-8.49 \\
-6.11 \\
\end{tabular} & & \begin{tabular}{|l|}
-3.45 \\
-0.57 \\
\end{tabular} & \begin{tabular}{|l|}
1831 \\
1559 \\
\end{tabular} \\
\hline ST-S-38.9 (metariolito) ${ }^{* 0}$ & CRG & & & & $0.1318^{*}$ & -5.43 & & -1.26 & 1742 \\
\hline ST-AC-192.2 (metandesito) ${ }^{* 0}$ & CRG & & & & $0.1518^{*}$ & 1.89 & & 4.20 & 1193 \\
\hline tufo riolítico Piaus ${ }^{{ }^{2}}$ & CRG & 970 & & & 0.10312 & -10.1 & & -5.0 & 1770 \\
\hline andesito Serra da Pinheira ${ }^{{ }^{2}}$ & CRG & 980 & & & 0.10082 & -5.2 & & -1.7 & 1660 \\
\hline tufo riolitico Manaira ${ }^{{ }^{2}}$ & CRG & 970 & & & 0.12732 & -5.0 & & 0.0 & 1560 \\
\hline tufo riolitico Fazenda Mocambo ${ }^{2}$ & CRG & $637 \pm 21$ & & & 0.11007 & -3.2 & & & 1340 \\
\hline metavulcânica sul São José do Bonfim ${ }^{* 1}$ & CRG & $985^{* 4}$ & & & & & & & \\
\hline metariolito rosa Piaus ${ }^{* 1}$ & CRG & 930 & & & & & & -4.06 & 1773 \\
\hline metariolito rosa porfiriticoPiaus ${ }^{\star 1}$ & CRG & & & & & & 3.69 & & 2075 \\
\hline metariolito Piaus $\star^{1} \star^{4}$ & CRG & $1070 \pm 30$ & $950 \pm 30$ & 0.711 & & & & & \\
\hline metatufo NW Manaíra*4 & CRG & $1126 \pm 16$ & & & & -5.23 & & -1.67 & 1665 \\
\hline metavulcânica ácida NW Manaíra ${ }^{\star 1}$ & CRG & 1060 & & & & -4.96 & & -0.04 & 1561 \\
\hline andesito Serra da Pinheira ${ }^{* 1}$ & CRG & 930 & & & & & & & \\
\hline riolito Serra da Pinheira ${ }^{* 1}$ & CRG & & & & & -6.35 & & -1.43 & 1494 \\
\hline feldsito Serra da Pinheira* ${ }^{*}$ & CRG & & & & & -5.23 & & -1.67 & 1665 \\
\hline metavulcânica félsica NW Maniira ${ }^{* 1}$ & CRG & & & & & -6.70 & -5.03 & -2.40 & 1596 \\
\hline metatufo féssico Carnaúba dos Pinheiros ${ }^{* 1}$ & CRG & $1011 \pm 44$ & & & & & & -3 & 1330 \\
\hline metadacito Carnaúba dos Pinheiros ${ }^{\star 1}$ & CRG & $975+19$ & & & & & & -1 & 1300 \\
\hline sheet granitico ${ }^{1}$ Fazenda Mocambo ${ }^{*}$ & CRG & 746 & & & & -3.23 & & -1.56 & 1339 \\
\hline sheet granítico ${ }^{2}$ Fazenda Mocambo ${ }^{\star 1}$ & CRG & $\begin{array}{l}600(1)^{\star *} \\
750(2) \\
1000(3)\end{array}$ & & & & & & & \\
\hline sheet riolítico sul de Catingueira* ${ }^{* 1}$ & CRG & \pm 750 & & & & & & & \\
\hline riolito porfirítico Baixa Grande ${ }^{{ }^{2}}$ & is & 750 & & & 0.12803 & -3.4 & & & 1510 \\
\hline Sheet granitico Santana dos Garrotes ${ }^{* 1}$ & Cach & & & & & -2.48 & & 2.57 & 1215 \\
\hline dacito Santana dos Garrotes ${ }^{*^{1}}$ & Cach & 810 & & & & -1.4 & & & 1300 \\
\hline metadacito pórfiro SW José do Bonfim ${ }^{*^{1}}$ & Cach & 814 & & & & & & & \\
\hline metadacito sul Santana dos Garrotes ${ }^{* 1}$ & Cach & $\begin{array}{l}788(1)^{\star \star} \\
1305(2)\end{array}$ & & & & -1.35 & & 0.02 & 1305 \\
\hline metavulcânica ácida Nova Olinda ${ }^{1}$ & Cach & & & & & -7.0 & & & 1410 \\
\hline andesito Serra do Olho D'Agua *1 & Cach. & & & & & 1.83 & & 5.68 & 1009 \\
\hline metafélsica Santana da Mangueira ${ }^{{ }^{1}}$ & Cach & & & & & -33.9 & & & 2800 \\
\hline xisto verde Santana dos Garrotes ${ }^{* 1}$ & Cach & & & & & -2.11 & & 3.39 & 1263 \\
\hline filito cinza Santana da Mangueira* ${ }^{* 1}$ & Cach & & & & & -33.87 & & & 2.805 \\
\hline sill-gr-bt xisto leste Piancó ${ }^{* 1}$ & Cach & & & & & & & & 1280 \\
\hline
\end{tabular}

${ }^{* 1}$ Kozuck e/ou Van Schmus, inédito (dados U/Pb e Sm/Nd); ${ }^{2}$ Kozuck, 1997a e 1997b; ${ }^{3}$ Brito Neves, inédito (dados Rb/Sr); ${ }^{4}$ Brito Neves et al, 1990; ${ }^{0}$ Kozuck et al, inédito;

* alto ${ }_{147} \mathrm{Sm} /{ }_{144} \mathrm{Nd}$; ** mais de uma população de zircões; CRG - Complexo Riacho Gravatá; Cach. - Complexo Cacoeirinha; CIS - Complexo irajaí-Sertânia 


\begin{tabular}{|c|c|c|c|c|c|c|c|}
\hline Litologia/Localização & Intrusivo & U/Pb Ma & $\mathrm{Rb} / \mathrm{S} \mathbf{r M a}$ & $\mathbf{R}_{\mathbf{0}}$ & ArlAr Ma & $\varepsilon_{N d}(0.6)$ & TDM $(1.0) \mathrm{Ma}$ \\
\hline granito Emas ${ }^{\star 1}$ & C. Cachoeirinha. & & & & & -1.99 & 1300 \\
\hline granito Itaporanga $1 * 1 * 2$ & C. Cachoeirinha. & & $551 \pm 70^{i}$ & 0.707 & & -9.0 & 1644 \\
\hline granito Itaporanga $2^{* 3} \star^{4}$ & C. Cachoeirinha. & & $620+22^{i}$ & 0.706 & $\begin{array}{l}584 \pm 6_{\mathrm{hb}} \\
544 \pm 6_{\mathrm{bt}}\end{array}$ & & \\
\hline granito Conceição1*i & C. Cachoeirinha.. & $620 \pm 10$ & & & & & \\
\hline granito Conceição $2^{* 3 * 4}$ & C. Cachoeirinha.. & & $580^{i}$ & & $\begin{array}{l}618 \pm 27_{\mathrm{hb}} \\
603 \pm 17_{\mathrm{bt}}\end{array}$ & & \\
\hline granito Conceição $3^{* * 2}$ & C. Cachoeirinha.. & & & & $625(\mathrm{~K} / \mathrm{Ar})$ & -1.23 & 1.23 \\
\hline granito Nova Olinda*1 & c. Cachoeirinha.. & & & & & -2.03 & 1412 \\
\hline sienito Catingueira ${ }^{* 1}$ & C. Cachoeirinha. & & & & & -15.65 & $2397 ?$ \\
\hline gabro Alto Vermelho ${ }^{* 5}$ & C. Cachoeirinha.. & & & & & -2.45 & $1473^{*}$ \\
\hline
\end{tabular}

${ }^{\star 1}$ Kozuck elou Van Schmus, inédito (dados U/Pb e Sm/Nd); *2 Brito Neves, inédito (dados Rb/Sr e K/Ar); ${ }^{3}$ Dallemeyer, et al, 1987 (dados Ar/Ar); ${ }^{* 4}$ McMurry et al, 1987 (dados Rb/Sr); ${ }^{* 5}$ Kozuck, 1997a e 1997b

${ }^{*}$ alto ${ }_{147} \mathrm{Sm} /{ }_{144} \mathrm{Nd} ;{ }^{i}$ - isócrona

\section{TABELA 3 -}

Dados geocronológicos dos granitóides da área do presente trabalho e adjacências, localizados a norte da Zona de Cisalhamento Serra do Caboclo. 


\begin{tabular}{|c|c|c|c|c|c|c|}
\hline Litologia/Localização & Intrusivo & $\mathrm{U} / \mathrm{Pb} \mathrm{Ma}$ & $\mathrm{Rb} / \mathrm{Sr} \mathrm{Ma}$ & ${ }^{147} \mathrm{Sm} /{ }^{144} \mathrm{Nd}$ & $\varepsilon_{\text {Nd }}(0.6)$ & $\operatorname{TDM}(1.0) \mathrm{Ma}$ \\
\hline granitóide Itapetim (Brejinho) ${ }^{\star 1}$ & CIS & & & & $\begin{array}{l}-3.52 \\
-3.48 \\
\end{array}$ & $\begin{array}{r}1401 \\
1385 \\
\end{array}$ \\
\hline granodiorito milonítico S. José do Bonfim (sul de Patos) ${ }^{* 1}$ & CRG & 681 & & & & \\
\hline granitóide Princesa |zabe|*1 & ATTN & & & & -9.25 & 1454 \\
\hline granitóde Tavares $\star^{\star^{4}} *^{3}$ & ATTN & & $650^{\circ}$ & & & \\
\hline granitóide Solidäo (Fazenda Areias) $\star^{2}$ & Cis & 570 & & 0.09611 & -15.5 & 2140 \\
\hline granodiorito Serra Talhada/ Santa Rita ${ }^{* 1}$ & CRG & & & & -18.44 & 2326 \\
\hline granodiorito $\mathrm{N}$ de Santa Rita*1 & CRG & & & & -15.95 & 2404 \\
\hline sieno-granito Teixeira/Taperoá*1 & ATTN & & & & -21.13 & 2036 \\
\hline granitóide Palmeiras ${ }^{2^{2}}$ & ATTN & 570 & & 0.10964 & $\begin{array}{l}-14.25 \\
-14.08 \\
\end{array}$ & $\begin{array}{l}2167 \\
2153 \\
\end{array}$ \\
\hline dique alcalino Princesa $\mid$ Isabel $^{\star 1}$ & ATTN & & & & -12.11 & 1892 \\
\hline sienito Triunfo $*^{1} *^{4}$ & ATTN & & 580 & & -16.35 & 2439 \\
\hline dique sienito NW Manaira* & CRG & & & & -17.8 & 2521 \\
\hline dique alcalino E de SãoJosé $\star^{\star 1}$ & ATTN & & & & -12.11 & 1892 \\
\hline ST-AC-202.4 (microsienito) $\star^{0}$ & CRG & & & 0.1200 & -14.94 & 2404 \\
\hline ST-S-41.3 (dique felsico) ${ }^{* 0}$ & CRG & & & 0.1241 & -14.69 & 2467 \\
\hline gabro Jabitacá $\dot{*}^{2}$ & CIS & 600 & & * & -3.6 & \\
\hline
\end{tabular}

${ }^{*}{ }^{0}$ Kozuck et al, inédito; ${ }^{\star 1}$ Kozuck e/ou Van Schmus, inédito (dados U/Pb e Sm/Nd) : ${ }^{2}$ Kozuck, 1997a e 1997b; ${ }^{3}$ Brito Neves, inédito (dados Rb/Sr);

*4 Sial \& Ferreira, 1990 (dados Rb-Sr)

* alto ${ }_{147} \mathrm{Sm} /{ }_{144} \mathrm{Nd}$; CRG - Complexo Riacho Gravatá; Cach. - Complexo Cacoeirinha; CIS - Complexo Irajaí-Sertânia; ATTN - Alto Teixeira-Terra Nova

\section{TABELA 4 -}

Dados geocronológicos dos granitóides da área do presente trabalho e adjacências, localizados a sul da Zona de Cisalhamento Serra do Caboclo 


\begin{tabular}{|c|c|c|c|c|c|c|c|c|}
\hline Litologia/Localização & $\mathrm{U} / \mathrm{Pb} \mathrm{Ma}$ & Rb/Sr Ma & $\mathbf{R}_{\mathbf{0}}$ & ${ }^{147} \mathrm{Sm} i^{144} \mathrm{Nd}$ & $\varepsilon_{\mathrm{Nd}}(0.6)$ & $\varepsilon_{N d}(1.0)$ & $\varepsilon_{\mathrm{Nd}}(2.1)$ & TDM(1.0)Ma \\
\hline gnaisse Serra Talhada ${ }^{{ }^{1}}$ & 960 & $1007 \pm 188^{\circ}$ & & 0.1289 & -3.5 & 1.7 & & 1400 \\
\hline gnaisse Fazenda do Arroz ${ }^{* 1}$ & 920 & & & 0.1348 & -4.3 & -0.3 & & 1670 \\
\hline gnaisse Ambó ${ }^{1}$ & 950 & & & 0.1382 & -4.8 & -1.1 & & 1780 \\
\hline $\begin{array}{l}\text { gnaisse Lagoa dos Guedes } \\
\text { (Imaculada/Palmeiras) }^{{ }^{1}}\end{array}$ & 960 & $970^{\mathrm{c} i}$ & & 0.1208 & $\begin{array}{l}-5.8 \\
4.98 \\
\end{array}$ & $\begin{array}{l}-1.0 \\
-0.13 \\
\end{array}$ & +9.64 & $\begin{array}{l}1640 \\
1574 \\
\end{array}$ \\
\hline gnaisse Queimadas ${ }^{* 1}$ & 940 & & & 0.1296 & -2.5 & 1.0 & & 1440 \\
\hline anfibólio gnaisse (Afogados) $)^{*^{1}}$ & 1000 & & & 0.0883 & -4.8 & -1.1 & & 1780 \\
\hline gnaisse Serra Das Vassouras ${ }^{\star^{2}}$ & $925 \pm 8$ & & & & $\begin{array}{r}-4.9 \\
-4.6\end{array}$ & & & $\begin{array}{l}1920 \\
1680\end{array}$ \\
\hline gnaisse Piedade do Ouro (Norte Brejinho) ${ }^{\star 2 \star 3}$ & & $1012+38^{\prime}$ & & & -5.30 & -0.40 & & 1594 \\
\hline augen-gnaisse Desterro ${ }^{* 3}$ & & $970^{\circ}$ & & & & & & \\
\hline gnaisse Placas de Piedade (Sul Teixeira) ${ }^{3}$ & & $945 \pm 31^{\circ}$ & & & & & & \\
\hline ortognaisse Fazenda Degredo (Brejinho) ${ }^{* 3}$ & & $970^{\text {ci }}$ & & & & & & \\
\hline ortognaisse Agua Branca $*^{2} *^{3}$ & & $963+14$ cí & & & -3.65 & -0.13 & & 1707 \\
\hline ortognaisse Fazenda do Arroz $\star^{2} \star^{3}$ & 960 & $970^{\circ i 1}$ & & & -4.28 & -0.30 & & 1672 \\
\hline ortognaisse Imaculada $\star^{2} \star^{3}$ & & $970^{\mathrm{c} i \mathrm{i}}$ & & & $\begin{array}{l}-5.77 \\
-5.81 \\
-3.79 \\
\end{array}$ & $\begin{array}{l}-0.94 \\
-0.96 \\
-0.08\end{array}$ & & $\begin{array}{l}1643 \\
1644 \\
1679 \\
\end{array}$ \\
\hline ortognaisse Lagoa do Vicente $\star^{2} \star^{3}$ & & $970^{\text {chi }}$ & & & \begin{tabular}{|l}
-3.8 \\
-3.07
\end{tabular} & $\mid \begin{array}{l}-0.1 \\
0.71\end{array}$ & 8.34 & $\begin{array}{l}1680 \\
1590\end{array}$ \\
\hline ortognaisse Belém *3 & & $970^{\circ}$ & & & & & & \\
\hline augen-gnaisse Faz. Espuma (Agua Branca) $\star^{3}$ & & $993 \pm 30^{\circ}$ & & & & & & \\
\hline $\begin{array}{l}\text { ortognaisse bandado Açúde dos Franciscos } \\
\text { (Tavares/Princesa Izabel) }{ }^{* 3}\end{array}$ & & $1063 \pm 45^{\circ}$ & & & & & & \\
\hline ortognaisse bandado Bom Jesus $\star^{3}$. & & $992 \pm 34^{\circ}$ & & & & & & \\
\hline ortognaisse São Joaquim (Sul de Tabira) ${ }^{\star^{2}}$ & 970 & & & & & & & \\
\hline ortognaisse Santo Aleixo $*^{3}$ & & $1004 \pm 34^{c}$ & & & & & & \\
\hline gnaisse tonalitico (Este de Tavares) $\star^{2} \star^{3}$ & $949 \pm 5$ & $991 \pm 34^{\circ}$ & & & -2.47 & 0.98 & & 1440 \\
\hline ortognaisse Vassouras ${ }^{\star^{4}}$ & 960 & $937 \pm 14^{1 / 0}$ & 0.707 & & $-4.9--4.6$ & & & $1970-1680$ \\
\hline granitóide Recanto $\star^{4}$ & $999 \pm 50$ & & & & & & & \\
\hline ortognaisse pórfiro tipo Recanto ${ }^{* 1}$ & $1037 \pm 30$ & & & & & & & 1610 \\
\hline
\end{tabular}

${ }^{*}$ Kozuck, 1997a e 1997b; *2 Kozuck e/ou Van Schmus, inédito (dados U/Pb e Sm/Nd); ${ }^{3}$ Brito Neves, inédito (dados Rb/Sr); Brito Neves, 1995

${ }^{i}$ - isócrona; ${ }^{\circ}$ - idade convencional

TABELA 5 -

Dados Geocronológicos dos ortognaisses Cariris Velhos do Alto Teixeira-Terra Nova na área do presente trabalho e adjacências. 


\begin{tabular}{|c|c|c|c|c|}
\hline Complexo & Amêndoa & Metassedimentos & $\begin{array}{l}\text { Metavulcânica ácida a } \\
\text { intermediária }\end{array}$ & $\begin{array}{l}\text { Metavulcânica básica (1) e ultrabásicas } \\
\text { (2) }\end{array}$ \\
\hline $\begin{array}{l}\text { Riacho } \\
\text { Gravatá }\end{array}$ & $\begin{array}{l}\text { Serra da } \\
\text { Pinheira } \\
\text { Manaira- } \\
\text { Santana da } \\
\text { Mangueira }\end{array}$ & $\begin{array}{l}\text { quartzo + mica branca }+ \text { biotita } \pm \\
\text { granada } \pm \text { plagioclásio } \pm \text { clorita }+ \\
\text { minerais opacos }\end{array}$ & $\begin{array}{l}\text { plagioclásio }+ \text { k-feldspato }+ \text { biotita } \pm \\
\text { muscovita } \pm \text { anfibólio } \pm \text { clorita }+ \\
\text { minerais opacos }\end{array}$ & $\begin{array}{l}\text { (1)anfibólio + plagioclásio }+ \text { quartzo }+ \text { biotita }+ \\
\text { minerais opacos }+ \text { titânita }+ \text { epidoto } \pm \text { clorita } \\
\text { (2)anfibólio } \pm \text { talco } \pm \text { clorita } \pm \text { biotita }+ \text { minerais } \\
\text { opacos }\end{array}$ \\
\hline $\begin{array}{l}\text { Riacho } \\
\text { Gravatá }\end{array}$ & $\begin{array}{l}\text { Serra da } \\
\text { Pinheira } \\
\text { Serra } \\
\text { Talhada- } \\
\text { Tabuleiro }\end{array}$ & $\begin{array}{l}\text { a norte: quartzo } \pm \text { plagioclásio }+ \\
\text { biotita + muscovita } \pm \text { granada }+ \\
\text { turmalina + minerais opacos } \\
\text { a sul: quartzo } \pm \text { plagioclásio } \pm \\
\text { muscovita + biotita } \pm \text { granada } \pm \\
\text { sillimanita + turnalina + minerais } \\
\text { opacos }\end{array}$ & $\begin{array}{l}\text { a norte: quartzo } \pm \text { plagioclásio + biotita } \\
\pm \text { muscovita } \pm \text { granada }+ \text { minerais } \\
\text { opacos } \\
\text { a sul: quartzo } \pm \text { plagioclásio } \pm \\
\text { muscovita + biotita } \pm \text { granada }+ \text { minerais } \\
\text { opacos }\end{array}$ & $\begin{array}{l}\text { a norte: anfibólio + plagioclásio } \pm \text { granada }+ \\
\text { quartzo + titanita + minerais opacos + epidoto } \pm \\
\text { biotita } \\
\text { a sul: anfibólio + plagioclásio } \pm \text { granada + } \\
\text { quartzo + titanita + minerais opacos + epidoto } \pm \\
\text { biotita }\end{array}$ \\
\hline $\begin{array}{l}\text { Riacho } \\
\text { Gravatá }\end{array}$ & $\begin{array}{l}\text { Macacos- } \\
\text { Piaus }\end{array}$ & \begin{tabular}{|l|} 
muscovita + biotita + quartzo \pm \\
granada \pm plagioclásio \\
minerais opacos + turmalina
\end{tabular} & $\begin{array}{l}\text { plagioclásio }+ \text { quartzo }+ \text { biotita }+ \\
\text { muscovita } \pm \text { granada }+ \text { minerais opacos }\end{array}$ & $\begin{array}{l}\text { anfibólio + quartzo + plagioclásio } \pm \text { granada }+ \\
\text { minerais opacos }+ \text { epidoto }\end{array}$ \\
\hline $\begin{array}{l}\text { Riacho } \\
\text { Gravatá }\end{array}$ & $\begin{array}{l}\text { Serra do } \\
\text { Mocambo } \\
\text { Norte }\end{array}$ & $\begin{array}{l}\text { clorita + mica branca + biotita + } \\
\text { quartzo + turmalina + minerais } \\
\text { opacos }\end{array}$ & $\begin{array}{l}\text { feldspato }+ \text { biotita } \pm \text { muscovita },+ \\
\text { quartzo } \pm \text { granada }+ \text { minerais opacos }\end{array}$ & $\begin{array}{l}\text { anfibólio + feldspato }+ \text { quartzo }+ \text { epidoto }+ \\
\text { minerais opacos }\end{array}$ \\
\hline $\begin{array}{l}\text { Riacho } \\
\text { Gravatá }\end{array}$ & $\begin{array}{l}\text { Serra do } \\
\text { Mocambo } \\
\text { Sul }\end{array}$ & $\begin{array}{l}\text { quartzo } \pm \text { plagioclasio } \pm \text { granada } \\
+ \text { biotita }+ \text { muscovita }+ \text { minerais } \\
\text { opacos + turmalina }\end{array}$ & $\begin{array}{l}\text { feldspato }+ \text { biotita } \pm \text { granada } \pm \\
\text { muscovita } \pm \text { anfibólio }+ \text { minerais opacos }\end{array}$ & $\begin{array}{l}\text { anfibólio + feldspato }+ \text { quarzto } \pm \text { granada }+ \\
\text { epidoto + minerais opacos }\end{array}$ \\
\hline Cachoeirinha & $\begin{array}{l}\text { Santana do } \\
\text { Garrotes }\end{array}$ & $\begin{array}{l}\text { quartzo + biotita }+ \text { muscovita }+ \\
\text { clorita } \pm \text { plagioclásio } \pm \text { granada }+ \\
\text { minerais opacos }+ \text { turmalina }\end{array}$ & $\begin{array}{l}\text { feldspatos }+ \text { biotita }+ \text { quartzo } \pm \\
\text { muscovita }+ \text { minerais opacos }\end{array}$ & $\begin{array}{l}\text { anfibólio + feldspato }+ \text { quarzto }+ \text { epidoto }+ \\
\text { minerais opacos }\end{array}$ \\
\hline Cachoeirinha & Piancó & $\begin{array}{l}\text { núcleo: plagioclásio + quartzo }+ \\
\text { biotita } \pm \text { muscovita } \pm \text { granada } \pm \\
\text { estaurolita } \pm \text { sillimanita }+ \\
\text { minerais opacos } \pm \text { turmalina } \\
\text { flancos: plagioclásio + quartzo }+ \\
\text { biotita }+ \text { muscovita } \pm \text { granada } \pm \\
\text { clorita }+ \text { minerais opacos } \pm \\
\text { turmalina }\end{array}$ & $\begin{array}{l}\text { núcleo: plagioclásio + } k \text {-feldspato }+ \\
\text { quartzo + biotita } \pm \text { muscovita + minerais } \\
\text { opacos } \\
\text { flancos: plagioclásio + quartzo + } k- \\
\text { feldspato + quartzo + biotita } \pm \text { muscovita } \\
+ \text { minerais opacos }\end{array}$ & $\begin{array}{l}\text { núcleo: anfibólio + feldspato + quarzto + } \\
\text { granada+ epidoto + minerais opacos } \\
\text { flancos: anfibólio + feldspato + quarzto + } \\
\text { epidoto + minerais opacos }\end{array}$ \\
\hline $\begin{array}{l}\text { Xistos } \\
\text { Sertânia }\end{array}$ & & $\begin{array}{l}\text { plagioclásio + quartzo + biotita } \pm \\
\text { muscovita } \pm \text { granada } \pm \text { sillimanita } \\
+ \text { minerais opacos } \pm \text { turmalina }\end{array}$ & & \\
\hline
\end{tabular}

TABELA 6 -

Paragêneses descritas na área estudada. 


\begin{tabular}{|c|c|c|c|c|c|c|c|c|c|c|c|c|c|c|c|c|c|c|c|c|c|}
\hline Amost & omini & 02 & THO2 & 203 & eOt & 10 & 90 & 0 & 20 & $\mathrm{~K} 20$ & $\overline{0 x}$ & Siv & AlIV & $=$ & n & $\mathrm{FeVI}$ & VI & MgVi & Ca & $\mathrm{Na}$ & $n$ \\
\hline Pl.16.3 & $-S P$ & 6,43 & 0,16 & 21,58 & 20,71 & 0,00 & 18,10 & 0,00 & 0,00 & 0,01 & & 729 & & & 0,012 & 1,789 & 0,000 & 2,786 & 0,000 & 0,000 &, 001 \\
\hline & 00 & 75 & 0,06 & 96 & 22,38 & 0,07 & 17,28 & 0,00 & 1 & 0,02 & 8,52 & 2734 & 354 & 293 & 0,005 & 1,913 & 0,006 & 2,632 & 000 & & \\
\hline TT62 & & & 0,08 & & 000 & 0,22 & 12,25 & 0,07 & 0,16 & 0,25 & 86,68 & 3,225 & & 30 & & & & & & 32 & 032 \\
\hline & CC- & 45 & & & & & 32 & & & 0 & 87,33 & 3,212 & & & & 831 & & 2,028 & & & 077 \\
\hline & & & $0, \mathrm{C}$ & & 2496 & & & & & 0,64 & 03 & 3,271 & & & & & & & & & 086 \\
\hline & & & 0 & & & & & & & & 1,2 & 3,097 & & & 00 & 964 & 022 & 2,049 & 12 & & 053 \\
\hline 51.6 & & & & & 1,8 & & 7 & 0,30 & & 55 &, 48 & 104 & & 888 & 0,006 & 973 & 025 & 2,043 & 33 & 006 & 0 \\
\hline & & & 0, & & & & 12 & 0,04 & 0 & 0,12 & 72 & 2,697 & & 30 & 0,007 & 356 & 093 & 1,088 & 105 & 0 & 017 \\
\hline & & & & & & & 19 & & & 0, & 40 & 2,693 & & & 04 & & & & & & 000 \\
\hline & & & & & & & & & & 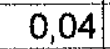 &, 82 & .719 & & & & 79 & 68 & 06 & & 04 & 006 \\
\hline & & & & & & & $a t$ & & & 0, & 88,85 & 2,672 & & 435 & of & 11 & 070 & 88 & & & 007 \\
\hline ST.3 & & 24,47 & 0,00 & 0,93 & 32,75 & 0,67 & 8,08 & 0,06 & 0,08 & 0,00 & 87,10 & 2,716 & & & 0,000 & 3,040 & 063 & 1,337 & 007 & 017 & 0,008 \\
\hline & & & & & & & & & & 0,02 & 87,33 & 2,805 & & 18 & 3,011 & 2,229 & 0,042 & 2,463 &, 007 & 0,023 & 0,003 \\
\hline & & & & & & & & 0, & & 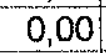 & 86,81 & 2,762 & & & & , & 0,046 & 2,449 & & 10 & 000 \\
\hline ST. 3 & & 25,77 & 0,00 &, 99 & 25,80 & $0,47[$ & 15,73 & 0,05 & 17 & 0,06 & 87,98 & 2,723 & & & 000 & 2,280 & 0,042 & 2,477 & 006 & 0,023 & 0,008 \\
\hline & & & & & & & & & & & 8206 & 3,029 & & 57 & 0,01 & 2,237 & 0,028 & 1,920 & 94. & 10 & 0,096 \\
\hline & & & & & 24 & 0, & 11,70 & 0, & & & 87,89 & 3,155 & & & & 2,098 & & & & &, 235 \\
\hline & & & & & & & 89 & & & & & & & & & 2,2 & & 555 & & 39 & 0,121 \\
\hline & & & & & & & 12,46 & & & & & 2,766 & & 1,19 & & 2,532 & , &, 979 & & 002 &, 014 \\
\hline T.338.B & CRG-MP & 28,11 & 0,06 & 19,90 & 27,15 & 0,55 & $\mid 0,0]$ & &, 10 & & &, 000 & 1,496 & 0 & 0,00 & 2,42 & 2,050 & 64 &, 055 & 0,021 & 0,05 \\
\hline
\end{tabular}

TABELA 7 -

Dados da química mineral das cloritas estudadas, calculadas com base em 14-oxigênios, com todo $\mathrm{Fe}=\mathrm{Fe}^{2+}$

NOTAÇÓES COMUNS A TODAS AS TABELAS: $c$ - borda do grazo; $c / b$ - entre de substituiçăo; $p$ - pós-xistosidade princpal

\begin{tabular}{|c|c|c|c|c|c|c|c|c|c|c|c|c|c|c|c|c|c|c|c|}
\hline Amostra & Dominio & $\overline{\mathrm{SiO} 2}$ & TiO2 & Al2O3 & $\mathrm{FeO}$ & MnO & $\mathrm{MgO}$ & $\mathrm{Na2O}$ & $\mathrm{K} 2 \mathrm{O}$ & TOX & SilV & AlIV & AIVI & TiVI & $\mathrm{FeVI}$ & $\mathrm{Mn} \mathrm{VI}$ & $\mathrm{Mg} \mathrm{VI}$ & NA & $\mathrm{K}$ \\
\hline $51-4$ & CC-SP & 47,05 & 0,01 & 37,02 & 0,92 & 0,01 & 0,61 & 0,87 & 9,64 & 96,13 & 3,097 & 0,903 & 1,950 & 0,000 & 0,050 & 0,001 & 0,059 & 0,111 & 0,810 \\
\hline $1-4$ & CC-SP & 45,97 & 0,09 & 36,95 & 1,02 & 0,01 & 0,57 & 0,87 & 9,79 & 95,27 & 3,042 & 0,958 & 1,925 & 0,004 & 0,056 & 0,001 & 0,056 & 0,112 & 0,827 \\
\hline ST. 26 & CC-SG & 50,01 & 0,22 & 32,89 & 2,68 & 0,00 & 2,01 & 0,34 & 8,89 & 97,04 & 3,241 & 0,759 & 1,753 & 0,011 & 0,145 & 0,000 & 0,194 & 0,043 & 0,735 \\
\hline ST.26 & CC-SG & 7,69 & 0,40 & 33,89 & 2,22 & 0,02 & 1,59 & 0,40 & 9,39 & 95,60 & 3,150 & 0,850 & 1,789 & 0,020 & 0,123 & 0,001 & 0,157 & 0,051 & 791 \\
\hline ST.27.1 & CC-SG & 49,29 & 1,10 & 35,53 & 1,76 & 0,00 & 1,07 & 0,76 & 4,46 & 93,97 & 3,195 & 0,805 & 1,910 & 0,054 & 0,095 & 0,000 & 0,103 & 0,096 & 0,369 \\
\hline ST. 27.1 & CC-SG & 9,53 & 0,97 & 36,51 & 1,72 & 0,05 & 0,89 & 0,74 & 3,63 & 94,04 & 3,188 & 0,812 & 1,958 & 0,047 & 0,093 & 0,003 & 0,085 & 0,092 & 0,298 \\
\hline ST.27.1 & CC-SG & 47,55 & 0,08 & 36,44 & 1,72 & 0,06 & 0,89 & 0,70 & 6,94 & 94,38 & 3,121 & 0,879 & 1,941 & 0,004 & 0,094 & 003 & 087 & 0,089 & 0,581 \\
\hline ST.27.1 & CC-SG & 47,37 & 0,81 & 36,25 & 1,57 & 0,06 & 1,10 & 0,93 & 8,80 & 96,89 & 3,073 & 0,927 & 1,845 & 0,040 & 0,085 & 0,003 & 0,106 & 0,117 & 0,728 \\
\hline ST.27.1 & CC-SG & 47,08 & 0,04 & 36,08 & 1,68 & 0,00 & 1,03 & 0,85 & 8,38 & 95,14 & 3,099 & 0,901 & 1,898 & 0,002 & 0,092 & 0,000 & 0,101 & 0,108 & 0,704 \\
\hline ST.62 & CC-SG & 43,04 & 0,00 & 30,10 & 7,80 & 0,05 & 3,64 & 0,21 & 4,94 & 89,78 & 3,061 & 0,939 & 1,585 & 0,000 & 0,464 & 0,003 & 0,386 & 029 & 0,448 \\
\hline ST. 200.2 & CRG-MP & 46,90 & 0,24 & 32,58 & 3,09 & 0,02 & 1,35 & 0,27 & 10,42 & 94,87 & 3,159 & 0,841 & 1,747 & 0,012 & 0,174 & 0,001 & 0,136 & 0,035 & 0,895 \\
\hline ST.203 & CRC & 53,32 & 0,6 & 32,46 & 5,09 & 0,04 & 1,75 & 0,25 & 3,81 & 97,33 & 3,361 & 0,639 & 1,772 & 0,029 & 0,268 & 002 & 164 & 0,031 & 0,306 \\
\hline ST.20 & CR & & 0,4 & 31,44 & 4,60 & 0,07 & 1,80 & 31 & 9,27 & 96,97 & 3,229 & 0,771 & 1,668 & 0,020 & 0,253 &, 004 & 177 & 540 & 0,778 \\
\hline ST.20 & CRC & 48,27 & 0, & 31,96 & 4,58 & 0,00 & 1,59 & 0,29 & 9,32 & 96,47 & 3,195 & 0,805 & 1,689 & 0,023 & 0,254 & 0,000 & 157 & 337 & 0,787 \\
\hline ST.203.1 & CRC & 46,92 & 0,64 & 32,45 & 4,56 & 0,00 & 1,27 & 0,39 & 9,20 & 95,43 & 3,144 & 0,856 & 1,708 & 0,032 & 0,256 &, 000 &, 127 & 51 & 0,787 \\
\hline ST. 20 & & 47,93 & 0,2 & 32,09 & 3,95 & 0,00 & 1,50 & 0,28 & 9,23 & 95,44 & 3,195 & 0,805 & 1,718 & 0,023 & 0,220 & 0,000 & 0,149 & 36 & 0,785 \\
\hline ST.203.1 & CRG-MP & 49,15 & 0,27 & 31,48 & 4,79 & 0,00 & 1,75 & 0,24 & 9,30 & 96,98 & 3,234 & 0,766 & 1,677 & 0,013 & 264 & 0,000 & 0,172 & 0,031 & 0,781 \\
\hline ST.205.2 & CRG-MP & 48,69 & 0,38 & 10 & 2,24 & 0,06 & 1,94 & 0,20 & 10,78 & 97,72 & 3,170 & 0,830 & 1,736 & 0,019 &, 122 & 0,003 & 0,188 & 0,025 & 0,895 \\
\hline ST.205 & CRG & 46,56 & 0 & 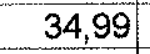 & 1,62 & 0,06 & 1,27 & 0,51 & 10,03 & 95,74 & 3,081 & 0,919 & 1,810 & 0,035 & 0,090 & 0,003 & 0,125 & 065 & 0,847 \\
\hline ST.205.2 & CRG-MP & 47,09 & 0,81 & 34,79 & 1,70 & 0,08 & 1,36 & 0,56 & 9,88 & 96,27 & 3,096 & 0,904 & 1,794 & 0,040 & 0,093 & 0,004 & 33 & 0,071 & 0,829 \\
\hline ST.205.2 & CRG & 31 & 0 & 33,40 & 1,95 & 0,06 & 1,42 & 0,50 & 9,79 & 94,21 & 3,135 & 0,865 & 1,784 & 0,024 & 0,110 & 0,003 & 0,142 & 0,065 & 0,840 \\
\hline ST.314 & CRG & 4 & 0 & 34,54 & 1,39 & 0,00 & 1,18 & 0,52 & 10,00 & 95,58 & 3,115 & 0,885 & 1,808 & 0,041 & 0,077 & 0,000 & 0,116 & 0,067 & 0,844 \\
\hline ST.314 & CRG-MP & 46,29 & 0,91 & 35,09 & 1,46 & 0,00 & 1,10 & 0,54 & 9,86 & 95,25 & 3,073 & 0,927 & 1,820 & 0,045 & 081 & 000 & 0,109 & 0,070 & 0,835 \\
\hline ST.337i & & 47,64 & 0,34 & & 2,81 & 0,00 & 135 & 0,19 & 9,37 & 94,44 & 3,191 & 0,809 & 1,777 & 0,017 & 0,157 & 0,000 & 0,135 & 0,025 & 0,801 \\
\hline ST.337 & & 48,39 & 0, & 32,30 & 2,80 & 0,05 & 1,75 & 0,11 & 9,71 & 95,47 & 3,212 & 0,788 & 1,739 & 0,018 & 0,155 & 0,003 & 0,173 & 014 & 0,822 \\
\hline ST. $337 \mathrm{i}$ & CRG-MP & 49,43 & 0,36 & 31,90 & 3,58 & 0,00 & 1,90 & 0,20 & 8,99 & 96,36 & 3,245 & 0,755 & 1,714 & 0,018 & 0,197 & 0,000 & 0,186 & 0,025 & 0,753 \\
\hline ST-541 & & $-7,12$ & & & 1,45 & 0,00 & 1,09 & 0,58 & 9,90 & $94,61$. & 3,145 & 0,855 & 1,820 & 0,024 & 0,081 & 0,000 & 0,108 & 0,075 & 0,843 \\
\hline ST-541 & & 47,95 & 0,50 & 33,90 & 1,78 & 0,00 & 1,41 & 0,75 & 9,91 & 96,20 & 3,154 & 0,846 & 1,783 & 0,025 & 0,098 & 0,000 & 0,138 & 096 & 0,832 \\
\hline ST-541 & CRG-Spse & 47,89 & 0,48 & 33,64 & 1,94 & 0,00 & 1,66 & 0,73 & 9,86 & 96,20 & 3,153 & 0,847 & 1,764 & 0,024 & 0,107 & 0,000 & 0,163 & 0,093 & 0,828 \\
\hline
\end{tabular}

TABELA 11 -

Análise química das micas brancas em metassedimentos dc complexos Riacho Gravatá e Cachoeirinha e Xistos Sertânia
calculados com base em 11-oxigênios, com todo $F e=\mathrm{Fe}^{2+}$ 


\begin{tabular}{|c|c|c|c|c|c|c|c|c|c|c|c|c|c|c|c|c|c|c|c|}
\hline Amostra & Domínio & $\mathrm{S1O2}$ & $\mathrm{TiO}_{2}$ & $\mathrm{Al} 2 \mathrm{O}_{3}$ & $\mathrm{FeO}$ & Mno & $\mathrm{MgO}$ & $\mathrm{Na2O}$ & $\mathrm{K} 2 \mathrm{O}$ & TOX & SIIV & AIIV & AIVI & TIVI & $\mathrm{FeVI}$ & $\mathrm{MnVI}$ & $\mathrm{Mg} \mathrm{VI}$ & $\mathrm{Na}$ & 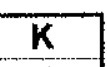 \\
\hline Pl-4. & CC-SP & 34,66 & 2,14 & 18,91 & 19,95 & 0,05 & 9,56 & 0,16 & 8,10 & 93,53 & 2,680 & 1,320 & 0,403 & 0,124 & 1,290 & 0,003 & 1,102 & 0,024 & 0,799 \\
\hline Pl.16.3 & CC-SP & 36,65 & 2,68 & 19,30 & 17,32 & 0,00 & 11,06 & 0,23 & 6,85 & 94,09 & 2,742 & 1,258 & 0,444 & 0,151 & 1,084 & 0,000 & 1,233 & 0,033 & 0,654 \\
\hline Pl.16.3 & CC-SP & 36,86 & 2,85 & 18,87 & 17,74 & 0,13 & 11,17 & 0,23 & 7,27 & 95,12 & 2,743 & 1,257 & 0,398 & 0,159 & 1,104 & 0,008 & 1,239 & 0,033 & 0,690 \\
\hline Pl.16.3 & CC-SP & 37,52 & 2,55 & 19,60 & 17,41 & 0,08 & 10,71 & 0,12 & 6,85 & 94,84 & 2,777 & 1,223 & 0,488 & 0,142 & 1,078 & 0,005 & 1,181 & 0,017 & 0,647 \\
\hline Pl.16.3 & CC-SP & 36,62 & 2,48 & 19,48 & 17,44 & 0,11 & 10,47 & 0,14 & 7,43 & 94,17 & 2,748 & 1,252 & 0,472 & 0,140 & 1,095 & 0,007 & 1,171 & 0,020 & 0,711 \\
\hline PI.16.3 & CC-SP & 37,00 & 1,96 & 19,45 & 17,80 & 0,08 & 10,84 & 0,13 & 6,94 & 94,20 & 2,769 & 1,231 & 0,484 & 0,110 & 1,114 & 0,005 & 1,209 & 0,019 & 0,663 \\
\hline PI.16.3 & CC-SP & 36,82 & 2,57 & 19,82 & 17,74 & 0,00 & 10,98 & 0,19 & 7,34 & 95,46 & 2,725 & 1,275 & 0,455 & 0,143 & 1,098 & 0,000 & 1,211 & 0,027 & 0,693 \\
\hline PI.16.3i & CC-SP & 39,01 & 1,88 & 20,72 & 13,86 & 0,04 & 13,34 & 0,23 & 6,20 & 95,28 & 2,801 & 1,199 & 0,556 & 0,102 & 0,832 & 0,002 & 1,428 & 0,032 & 0,568 \\
\hline Pl.16.3i & CC-SP & 39,75 & 1,83 & 20,85 & 13,74 & 0,00 & 13,54 & 0,23 & 5,74 & 95,68 & 2,827 & 1,173 & 0,575 & 0,098 & 0,817 & 0,000 & 1,435 & 0,032 & 0,521 \\
\hline PI.16.3i & CC-SP & 38,52 & 1,69 & 20,89 & 13,64 & 0,07 & 13,83 & 0,25 & 6,71 & 95,60 & 2,767 & 1,233 & 0,536 & 0,091 & 0,819 & 0,004 & 481 & 335 & 0,615 \\
\hline $\mathrm{Pl}-23$ & CC-SG & 36,36 & 1,69 & 18,95 & 16,56 & 0,10 & 12,65 & 0,09 & 8,79 & 95,19 & 2,716 & 1,284 & 0,385 & 0,095 & 1,035 & 0,006 & 1,408 & 0,013 & 0,838 \\
\hline $\mathrm{Pl}-23$ & CC-SG & 36,53 & 1,60 & 19,16 & 16,41 & 0,09 & 12,82 & 0,14 & 9,23 & 95,98 & 2,710 & 1,290 & 0,386 & 0,089 & 1,018 & 0,006 & 417 . & 020 & 0,874 \\
\hline PI-23 & CC-SG & 36,47 & 1,62 & 19,41 & 16,67 & 0.01 & 12,90 & 0,13 & 9,22 & 96,43 & 2,695 & 1,305 & 0,385 & 0,090 & 1,030 & 0,001 & 1,420 & 0,019 & 0,869 \\
\hline $\mathrm{PI}-23$ & CC-SG & 36,50 & 1,69 & 19,50 & 16,20 & 0,06 & 12,03 & 0,07 & 9,05 & 95,10 & 2,724 & 1,276 & 0,440 & 0,095 & 1,011 & 0,004 & 338 & 010 & 0,862 \\
\hline PI-23* & CC-SG & 36,29 & 2,08 & 19,63 & 16,10 & 011 & 12,26 & 0,13 & 9,23 & 95,83 & 2,692 & 1,308 & 0,409 & 0,116 & 0,999 & 0,007 & 356 & 019 & 0,874 \\
\hline $\mathrm{Pl}-23^{\star}$ & CC-SG & 36,30 & 1,69 & 19,43 & 16,37 & 0,09 & 12,67 & 0,08 & 9,22 & 95,85 & 2,696 & 1,304 & 0,397 & 0,094 & 1,017 & 006 & 402 & 12 & 874 \\
\hline $\mathrm{Pl}-23^{*}$ & CC-SG & 36,54 & 1,40 & 19,71 & 16,76 & 0,02 & 12,55 & 0,14 & 9,08 & 96,20 & 2,703 & 1,297 & 0,422 & 0,078 & 1,037 & 001 & 384 & 020 & 0,857 \\
\hline $\mathrm{Pl}-23^{*}$ & CC-SG & 36,79 & 1,85 & 19,67 & 16,15 & 0,05 & 12,21 & 0,14 & 9,03 & 95,89 & 2,720 & 1,280 & 0,434 & 0,103 & 0,999 & 0,003 & 1,345 & 0,020 & 0,852 \\
\hline ST. 26 & CC-SG & 35,70 & 1,73 & 16,31 & 24,68 & 0,20 & 8,47 & 0,00 & 6,45 & 93,54 & 2,797 & 1,203 & 0,304 & 0,102 & 1,617 & 0,013 & 0,989 & 0,000 & 0,645 \\
\hline ST. 26 & CC-SG & 37,37 & 1,54 & 17,12 & 20,57 & 0,14 & 9,29 & 0.11 & 7,21 & 93,35 & 2,871 & 1,129 & 0,421 & 0,089 & 321 & 009 & 063 & 016 & 0,707 \\
\hline ST. $26^{\star}$ & CC-SG & 36,91 & 1,92 & 17,41 & 20,70 & 0,1 & 9,18 & 0,06 & 7,52 & 93,85 & 2,830 & 1,170 & 0,404 & 0,111 & .327 & 010 & 049 & 09 & 736 \\
\hline ST. $26^{*}$ & CC-SG & 36,50 & 1,84 & 17,61 & 20,32 & 0,1 & 8,90 & 0,10 & 8,14 & 93,56 & 2,816 & 1,184 & 0,418 & 0,107 & 311 & 010 & 023 & 015 & 0,801 \\
\hline ST.E. & CRG-MP & 35,29 & 2,43 & 16,65 & 24,49 & 0,07 & 5,47 & 0,13 & 8,68 & 93,21 & 2,812 & 1,188 & 0,377 & 0,146 & 32! & 005 & 650 & 020 & 0,882 \\
\hline ST.E & CRG-MP & 34,74 & 2,70 & 16,85 & 24,66 & 0. & 5,55 & & 9,03 & 93,77 & 2,765 & 1,235 & 0,346 & 162 & & 014 & 658 & & 0,917 \\
\hline ST.E & CRG-MP & 34,65 & 2,42 & 17,05 & 24,92 & 0,2 & 5,42 & 0,11 & 8,94 & 93,72 & 2,762 & 1,238 & 0,364 & 0,145 & 661 & 014 & 644 & 017 & 0,909 \\
\hline ST.E. 200 & CRG-MP & 34,48 & 2,18 & 17,00 & 25,42 & 0,1 & 6,55 & 0,03 & 7,88 & 93,71 & 2,738 & 1,262 & 0,330 & 0,130 & 1,688 & 0,011 & 775 & t & 0,798 \\
\hline ST.203.1 & CRG-MP & 34,97 & 82 & 1699 & 2641 & & 669 & & 9,87 & 3,98 & 724 & 1,276 & 0,277 & 07 & 720 & 011 & 777 & 8 &, 981 \\
\hline ST. 2 & CRG-MP & 34,42 & 1,94 & 16,39 & 26,02 & & $6,41]$ & $10]$ & 10,14 & 5,73 & 2,726 & 1,274 & 0,257 & 116 & 1,724 & 0,021 & 757 & 015 &, 025 \\
\hline & CRG-MP & 34,66 & & 1665 & 26,66 & & & & 988 & 53 & 2,720 & & 0,261 & & & 09 & 725 & 024 & 0,989 \\
\hline ST.2 & CRG-MP & 35,24 & - & 16,73 & 25,26 & 0, & $59 \mid$ & & 323 & 5,55 & 2,760 & 1,240 & 0,305 & 19 & 655 & 0,014 & 781 & 026 &, 922 \\
\hline ST.2 & CRG-MP & & & & & & & & & & & & & & & & 52 & & 888 \\
\hline ST.2C & CRG-MF & 35,22 & 2,01 & 1 & 25,9 & & 6,76 & & 56 & 96,61 & 2,741 & 1,259 & 0,284 & 118 & 1,686 & 0,020 & 784 & 008 & 0,949 \\
\hline ST.2 & CRG & & & & & & & & & & & & & & & 013 & 93 & & 0,987 \\
\hline ST.2L & CRG & 34,87 & 2,20 & 7 & 24 & & 66 & & 9,43 & 94,43 & 2,769 & 1,231 & 0,280 & 131 & 1,653 & 0,013 & 781 &, 015 & 0,955 \\
\hline ST. 2 & CRG & & 2,24 & & & & & & & & & & & & & & 771 & & 0,960 \\
\hline ST.20 & CRG-MP & 35,6 & 2,2 & 16,49 & 24,53 & 0,10 & 6,56 & 0,00 & 9,41 & 94,93 & 2,797 & 1,203 & 0,323 & 0,130 & 1,610 & 0,007 & 0,767 & 000 & 0,942 \\
\hline ST.205.2 & CRG-MP & 37,16 & 1,04 & 18,22 & 18,14 & 0,28 & 10,60 & & 9,22 & 77 & 2,813 & 1,187 & 39 & 59 & 49 & 18 & 196 & & 891 \\
\hline & CRG & & & & & & & & 922 & 1. & 2813 & 37. & 11 & 58 & & 17 & 237 & 13. &, 893 \\
\hline ST.2 & CRG & 37,0 & 1 & 17,87 & 17,7 & & 10.85 & & 9,12 & 94,44 & 2,812 & 1,188 & 411 & 0,076 & 27 & 22 & 227 & & 883 \\
\hline & CRG & & & & 18 & & 6 & & & 24 & 2,773 & 1,227 & 67 & 0,085 & & & 239 & 06 & 0,891 \\
\hline ST. 2 & CRG-MP & 36,74 & 1. & 17,50 & 18 & 0,2 & 10,97 & & 3,59 & 95,78 & 2,775 & 225 & 334 & 0,100 & 97 & & 1,235 & 50 & 0,924 \\
\hline & & & & & & & & & & & 2,784 & & & & & & 1,256 & 15 & 2859 \\
\hline ST.205.2 & CRG-MP & 37,30 & 1.4 & 17,5 & 18,02 & 0 , & 11,06 & 0,1 & 9,28 & 95,04 & 2,817 & 1,183 & 0,380 & 0,084 & 1,138 & 0,016 & 1,245 & 0,016 & 0,894 \\
\hline ST.3 & CRC & 35 & 0 , & & & & & & 53 & & & & & & & & & & 73 \\
\hline ST: & & & & & 10 & & & & 05 & & 2,792 & 1,208 & 382 & 083 & 1,244 & 015 & 156 & 0,007 &, 890 \\
\hline ST. $314^{*}$ & CRG-MP & 36,41 & 1,42 & 17,12 & 18,91 & 0,3 & 10,20 & 0, & 9,42 & 93,93 & 2,808 & 1,192 & 0,364 & 0,082 & 1,220 & & 172 & & 927 \\
\hline ST-4 & & & & & & & & & & & 2666 & 1,334 & $\Delta 45$ & & 1,076 & 008 & 1,192 & 0,020 & 0,923 \\
\hline ST-4 & Ser & 35 & & & 18 & & 5 & & 46 & 48. & 2,669 & 31 & 442 & 125 & 1,144 & 008 & 141 & 0,009 & 0,910 \\
\hline ST-4 & & & & & & & & & & & & & & & & & 151 & & \\
\hline ST-488 & Ser & 35 & & 20,13 & 17, & & 10,2 & & 9,27 & 22 & 2,659 & 1,341 & 0,448 & 22 & 1,115 & 207 & 179 & 016 & 0,892 \\
\hline ST-488* & & & & & & & & & & & & & & & & & 176 &, 013 & 001 \\
\hline ST $-488 \mathrm{i}$ & Sertânia & 33,95 & 1,21 & 19,43 & 20,02 & 0,13 & 11,26 & 0,08 & 8,47 & 94,55 & 2,608 & 1,392 & 0,368 & 0,070 & 1,286 & 0,008 & 1,289 & 0,012 & 0,830 \\
\hline ST.2 & CRG & 37,8 & 1,2 & 17, & 17. & & & & 7,02 & & & 1,155 & 427 & & & & 1,337 & 06 & 0,671 \\
\hline ST.2 & $C R$ & & & & 17 & & & & & & & & & 0,080 & 1,122 & 010 & 307 & 0,009 & 0,683 \\
\hline ST.206.2 & CRG-N & 38,53 & 1, & 17. & 18, & 0, & & & & & 2,8 & 00 & & & & & 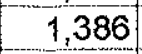 & 77 & 0,624 \\
\hline & & & & & & & & & & & & & & & & 0,015 & 1,363 & 0,013 & 0,616 \\
\hline & CRG-MP & 38,44 & 1,15 & 18,17 & 18,61 & 0,22 & 12,38 & 0,14 & os & 95,96 & 2,825 & 1,17 & 0,406 & 0,064 & & 0,014 & 1,358 & 0,020 & 0,643 \\
\hline & & & & & 1000 & 015 & & & 07 & 5,61 & 2,835 & 1,165 & 0,418 & 0,065 & 1,125 & 0,009 & 1,356 & 0,003 & 0,665 \\
\hline
\end{tabular}

TABELA 8 -

Análise química de biotitas realizadas no presente trabalho, calculadas com base em 11-oxigênios, com todo $\mathrm{Fe}=\mathrm{Fe}^{2+}$ 


\begin{tabular}{|c|c|c|c|c|c|c|c|c|c|c|c|c|c|c|c|c|c|c|}
\hline Amostra & Domínio & $\overline{02}$ & 203 & $\mathrm{FeO}$ & $\mathrm{CaO}$ & 20 & $\mathrm{~K} 2 \mathrm{O}$ & TOTAL & SI & AI & $\mathrm{Fe}$ & $\mathrm{Ca}$ & $\mathrm{Na}$ & $\mathbf{K}$ & T Cat & $\overline{X C A}$ & XNA & $\overline{\mathbf{X K}}$ \\
\hline Pl-4 & CC-SP & 62,40 & 24,03 & 0,00 & 5,51 & 7,94 & 0,11 & 99,99 & 2,759 & 1,252 & 0,000 & 0,261 & 0,681 & 0,006 & 4,959 & 0,275 & 0,718 & 0,007 \\
\hline Pl-4b & CC-SP & 59,01 & 27,19 & 0,13 & 8,75 & 5,72 & 0,16 & 100,96 & 2,605 & 1,415 & 0,005 & 0,414 & 0,490 & 0,009 & 4,937 & 0,454 & 0,537 & 0,010 \\
\hline$P 1-4 \mathrm{c} / \mathrm{b}$ & CC-SP & 58,04 & 27,35 & 0,09 &, 73 & 5,77 & 0,15 & 100,13 & 2,586 & 1,437 & & 0,417 & & 0,009 & 4,949 & 0,451 & 0,540 & 0,009 \\
\hline $\mathrm{Pl}-4 \mathrm{c} / \mathrm{b}$ & CC-SP & 61,59 & 25,18 & 0,07 & 6,23 & 7,19 & 0,21 & 100,47 & 2,714 & 1,308 & 0,003 & 0,294 & 0,614 & 0,012 & 4,945 & 0,320 & 0,668 & 0,013 \\
\hline $\mathrm{Pl}-4 \mathrm{~b}$ & CC-SP & 59,55 & 25,97 & 0,09 & 7,94 & 6,73 & 0,07 & 100,35 & 2,644 & 1,359 & 0,003 & 0,378 & & 004 & 4,968 & 0,393 & 0,603 & 0,004 \\
\hline $\mathrm{PI} .16 .3 \mathrm{~b}$ & CC-SP & 294 & 23,47 & 0,06 & 4,94 & 7,69 & 0,06 & 99,16 & 2,794 & 1,228 & 0,002 & 0,235 & 0,662 & 0,003 & 4,925 & 0,261 & 0,735 & 0,004 \\
\hline Pl.16.3b & CC-SP & 62,04 & & 0,10 & 4,92 & 8,42 & 0,08 & 98,57 & 2,783 & 1,217 & 0,004 & 0,236 & 0,732 & 0,005 & 977 & 0,243 & 0,752 & 0,005 \\
\hline Pl.16. & CC-SP & 4,23 & 23,43 & 0,03 & 4,47 & 8,51 & 0,11 & 100,78 & 2,807 & 207 & 001 & 0,209 & 0,721 & 0,006 & 953 & 0,223 & 0,770 & 0,007 \\
\hline PI.16.3c' & CC-SP & 3,86 & 24,11 & 0,02 & 4,80 & 8,18 & 0,12 & 101,09 & 2,784 & 1,239 & 0,001 & 0,224 & 0,691 & 0,007 & 946 & 0,243 & 0,750 & 0,007 \\
\hline Pl.16.3 & CC-SP & 65,38 & 23,63 & 0,03 & 3,92 & 8,25 & 0,06 & 101,27 & 2,830 & 206 & 001 & 0,182 & 0,692 & 0,003 & 915 & 0,207 & 0,789 & 0,004 \\
\hline $\mathrm{Pl}-23$ & CC-SG & 4.38 & 22, & 011 & 3,08 & 9,34 & 0,06 & 99,28 & 2,850 & 164 & 004 &, 146 & 0,802 & 0,003 & 970 & 0,154 & 0,843 & 0,004 \\
\hline $\mathrm{Pl}-23 \mathrm{~b}$ & CC-SG & 6 & 22 & 0, & & 9,37 & 0.08 & 04 & 2,854 & 1,151 & 0,006 & 159 & 0,799 & 0,004 & 973 & 0,165 & 0.830 & 0,005 \\
\hline $\mathrm{Pl}-23 \mathrm{~b}$ & CC-SG & 64 & & 0,10 & & 9,13 & 0,1 & 0,18 & 2,843 & 1,168 & 0,004 & 166 & 777 & 0,006 & 964 & 0,175 & 0,819 & 0,006 \\
\hline $\mathrm{PI}-23 \mathrm{C}$ & CC-SG & 64,36 & $22, \epsilon$ & 0,04 & 3,5 & 9,14 & 0,05 & 79 & 2,837 & 1,178 & 0,001 & 0,167 & 0,781 & 0,003 & 966 & 0,175 & 0,822 & 0,003 \\
\hline ST.2 & CRG-MP & 63,00 & 23 & & 4,9 & 8,49 & 0,07 &, 73 & 2,790 & 1,212 & 0,000 & 235 & 0,729 & 0,004 & 970 & 0,243 & 0,753 & 0,004 \\
\hline ST.2 & CRG-MF & & 21 , & 0,06 & 2,51 & 9,49 & 0,0 & 98,50 & 2,880 & 1,138 & 0,002 & 120 & 819 & 0,002 & 961 & 0,127 & 0,870 & 0,002 \\
\hline ST.2 & CRG-MP & & & 0,11 & & 8,89 & 0,0 & 26 & 2,833 & 1,179 & 0,004 & 81 & 0,757 & 0,004 & 958 & 0,192 & 0,803 & 0,005 \\
\hline ST.2 & CRG-MP & 38 & 23, & 0,07 & 4,7 & 8,53 & 0,06 & 100,22 & 2,799 & 1,208 & 0,003 & 0,222 & 0,728 & 0,003 & 963 & 0,233 & 0,764 & 0,004 \\
\hline ST $200.2 \mathrm{C}$ & CRG-MP & 63,43 & 23,58 & & 5,27 & 8,37 & 0,09 & 74 & 2,782 & 1,219 & 0,000 & 248 & 0,712 & 0,005 & 966 & 0,257 & 0,738 & 0,005 \\
\hline ST. 20 & CRG-MP & 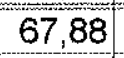 & 20,48 & 0,15 & 0,84 & 0,15 & 00 & 55 & 2,969 & 1,056 & 0,005 & 0,039 & 0,861 & 0,003 & 4,934 & 0,044 & 0,953 & 0,003 \\
\hline ST.2 & CRC & 61 & 20 & 0 & 0,46 & 10,60 & 0,0 & 98 & 2,986 & 1,036 & 0,003 & 021 & 0,895 & 0,002 & 944 & 0,023 & 0,975 & 0,002 \\
\hline ST.203.1c & CRG-MP & 70,07 & 20,66 & 0,10 & 0,32 & 9,35 & 0,04 & 54 & 3,011 & 1,047 & 0,004 & 0,015 & 0,779 & 0,002 & 857 & 0,019 & 0,979 & 0,003 \\
\hline & CRG-SPS & & 1 & 0 & 3 & 8,87 & 05 & 98 & 2,839 & 1,191 & 0,003 & 0,140 & 0,756 & 0,029 & 4,958 & 0,152 & 0,817 & 0,031 \\
\hline ST-541c & CRG-SPSE & 63,36 & 22,91 & 0,03 & 3,71 & 9,00 & 0,09 & 9,10 & 2,816 & 1,200 & 0,001 & 0,177 & 0,776 & 0,005 & 4,974 & 0,185 & 0,810 & 0,005 \\
\hline ST-488i' & Sertânia & 60,88 & 25,14 & 0,31 & 6,77 & 6,89 & 0,1 & 0,14 & 2,698 & 1,314 & & & 0,592 & 0,008 & 945 & 0,349 & 0,642 & 0,009 \\
\hline & & & & & & 7,71 & & 43 & 2,721 & 1,279 & 0,018 & 0,285 & 0,668 & 0,006 & 4,976 & 0,297 & 0,697 & 0,006 \\
\hline ST-488b & Sertânia & 63,57 & 23,63 & 0,15 & 4,7 & 8,03 & 0,0 & 0,22 & 2,795 & 1,225 & 0,006 & 224 & 684 & 0,005 & & 0,245 & 0,749 & 0,006 \\
\hline ST- $488 \mathrm{~b}$ & Sertânia & & & & & 7,59 & & 0,14 & 2,748 & 1,274 & 0,004 & 0,262 & 0,649 & 0,007 & 4,943 & 0,285 & 0,707 & 0,007 \\
\hline ST-488C & Sertânia & 62,14 & 24,69 & 0,09 & 5,55 & 7,27 & 0,2 & 99 & 2,744 & 1,285 & 0,003 & 0,263 & 0,622 & 0,014 & 932 & 0,292 & 0,692 & 0,016 \\
\hline ST $-488 \mathrm{C}$ & & & & 0,08 & 5,1 & 7,83 & 0 & & 2,789 & 1,225 & & 0,243 & 0,670 & 0,007 & 937 & 0,264 & 0,728 & 0,007 \\
\hline ST- 488 & Sertânia & 61,57 & 23,68 & 0,15 & 5,07 & 8,23 & 0,08 & 98,78 & 2,758 & 1,250 & 0,006 & 0,243 & 0,715 & 0,005 & 4,977 & 0,253 & 0,742 & 0,005 \\
\hline
\end{tabular}

TABELA 9 -

Dados da química mineral dos feldspatos das rochas metassedimentares calculados com base em 8-oxigênios, com todo $\mathrm{Fe}=\mathrm{Fe}^{2+}$ 


\begin{tabular}{|c|c|c|c|c|c|c|c|c|c|c|c|c|c|c|c|c|c|c|c|c|}
\hline Amostra & $\operatorname{mini}$ & 02 & $\mathrm{THO}_{2}$ & 1203 & $\mathrm{FeO}$ & Mno & MgO & $\mathrm{CaO}$ & TOX & Si & $\because$ & Al & $\mathrm{Fe}$ & $\mathrm{Mn}$ & $M$ & $\mathrm{Ca}$ & XFE & IN & DMG & $X \subset A$ \\
\hline $1-4$ & CC-SP & 25 & & 21,47 & 33,77 & 3,54 & 3,64 & 1,22 & 101,91 & 3,010 & 0,001 & 1,992 & 2,223 & 0,236 & 0,427 & 0,103 & 0,744 & 0.079 & 0,143 & \\
\hline-4 & $S P$ & 3,00 & & 21,72 & 33,63 & 4,06 & 3,62 & 1,21 & 102,24 & 2987 & 0,000 & 2,013 & 2211 & 0,070 & 0,424 & 0.102 & 0,735 & 0,090 & 0,141 & \\
\hline Pl-4 & $S P$ & 38 & & 36 & 25 & 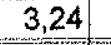 & 4,30 & 1,3 & 101,85 & & 0,001 & 1,976 & & 0,215 & 503 & 109 & 725. & 0,072 & 0,167 & \\
\hline PI.16. & C-SP & 3,17 & 1 & 20,75 & 33,37 & 9 & 3,55 & 0,83 & 99,97 & 3,054 & 07 & 1,8 & 2,233 & 0,216 & 0,423 & 071 & 0,759 & 073 & 144 & \\
\hline PI.16 & $-S P$ & 74 & & & & 196 & 5,07 & 0,87 & 97,94 & 3,042 & 0,000 & & 2,115 & 0,134 & 0,609 & 075 & 0,721 & 046 & 0,208 & \\
\hline PI.16.3c & CC-SP & 96 & 0 & 2 & 97 & 2,29 & 4,94 & 0,87 & 100,08 & 3,073 & 0,000 & 958 & 2,109 & 0,153 & 0,581 & 074 & 0,723 & 052 & 0,199 & \\
\hline $\mathrm{Pl}-23 \mathrm{~b} / \mathrm{b}$ & CC-SG & .45 & 0,00 & 21,42 & 32,77 & 4,72 & 3,78 & 1,34 & 101,48 & 2,971 & 0,000 & 2,003 & 2,174 & & 0,447 & 114 & 0,712 & 104 & 146 & \\
\hline $\mathrm{Pl}-2$ & 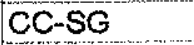 & 67 & 0,06 & & & 4,74 & 3,77 & 1,27 & 100,95 & 3,000 & 0,004 & 1,971 & & 000 & 0,447 & 108 & 0,712 & 0,105 & 147 & \\
\hline Pl-23b & CC-SG & 52 & 0,02 & tol & 32,32 & 66 & 3,83 & 1,64 & 0,89 & 2,992 & 001 & 1,965 & 2,156 & 0,315 & 0,455 & 140 & 0,703 & 103 & 0,148 & \\
\hline $\mathrm{Pl}-23 \mathrm{C}$ & CC-SG & 81 & 57 & & 30,86 & 4,86 & 3,37 & 1,32 & 100,19 & 3,008 & 0,004 & 2,054 & 2,054 & 0,328 & 0,400 & 113 & 0,710 & 113 & 138 & \\
\hline $\mathrm{Pl}-2$ & & & 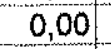 & & 32,44 & 51 & 3,72 & 1,41 & 101,47 & 020 & 0,000 & 1,989 & 2,152 & 0,339 & 0,440 & 120 & 0,706 & 111 & 0,144 & \\
\hline D10? & CC. & & 0,00 & & & & 83 & 1,37 & 24 & 3,003 & 000 & 1,969 & 2129 & 0,336 & & 118 & 0,700 & 111 & 0,150 & \\
\hline $\mathrm{Pl}-23 \mathrm{C}$ & CC-SG & 24 & 0,02 & 20,98 & 31,58 & 4,86 & 3,41 & 1,28 & 99,37 & 3,007 & 0,001 & 1,997 & 2,133 & & & 0,111 & 0,714 & 111 & 0,137 & \\
\hline ST. & & & 0,0 & & 2829 & & 0,99 & 8,32 & 14014 & 3,024 & 0,000 & 1,946 & 1,878 & 0,331 & 117 & & 0,619 & 2,109 & 030 & \\
\hline STSS & CC & 61 & 0,13 & & 25,88 & & 94 & 53 & & & 008 & 1,951 & 43 & 0.407 & & & 81. & 136 & 38 & \\
\hline$T 0$ & & 02 & 0,14 & & 27,02 & $5 !$ & 1,00 & 8,24 & 100,18 & 3,035 & 0,008 & 1,953 & 808 & 0,349 & & 707 & 606 & 117 & 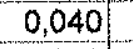 & \\
\hline ST.S & & & 0.1 & & & & 0,92 & 8,96 & 10 & 3,018 & 0,007 & 1,940 & 1,811 & 0,365 & 108 & 757 . & 0,596 & 0,120 & 0,036 & \\
\hline ST.A & $\mathrm{Cc}$ &, 90 & 0,0 & & 33, & & 2,51 & 1,7 & 100,71 & 3,037 & 0,00 & 1,953 & 2,269 & 0,269 & & & 0,759 &, 090 & 0,100 & \\
\hline & & & & & 31, & 4,0 & 2,54 & 1,82 & 98,59 & 3,077 & 0,000 & 1,960 & 2,159 & 0,281 & & & 743 & & & \\
\hline & & & & & & & & & & 3,045 & 0,000 & 1,968 & 2,218 & 0,264 & . & 74 & 0,750 & & 01 & \\
\hline ST.A & CC- & ,28 & 00 & & 00,00 & 4,53 & 2,69 & 0,80 & 3,01 & 3,033 & 0,000 & 1,987 & & 0,312 & & & 760 & 106 & 110 & 0,0 \\
\hline ST. & & & & & 23,35 & 7,79 & 0,97 & 8,94 & 99,66 & 3,045 & 0,000 & 1,953 & 1,5 & 0,529 & 6 & 88 & 526 & & 000 & \\
\hline ST. & c & & & & & & & & & & 007 & 1,923 & 1,5 & 0,601 & 4 & 38. & 502 & & & \\
\hline ST. & $\mathrm{CC}$ & & & & 22,19 & & & & 52 & & 009 & 1,776 & & & & & & & & \\
\hline & & & & & 23,97 & 7,07 & 4 & 9,05 & 99,73 & 3,041 & 0,013 & 1,934 & 1,608 & 0,480 & 24 & & 0,538 & & & \\
\hline ST. & & & & & & & 0,75 & & & & 0,020 & 1,9 & 2,157 & & 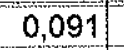 & 0,608 & 0,716 & 62. & 030 & 0,2 \\
\hline & & & & & & & & & 100,32 & & 0,01 & 1,929 & 2 & & & & & & & \\
\hline & & & & & & & 0,93 & & 98,92 & 79 & 007 & 1,931 & 2,174 & 0,045 & 12 & &, 742 & 15 & 03 & 0,2 \\
\hline ST. & & & & & & & 0,67 & & 101,61 & & & & & & & & 634 & 14 & 12 & \\
\hline & & & & & 27 & & & & & & & & & & & & & & & \\
\hline & & & & & & & 0,50 & & & & 0,0 & & & & & & 19 & & & \\
\hline & & & & & & & & & & & & & & & & & & & & \\
\hline & & & & & 28, & & 0,01 & 10 & 3]. & 3,022 & 0,00 & 1,938 & 1,925 & 0,370 & & & & & & \\
\hline & & & & & & & 2,30 & & & 3,023 & 0,0 & 10 & & & & & 648 & 53 & 00 & 0,2 \\
\hline & & & & & 28 & & 166 & & & & & & & & & & & & & \\
\hline & & & & & 26 & & & & & & 0,0 & & & & & & & & & \\
\hline & & & & & & & & & & & & & & & & & & 97 & & 0,2 \\
\hline & & & & & & & 1, & & & & & & & & & & & & & \\
\hline & & & & & & & & & & & 0,003 & 1927 & & & & & & 88 & 056 & \\
\hline & & & & & & & & & & & 0, & 1,92 & & & & & 060 & & & 0,2 \\
\hline & & & & & 26,5 & & 1,31 & & 99,33 & 3,02 & 0,007 & & & & & & & & 053 & \\
\hline & & & & & & & & & & & 0,005 & $=$ & & & & & & & & 02 \\
\hline & & & & & & & & & & & & & & & & & & & & \\
\hline & & & & & & & & & & 3,0 & 0,0 & & & & & & & & & \\
\hline & & & & & & & & & & & 0,00 & & & & & & & & 001 & \\
\hline ST. 3 & & & & & & & & & & 3,08 & 0,000 & 1,940 & 1,794 & 0,26 & & & 0,613 & 091 & 058 & $=$ \\
\hline & & & & & & & 1,5 & & & & 000 & & & & & & & & & \\
\hline & & & & & & & & & & & & & & & & & & & & \\
\hline & & & & & & & & & & & & & & & & & & & & \\
\hline & & & & & & & 1,2 & & & 2,9 & 0,007 & & & & & & & & & \\
\hline ST-E & & & & & & & & & & 3,0 & 0,008 & 1,971 & 2,1 & 0,032 & & & 13 & & & \\
\hline & & & & & & & & & & & & & & & & & & & & \\
\hline & & & & & & & 4. & & & & & & & & & & & & & \\
\hline & & & & & & & & & & & & & & & & 88 & 2. & & 166 & \\
\hline & & & 0,0 & & & & & & & & & & & & & 11 & 0,699 & 108 & 167 & \\
\hline & & & & & & & & & & & & & & & & & 1 & 0115 & 157 & \\
\hline
\end{tabular}

TABELA 10 -

Análise química de granadas em metassedimentos dos complexos Riacho Gravatá e Cachoeirinha e Xistos Sertânia, calculados para 12-oxigênios, com todo $\mathrm{Fe}=\mathrm{Fe}^{2+}$ 


\begin{tabular}{|c|c|c|c|c|c|c|c|c|c|c|c|c|c|c|c|c|c|c|c|}
\hline Amostra & Domínio & Litolog. & $\mathrm{SiO} 2$ & $\mathrm{Al} 2 \mathrm{O} 3$ & $\mathrm{FeO}$ & $\mathrm{CaO}$ & $\mathrm{Na2O}$ & $\mathrm{K} 2 \mathrm{O}$ & TOTAL & SI & Al & $\mathrm{Fe}$ & $\mathrm{Ca}$ & $\mathrm{Na}$ & $\bar{K}$ & TCat & $\mathrm{XCA}$ & XNA & $\overline{\mathbf{X K}}$ \\
\hline ST.206.2 & CRG-MP & anfibol. & 68,54 & 21,65 & & 2,04 & 8,59 & 0,09 & 100,91 & 2,949 & 1,098 & 0,000 & 0,094 & 0,717 & 0,005 & 4,863 & 0,115 & 0,879 & 0,006 \\
\hline ST.206.2 & RG-MP & anfibol. & 63,89 & 23,65 & 0,07 & 5,45 & 8,41 & 0,07 & 101,54 & 2,782 & 1,214 & 0,003 & 0,254 & 0,710 & 0,004 & 4,968 & 0,263 & 0,733 & 0,004 \\
\hline ST.305.Eb & CRG-MP & anfibol. & 0,32 & 20,41 & 0,08 & 0,53 & 10,19 & 0,06 & 101,59 & 3,004 & 1,028 & 0,003 & 0,024 & 0,844 & 0,003 & 4,906 & 0,028 & 0,968 & 0,004 \\
\hline ST.305.Ec/b & CRG-MP & anfibol. & 70,63 & 19,56 & 0,07 & 0,17 & 9,83 & 0,05 & 100,31 & 3,044 & 0,994 & 0,003 & 0,008 & 0,821 & 0,003 & 4,872 & 0,009 & 0,987 & 0,003 \\
\hline$S T .30$ & CRG-MP & anfibol. & 70,42 & 20,38 & & 0,50 & 10,11 & 0,07 & 101,48 & 3,008 & 1,026 & 0,000 & 0,023 & 0,837 & 0,004 & 999 & 0,026 & 0,969 & 0,004 \\
\hline ST.312.E & CRG-MP & gr-anfib. & 64,17 & 23,23 & 0,09 & 4,39 & 8,95 & 0,08 & 100,91 & 2,806 & 1,198 & 0,003 & 0,206 & 0,759 & 0,004 & 4,976 & 0,212 & 0,783 & 0,005 \\
\hline$S T .312 . E$ & CRG-MP & gr-anfib. & 63,43 & 23,61 & 0,03 & 5,06 & 8,79 & 0,08 & 101,00 & 2,778 & 1,219 & 0,001 & 0,237 & 0,747 & 0,004 & 4,987 & 0,240 & 0,755 & 0,005 \\
\hline ST. $312 . E$ & CRG-MP & gr-anfib. & 63,06 & 23,82 & 0,09 & 5,19 & 8,56 & 0,09 & 100,81 & 2,768 & 1,233 & 0,003 & 0,244 & 0,729 & 0,005 & 4,982 & 0,250 & 0,745 & 0,005 \\
\hline ST.312.E & CRG-MP & gr-anfib. & 62,73 & 24,23 & 0,10 & 5,80 & 7,91 & 0,06 & 100,83 & 2,753 & 1,253 & 0,004 & 0,273 & 0,673 & 0,003 & 4,959 & 0,287 & 0,709 & 0,004 \\
\hline ST.316.A & CRG-MP & gr-anfib. & 66,90 & 21,81 & 0,08 & 2,67 & 9,30 & 0,01 & 100,77 & 2,904 & 1,116 & 0,003 & 0,124 & 0,783 & 0,001 & 4,930 & 0,137 & 0,863 & 0,001 \\
\hline ST. $316 . \mathrm{A}$ & CRG-MP & gr-anfib. & 68,83 & 20,74 & & 1,04 & 9,84 & 0,00 & 100,45 & 2,977 & 1,057 & 0,000 & 0,048 & 0,825 & 0,000 & 4,907 & 0,055 & 0,945 & 0,000 \\
\hline ST.316.A & CRG-MP & granfib. & 69,12 & 20,68 & 0,09 & 0,98 & 10,29 & 0,08 & 101,24 & 2,974 & 1,049 & 0,003 & 0,045 & 0,858 & 0,004 & 4,933 & 0,050 & 0,945 & 0,005 \\
\hline ST.316.A & CRC & gr-anfib. & 63,46 & 24,17 & 0,24 & 5,19 & 8,30 & 0,07 & & 2,766 & 1,242 & 0,009 & 0,242 & 0,702 & 0,004 & 965 & 0,256 & 0,740 & 0,004 \\
\hline ST. 322 & CRG-MP & anfibol. & 69,35 & 20,25 & 0,29 & 0,50 & 10,63 & 0,06 & 101,08 & 2,989 & 1,029 & 0,010 & 0,023 & 0,888 & 0,003 & 943 & 0,025 & 0,971 & 0,004 \\
\hline ST. $322 \mathrm{~b}$ & CRG-MP & anfibol. & 70,15 & 20,27 & 0,20 & 0,32 & 10,40 & 0,03 & 101,37 & 3,005 & 1,024 & 0,007 & 0,015 & 0,864 & 0,002 & 4,916 & 0,017 & 0,981 & 0,002 \\
\hline ST. $322 \mathrm{C}$ & CRC & anfibol. & 69,46 & 20,54 & 0,23 & 0,57 & 10,15 & 0,06 & 101,01 & 2,989 & 1,042 & 0,008 & 0,026 & 0,847 & 0,003 & 4,915 & 0,030 & 0,966 & 0,004 \\
\hline ST. $338 . \mathrm{B}$ & CRG-MP & gr-anfib. & 65,19 & 22,88 & 0,06 & 4,11 & 8,88 & 0,09 & 101,21 & 2,835 & 1,173 & 0,002 & 0,192 & 0,749 & 0,005 & 4,955 & 0,203 & 0,792 & 0,005 \\
\hline ST. $338 . \mathrm{Bb}$ & CRC & gr-anfib & 67,01 & 22,00 & 0,01 & 2,97 & 9,45 & 0,02 & 46 & 2,893 & 1,120 & 0,000 & 0,137 & 0,791 & 0,001 & 4,943 & 0,148 & 0,851 & 0,001 \\
\hline ST. $338 . B C$ & CRC & gr-anfib. & 68,87 & 20,86 & 0,12 & 1,29 & 9,78 & 0,08 & 1,00 & 2,968 & 1,060 & 0,004 & 0,060 & 0,817 & 0,004 & 4,913 & 0,068 & 0,927 & 0,005 \\
\hline ST. $338 . \mathrm{Cb}$ & $\mathrm{CR}$ & anfibol. & 65,37 & 22,60 & 0,22 & 3,53 & 9,03 & 0,05 & 180 & 2,851 & 1,162 & 0,008 & 0,165 & 0,763 & 0,003 & 4,952 & 0,177 & 0,820 & 0,003 \\
\hline ST. 338 & & anfibol. & 62,16 & 23,37 & 0,10 & 5,10 & 8,62 & 0,10 & 45 & 2,769 & 1,227 & 0,004 & 0,243 & 744 & 0,006 & 993 & 0,245 & 49 & 0,006 \\
\hline ST. $338 . \mathrm{Cc}$ & & ol & 67,88 & 20,74 & 0,13 & 1,27 & 9,60 & 0,05 & 67 & 2,963 & 1,067 & 0,005 & 0,059 & 0,813 & 0,003 & 11. & 0,068 & 0,929 & 0,003 \\
\hline ST. 338.C & CRC & anfibol. & 65,49 & 22,61 & 0,40 & 3,39 & 8,84 & 0,15 & 100,88 & 2,854 & 1,161 & 0,015 & 0,158 & 0,747 & 0,008 & 4,943 & 0,173 & 0,818 & 0,009 \\
\hline ST-S-6.A & C & & 69,13 & 19,76 & 0,15 & 0,14 & 9,34 & 1,94 & 46 & 3,009 & 1,014 & 0,005 & 0,007 & 788 & 0,108 & 932 & 0,007 & 0,873 & 0,119 \\
\hline ST-S- & & anfibol. & 65,02 & 18,61 & 0,19 & 0,0 & 0,25 & 16,06 & & 2,996 & 1,011 & 0,007 & 0,001 & 0,022 & 0,944 & 4,982 & 0,001 & 0,023 & 0,976 \\
\hline ST-S-6.A & CRG-MP & anfibol. & 65,88 & 18,73 & 0,27 & 0,00 & 0,22 & 16,42 & 52. & 2,998 & 1,005 & 0,010 & 0,000 & 0,019 & 0,953 & 4,986 & 0,000 & 0,020 & 0,980 \\
\hline ST-475.Ab & C & $g r$-anfib. & 62,43 & 24,50 & 0,10 & 5,86 & 7,63 & 0,05 & & 2,745 & 1,270 & 0,004 & 0,276 & 50 & 0,003 & 947 & 0,297 & 0,700 & 0,003 \\
\hline ST-475 & & gr & 59,89 & 38 & 0,13 & 7,92 & 6,64 & 0,07 & & 2,640 & 1,371 & 0,005 & 0,374 & 567 & 0,004 & 961 & 0,396 & 600 & 0,004 \\
\hline ST-475.AC & C & gr-anfib & 64,53 & 23,44 & 0,09 & 4,48 & 8,37 & 0,12 & 101,16 & 2,812 & 1,204 & 0,003 & 0,209 & 707 & 0,007 & 4,943 & 0,227 & 0,766 & 0,007 \\
\hline ST-475 & & & 60,66 & 24,82 & 0,09 & 6,2 & 7,70 & 0,13 & & 2,703 & 1,304 & 0,003 & 0,300 & 65. & 0,007 & 82 & 0,308 & 0,684 & 0,008 \\
\hline ST-47 & C & fib & 60,93 & 23,92 & 0,13 & 5,74 & 7,99 & 0,06 & 77 & 2,735 & 1,266 & 0,005 & 0,276 & 695 & 0,003 & 4,981 & 0,283 & 0,713 & 0,004 \\
\hline & & & 62,34 & & 0,00 & 6,01 & 7,43 & 0,09 & & 2,739 & 1,280 & & & & 0,005 & & 0,307 & 87 & 0,005 \\
\hline ST- -47 & & -anfib. & 110 & 5,43 . & 0,05 & 7,21 & 93 & 0,09 & & 2,691 & 1,319 & 0,002 & 0,340 & 91 & 0,005 & 4,947 & 0,363 & 0,632 & 0,005 \\
\hline ST-475.A & CRG-SPS & gr-anfib. & 61,43 & 25,25 & 0,07 & 6,67 & 7,31 & 0,09 & 100,98 & 2,702 & 1,309 & 0,003 & 0,314 & 0,623 & 0,005 & 4,957 & 0,333 & 0,661 & 0,005 \\
\hline ST-530 & & & & & 00 & & 0,70 & 14,75 & & 2,978 & 1,049 & & & & 0,871 & 4,964 & 0,000 & 0,067 & 0,933 \\
\hline ST-530 & $\mathrm{Ps}_{\mathrm{s}}$ & ar & 59,09 & 26,22 & 0 & 8 & 6,59 & 0,1 & 63 & 2,623 & 1,372 & 0,001 & 0,407 & 567 & 0,007 & 978 & 0,415 & 0,578 & 0,007 \\
\hline & & & & & 0,10 & 8,8 & 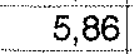 & 0 & & 2,613 & 1,397 & 04 & & & 0,007 & & 0,451 & 441 &, 008 \\
\hline ST-53 & & a & 8,88 & 25,97 & 0,08 & 78 & 58 & 0,1 & 55 & 2,636 & 1,371 & 003 & 0,379 & 11 & 0,007 & 968 & 0,396 & 0,596 & 0,008 \\
\hline ST-5: & & & 58,90 & 26,38 & 0,06 & 8,39 & 6,29 & 0,1 & 0,13 & 2,623 & 1,385 & 02 & 0,400 & 543 & 0,006 & 559 & 0,422 & 0,572 & 0,007 \\
\hline ST-530c & & into & 8,60 & 2630 & 001 & & 6,16 & 01 & 0950 & 2,622 & 1,387 & 0,000 & 0,404 & 534 & 0,006 & 4,954 & 0,428 & 0,566 & 0,006 \\
\hline ST-AC-35.2 & CRG-SPn & $\mathrm{a}$ & 70,16 & 20,15 & 0,07 & 0,28 & 10,56 & 0,08 & 101,30 & 3,008 & 1,018 & 0,003 & 0,013 & 0,878 & 0,004 & 4,924 & 0,014 & 0,981 & 0,005 \\
\hline & & & 67,68 & 20,25 & 0,74 & 0,63 & 10,06 & 0,0 & & 2,971 & 1,048 & 0,027 & 0,030 & 0,856 & 0,002 & 34 & 0,033 & 0,964 & 0,003 \\
\hline ST-AC & $\mathrm{Pn}$ & ol. & 68,63 & 20,82 & 0,16 & 1,26 & 9,98 & 0,0 & 90 & 2,963 & 1,060 & 0,006 & 0,058 & 0,836 & 0,003 & 4,926 & 0,065 & 0,932 & 0,003 \\
\hline $\mathrm{AF}-53 . \mathrm{Fb}$ & CRG-S & ar. & 61,5 & 25,25 & 0,07 & 6,5 & 14 & 0, & 38 & 2,708 & 1,311 & 0,003 & 0,308 & 0,610 & 0,002 & 4,942 & 0,335 & 0,663 & 0,002 \\
\hline$A F-53 . F b$ & & & & & 0,1 & 5,67 & 00 & 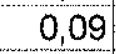 & & 5,100 & 1,262 & 005 & 0,2 & 0,642 & 15 & 37 & 293 & 0,701 & 0,006 \\
\hline AF-53.FC & CRG & gr-anfib. & 62,88 & 24,53 & 0,02 & 6,08 & 7,46 & 0,10 & 101,17 & 2,749 & 1,264 & 0,001 & 0,285 & 0,632 & 0,006 & 4,937 & 0,309 & 0,685 & 0,006 \\
\hline$A F-53 . F C$ & CRG-SM & gr-anfib. & 63,03 & 24,15 & 0,00 & 5,51 & 7,85 & 0,11 & 100,75 & 2,765 & 1,249 & 0,000 & 0,259 & 0,668 & 0,006 & 4,947 & 0,278 & 0,716 & 0,007 \\
\hline
\end{tabular}

TABELA 12

Dados da química mineral de feldspatos em anfibolitos e granada-anfibolitos do Complexo Riacho Gravatá,
calculados com base em 8-oxigênios, com todo $\mathrm{Fe}=\mathrm{Fe}^{2+}$ 


\begin{tabular}{|c|c|c|c|c|c|c|c|c|c|c|c|c|c|c|c|c|c|c|c|c|c|c|c|c|c|c|c|}
\hline & MP & & & & & & & & & & & & & & & & & & & & & & & & & & \\
\hline & MP & & & & & & & & & 1171 & 160 & & & & & & & & & & 200 & & & & & & \\
\hline & & & I: & 48: & & & 13,0 & 26 & 0,54 & 1,73 & 1,54 & & & & & & Sక: & & & & 51314 & & & 28 & 853 & & \\
\hline & & & & 0,58 & 481 & 0,09 & 13,17 & 0.27 & 10,57 & 1180 & 1,51 & 0.55 & 752 & 6,457 & 543 & 1,010 & & 107 & 0,010 & 303 & 503 & 30 & 0,000 & 030 & 848 & & \\
\hline & & & 5 & 0,25 & 130 & 0,03 & 1278 & 020 & 12 oo & 267 & & 0,34 & & 6753 & 247 & 067 & & 184 & OOO3. & 759 & 350 & 112 & 0000 & 023 & 949 & 0028 & 297 \\
\hline & & & & & & & $\begin{array}{l}19,85 \\
10,5\end{array}$ & & & 11,42 & $\begin{array}{l}1,44 \\
1,5\end{array}$ & & & 6,378 & & & & & & $46 !$ & 2,377 & & 0 & 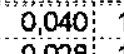 & 4667 & 2,090 & $\begin{array}{l}350 \\
300 \\
320\end{array}$ \\
\hline & & & & & & & & & & & 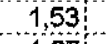 & & & & & & & & & & 2,304 & & & 028 & & & 339 \\
\hline & & & 102 & 资 & 26 & the & $\begin{array}{l}18,79 \\
180\end{array}$ & $\begin{array}{l}0,18 \\
0.18 \\
01\end{array}$ & 673 & $\begin{array}{l}11,35 \\
11,66\end{array}$ & 1,67 & 0,6 & 98,27 & 6402 & 515 & & & ดิ & 00 & 1515 & 176 & & & 年, & 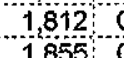 & & \\
\hline & & & & & & $\begin{array}{l}0,0 \\
0\end{array}$ & $\begin{array}{ll}18,85 \\
1037\end{array}$ & : & 6,73 & $\begin{array}{l}11,46 \\
11468\end{array}$ & . 1455 & & 97 & & 515 & & & 1069: &, 00 & 1,515 & 105 & & & 2020 & 1,855 & & 299 \\
\hline & & & 4 & $\begin{array}{l}0,34 \\
579\end{array}$ & 2 & 0,0 & $\begin{array}{l}19,377 \\
18,83\end{array}$ & $\frac{0,30}{0,19}$ & $\begin{array}{l}6,85 \\
712\end{array}$ & 11,462 & $1.4,5$ & $064:$ & 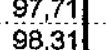 & 6 & 34 & & & $\begin{array}{l}13 \\
87 \\
87\end{array}$ & 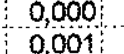 & $1,531:$ & 2,195 & & & 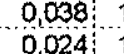 & & 0 & 328: \\
\hline & & & & 0,57 & 4,48 & o: & 18,80 & 0,29 & 7,00 & 11,79 & 1,42 & 0,53 & 97, & $6,445:$ & 555 & 03 & & 79 & 30 & $3 ;$ & $\begin{array}{l}2,262 \\
2,277\end{array}$ & $\begin{array}{l}00 \\
14: 8\end{array}$ & & 3 & (993: & & $\begin{array}{l}0,3737 \\
0,328\end{array}$ \\
\hline & & & 88 & 344 & $86:$ & 0,06 & 94 & 034 & 648 & 1197 & 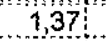 & 0,61 & & 662 & 1,738 & & & 400 & 007 & 4879 & & & & & & & 0,388 \\
\hline & & & & & & & 9,67 & 020 & 5.71 & 1175 & & 0 & & 296 & , 7,704 & & & 0,079 & & & & & & & 01 & & 339 \\
\hline & & & & 64 & & & $0.57 \%$ & 026 & 606 & 1147 & 60 & & 97 & 6,003 &, 597 & & & 0,151 & & 1,378 & 64 & & & & & & \\
\hline & & & 2:44: & 40 & 53 & 006 & 9,5 & 031 & 6,17 & 1145 & 138 & 0,55 & 9688 & 6450 & 1550 & 53 & & 0099 & 0,0 & 397 & 365 & 0,012, & 0 & $8:$ & 65 & 0107 & 9 \\
\hline & & & & 0,40 & 20 & 0,15 & 17,76 & 0.21 & 9,56 & 11,19 & 34 & & & & 381 & 134 & & 0,348 & & 2,095 & & & & & 763 & & 245 \\
\hline & & & & 0,56 & 95 & & 1730 & 026 & 10,24 & 66 & 157 & 0,46 & 0,4 & 64 & 1636 & & & & 172 & 41 & 1,542 & & 045 & 032 & 835 & 0,088 & 359 \\
\hline & & & & 0,47 & 13,16 & 0,06 & 17.98 & 0.25 & 956 & 11,93 & 135 & 0,44 & 9862 & 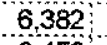 & 1,618 & 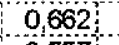 & & 607 & & ,, 094 & 678 & & & 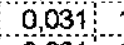 & 879 & 65 & 20 \\
\hline & & & & 0,41 & 1222 & 0,06 & 18,86 & 0.25 & 9,73 & 11,82 & 132 & 0.40 & 99,16 & 6,450 & 1,550 & $0,557 \%$ & & 0,604 & 0.007 & & 666 & & & & & & 0,296 \\
\hline & & & & & 12,95 & 0,09 & 17,40 & $\begin{array}{l}0.24 \\
0.04\end{array}$ & 10,04 & 11,56 & 1,36 & & $\begin{array}{l}98,32 \\
90,32\end{array}$ & $\begin{array}{r}6,425 \\
0\end{array}$ & 1,575 & 0,666 & & & 110: & 96 & 558 & & & & & & 290 \\
\hline & & & & $\begin{array}{l}0,34 \\
030\end{array}$ & $\begin{array}{l}12,35 \\
1371\end{array}$ & 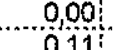 & $\begin{array}{l}18,89 \\
175 ;\end{array}$ & 0 & $\begin{array}{l}946 \\
10346\end{array}$ & $\begin{array}{l}11,61 \\
1160\end{array}$ & $\begin{array}{l}160 \\
147\end{array}$ & 0.39 & 98,86 & $\begin{array}{r}6,44 \\
-6\end{array}$ & $\begin{array}{l}1,536 \\
1.563\end{array}$ & 66: & & sis: & 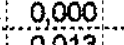 & 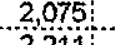 & $776:$ & & 43 & & & & 66 \\
\hline & & & & $\begin{array}{l}0,30 \\
0,41\end{array}$ & $\begin{array}{l}12,71 \\
12,31\end{array}$ & $\begin{array}{l}0,11 \\
0,00\end{array}$ & $\begin{array}{r}77,52 \\
1771\end{array}$ & $\begin{array}{l}0.29 \\
0.29\end{array}$ & $\begin{array}{l}10,24 \\
10,40\end{array}$ & $\begin{array}{l}11,60 \\
11,82\end{array}$ & 1,47 & 0,32 & 99,48 & $\begin{array}{l}6,508 \\
6\end{array}$ & 1,492 & 0,679 & & 476: & $013:$ & $211:$ & 1,590 & 20 & & $36:$ & . & 6: & 307: \\
\hline & & & & 0,45 & 12,57 & 0 & $\begin{array}{c}17,71 \\
17,14\end{array}$ & $\begin{array}{l}0,26 \\
0.26\end{array}$ & $\begin{array}{l}10,40 \\
10,38\end{array}$ & $\begin{array}{l}11,62 \\
11,69\end{array}$ & $\begin{array}{l}1,50 \\
1,56\end{array}$ & $\begin{array}{l}0,40 \\
0,41\end{array}$ & $\begin{array}{r}97,92 \\
97,83\end{array}$ & $\begin{array}{l}6,369 \\
6,400\end{array}$ & $1,1,600$ & $\begin{array}{l}0,512 \\
0,588\end{array}$ & & 848 & 0,001 & $\begin{array}{l}2,288 \\
2,283\end{array}$ & 529 & 0000 & $38:$ & 33 & 840 & 80 & $\begin{array}{l}360: \\
366:\end{array}$ \\
\hline & & & & 0,34 & 1171 & 0,01 & 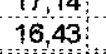 & 0 & $\begin{array}{l}11,04 \\
11,04\end{array}$ & 11,57 & 1,47 & 0.47 & 98,09 & 6.,565 & 4.435 & $\begin{array}{l}0,5899 \\
\end{array}$ & 0,037 & 0 & 0,001 & 2,412 & 502 & 0000 & 0.053 & 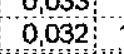 & 1817 & 0.097 & $\begin{array}{l}0,320 \\
0\end{array}$ \\
\hline & & & & 0,84 & 12,47 & 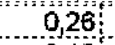 & 16,39 & 028 & $\begin{array}{l}9,27 \\
\quad 127\end{array}$ & 11,51 & $1,83:$ & $n^{2}$ & & $\begin{array}{l}6.559 \\
6.50\end{array}$ & 1441 & 0,756 & & & & 2,065 & 942 & & & & & & \\
\hline & & & & 0,53 & & & 1580 & : & 10,65 & 1155 & 16 & & & 6760 & & & & & & & 76 & & & & 1831 & & 6 \\
\hline & & & & 0,21 & 6,94 & 0 & 14,21 & 0,39 & 12,79 & 1167 & 1,12 & 0,14 & 968 & 7,209 & 0791 & (39) & & & & 279 & 55 & & & & & & o6: \\
\hline & & & & 0 & & . 0,28 & 16,10 & 年 & 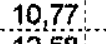 & 43 & 1,62 & 07 & 07 & & 1,178 & & & & & & 758: & & & & & & 35. \\
\hline & & & & $\begin{array}{l}0,23 \\
0,23:\end{array}$ & & 0,07 & $\begin{array}{l}14,966 \\
1601\end{array}$ & & & & 1,15 & & & & 0,821 & & & & & & & & & & & & \\
\hline & & & & $\begin{array}{l}0,53 \\
040\end{array}$ & $\begin{array}{l}8,3 \\
98\end{array}$ & 0 & $\begin{array}{l}16,01 \\
16,09\end{array}$ & $\begin{array}{l}0,39 \\
0.37\end{array}$ & $\begin{array}{l}12,05 \\
1128\end{array}$ & $\begin{array}{l}12,36 \\
11,68\end{array}$ & $\begin{array}{l}1,33 \\
1,45\end{array}$ & $026:$ & $\begin{array}{l}98,17 \\
9855\end{array}$ & $\begin{array}{r}6878 \\
6843\end{array}$ & $\mid \begin{array}{l}122 \\
1157\end{array}$ & $0,0,323$ & & & 003 & & 336 & 21 & & 27 & & & \\
\hline & & & & $\begin{array}{r}0,40 \\
0,56 \\
0.56\end{array}$ & $\begin{array}{r}985 \\
1319\end{array}$ & $\begin{array}{l}0.08 \\
0.01 \\
0.01\end{array}$ & $\begin{array}{l}66,09 \\
19,37\end{array}$ & $\begin{array}{l}0.37 \\
031 \\
031\end{array}$ & \begin{tabular}{l}
1128,28 \\
\hdashline 7,38
\end{tabular} & $\begin{array}{l}11,68 \\
111,75\end{array}$ & $\begin{array}{l}145 \\
153\end{array}$ & $\begin{array}{l}0.2 \\
056\end{array}$ & $\begin{array}{l}.98,59 \\
98,30\end{array}$ & $\begin{array}{c}6883 \\
6530\end{array}$ & $\begin{array}{l}1758 \\
1470 \%\end{array}$ & 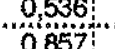 & $\begin{array}{l}0,044 \\
0,063\end{array}$ & on: & $\begin{array}{l}0,032 \\
0,2\end{array}$ & 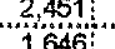 & 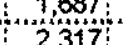 & $\begin{array}{l}0,000 \\
0,000 \\
0,00 \%\end{array}$ & & & $25:$ & 104 & 306 \\
\hline & & & & & & & & & $6,40:$ & & & & & & 1742 & & & & & & & & & & & & \\
\hline & & & & & & & & & & & & & & & 9 & & & & & & & & & & & & \\
\hline & & & & 0,58 & & 00 & $20,58=$ & 0,2 & 7,55 & 12,20 & 1,28 & 0,59 & 98 & 55 & 1,445 & 0,659 & $65:$ & & & 1,685 & 2,360 & & 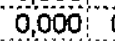 & 20: & 1,957 & & $0,349:$ \\
\hline & & & & 0,3 & & & 1755 & 0.28 & 698 & 1101 & 206 & 0,42 & & 66 & 1,704 & 6 & & & & 1,5 & 082 & & & & & & \\
\hline & & & & & & & 18,59 & 0,30 & 735 & & 2,07 & 0.51 & & & 23 & & & & & & & & & & & & \\
\hline & & & & 0.55 & & & $\begin{array}{l}18,57 \\
.04\end{array}$ & $\begin{array}{c}0,29 \\
0\end{array}$ & 733 & $i_{\mathrm{kg} g}$ & 2,00 & 05 & 97 & 49 & 1851 & & & & & & & & & & & & \\
\hline & & & & & & & 11 & 6 & 82 & & 0,27 & 0,09 & 98 & 0 & & & & & & & 68 & & & & & & \\
\hline & & & & & & & & & & & 355. & & & & & & & & & & & & & & & & \\
\hline & & & & & & 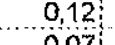 & 11 & 6 & & & 31 & & & & 72 & & & & & & & & & & & & \\
\hline & & & & 0.08 & 2,7 & 0 & $\begin{array}{r}0,92 \\
1125\end{array}$ & 0.29 & 1667 & $\begin{array}{l}13,10 \\
12799\end{array}$ & $0.0,31$ & 016 & $\begin{array}{l}99,0 \\
98,3\end{array}$ & $\begin{array}{l}7,651 \\
7652\end{array}$ & $\begin{array}{l}0,349 \\
0.379\end{array}$ & & & & & & & & & & & & \\
\hline & & & & $\begin{array}{l}0.42 \\
0.42\end{array}$ & & & & $\begin{array}{l}0,0,09 \\
0,09\end{array}$ & $\begin{array}{l}9,6 \\
9,65\end{array}$ & & 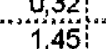 & 0,016 & & 6254 & $176 !$ & & & & & & & & & & & & \\
\hline & & & & & & & & & & & & & & & & & & & & & & & & & & & \\
\hline & & & & & & & & & & & & & & & & & & & & & & & & & & & \\
\hline & & & & & & & & & & & 4 & & & & 1506 & & & & & & & & & & & & \\
\hline & & & & & & & & & & & & & & & $\begin{array}{l}1,501 \\
1,583\end{array}$ & & & & & & & & & & & & \\
\hline & & & & & & & & & & & 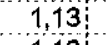 & & & & 1,583 & & & & & & & & & & & & \\
\hline & & & & & & & 15 & & 107 & 0 & 1,13 & 1,29 & & & (2) & & & & & & & 0 & & & & & \\
\hline & & & & 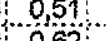 & & 等 & .15 & $9:$ & $\begin{array}{l}12,24 \\
11 ; 0\end{array}$ & $i$ & 年, & $\begin{array}{l}0,90 \\
1700\end{array}$ & & Uí & 1398 & 0 & . & & & 2,643 & 002 & on & & & 200 & & \\
\hline & & & & & & & & & & & $\frac{1.14 \mathrm{i}}{177 !}$ & & & & & & & & & & & & & & & & \\
\hline & & & & : & & 0, & 15 & 6 & & & 182 & 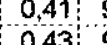 & & $\begin{array}{l}6 \\
60 \\
0\end{array}$ & $24:$ & $6 !$ & & & & & 155 & & & & & & \\
\hline & & & & 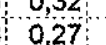 & & & 15 & 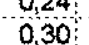 & & & 1,84 & & 98 & & : & & & & & & & & & & & & \\
\hline & & & & & & & & & & & . & & & & in. & & & & & & & & & & & & \\
\hline & & & & & & & & & & & $\ldots=$ & & & & 4197 & & & & & & & & & & & & \\
\hline & & & & & & & & & & & 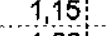 & & & & & & & & & & & & & & & & \\
\hline & & & & & & 0 & 15 & 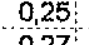 & & & 1,66 & & & & 2 & & & & & & & & & & & & \\
\hline & & & & & & 0 & .15 & 0,2 & & & & & & & 0: & & & & & & & & & & & & \\
\hline & & & & & & & 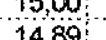 & $\hat{t}$ & & & $5 \%$ & & & & 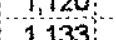 & & & & & & & & & & & & \\
\hline & & & & & & & & & & & 1,31: & & & & 1,3 & & 0 & & & & & & & & & & \\
\hline & & & & 0 & $\theta_{1}$ & & & & & & 1,05 & & & & 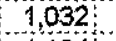 & & & & & 2,6 & 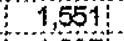 & & & & 864 & & \\
\hline & & & & & 9 & & & 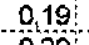 & 12,77 & 11. & 1,18 & & & 6,816 & 1184 & & & & & & & & & & & & \\
\hline & & & & & & & & & & & $\begin{array}{l}1,40 \\
1.40\end{array}$ & & & & & & & & & & & & & & & & \\
\hline & & & & & & & & 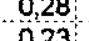 & & & $\begin{array}{l}1,15 \\
1,10\end{array}$ & & & & $1,06 /$ & & & & & & & & & & & & \\
\hline & & & & & & & & & & & & & & & & & & & & & & & & & & & \\
\hline & & & & & & & & & & & & & & & & & & & & & & & & & & & \\
\hline & & & & & & & & & & & $2,03:$ & & & & 19001: & & & & & & & & & & & & \\
\hline & & & & & & & & & & & 1,94 & & & & ; & & & & & & & & & & & & \\
\hline & & & & & & 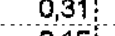 & 16. & 0,23 & 13,07 & & 1.9 & & 97,9 & & 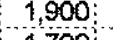 & & & & & & & & & & & & \\
\hline & & $g r=$ & $\begin{array}{l}42,7 \\
4\end{array}$ & & 集, 83 & 0,1 & 5,93 & 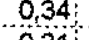 & 售, & 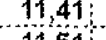 & $1,9 ?$ & & & 209 & 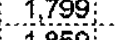 & & & & & & & & & & & & \\
\hline & & & & & & & & & & & & & & & & & & & & & & & & & & & \\
\hline & & & & & & & & & & & & & & & & & & & & & & & & & & & \\
\hline
\end{tabular}

TABELA 13 -

Análise química de anfibólios em metabásicas do em 23-oxigênios, Gravatá, calculados 


\begin{tabular}{|c|c|c|c|c|c|c|c|c|c|c|c|c|c|c|c|c|c|c|c|c|}
\hline Amostra & omínio & 102 & $\mathrm{TiO}_{2}$ & 20 & 20 & no & 90 & 20 & & & & & $\mathrm{Fe}$ & $\mathrm{Mn}$ & $\mathrm{Mg}$ & $\mathrm{Ca}$ & $\overline{\mathrm{XFE}}$ & XMN & $\mathrm{XMG}$ & $\overline{X C A}$ \\
\hline ST- $-475 A B$ & & 9,73 & 0,03 & 21,98 & 23,32 & 0,55 & 9,37 & 6,06 & 4 & 3,002 & & 1,95 & 1,474 & 0,035 & 1,055 & 0,491 & 0,482 & 0,012 & 0,345 & 01 \\
\hline & & & & & & & & & & & & & 1503 & 0047 & 016 & 498 & 491 & & 332 & 16 \\
\hline & & & & & & & & & & & & & & & 965 & & & & 314 & \\
\hline & & & & & & & & & & & & & & 0,054 & 953 & 483 & 0,510 & & 13 & 15 \\
\hline & & & & & & & 8 & & & & & & & & & & 499 & & & 16 \\
\hline ST-532 & & & & 44 & 28,10 & & 4,46 & & & & & 2,007 & 004 & 092 & 518 & 583 & 0,606 & & 171 & 19 \\
\hline & & & & & & & & & & & & 1,989 & & & 214 & & 622 & & 71 & \\
\hline & & & & & & & & & & & & & & & & & & & 57. & 235 \\
\hline & & & & & & & & & & & & & & & & & & & & 23 \\
\hline & & & & & & & & & & & & & & & & & & & & 21 \\
\hline & & & & & & & & & & & & & & & & & & & & 250 \\
\hline Af-5 & & & & & & & & & & & & & 44 & 4 & 11 & 98 & 596 & $3 r$ & 64 &, 25 \\
\hline & & & & & & & & & & & & & & & 59 & & 335 & 36 & 53 & \\
\hline & & & & & & & & & & & & & & & & & 317 & & 35 & 28 \\
\hline & & & & & & & & & & & & & & & & & 615 & & 28 &, 28 \\
\hline & & & & & & & & & & 01 & & 2 & & & & & 13 & & & 20 \\
\hline & & & & & & & & & & & & & & & & & & & & 29 \\
\hline & & & & & & & & & & & & & & & 17 & & & & & 29 \\
\hline & & & & & & & & & & & & & & & & & & & & 0,30 \\
\hline & & & & & & & & & & & & & & 5 & & & 04 & & & 30 \\
\hline & & & & & & & & & & & & & & & & & & & &, 30 \\
\hline ST. 3 & & & & & & & & & & 58 & 5 & 9 & 09 & 515 & 0,061 & 0,943 & 0,498 & 170 & .020 & 0,311 \\
\hline & & & & & & & & & & $=$ & 07 & $=1$ & 7 & & 0,121 & & & & &, 271 \\
\hline & & & & & & & & & & & & & & & & & & & & 3 \\
\hline & & & & & & & & & & & & & & & & & 636 & & 45 & 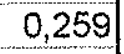 \\
\hline & & & & 51 & 28,08 & 1 & 1,17 & & 13 & 855 & & & & & & & 0,640 & & 17 & 0,26 \\
\hline & & & & & & & & & & & & & & & & & 0,571 & 27. & & 0,26 \\
\hline & & & & & & & & & & & & & & & & 801 & , & & & \\
\hline ST.338.BC & CRG-MP & 38,63 & 0,32 & $20, / 2$ & 24,111 & , s, s, & 0,00 & , & 101,40 & (1) & & & & 0,49 & 07 & & 535 & 165 & 0,02 & 0.2 \\
\hline
\end{tabular}

TABELA 14 -

Análise química de granadas em granada-anfibolitos

do Complexo Riacho Gravatá, calculados com base em 12-oxigênios, com todo $\mathrm{Fe}=\mathrm{Fe}^{2+}$ 


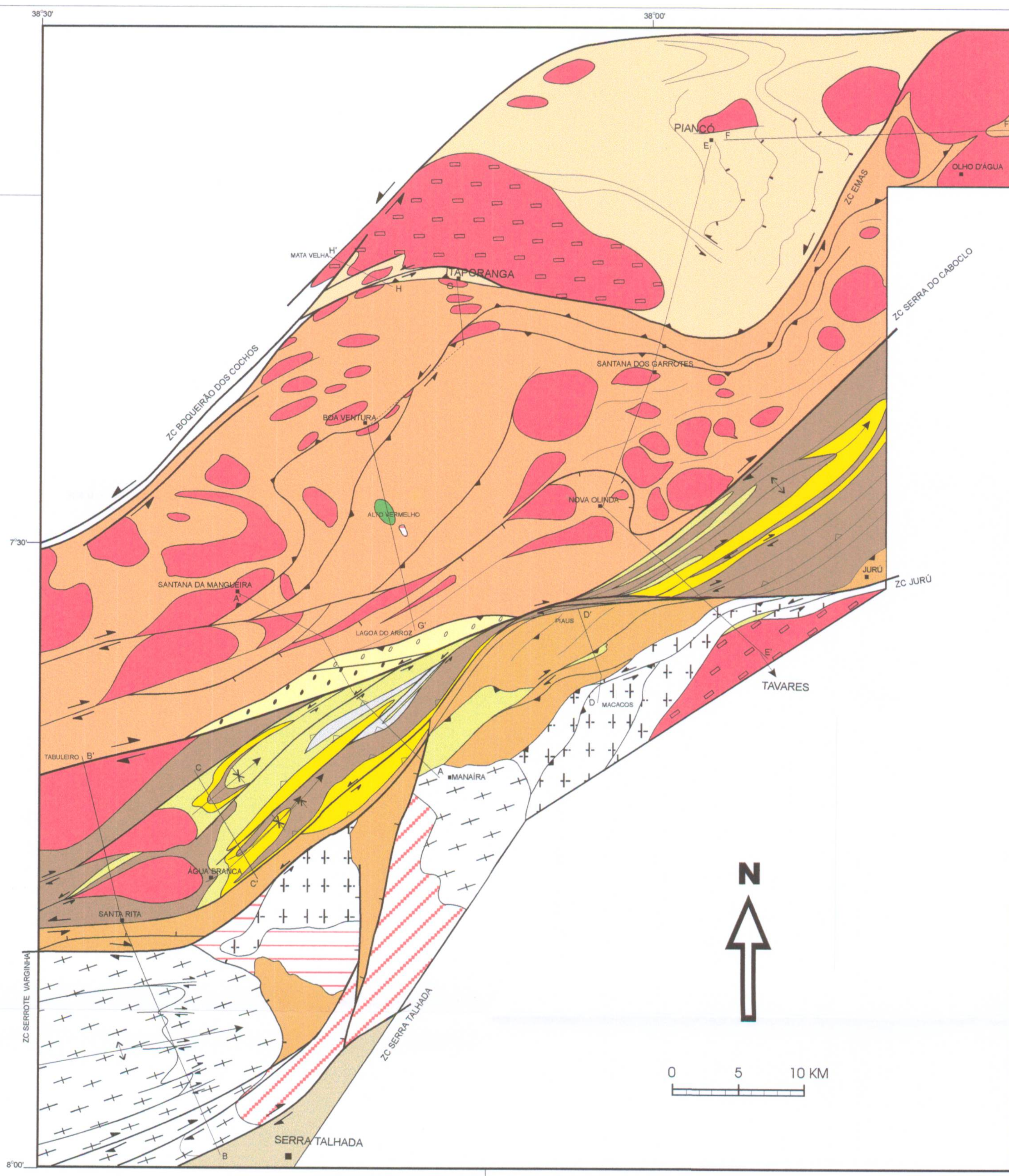

MAPA GEOLÓGIC̄O SIMPLIFICADO

DA FAIXA PIANCÓ-ALTO BRÍGIDA NA ÁREA DE SERRA TALHADA-PIANCÓ-ITAPORANGA

\section{LEGENDA}

GRANITOIIDES BRASILIANOS

$\square_{\text {TIPO CONCEIÇ̃ó }} \underset{\text { TIPO ITAPORANGA }}{\square}$

SEQUENCIA SERRA DO OLHO D'ÁGUA

.7

$$
\text { LITOFÁCIES ARENOSO E PELLITICO-ARENOSO }
$$

COMPLEXO CACHOEIRINHA

SEQUENCIA SANTANA DOS GARROTES SEQUENCIA PIANCO

COMPLEXO RIACHO GRAVATA

XISTOS SERTÂNIA

$\square+\square$

GNAISSES CARIRIS VELHOS

$+$

COMPLEXO SERRA TALHADA

$+$

\section{SIMBOLOGIA}

7. zona de cisalhamento transcorrente F3

Falha normal F2

FALHA NORMALFS

EMPURRÃO $F$

A' LOCALIZAÇÃO DOS PERFIS (ANEXO2)

ARAÇO DA FOLLAÇÃO PRINCIPAL

$\hat{\imath}$ ANTIFORMAF3

$x \rightarrow$ SINFORMA F3

SHEILA BITTAR -TESE DOUTORADO - IG/USP - 1998 ORIENTADOR: Prof. Dr.MARIO DA COSTA CAMPOS NETO 


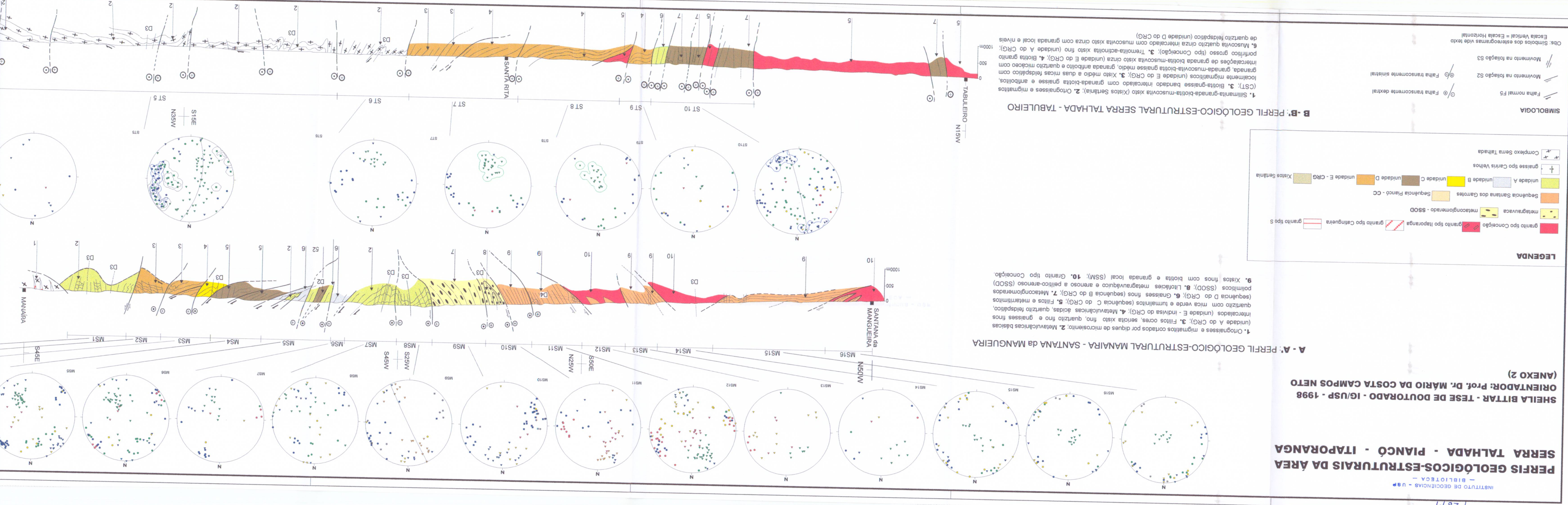




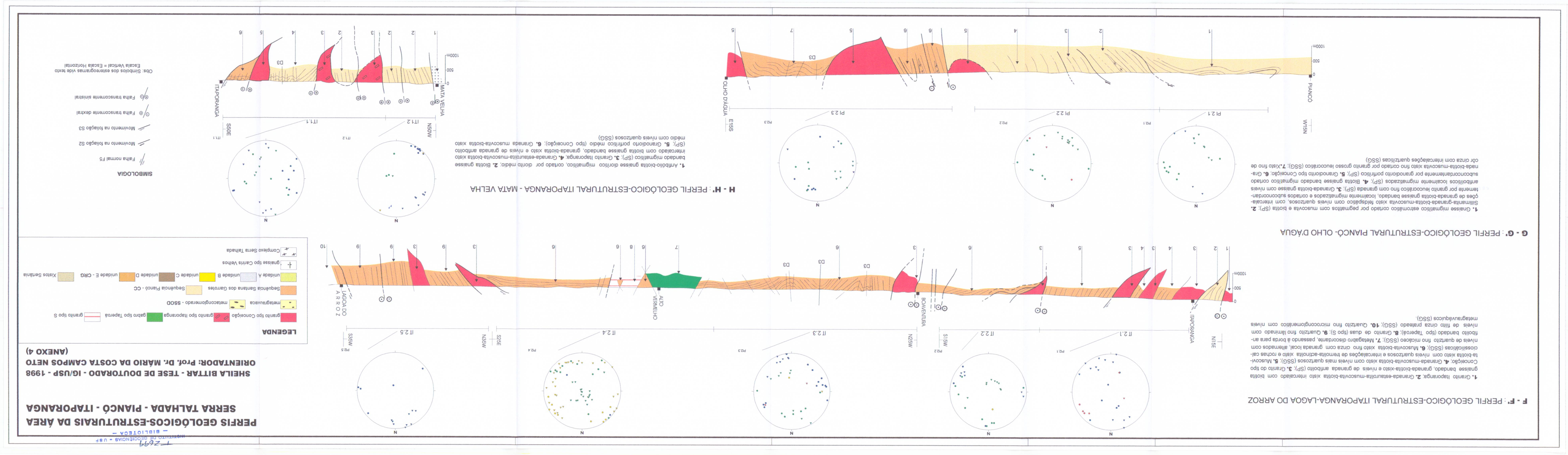


C.C. PERFL GEOLÓGICO-ESTRUTURAL AREA DE AGUA BRANCA

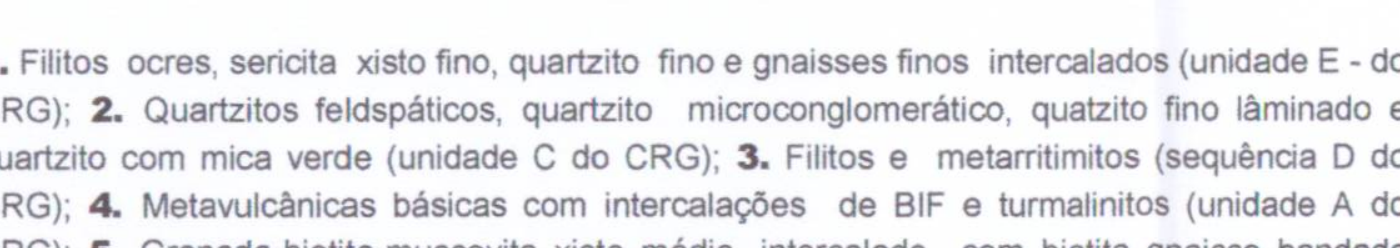

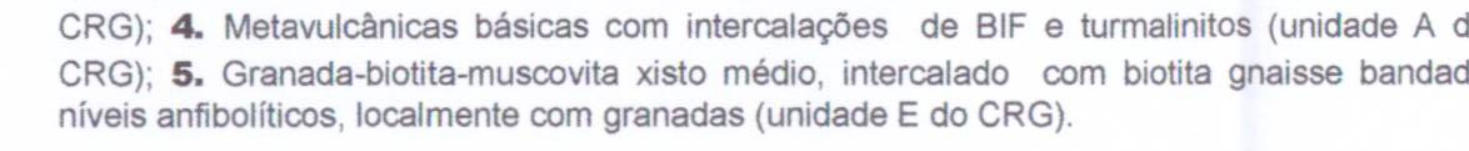

E- E: PERFIL GEOLOGGICO-ESTRUTURAL PAANCO- TAVARES

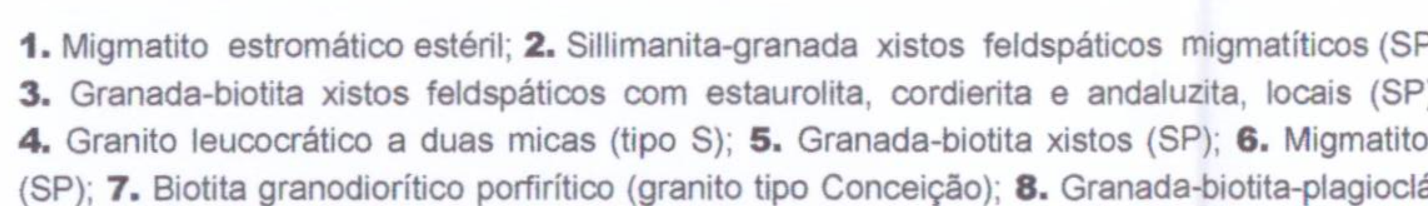

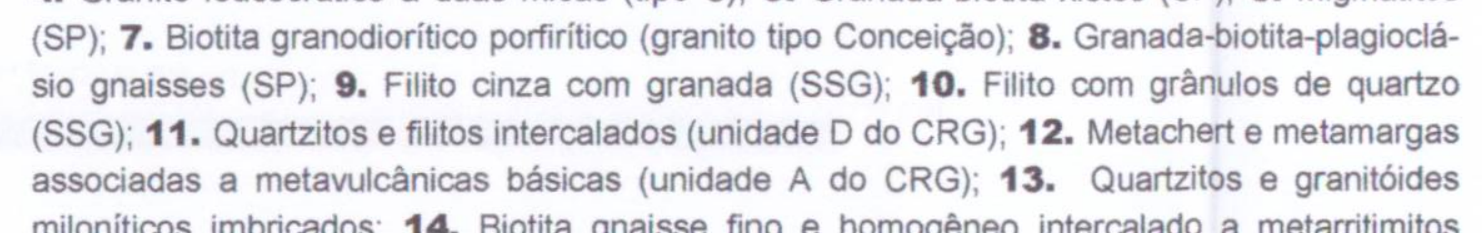

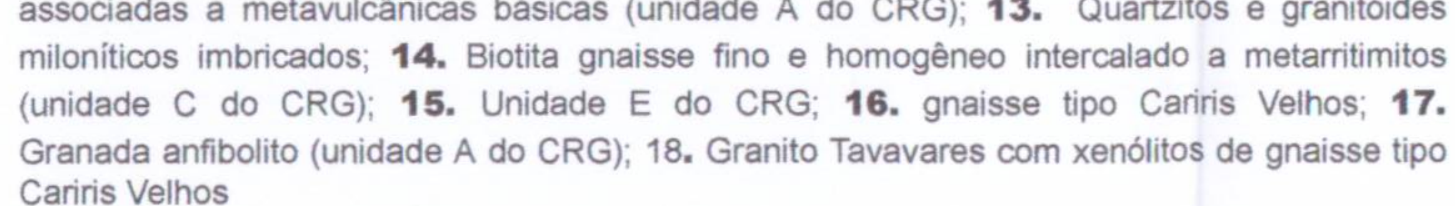

\section{$-9$}

-D: PERFLL GEOLOGGIO-ESTRUTURAL MACACOS - PAaUS

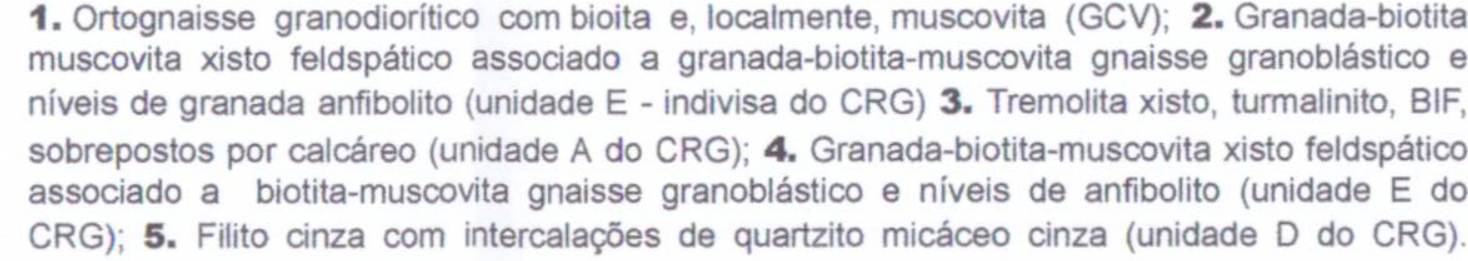

.

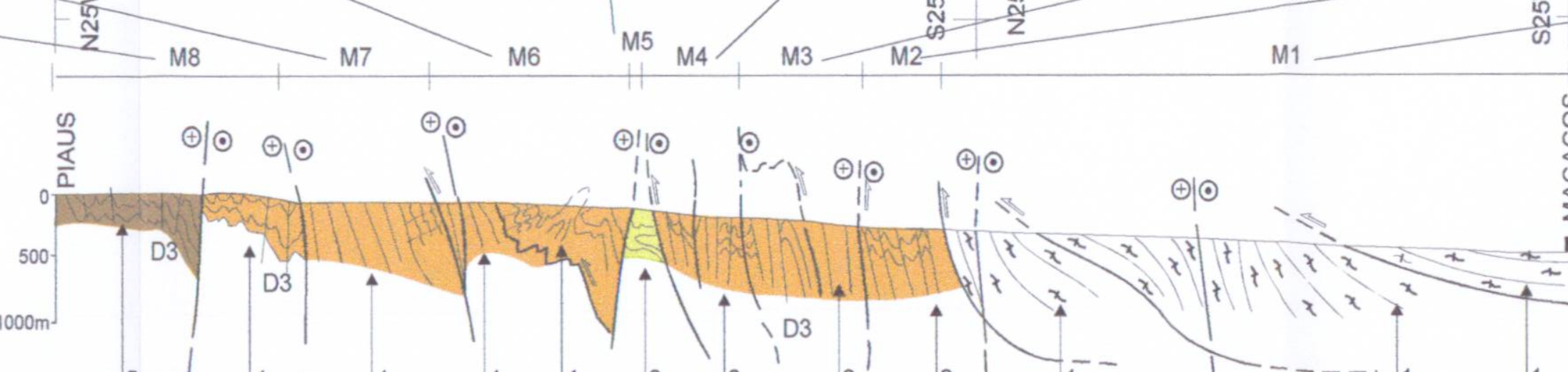

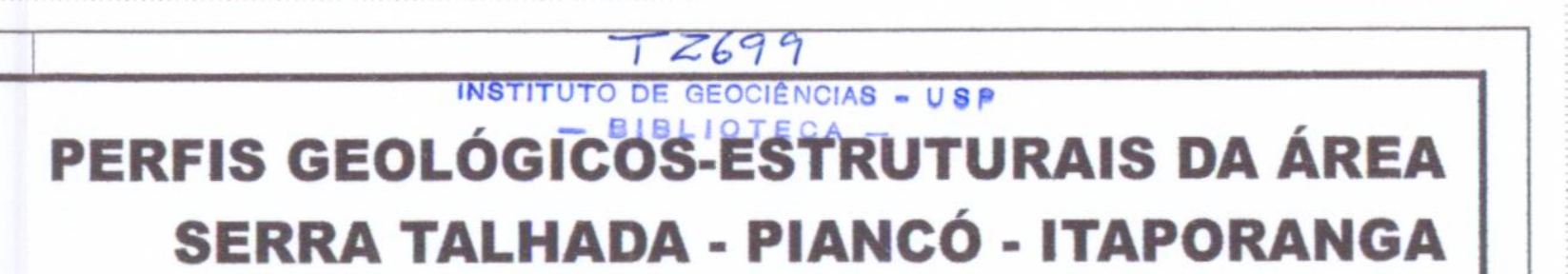

SHELA BITTAR - TESE DE DOUTORADO - IGUSP - 1998
ORIENTADOR: Prof. Dr. MARIO DA COSTA CAMPOS NETO
AMNEXO 3 $-$

in 6 tonter

smbolocin 